\title{
Verandering en verschuiving : bijdrage tot de revalidatie van patienten met amputaties van de onderste extremiteiten op basis van een na-onderzoek over de periode juni 1972-juni 1977
}

Citation for published version (APA):

Poulssen, M. G. N. (1979). Verandering en verschuiving : bijdrage tot de revalidatie van patienten met amputaties van de onderste extremiteiten op basis van een na-onderzoek over de periode juni 1972-juni 1977. [Doctoral Thesis, Maastricht University]. Rijksuniversiteit Maastricht.

https://doi.org/10.26481/dis.19791207mp

Document status and date:

Published: 01/01/1979

DOI:

10.26481/dis.19791207mp

Document Version:

Publisher's PDF, also known as Version of record

Please check the document version of this publication:

- A submitted manuscript is the version of the article upon submission and before peer-review. There can be important differences between the submitted version and the official published version of record. People interested in the research are advised to contact the author for the final version of the publication, or visit the DOI to the publisher's website.

- The final author version and the galley proof are versions of the publication after peer review.

- The final published version features the final layout of the paper including the volume, issue and page numbers.

Link to publication

\footnotetext{
General rights rights.

- You may freely distribute the URL identifying the publication in the public portal. please follow below link for the End User Agreement:

www.umlib.nl/taverne-license

Take down policy

If you believe that this document breaches copyright please contact us at:

repository@maastrichtuniversity.nl

providing details and we will investigate your claim.
}

Copyright and moral rights for the publications made accessible in the public portal are retained by the authors and/or other copyright owners and it is a condition of accessing publications that users recognise and abide by the legal requirements associated with these

- Users may download and print one copy of any publication from the public portal for the purpose of private study or research.

- You may not further distribute the material or use it for any profit-making activity or commercial gain

If the publication is distributed under the terms of Article 25fa of the Dutch Copyright Act, indicated by the "Taverne" license above, 


\section{Verandering en verschuiving}

Bijdrage tot de revalidatie van patiënten met amputaties van de onderste extremiteiten op basis van een na-onderzoek over de periode juni 1972 - juni 1977 
$\begin{array}{ccccc} & \therefore & \ddots & \ddots & \\ & \ddots & \ddots & \ddots & \\ & \therefore & & \ddots & \ddots\end{array}$ 


\title{
VERANDERING EN VERSCHUIVING
}

Bijdrage tot de revalidatie van patiënten met amputaties van de onderste extremiteiten op basis van een na-onderzoek over de periode juni 1972 - juni 1977.

\section{ACADEMISCH PROEFSCHRIFT}

TER VERKRIJGING VAN DE GRAAD VAN DOCTOR IN DE GENEESKUNDE AAN DE RIJKSUNIVERSITEIT LIMBURG, OP GEZAG VAN DE RECTOR MAGNIFICUS DR. W.H.F.W. WIJNEN, HOOGLERAAR IN DE FACULTEIT DER GENEESKUNDE, VOLGENS BESLUIT VAN HET COLLEGE DER DEKANEN IN HET OPENBAAR TE VERDEDIGEN OP VRIJDAG 7 DECEMBER 1979 DES NAMIDDAGS OM 4 UUR PRECIES, IN DE AULA DER UNIVERSITEIT.

\author{
door \\ M.G.N. Poulssen \\ geboren te Geleen.
}


PROMOTOR: PROF. DR. H.A.J. LEMMENS

CO-PROMOTOR: PROF. DR. J.J.C.B. BREMER

REFERENTEN: PROF. DR. J.M. GREEP

PROF. DR. E. MARQUARDT

DR. J.A. PINCKAERS 
"Amputation is an easy escape from a difficult problem for everyone, except the patient". Gillis.

an mijn kinderen

aran mijn vroum

aun drie bejadrden 


\section{VOORWOORD}

Het beëindigen van intensieve arbeid, welke het schrijven van een dissertatie doorgaans blijkt te zijn, gaat gepaard met het schrijven van een voorwoord. Terecht wordt dit geen slotwoord genoemd, omdat zulks de veronderstelling zou wettigen dat men van de auteur niets meer mag verwachten na datgene, wat men de afsluiting van de academische studie pleegt te noemen.

Juist op het terrein van de revalidatie-geneeskunde zal in Nederland nog veel fundamenteel onderzoek verricht moeten worden, wil deze nog vrij jonge vorm van specialisatie haar plaats kunnen innemen tussen de andere specialismen.

Daarom is het des te meer verheugend dat vertegenwoordigers van andere disciplines, te weten chirurgie, orthopaedie en psychologie, bereid waren deze dissertatie te willen begeleiden.

Hooggeleerde Lemmens, in 1973 was $U$ spontaan bereid op te willen treden als promotor bij de organisatie van de revalidatie van geamputeerden in de regio. Het vertrouwen in de bereidheid van de Limburgse chirurgen en orthopaeden om hieraan hun medewerking te willen verlenen bleek niet ongegrond. Uw betrokkenheid als algemeen chirurg bij de revalidatie-problematiek kan men ook constateren uit het gegeven dat $U$ regelmatig er bij mij op aangedrongen hebt een dissertatie te schrijven, handelend over de revalidatie van geamputeerden. Revalidatie van geamputeerden, maar dan als een regionale zaak in samenwerking met alle ziekenhuizen om tot een structurering te komen, die, gezien de conclusies van het proefschrift, zeer urgent was. Dit waren voldoende argumenten om u en de Rijksuniversiteit Limburg te kiezen, wanneer deze andere structuur in een klein gebied van de gezondheidszorg onderwerp van een dissertatie zou zijn.

Hooggeleerde Bremer, juist om de psychische nood te onderstrepen, waarin de mens na een beenamputatie kan komen te verkeren, werd $U$ aanvankelijk uitgenodigd om als referent te fungeren. Uw voorstel om als co-promotor op te treden, waardoor toch $U w$ taak een belangrijke uitbreiding zou krijgen, bevestigde nogmaals Uw belangstelling en aandacht voor de werkzaamheden van het R.C.H. Voor de wijze, waarop U zich van Uw taak gekweten hebt, ben ik U zeer erkentelijk.

Hooggeleerde Greep, Uw inzet bij het tot stand komen van de medische faculteit, alsmede Uw betrokkenheid bij de artsenopleiding nieuwe stijl te Maastricht zijn bekend. Het zoeken naar nieuwe wegen voor regionale samenwerking, waarbij platgetreden paden bij voorkeur vermeden worden, is eveneens mijn „basisphilosophie" bij de zorg voor geamputeerden. Dit kan evenzeer het uitgangspunt zijn, waar de Rijksuniversiteit Limburg en de Lucas-Stichting elkaar kunnen vinden, wanneer beide instellingen tezamen een greep trachten te krijgen op de revalidatie in de regio.

Hooggeleerde Marquardt, $U$ bent in West-Europa een der voortrekkers op het pad van de revalidatie van geamputeerden. Uw toezegging om, naast Uw drukke werkzaamheden in en buiten Heidelberg, als referent op te willen treden is voor mij het bewijs dat ook „Hoensbroeck" de juiste weg gekozen heeft bij de behandeling van beengeamputeerden. 
Zeergeleerde Pinckaers, het verzoek van de promotor aan $U$ gericht on ook plaats te nemen in de onderzoekscommissie, werd spontaan gehonoreerd. Uw plaats als referent wil ik zeer nadrukkelijk zien als een hommage aan de samenwerking tussen de Limburgse chirurgen en orthopaeden en het amputatie-team van het R.C.H. Dat specialisten in een algemeen ziekenhuis weinig belangstelling zouden hebben voor het revalidatie-gebeuren, werd de afgelopen jaren duidelijk gelogenstraft.

Bij de bewerking van dit proefschrift heb ik de medewerking gevraagd van de revalidatie-artsen te Riele, Janssen en Pons, die vanuit hun optiek en functie respectievelijk als dirigerend geneesheer van het R.C.H., revalidatie-arts van het De Weverziekenhuis en revalidatie-arts van het R.C.H. mij waardevolle adviezen gaven.

Bijzonder erkentelijk ben ik collega Berghauser Pont, die de gegevens van de patiënten, vermeld in hoofdstuk $V$., mede bewerkte en daarmee de, althans in mijn ogen, saaie arbeid verrichtte, die uiteindelijk wel tot evidente conclusies leidde. Hugo, jouw aandeel is belangrijk geweest, want jij was, naast anderen, de laatste prikkel om het vage voornemen een dissertatie te schrijven om te zetten in een nu gerealiseerd proefschrift.

Een bijzonder woord van waardering is ook op zijn plaats voor Ir. Bougie, Hoofd van het centrum revalidatie-techniek „Hoensbroeck”, die mijn vragen naar de toekomst met betrekking tot geamputeerden omzette in grafische beelden, geen drogbeelden maar te verwachten harde realiteit.

Het amputatie-team van het R.C.H., alsmede de verpleegkundigen en ziekenverzorgenden van afdeling II, hebben de resultaten mogelijk gemaakt, waarvan ik de beschrijver mocht zijn. Dit academisch proefschrift, een verdediging waardig gekeurd, is mede het resultaat van hun bewonderenswaardige inzet.

De Lucas-Stichting voor Revalidatie, met haar directeur C. de Ruijter, stelde mij niet alleen vanaf 1972 in staat mijn visie op de revalidatie en haar plaats binnen de gezondheidszorg van Limburg uit te voeren, ook het realiseren van dit proefschrift maakte zij mogelijk.

Tenslotte heb ik oprecht bewondering voor mijn secretaresse, Mevrouw 1. van Malsen, die een inzet toonde, welke ik, naast haar drukke dagtaak, niet voor mogelijk had gehouden. Haar komt de eer toe van een typografisch magnifiek verzorgd manuscript. 


\section{INHOUDSOPGAVE}

Inleiding.

Hoofdstuk I: Lucasstichting voor Revalidatie. 13

II Revalidatie Centrum "Hoensbroeck". (R.C.H.) 17

I2 Audliologisch Centrum "Hoensbroeck". (A.C.H.) 21

13 Logopaedisch Centrum "Hoensbroeck". (L.C.H.) 22

I 4 Centrum voor Revalidatie- Techniek "Hoensbroeck". (R.T.H.)

I 5 B.I.O.S. Centrum "Hoensbroeck". (Bevordering Integratie Ontspanning Sport) 25

I 6 Revalidatie Academie "Hoensbroeck". (R.A.H.) 26

17 V.I.A. (Voorbereiding Inschakeling Arbeidsproces) 27

I 8 Centrum voor Beroepsopleidingen "Hoensbroeck". 28 (C.B.H).

Hoofdstuk II: Behandeling van geamputeerden, vroeger en nu.

Hoofdstuk III: Voor-en nazorg van geamputeerden.

Hoofdstuk IV: Mens-Machine-Milieusysteem. 58

IV 1 De problemen rond de bejaarde mens. 62

IV 2 De problemen rond de volwassene.

IV 3 De problemen rond het kind en de adolescent. 76

$\begin{array}{llll}\text { Hoofdstuk } & \text { V: Eigen Onderzoek. } & 89\end{array}$

V I Herkomst van de onderzoekspopulatie. $\quad 89$

V 2 Indicatie tot amputatie. $\quad 92$

V 3 Verdeling naar amputatieniveau. 94

V 4 Amputatieleeftijd onderverdeeld naar geslacht en amputatieniveau. $\quad 95$

V 5 Complicerende factoren. 96

V 6 Tijdsduur tussen amputatie, opname in en ontslag uit het R.C.H. $\quad 97$

V 7 Onderbeengeamputeerden. 99

V 8 Prothesekeuze bij de onderbeengeamputeerden. 102

V 9 Opnameduur ter revalidatie van onderbeengeamputeerden.

V 10 De resultaten van prothesevoorziening en looptraining. 104 
V 11 Bovenbeengeamputeerden. 106

V 12 Prothesekeuze bij de bovenbeengeamputeerden. 106

V 13 De resultaten van prothesevoorziening en looptraining. 109

V 14 De activiteiten van de maatschappelijk werkende. 111

V 15 De activiteiten van de psycholoog. 114

V 16 De activiteiten van de ergotherapeut. 116

$\begin{array}{ll}\mathrm{V} 17 & \text { Uiteindelijke resultaten. } \\ \end{array}$

$\begin{array}{lll}\text { Hoofdstuk VI: Voet- en voetwortelamputaties. } & 126\end{array}$

Hoofdstuk VII: De knie-exarticulatie.

Hoofdstuk VIII: De toekomst, drogbeeld of realiteit? 179

$\begin{array}{ll}\text { Epiloog. } & 197\end{array}$

$\begin{array}{ll}\text { Samenvatting. } & 215\end{array}$ 


\section{Inleiding.}

, Rehabilitation, as applied to disability, is the combined and coordinated use of medical, social, educational and vocational measures for training and retraining the individual to the highest possible level of functional ability." Dit is de definitie van het begrip revalidatie zoals omschreven door de World Health Organisation in november 1968 te Genève.

In de periode van juni 1972 tot juni 1977 werden in het Revalidatie Centrum "Hoensbroeck" 125 patiënten opgenomen voor eerste prothesevoorziening en revalidatie, nadat in een algemeen ziekenhuis éen of meer beenamputaties waren verricht.

Het doel van deze studie is om aan de hand van de ervaringen met deze 125 patiënten te komen tot een model van verantwoorde revalidatie van deze patiëntencategorie.

De beantwoording van de vraag of de revalidatie van deze patiënten verantwoond heeft plaatsgevonden werd getoetst aan de volgende 2 punten:

a. Was deze revalidatie van geamputeenden in overeenstemming met de definitie van revalidatie zoals door de W.H.O. omschreven?

b. Droeg een organisatiestructuur zoals die zich ontwikkelde binnen de "Lucasstichting voor Revalidatie " bij tot een optimalle revalidatie van geamputeerden?

Indien men uit voorliggende studie de conclusie zou kunnen trekken dat op beide vragen bevestigend geantwoord kan worden, dan dringt zich tevens de conclusie naar voren dat de beide onder $a$. en b. genoemde factoren niet los van elkaar mogen worden gezien. Het zou uiteraard te ver gaan om te beweren dat revalidatie van geamputeerden volgens de bedoelingen, neergelegd in de W.H.O.-definitie alleen maar mogelijk is in een organisatiestructuur, zoals deze binnen de ..Lucasstichting voor Revalidatie" wordt geboden.

De werkzaamheden van deze stichting beperken zich immers niet tot de revalidatie van patiënten met beenamputaties. Wel tracht de ,Lucusstich- 


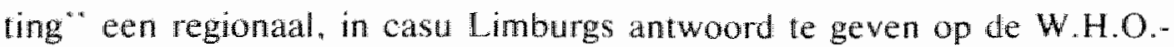
definitie van het begrip revalidatie. Binnen het kader van dit onderzoek is dan ook een algemene beschrijwing van de ,Lucasstichting voor Revalidatie" onmisbaar. Immers, de resultaten, behaald bij de revalidatie van geamputeerden, staan in directe relatie met de mogelijkheden die binnen een organisatiestructuur als die van de ,Lucasstichting voor Revalidatie" geboden worden. Evaluatie van die resultaten voert dan ook tot een beschouwing van de mogelijkheden die binnen zulk een structuur aanwezig zijn.

De tendens lijkt aanwezig dat het aantal geamputeerden in de komende jaren nog zal toenemen. Dit gegeven dwingt tot een ernstige bezinning op de taak van de revalidatie-centra met betrekking tot geamputeerden. In dit verband is de kostenstijging van de Nederlandse Gezondheidszorg een reden te meer tot beraad over een zo efficiënt mogelijk gebruik van de middelen, die in thet kader van de Nederlandse Gezondheidszorg ten dienste staan.

Bij de zorg voor gehandicapten in onze samenleving en dus ook bij de zorg voor geamputeerden kan daaraan niet voorbij gegaan worden. 


\section{Lucasstichting voor Revalidatie.}

Hoensbroek heeft een grote rol gespeeld in de historie van Limburg. Rond het midden der $14 \mathrm{de}$ eeuw werd een begin gemaakt met de bouw van een ",sterke huisinghe". Hieruit ontstond het kasteel van Hoensbroek, wel eens het grootste slot tussen Maas en Rijn genoemd. Vanuit deze vesting werd eeuwenlang door de graven van Hoensbroek een onmiskenbare inwloed uitgeoefend op het wel en wee van deze provincie.

Vergeleken hiermee is de rol die Hoensbroek speelt in de gezondheidszorg van Limburg van zeer recente datum.

Op de Schurenberg, waar in 1885 de resten van een Romeinse villa werden blootgelegd, werd in augustus 1964 door de toenmalige "Stichting Lucasklinieken voor de Mijnstreek" begonnen met wat nu nog steeds een dynamisch werkend en groeiend complex is: ,De Lucasstichting voor Revalidatie".

De aanvankelijke doelstelling was voorbereiding, bouw en exploitatie van een combinatie van verpleegkliniek en revalidatiecentrum. De eerste verpleegpatiënt kon in juni 1967 worden opgenomen.

Intussen bleek dat in 1969 Limburg spoedig ruim zou zijn voorzien van verpleegbedden door de bouw van verpleeghuizen. De behoefte aan revalidatiebedden in Limburg werd daarentegen steeds groter. Bovendien groeide de visie dat het geheel eigen karakter van de revalidatie moeilijk met dat van de verpleegkliniek te combineren is. Op grond hiervan was het bestuur van mening dat de oorspronkelijke doelstelling herzien diende te worden. Het verzoek, in 197 I gericht aan de minister van Sociale Zaken en Volksgezondheid om de Lucaskliniek in haar geheel te bestemmen voor revalidatie, resulteerde in hetzelfde jaar in de erkenning watardoor het Revalidatie Centrum „Hoensbroeck" een feit werd. Enerzijds wil „Hoensbroeck" een regionaal centrum zijn, waarin alle voor revalidatie noodzakelijke aktivitei- 
ten zijn ondergebracht. Revalidatie van patiënten waarbij ernstige tijdelijke of blijvende lichamelijke functiestoornissen invoeging in het normalle milieu bedreigen. Voor het opstellen en verwezenlijken van een revalidatieprogram om deze functiestoornissen te verminderen, op te heffen of te compenseren, is een team van deskundigen en voorzieningen op velerlei gebied noodzakelijk: medisch, psychologisch, verpleegkundig, paramedisch, maatschappelijk, sociaal-cultureel, technisch, onderwijskundig en arbeidskundig.

Voorwaarde woor het welslagen van het revalidatieprogram is echter niet alleen de deskundigheid van de begeleiders of de outillage van het centrum. maar op de eerste plaats de wil van de patiënt om het maximaal haalbare te bereiken. Alleen voor de gehandicapte mens, die in staat is aan zijn revalidatie mee te werken is , Hoensbroeck" de juiste plaats.

Anderzijds wil "Hoensbroeck" een instituut zijn dat de revalidatie in de regio bevordert. Het kan dit doen door de samengebundelde, veelzijdige deskundigheid en outillage ter beschikking te stellen aan personen en instellingen, werkzaam op het gebied van de revalidatie.

Bovendien kan ..Hoensbroeck" mede voorzien in de behoefte aan beroepskrachten door stimulering en, waar nodig, realisering van beroepsopleidingen in het kader van de revalidatie. Het benadrukken van het regionale karakter komt indirect ten goede aan de patiënt. Immers een regionaal centrum biedt mogelijkheden tot het scheppen van een nauwe band met eerst behandelende huisartsen, specialisten, ziekenhuizen en verpleeghuizen. Een wederzijdse bevruchting van eerste- en tweede-lijnsgezondheidszorg en revalidatiecentrum wordt erdoor bevorderd. Het voor de opgenomen patiënt zo belangrijke contact met zijn eigen milieu kan worden behouden. Zijn ongeving wordt meer betrokken bij het revalidatieproces. Bovendien kunnen de regionale instanties, die de sociale en maatschappelijke belangen van de patiënt behartigen, tijdig worden ingeschakeld in het revalidatieproces.

Het moge duidelijk zijn dat de ombuigingsoperatie van verpleegkliniek naar de voor Nederland unieke structuur van de Lucasstichting voor Revalidatie niet in 1970 als concept ter tafel lag. Stap voor stap kregen de bovenomschreven twee grondgedachten in de afgelopen jaren steeds meer concreet gestalte. Zo moest in 1972 enerzijds gestreefd worden naar een geleidelijke afbouw van het aantal verpleegpatiënten, waarbij de verzorging en behandeling van deze patiënten onverminderd moest voortduren. Anderzijds werd alle aandacht en energie opgeëist voor de bouw van een modern klinisch revalidatiecentrum. Het bestaandle gebouw was als verpleegkliniek opgezet. Dit betekende dat de behuizing voor de mobiele revalidatiepatiënten veelal te eng was. Een snelle verbouwing van de afdelingen was noodzakelijk. Eind 1973 waren enkele afdelingen aangepast aan de eisen waaraan een reval idatiecentrum moet voldoen.

In tegenstelling met, ,verpleegd worden " betekent, ,revalideren" het doormaken van een leerproces. De hoofdverpleegkundigen zelf moesten een . leerproces" doormaken en tevens de verpleegkundigen en verzorgenden 
wan een afdeling begeleiden bij het leren van technieken en verpleegkundige attitude in de revalidatie. Ten aanzien van de verpleging had en heeft de nieuwe patiënt - de revalidant - vaak een verwachtingspatroon, dat is ontstaan tijdens het verblijf in een algemeen ziekenhuis in de acute periode van zijn ziekte. Het vereist inzicht, wijsheid, geduld en vastberadenheid van de revalidatieverplegende om het andere leef-en werkpatroon in het revalidatiecentrum aan de patiënt - de revalidant - duidelijk te maken en het te doen accepteren.

In januari 1973 vertrokken de laatste patiënten die op verpleeghuisindicaties waren opgenomen. Voor de medische dienst betekende dit ondermeer dat de longarts, die nu geen klinische patiënten meer onder zijn directe hoede had, meer aandacht kon gaan besteden aan belastingsonderzoek bij revalidanten. Sinds 1973 is de longfunctie-afdeling in belangrijk grotere mate ingeschakeld bij onderzoeken ten behoeve van de G.M.D., G.A.K. en andere instanties.

Het ligt voor de hand dat, waar een revalidatieproces gericht is op het vergroten van de restcapaciteit, de aandacht uitgaat naar bepaalde voorzieningen in leef- en werkmilieu. In 1972 werden deze voorzieningen nog uitgevoerd door de dienst ergotherapie, een onderafdeling van het revalidatiecentrum. De samenstelling van deze dienst was in 1972 als volgt: de afdeling ergotherapie (training in zelfverzorging, huishoudelijk werk e.d.); de afdeling arbeidstherapie (arbeidsevaluatie en training); de afdeling bezigheidstherapie (voorbereiding zinvolle vrijetijdsbesteding) en de afdeling onderwijs (algemene vorming en opleiding).

De afdeling arbeidstherapie onderging in 1973 een aanzienlijke uitbreiding en verbetering. Hierbij werd rekening gehouden met een eerste aanzet tot een ",prevocational training". Op deze afdeling werd speciale aandacht geschonken aan aanpassingen met betrekking tot technische hulpmiddelen (o.a. vervoermiddelen), woningadviezen en (terug)plaatsing in het bedrijf. In verband hiermee werden contacten gelegd met verschillende gemeenten, G.M.D., G.A.K., districtsgezondheidsdiensten, Z.O.L.-bedrijven* en het bedrijfsleven. In 1974 zette deze tendens zich voort.

\section{* Z.O.L.: W.S.W. Werkplatsen Zuid-Oost Limburg.}

Zoals reeds boven vermeld was vanaf 1973 pas volledig sprake van een revalidatiecentrum. De dienst ergotherapie was op den duur niet meer in staat te voldoen aan de eisen welke ten aanzien van voorzieningen gesteld worden, bedoeld om de restcapaciteit te vergroten. In 1973 waren dan ook de adaptatiewerkplaats en de overige werkplaatsen naast de in 1971 reeds aanwezige orthopaedische werkplaats en orthopaedische schoenmakerij in voorbereiding. Hieruit resulteerde uiteindelijk het R.T.H. (Revalidatie Techniek Hoensbroeck), een centrum dat anders dan de dienst ergotherapie, niet meer ressorteert onder het R.C.H. (Revalidatie Centrum Hoensbroeck), met een eigen verantwoordelijkheid ten aanzien van bestuur en directie van de Lucasstichting voor Revalidatie. Ongeveer analoog aan deze ergotherapie - R.T.H. - -ontwikkeling is het ontstaan van de V.I.A. (Voorbereiding Inschakeling - Arbeidsproces). Waren aanvankelijk de taken betreffende 
(her)inschakeling in het arbeidsproces toebedeeld aan de dienst ergotherapie binnen het R.C.H. in september 1974 werd gestart met de bouw van de V.I.A. Hier zouden vooral mogelijkheden ontstaan voor evaluatie van beroepsmogelijkheden, arbeidstraining en onderwijs als voorbereiding op de eigenlijke beroepsopleiding. In de eerste helft van 1976 werd dit nieuwe instituut geopend, waardoor een deeltaak van de dienst ergotherapie volledig overgedragen kon worden. Het voorheen bij andere diensten ingedeelde personeel vormde, samen met de nieuw aangetrokken krachten, een aparte werkgroep met als taakopdracht: ontwikkeling van programma's voor arbeidsevaluatie, training, resp. retraining in het oude of verwante beroep. praktische en theoretische voorbereiding op beroepsonderwijs. Organisatorisch is de V.l.A. verantwoording verschuldigd aan het R.C.H.

Als een logisch vervolg op de V.I.A. werd gestreefd naar de oprichting van een nieuw centrum, waarin op gehandicapten afgestemde opleidingsmogelijkheden gerealiseerd zouden moeten worden voor toekomstgerichte beroepen op middelbaar niveau. Dit centrum, het C.B.H. (Centrum Beroepsopleiding Hoensbroeck) is in statu nascendi.

De wordingsgeschiedenis van de andere centra, samen met R.C.H., R.T.H. en C. B.H. binnen de Lucasstichting voor Revalidatie moge anders verlopen zijn, in wezen hebben zij vanuit overigens andere invalshoeken een op revalidatie gerichte taak. De naam .,Revalidatie Centrum Hoensbroeck“ werd in de afgelopen jaren dikwijls gebruikt als een verzamelnaam voor alle binnen de Stichting aanwezige centra. Met ingang van 1976 wordt voortaan onder , Revalidatie Centrum Hoensbroeck" (R.C.H.) verstaan het centrum, dat zich richt op de directe patiëntenzorg, in casu de revalidatiekliniek en -polikliniek met de daarvoor noodzakelijke diensten ter behandeling en begeleiding van de gehandicapte tijdens zijn revalidatieproces.

Met ingang van 1976 bestaat dan een nieuwe organisatiestructuur. De algemene doelstelling van de nu tot ,Lucasstichting voor Revalidatie" omgedoopte rechtspersoon blifft dezelfde, te weten: , De revalidatie van gehandicapten en de bevordering der revalidatie, alles in de ruimste zin van het woord."

Bij de officiele opening van het Revalidatie Centrum op 3 juni 197 t werd deze doelstelling nader omschreven en samengevat in 4 punten:

1. Onderzoek, behandeling, opleiding en begeleiding van gehandicapten.

2. Bevordering van de revalidatie.

3. Opleiding van beroepskrachten in de revalidatie.

4. Wetenschappelijk onderzoek op het terrein van de revalidatie.

De stichting tracht hatar doel te bereiken door het oprichten, in stand houden en beheren van een aantal centra, alsmede door het geven van voorlichting en het verrichten van onderzoek. De later, meer gedetailleerd te beschrijven indeling van het werk in deze centra, hangt samen met de toch wel duidelijke verscheidenheid in werkzaamheden, wijze van financiering, patiënten of leerlingenpopulatie, contacten naar buiten, relatie met overheden e.d. Gemeenschappelijk blijft de opdracht: hulp aan de gehandicapte 
bij diens revalidatie en bevorderen van de revalidatie in de regio. Separaat zal meer of minder uitwoerig worden ingegaan op elk centrum. Hierbij zal blijken dat elk centrum taken verricht of zal kumnen verrichten op meerdere van de bovengenoemde vier deelgebieden van de doelstellingen van de . Lucasstichting voor Revalidatie". (Fig. 1)

LUCAS-STICHTING VOOR REVALIDATIE

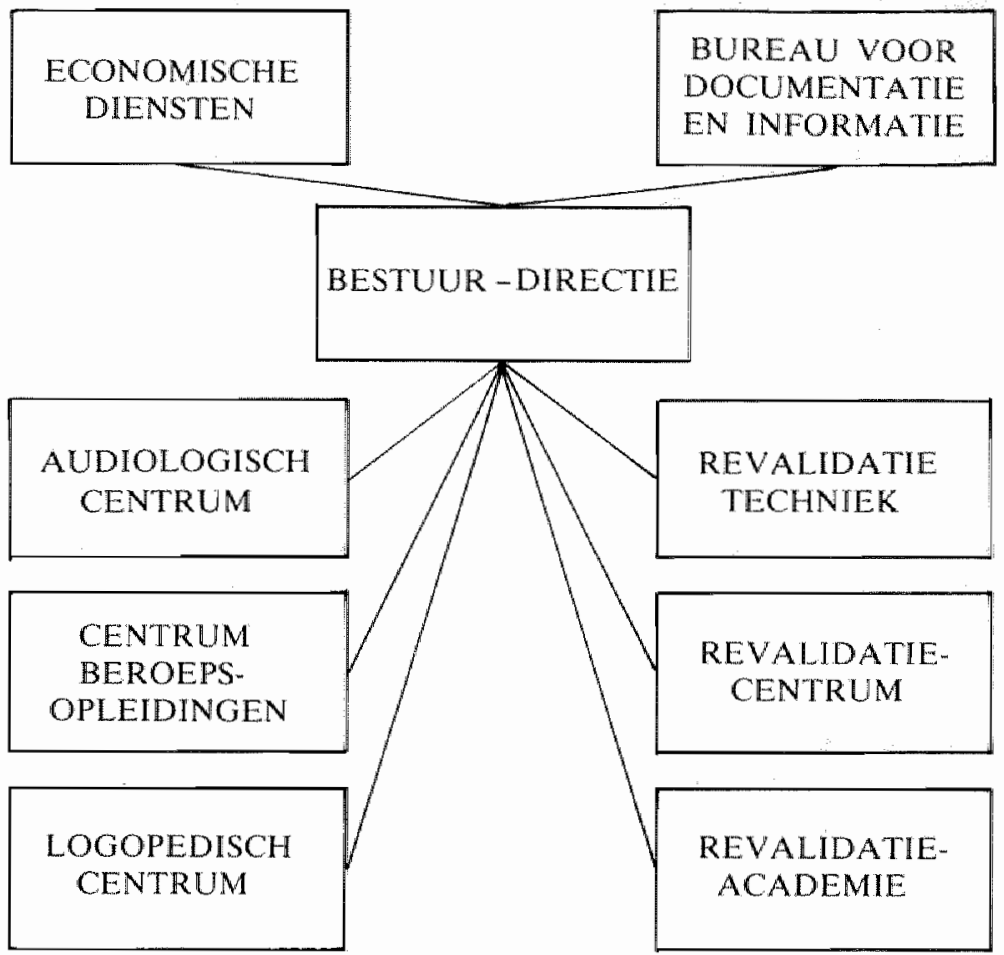

Fig. 1: Lucasstichting woor Revalidatie.

\section{1. Revalidatie Centrum Hoensbroeck (R.C.H.)}

De capaciteit van het Revalidatie Centrum Hoensbroeck bedraagt 160 bedden met daarnaast een beperkte mogelijkheid voor revalidatiedagbehandeling. Deze bedden worden verdeeld over 5 afdelingen, waar globaal de volgende categorieèn patiënten behandeld c.q. gerevalideerd worden.

I. Patiënten met letsels van ruggemerg en perifere zenuwstelsel (dwarslaesie-parese-paralyse).

II. Patiënten met amputaties van ledematen en patiënten met diverse orthopaedische afwijkingen.

III. Patiënten met rheumatische aandoeningen. 


\section{Patiënten met hersenbeschadigingen.}

V. Speciale afdeling voor gedragstherapeutische begeleiding van patënten met hersenbeschadigingen.

In het Revalidatie Centrum "Hoensbroeck" zijn een tiental artsen werkzaam bij de behandeling van de medische aspecten van een revalidant. Enerzijds specialisten van diverse pluimage, die ieder hun eigen deskundigheid inbrengen op een afdeling en daarnaast consulent kunnen zijn voor andere afdelingen. Consultatief optreden voor de omliggende algemene ziekenhuizen is mogelijk, echter dan wel op verzoek van de eventueel aldaar aanwezige revalidatie-arts. Anderzijds is het Revalidatie Centrum betrokken bij de opleiding van toekomstige revalidatie-artsen, die stage lopend door het gehele centrum, mede de medische aspecten van het revalidatieproces behartigen. Een aantal specialisten, werkzaam in de omliggende algemene ziekenhuizen, treedt op als consulent (neuroloog, neurochirurg, internist, orthopaedisch chirurg, plastisch chirurg, K.N.O.-arts en kinderarts).

De in het Revalidatie Centrum werkzame artsen zijn verantwoordelijk voor de diagnostiek en behandeling van de patiënt tijdens:
a. Het vooronderzoek.
b. Het revalidatieproces.
c. De eventuele poliklinische controle.

Indien noodzakelijk wordt tijdens het gehele revalidatieproces overleg gepleegd met verwijzende artsen en specialisten.

Naast deze specifiek medische taak is de arts coördinator en leider van het multidisciplinaire team dat de revalidant op elke afdeling begeleidt. Hierbij dient opgemerkt te worden dat de eigen beroepsverantwoordelijkheid van de onderscheidene teamleden door de teamleider, de arts, volledig erkend dient te worden. Coördinatie en leiding mag ook van hem verwacht worden wanneer het revalidatieteam contacten zoekt extramuraal, indien dit noodzakelijk blijkt tijdens het verloop van het revalidatieproces. Tenslotte is de arts nauw betrokken bij de medische registratie en archivering. Bijzonder belangrijk bij het bovengenoemde vooronderzoek en diagnostiek is de zogenaamde functie-afdeling met daarbij behorend de röntgenkamer en het laboratorium, welke onder leiding staan van een longarts. Deze functie-afdeling is voor het revalidatiecentrum zeer doelmatig gebleken. De functie-arts geeft zijn bevindingen door aan de afdelingsarts. Niet zelden worden bij deze beoordeling ook reeds cardiorespiratoir gerichte behandelingsadviezen en onderzoekmethoden aangegeven. De korte longfunctiescreening kan aanleiding zijn voor een nader longfunctie-onderzoek. (Dwarslaesie-patiënten, geamputeerden met silicose, Bechterew-patiënten.) Regelmatig herhalen van dit longfunctie-onderzoek kan voor diverse patiënten van belang zijn.

Elders zal nader ingegaan worden op het cardiotelemetrisch onderzoek en dan speciaal ten behoeve van geamputeerden. Hier wordt volstaan met te vermelden dat onder opklimmende belasting allerhande functies onder arbeidsomstandigheden getest kunnen worden met doorlopende E.C.G.- 
controle door midde】 van cardioscoop en cardiograaf.

Naast de afdelingsarts staat, nauw met hem samenwerkend, de verpleegkundige dienst. De verpleegkundigen en ziekenverzorgenden hebben niet primair een verzorgende, maar veeleer een stimulerende en aktiverende taak. Revalideren is immers opnieuw leren. Dit typisch eigen karakter wan het revalidatieproces komt tot uiting in de functie welke de verpleegkundige in het gehele revalidatieproces heeft. Naast deze begeleiding van de zelfwerkzaamheid van de revalidant, hetgeen weleens genoemd wordt ,verplegen met de handen op de rug", heeft de verpleegkundige tot taak het mede helpen oplossen van de mentale en emotionele problemen van de revalidant, die mede ontstaan door de vaak lange duur van het revalidatieproces. Tenslotte en zeker niet op de latste plaats moet de verpleegkundige mede bouwen aanen het in stand houden van een goed leefklimaat. Een leefklimaat dat een evenwichtige synthese dient te zijn tussen enerzijds de behoefte aan privacy en individualiteit en anderzijds het verlangen naar een vertrouwde leefgemeenschap. Dat het zuivere verpleegtechnische deel van de verpleegkundige dienst een conditio sine qua non is, hoeft hier niet benadrukt te worden. De opname van een soms zeer gehandicapte mens noodzaakt tot een strenge selectie van hen die deel uitmaken van de verpleegkundige dienst. Gevolg hiervan is dat aan opleiding en nascholing van de revalidatieverpleegkundigen in ons centrum veel aandacht wordt besteed.

Waar deze studie verantwoording poogt af te leggen met betrekking tot de revalidatie van in het Revalidatie Centrum opgenomen geamputeerden, voor zover elders nog geen prothesevoorziening had plaatsgevonden, rijzen 2 vragen:

a. Waarom werd destijds door bestuur en directie een afdeling aangewezen voor revalidatie van geamputeerden?

b. Waarom werd de leiding van deze afdeling opgedragen aan iemand die geen revalidatie-arts was van professie?

De beantwoording van deze vragen kan men terugvinden in , The future of the Artificial Limb Service in Scotland " (Scottish Home and Health Department, 1970). Hierin wordt gesteld: , the effect on the limb service in Scotland of the closer integration with other hospital services, particularly the orthopaedic service, has been widely recognised as beneficial. The problems associated with fitting artificial limbs and rehabilitating patients are cllosely akin to the hospital service, and a closer link with these departments has brought a broadening of vision to the artificial limb service and an impetus to the developments and improvements in it."

,,Most amputations are carried out in general hospitals and it is often not until some time after the operation when the stump has healed that full consideration is given to fitting an artificial limb. Unless other complications supervene the patient is then referred to the limb-fitting centre for assessment for the fitting of an artificial limb. In only a few cases does it not prove possible to fit a limb; but, although the situation has improved in recent years, 
there are still a number of patients who could probably have been better fitted if the surgeon performing the amputation had consulted before the operation with the prosthetic surgeon on sites and techniques."

.Where amputation is not carried out by the prosthetic surgeon it is of the utmost importance that there should be the closest liaison between the surgeon performing the amputation and the prosthetic surgeon. Though liaison exists in some areas, in general, closer co-operation would be of advantage. Because of the high proportion of amputations resulting from peripheral vascular disease, the need for liaison between surgeons treating such cases and prosthetic surgeons is particularly evident. Peripheral vascular surgery will obviate the need for amputation in proportion of patients, and permit of amputation at a lower level in others; for the future, however, the reduction in the number of amputations because of improved vascular techniques is unlikely to do more than balance the increase in numbers which may be expected from an ageing population. Though the amputation may prove inevitable when medical treatment or restorative surgery has no more to offer, this need not signify that the patient can not pursue an active role within his community. Amputation can and should be regarded as part of a rehabilitation process, the removal of a diseased or damaged member to be followed by its replacement by a device, which, although never as good as a sound natural limb, at least gives reasonable pain-free function. The patient should be encouraged to look upon his situation in this way and where possible, his education should start before operation so that his fears are allayed and he can look to the future with confidence and assurance."

Uitgaande van bovengenoemd rapport uit Schotland werd gesteld dat, althans voor de provincie Limburg, behoefte was aan een aantal revalidatiebedden voor geamputeerden. De afgelopen jaren hebben aangetoond dat deze berekening, geëxtrapoleerd uit bovengenoemd rapport, geen misrekening is geweest. De verantwoording hieromtrent in andere hoofdstukken moge dit nogmaals onderstrepen.

In het rapport uit Schotland is steeds sprake van een ..Prosthetic Surgeon". Een Prosthetic Surgeon, die samen met de chirurgen in omliggende algemene ziekenhuizen een organisatie moet opbouwen ten behoeve van een betere verzorging en revalidatie van geamputeerden. Deze Schotse opvatting is niet nieuw. In landen, bijw. West-Duitsland, waar het specialisme revalidatie (nog) niet bestaat, is de revalidatie van gehandicapten toevertrouwd aan orgaanspecialisten, die grotendeels afscheid genomen hebben van hun vakgebied om zich alleen te kunnen wijden aan en in te zetten voor de revalidatie van patiënten, voortkomend uit hun vroegere professie.

Op grond van de elders behaalde resultaten werd door bestuur en directie van het Revalidatie Centrum deze opvatting niet meteen terzijde gelegd maar in overweging genomen. Het gevolg hiervan is geweest dat in 1972 de leiding van de afdeling, waar geamputeerden gerevalideerd worden, toevertrouwd werd aan een chirurg, die zich zeker nog geen Prosthetic Surgeon kon of wilde 
noemen. Of ook dit bestuit een juiste decisie was, is een van de redenen geweest voor deze studie: het alleggen van verantwoording omtrent een andere behandeling van geamputeerden in de regio.

De nu volgende beschrijving van de andere centra brengt ook die instituten voor het voetlicht. welke in eerste instantie weinig te maken lijken te hebben met de revalidatie van beengeamputeerden. Bij nadere beschouwing blijk echter dat de Lucasstichting streeft natar een coöndinatie en concentratie van deskundigheid en voorzieningen, warop regelmatig een beroep kan worden gedaan. indien de noodzaak hiertoe zich woordoet tijdens het revalidatieproces.

\section{I.2. Het Audiologisch Centrum (A.C.H.)}

Het audiologisch centrum beoogt het onderzoek en de revalidatie van de gehoorgestoorde mens door een team van deskundigen. Dit team bestaat uit een fysicus-audioloog, een K.N.O.-arts, een psycholoog, een maatschappelijk werkende, een logo-acopedist en een electronicus.

De taak van het audiologisch centrum is tweeledig. Op de eerste plats heeft het audiologisch centrum een regionale taak. De opsporing van een slechthorend kind vindt momenteel op steeds jongere leeftijd plaats. Om het gehoorverlies zo nauwkeurig mogelijk vast te stellen is zeer uitgebreide apparatuur noodzakelijk. Is het gehoorverlies voldoende nauwkeurig vastgelegd, dan kan begonnen worden met de aanpassing van een hoortoestel. Dit kan reeds plaatsvinden vanaf de leeftijd van ca. I jaar. Om het kind optimale ontwikkelingskansen te bieden is het noodzakelijk dat vanuit het centrum de ouders en het kind zeer intensief worden begeleid. Bij schoolgaande kinderen zal, naast de begeleiding van de ouders en het kind, ook de school hierin moeten worden betrokken. Het streven is dan ook om slechthorende kinderen zoveel mogelijk het gewoon lager onderwijs te laten volgen. Is het gehoorverlies zodanig dat plaatsing opeen school voor slechthorenden noodzakelijk is, dan beperkt de zorg van het audiologisch centrum zich tot het audiologisch gedeelte.

Op de tweede plats heeft het audiologisch centrum een taak voor het R.C.H. Regelmatig wordt vanuit het R.C.H. het audiologisch centrum te hulp geroepen. wanneer naast de handicap waarvoor de patiënt opgenomen is "een gehoorstoornis bestaat. Immers een revalidant "bijvoorbeeld met een beenamputatie, te instrueren hoe hij zich een nieuwe looptechniek eigen kan maken vooronderstelt verbale communicatte. Het aanpassen van een hoortoestel is niet altijd voldoende. De gehoorgestoorde mens is vaak in een isolement geraakt. Dan is belangrijk dat naast de aandacht voor de gehoorgestoorde mens de omgeving betrokken wordt bij de revalidatie. Het zou voor iedereen duidelijk moeten zijn wat men van de gehoorgestoorde kan en mag verwachten. Het audiologisch centrum kan in deze waardevolle adviezen geven. Tenslotte wordt steeds vaker een beroep op het audiologisch 
centrum gedaan om mee te werken aan een stuk medische diagnostiek. Hierdoor kan de aard en de graad van de laesie nauwkeuriger vastgesteld worden, zodat een eventueel gericht advies voor een the rapie of operatie mogelijk wordt.

\subsection{Het Logopaedisch Centrum Hoensbroeck (L.C.H.)}

Dit onderdeel van de Lucasstichting voor Revalidatie heeft als doelstellingen:

I. Diagnostiek. Onderzoek van patiënten met spreekstoornissen en advies aan verwijzers.

II. Bevordering van de revalidatiemogelijkheden door therapie of behandeling en begeleiding van patiënten met spreekstoornissen.

III. Preventieve activiteiten.

IV. Didactisch-informatieve aspecten.

V. Wetenschappelijk onderzoek.

Dit centrum beschikt over 7 logopaedisten, met daarnaast part-time een K.N.O.-arts, een maatschappelijk werkende en een psycholoog.

De taak van de logopaedisten omvat:

- Onderzoek en behandeling van patiënten van het R.C.H.

- Onderzoek en behandeling van poliklinische patiënten.

- Schoollogopaedisch onderzoek en behandeling t.b.v. een beperkt aantal scholen, zowel op L.O.- als op B.L.O.-niveau. Het betreft hier een beperkt aantal scholen (in totaal 8), omdat gestreefd wordt naar een geïntegreerde schoollogopaedie.

De K.N.O.-arts heeft tot taak stemonderzoek en onderzoek van organische spraakstoornissen, voor zover dit nog niet gedaan werd of voor zover de patiënt nog niet bekend was bij een extramurale K. N.O.-arts. De K.N.O.arts adviseert bij stem- en spraakbehandelingen.

De maatschappelijk werkende onderzoekt de sociale aspecten bij stotteraars, stem- en lipleespatiënten (gezin. werkkring, vereniging) en geeft adviezen bij spreekstoornissen, waar het milieu een voorname rol speelt. Tenslotte heeft hij een inbreng bij doorverwijzing van patiënten naar andere hulpverlenende diensten.

De psycholoog onderzoekt en adviseert t.a.v. psychisch afwijkend gedrag, ontstaan door de stem-, spraak- of taalstoornissen. 
Diagnostiek wordt verricht met betrekking tot de aard en de oorsprong van de spreekstoornissen. Hieruit kan volgen een advies aan verwijzer, aan de behandelend logopaedist, aan de ouders of aan de leerkracht.

De regio welke van deze diagnostische diensten gebruik maakt omvat Kerkrade, Brunssum, Maastricht, Heerlen, Sittard, Roermond en Geleen, alsmede de gemeenten gesitueerd rond deze kernen. De eventuele logopaedische behandeling voortvloeiend uit de diagnostiek, beperkt zich echter tot:

- Hoensbroek en directe ongeving.

- Patiënten, die onmiddellijke en intensieve behandeling behoeven.

- Patiënten, waarbij groeps- en/of teambehandeling nodig is.

\section{Ad III. en IV. Preventieve activiteiten en Didactisch-informatieve aspecten}

Deze aspecten van het L.C.H. omvatten ondermeer: een cursus logopaedie voor onderwijzers en leerkrachten van het basisonderwijs. Doel hiervan is:

- Beter inzicht te geven in de spreekstoornissen, voorkomend in het kleuteren basisonderwijs.

- Het alerter maken van de leerkrachten voor deze problematiek.

- Inzicht geven in de opbouw van een logopaedische behandeling.

- Hel geven van adviezen ten aanzien van voortzetting en ondersteuning van de logopaeden in de klassituatie.

\section{Ad. V. Wetenschappelijk onderzoek}

Het L.C.H. werkt ondermeer samen met de Katholieke Universiteit te Leuven en het Academisch Ziekenhuis te Utrecht.

\section{I.4. Centrum voor Revalidatie-Techniek Hoensbroeck (R.T.H.)}

Hulmiddelen en technische voorzieningen kunnen voor gehandicapten van groot belang zijn om een maximum aan haalbare zelfstandigheid te bereiken. Die hulpmiddelen verrichten dan functies die de gehandicapte niet meer kan uitvoeren.

Men kan stellen, dat in vele gevallen technische voorzieningen een revalidatieproces moeten ondersteunen en dan een voorwaarde zijn voor het slagen c.q. afronden van dit proces. Doorgaans zullen dan ook de technische voorzieningen vanuit het behandelteam ter sprake komen in dat stadium van het revalidatieproces, waarin de restfuncties van de gehandicapte in belangrijke mate gestabiliseerd zijn of redelijk voorspelbaar zijn. Voor de realisering van de vereiste technische voorzieningen zal er een nauwe samenwerking dienen 
te bestaan tussen de medische en paramedische disciplines en diegenen die de hulpmiddelen ontwerpen en vervaardigen. Een teamsgewijze benadering vark deze problematiek is dan ook dikwijls geboden, zeker wanneer het gaat om voorzieningen waarbij oefening en training een rol spelen.

Binnen de Lucasstichting voor Revalidatie zijn een aantal technische disciplines en diensten aanwezig in de vorm van een Centrum voor RevalidatieTechniek Hoensbroeck, die gezamenlijk ower alle technieken, know-how en materialen beschikken omtrent technische voorzieningen. Om deze mogelijkheden, die ten behoeve van het Revalidatie Centrum Hoensbroeck noodzakelijk aanwezig zijn, mede ter beschikking te stellen aan de regionale behandelaars en verstrekkers, is het Centrum voor Revalidatie-Techniek een instituut dat ook in directe relatie staat tot de perifere behandelaars en verstrekkers.

Doordat het R.T.H. geografisch en organisatorisch dicht bij het behandelcentrum R.C.H. ligt, kan daarmee een optimale samenwerking ontstaan voor de R.C.H.-patiënten en anderzijds kan de externe opdrachtgever een beroep doen op de technische mogelijkheden en know-how die normaliter alleen bij een revalidatiecentrum aanwezig zijn.

Door schaalvergroting en een veelvoud van contacten kan een grotere plaats gereserveerd worden voor onderzoek en ontwikkeling t.b.v universele hulpmiddelen.

De werkzaamheden van het R.T.H. zijn te onderscheiden in:

- Het geven van adviezen en voorlichting aan behandelaars, verstrekkers en gehandicapten.

- Het maken en leveren van hulpmiddelen in opdracht van behandelaars en verstrekkers (G.M.D. en ziekenfondsen), inclusief de ontwikkeling van deze individuele hulpmiddelen.

- Het onderzoek en ontwikkelen van nieuwe hulpmiddelen voor universele problemen.

In het nog relatief jonge bestaan van het R.T.H. neemt de tweede groep werkzaamheden, namelijk de produktie van individuele hulpmiddelen, de grootste plaats in. Uiteindelijk zal dit individu-gerichte werk, implicerende produktieve en commercieel gerichte activiteiten, ook de basis moeten zijn voor onderzoek en ontwikkeling.

Voor het uitbrengen van adviezen en algemene voorlichting is een produktdocumentatie alsmede expositie aanwezig. Indien enigszins mogelijk worden individuele adviezen bekrachtigd met een experimentele toetsing. De hiervoor noodzakelijke materialen zijn aanwezig in het hulpmiddelendepôt. De dienst Verstrekkingen begeleidt deze activiteiten, evenals de coördinatie tussen de verstrekker, leveranciers, gebruiker en aanvrager. Ondanks de grote hoeveelheid handelsartikelen blijft het nodig om legio hulpmiddelen door de sterk individu-gebonden uitvoering op maat te maken of te veranderen. Voor deze activiteiten zijn een drietal werkplaatsen aanwezig: 
- De orthopaedische-instrumentmakerij: prothesen, orthesen, spaken, beugels en corsetten. De opleiding van orthopaedisch-instrumentmaker geschiedt in samenwerking met Bemetel (De stichting .,Bedrijfsopleiding in de Metaal-en Electronische Industrie).

- De orthopaedische schoenmakerij: schoenen, voetprothesen en verandering van confectieschoenen. De werkwijze is sterk congruent met die van de orthopaedische instrumentmaker.

- De adaptatie-werkplaats met het hulpmiddelendepôt: vervoer, A,D,L. (Activiteiten van het Dagelijks Leven), woningen, enz.

De derde activiteit, namelijk onderzoek en ontwikkeling van hulpmiddelen is te onderscheiden in toegepast en fundamenteel onderzoek. In zoverre als het produkt-ontwikkeling (bekende materialen en technieken toepassen voor ander doel, construeren en ontwerpen) en toegepast onderzoek betreft, kan dit zelfstandig uitgevoerd worden. Het fundamenteel onderzoek geschiedt in samenwerking met de daartoe aanwezige instituten zoals Universiteiten, Technische Hogescholen en T.N.O.

\section{I.5. B.I.O.S. Centrum Hoensbroeck. (Bevordering Integratie Ontspanning Sport.)}

Het B.I.O.S. Centrum vindt zijn taak op het terrein van de sociale revalidatie. De doelstellingen van dit Centrum zijn de volgende:

- bevorderen van de integratie van gehandicapten in de maatschappij:

- verbetering van de fysieke conditie door recreatieve- en wedstrijdsport;

- prettige en zinvolle besteding van vrije tijd door het bieden van alternatieven voor beroepsarbeid, door deel hebben aan cultuur, door bieden van mogelijkheden tot recreatie;

- het voor de gehandicapte mogelijk maken eigen potentie en eigen beperkingen in de praktijk te beoordelen.

Dit project bestaat uit:

1. Een ontmoetingscentrum.

2. Terreinen voor sport en recreatie in de open lucht.

3. Overdekte sportaccomodatie.

Ad. 1.

Het ontmoetingscentrum omvat:

- gezelschapsruimten met bar en spelmogelijkheden;

- ruimten voor binnensport als tafeltennis, biljart, enz.;

- 2 zalen voor muziekclubs, gespreksgroepen en hobbyclubs.

Ad. 2.

Het sport-en recreatieterrein omvat:

- een verhard sportveld; 
- onverharde terreinen voor sportbeoefening;

- tuin en dierenpark;

- een springbak, een zandbak voor kinderen, e.d.

\section{Ad. 3.}

De overdekte sportaccomodatie bestaat uit:

- een $z$ wembad voor $z$ wemonderwijs, recreatief zwemmen en wedstrijdzwemmen;

- een sportzaal voor diverse sporten;

- een overdekte boogschietbaan;

- bijbehorende ruimten voor sportbeoefenaars en toeschouwers.

Het Centrum is bestemd voor:

- Patiënten van het klinisch revalidatiecentrum, poliklinische revalidatiepatiënten.

- Revalidanten van instituten voor arbeidstraining en beroepsopleiding.

- Leerlingen van scholen voor gespecialiseerd onderwijs, b.v. de School voor Slechthorenden en Spraakgebrekkigen.

- Gehandicapten uit de omgeving, waarbij vooral gedacht wordt aan ernstig gehandicapten voor wie speciale voorzieningen en/of gespecialiseerd personeel nodig zijn.

- Degenen die nog geen gebruik kunnen maken van sportcentra in eigen woonplats en eerst een leerperiode moeten doormaken.

- Voor hen die sport in groepsverband willen beoefenen, doch die in eigen omgeving onvoldoende partners met vergelijkbare mogelijkheden aantreffen.

- Sportmanifestaties (regionaal, nationaal, internationaal).

\section{I.6. De Revalidatie Academie, ,Hoensbroeck". (R.A.H.)}

Sinds het begin van de zeventiger jaren is aan de Lucasstichting voor Revalidatie een opleiding verbonden die momenteel de naam draagt: Academie voor Revalidatie. Deze omvat de opleidingen Logopaedie en Ergotherapie. Primair stelt de Revalidatie Academie zich tot doel het oprichten en in stand houden van Hogere Beroepsopleidingen op het gebied van de revalidatie. Tevens ziet zij als haar taak het initiatief nemen tot of medewerking verlenen aan:

- Studie van beroep in het werkveld van de revalidatie en van de eisen die daaruit voortvloeien voor de opleiding.

- Bevorderen van het tot stand komen van nieuwe opleidingen, indien dit voor een optimale revalidatie gewenst is.

- Bevorderen van de samenwerking met andere Hogere Beroepsopleidingen.

- Het scheppen van bijscholingsmogelijkheden en

- de oprichting van voortgezette opleidingen op universitair niveau. 
Zoals gezegd zijn thans in de Revalidatie Academie Hoensbroeck ondergebracht een opleiding voor Logopaedist en Ergotherapeut.

\section{- Opleiding Logopaedie-Acoepedie.}

Deze hogere beroepsopleiding beoogt de studenten toe te rusten met de kennis, de vaardigheden en de beroepshouding die hen in staat stellen het beroep Logopaedist uit te oefenen. Daarbij gaat het om vorming tot een beroepsbeoefenaar, die in staat is spraak-, taal-, stem- en gehoorstoornissen bij de mens te onderkennen en deze in een therapeutische relatie te behandelen in samenwerking met andere specialisten.

\section{- Opleiding Ergotherapie.}

Het beroep Ergotherapeut richt zich op het revalideren van mensen die geestelijk en/of lichamelijk ziek zijn, tijdelijk dan wel blijvend gehandicapt zijn. De gediplomeerde Ergotherapeut betrekt de patiënt bij arbeidsactiviteiten, die methodisch worden opgebouwd en doelgericht worden gebruikt in specifiek gekozen situaties, opdat de patiënt kan gaan deelnemen aan het leven in al zijn facetten, zowel met betrekking tot de eisen die de patiënt aan zichzelf stelt als aan de eisen die zijn woon-, leef-en werkmilieu aan hem stellen. Deze hogere beroepsopleiding is gericht op het doen verkrijgen van kennis, inzicht en vaardigheid en het vormen tot een voor het beroep Ergotherapeut vereiste grondhouding.

\section{I.7. V.I.A. (Voorbereiding Inschakeling Arbeidsproces).}

Op het gebied van de beroepsmogelijkheden voor gehandicapten ontbreekt nog veel. Vele gehandicapten willen en kunnen normaal werken als hen tijdig de juiste opleidingsfaciliteiten worden geboden. Mikkend op een (over)compensatie van de handicap werd zorgvuldig onderzoek verricht naar beroepsmogelijkheden, gerichte arbeidstraining in nauwe samenwerking met de gebruikelijke therapiën en een scholing in toekomstgerichte beroepen met behulp van moderne onderwijsmethoden. Dit is de enige manier om de gehandicapte in staat te stellen zijn aanwezig werkpotentieel te ontwikkelen en te benutten. De medewerking van de gehandicapte mag worden verwacht als door een dergelijke inspanning een betere toekomst voor hem in het verschiet ligt.

Bij de gedachtenvorming en de plannen hebben de ervaringen met de beperkte mogelijkheden voor de gehandicapten t.a.v. toetsing van studie- en arbeidsvermogens, arbeidstraining en scholing een grote rol gespeeld. Deze zaken waren naar de mening van de directie in Nederland nog te weinig van de grond gekomen, ondanks de meerdere initiatieven van overheid en particu- 
liere organisaties. Het buitenland bood diverse voorbeelden: Industrial Rehabilitation Units in Engeland, het Tower-System in Amerika (Testing. Orientation and Work Evaluation in Rehabilitation) en de Berufstherapie die we in Duitsland aantreffen. Deze invloeden hebben ertoe geleid dat een aparte revalidatiedienst werd gerealiseerd: de V.I.A. (Voorbereiding Inschakeling Arbeidsproces). Deze V.I.A. beoogt al in een vroeg stadium van het revalidatieproces een gerichte inbreng te leveren door:

- Toetsing van studievermogens.

- Toetsing van arbeidsvermogens.

- A.V.O (Algemeen Vormend Onderwijs) en onderwijs als vooropleiding, gericht op een latere beroepsopleiding.

- Arbeidstraining, resp. re-training in het oude beroep of in een verwant beroep.

- Oriëntatie na mogelijkheden voor arbeidsvervangende bezigheden.

Men kan zich afvragen: Is arbeid nog belangrijk in onze tijd; Is arbeid nog belangrijk voor een gehandicapte? Arbeid wordt gedefinieerd als: , moeite, inspanning van geestelijke en/of lichamelijke aard on iets tot stand te brengen". (Koenen-Endepols). Ook een gehandicapte wil iets tot stand brengen, wil niet uitgerangeerd zijn. Ook al vervallen waarden als status of de noodzaak te voorzien in bepaalde financiële behoeften, dan nog blijven andere punten van grote waarde yoor het zelfrespect. En deze factoren spelen ook een rol in het leven van de gehandicapte. Niet zozeer als middel tot het verkrijgen van status of geld, maar werk als middel tot:

- Zelfverwerkelijking: de behoefte om iets tot stand te (kunnen) brengen.

- Gevoel van eigenwaarde tegenover het gezin.

- Gezonde wedijver met de medemens.

- Sociaal contact.

- Richting geven aan prestatiedrift.

- Inhoud geven aan levenspatroon en levensritme.

- Beleven van verantwoordelijkheidsbesef.

- Stimuleren van zelfvertrouwen.

\section{I.8. Centrum yoor Beroepsopleidingen Hoensbroeck (C.B.H.).}

Uit een onderzoek van het wetenschappelijk instituut van de G.M.D. is gebleken dat een groot percentage W.A.O.-gerechtigden de wens te kennen gaf deel te mogen nemen aan het arbeidsproces (J. M. de Klerk 1976). Deelname eventueel na een opleiding of omscholing, noodzakelijk gezien het bestaan van een handicap. Mede door het initiatief van de Lucasstichting zijn de laatste jaren activiteiten op gang gekomen, die als resultaat zeer duidelijk de wens naar een eigen opleidingsinstituut voor volwassen gehandicapten in Nederland tot uitdrukking hebben gebracht.

Men kan zich afvragen of een dergelijk instituut als het C. B. H. wel zinvol is in een tijd warin we met grote werkloosheid kampen. Achter deze vraag staat vooral de vrees, dat alle moeite gedurende de opleiding gedaan, vergeefs is. Immers, waar zijn de arbeidsplaatsen voor de gehandicapten? Dit aspect 
van het probleem kan niet zonder meer terzijde worden gelegd. Het is een reëel aspect, omdat het uitgaat van de realiteit.

Uitgaande van de positie van de gehandicapte, - en daarvan moet in eerste instantie worden uitgegaan -, zou het niet realiseren van een opleidingsinstituut de gehandicapte dubbel benadelen. Bovendien blokkeert deze manier van denken teveel een verdere ontwikkeling in het revalidatiegebeuren, omdat bestaande problemen rond de economische crisis dan te sterk de nadruk krijgen. Het is well absoluut noodzakelijk om de te verwachten problemen te signaleren teneinde daarvoor tijdig naar oplossingen te zoeken. Het is onze plicht de mogelijkheden, die naar een zinvol arbeidsleven voor de gehandicapte leiden, optimaal te ontwikkelen, waarbij men beslist van mening kan verschillen over de verschillende wegen om dit te realiseren.

Het C.B.H. is in de eerste plaats een opleidingsinstituut voor volwassen gehandicapten. Dit betekent niet dat het C.B.H. slechts als een steriel opleidingsinstituut kan worden beschouwd. Ook het C.B.H. is een revalidatiecentrum, waarbij het accent van de activiteiten op de beroepsopleiding ligt.

Het begrip revalidatiecentrum is nog te vaak en te veel synoniem met activiteiten, die medisch en paramedisch georiënteerd zijn. Een revalidatieproces houdt echter meer in dan medische en paramedische behandeling. De aspecten van het arbeidsleven spelen voor de uiteindelijke reïntegratie een zeer belangrijke rol. Zo gezien is het C.B.H. voor een aantal gehandicapten het laatste deel van het revalidatieproces, waarin dan de opleiding centraal staat en een goede begeleiding op medisch en psychosociaal gebied het deelnemen aan de opleiding mogelijk maakt. Afgesloten wordt deze fase door de plaatsing in het vrije bedrijfsleven, bij de overheid ofwel semi-overheid. Dat met name dit laatste punt bijzondere inspanning vereist werd reeds gesignaleerd.

Het C.B.H. is een instituut voor volwassen gehandicapten, van wie de handicap zodanig is, dat ze hierdoor niet of nauwelijks aan reeds bestaande opleidingen kunnen deelnemen. Wel horen de intellectuele capaciteiten op een zodanig niveau te liggen, dat de beroepsopleiding op kwalitatief behoorlijk peil kan worden afgesloten. De opleiding is zodanig gestructureerd dat deze in vergelijking met bestaande opleidingen tenminste gelijkwaardig en zo mogelijk zelfs meer inhoudt.

In beginsel zullen geen gehandicapten worden opgenomen, die hun handicap vanaf de geboorte hebben, omdat voor deze categorie vaak andere instellingen bestaan. Meestal zullen het mensen zijn, die hun handicap op latere leeftijd kregen door ongeval of ziekte met als gevolg dat ze hun beroep moesten opgeven.

Het C.B.H. wil meehelpen deze mensen weer in het maatschappelijk leven te integreren door middel van een gekwalificeerde beroepsopleiding. De opleidingsrichtingen zijn voorlopig: electronica, fijnmechanica, administratieve sector en technisch tekenen. De duur van de opleiding is ingebouwd in een periode van 2 jaar, waarin gestreefd wordt naar een niveau dat ligt tussen lager en middelbaar beroepsonderwijs en veelal het laatste niveau het meest nabij komt. Differentiatie binnen een bepaalde beroepsgroep is mogelijk of wordt in ieder geval nagestreefd. Het C.B.H. werkt in groepswerband en heeft een capaciteit van 150 opleidingsplaatsen. Een bijzonderheid van het 
C. B.H. is de interne opleiding, als eerste instituut in Nederland op het gebied van beroepsopleidingen voor gehandicapten. De 150 revalidanten, afkomstig dus uit het gehele land, worden gehuisvest in een woonftat binnen het complex van de Lucasstichting. Op grond van ervaringen in het buitenland zal onderwijs in traditioneel klassikaal verband binnen het C.B.H. niet meer prevaleren. Groepen van 15 revalidanten worden begeleid door docenten, die in eerste instantie als partner van de gehandicapte de richting bepalen en hem zover brengen dat hij zelfstandig verder kan. Nieuwe ontwikkelingen in het bedrijfsleven worden door deze kleine werkgroepen met o.a. mensen uit het bedrijfsleven gesignaleerd en moeten onmiddellijk hun weerslag vinden in de opleiding. Door deze vorm van onderwijs, waarbij de vooruitgang van de revalidanten ook regelmatig door confrontatie met de latere beroeps- en werksituatie wordt gemeten, meent de Lucasstichting meer te kunnen bijdragen aan de vereiste zelfstandigheid. Nauwe samenwerking met V.I.A., G.M.D. en G.A.B. is geboden voor het verkrijgen van de nodige gegevens voor de selectieprocedure. Binnen de Lucasstichting zullen de diverse centra met elkaar voeling moeten blijven houden na plaatsing van een revalidant in het C.B.H., wil het sluitstuk van de revalidatie een optimale kans krijgen.

De Lucasstichting beoogt als uiteindelijk doel het scheppen van optimale kansen voor gehandicapten. ,Optimale kansen" betekent dat aan de gehandicapte alle mogelijkheden moeten worden geboden om zich in de samenleving volledig als persoon te kunnen ontplooien. Alleen door integrale deelname aan de verschillende levensgebieden, zoals familie en gezin, arbeid en beroep of vrije tijd, algemene vorming en onderwijs, is een optimale zelfrealisatie mogelijk. Daarbij dient rekening te worden gehouden met het feit, dat vaak een volledig herstel van het defect niet mogelijk is. De restcapaciteit zal in dat geval zodanig ontwikkeld dienen te worden, dat het defect gecompenseerd of zelfs overgecompenseerd wordt. Blijkens de ervaring heeft de mens onvermoede mogelijkheden. De gehandicapte moet voorbereid worden op de terugkeer in een maatschappij, die ingesteld is op niet gehandicapten. Om dit te bereiken is een gecombineerd en op elkaar afgestemd geheel van maatregelen op medisch en niet-medisch terrein noodzakelijk. ,Als we, om dit alles vlot te laten verlopen, de maatregelen van velerlei instanties binnen en buiten de muren van het Centrum bijeen moeten garen, brengt dit niet alleen tijdverlies met zich mee, maar ook het risico dat een gecombineerd en op elkaar afgestemd gebruik van deze maatregelen ernstig gevaar loopt. Het effect van de revalidatie-inspanningen is groter naarmate het Centrum (lees: Lucasstichting voor Revalidatie) in zijn brugfunctie naar de samenleving zoveel mogelijk facetten van de totale revalidatie binnen zijn muren kan bieden". (te Riele 1974). De revalidatie van de individuele patiënt bestaat niet uit brokjes medische, paramedische, psychologische, sociale, onderwijskundige en arbeidskundige zorg, maar uit een volledig geïntegreerd program van hulpverlening vanuit genoemde sectoren. Coördinatie en concentratie van deskundigheid en voorzieningen is vereist. 


\section{Behandeling van geamputeerden, vroeger en nu.}

De geschiedenis van de mens laat voldoende voorbeelden zien van pogingen om een medemens, getroffen door het verlies van een lidmaat te helpen. Dat een optimale revalidatie vaak een wensdroom bleef in het verleden, daarvan zijn wij ons wel bewust nu wij zelf nog met zoveel problemen kampen.

In diverse musea en kerken, o.a. in de kathedraal van Lesçar in Frankrijk, worden fragmenten van vazen en urnen aangetroffen waarop afbeeldingen van geamputeerden en steltprothesen. (Fig. 2)

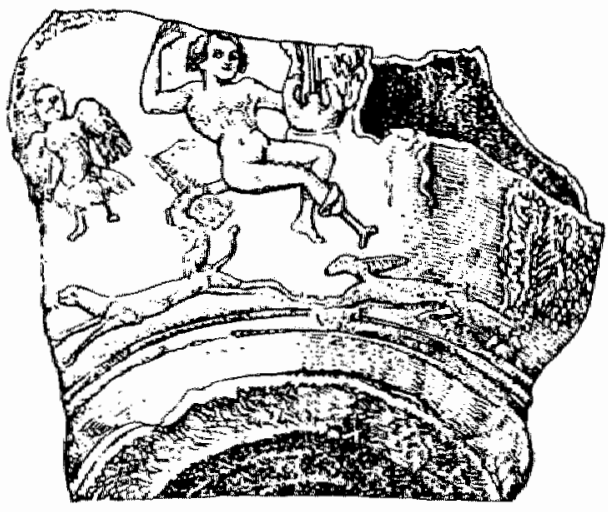

Fig. 2: Fragment van anticke was.

In de 5e eeuw voor Christus registreert Herodotus als eerste het verhaal van een amputatie en prothesevoorziening: Hegistratus, een ziener uit Elis, onttrok zich aan de Spartaanse gevangenschap door eigenhandig zijn in ketenen geklonken voet af te snijden. Voorzien van een houten prothesevoet zou hij zich weer in het krijgsgewoel gestort hebben. (Friedman $\$ 973$, Breslau 1956.) Plinius noteert dat de Romein Marcus Sergius in de tweede Punische oorlog (218 tot 201 voor Christus) zijn rechter hand verloor. Met een handpro- 
these van ijzer trad hij de vijand weer tegemoet. (Breslau 1956.) De Middeleeuwen waren een tijdvak waarin veel ledematen verloren gingen als gevolg van oorlogsverwondingen, lepra en het afhakken van extremiteiten als strafmaatregel. Huizinga (1957) schrijft in ,Herfsttij der Middeleeuwen" ", "Tegen rampen en gebrek was minder verzachting dan nu; zij kwamen geduchter en kwellender. Ziekte stak sterker af bij gezondheid; de barre koude en het bange duister van den winter waren een wezenlijker kwaad. Eer en rijkdom

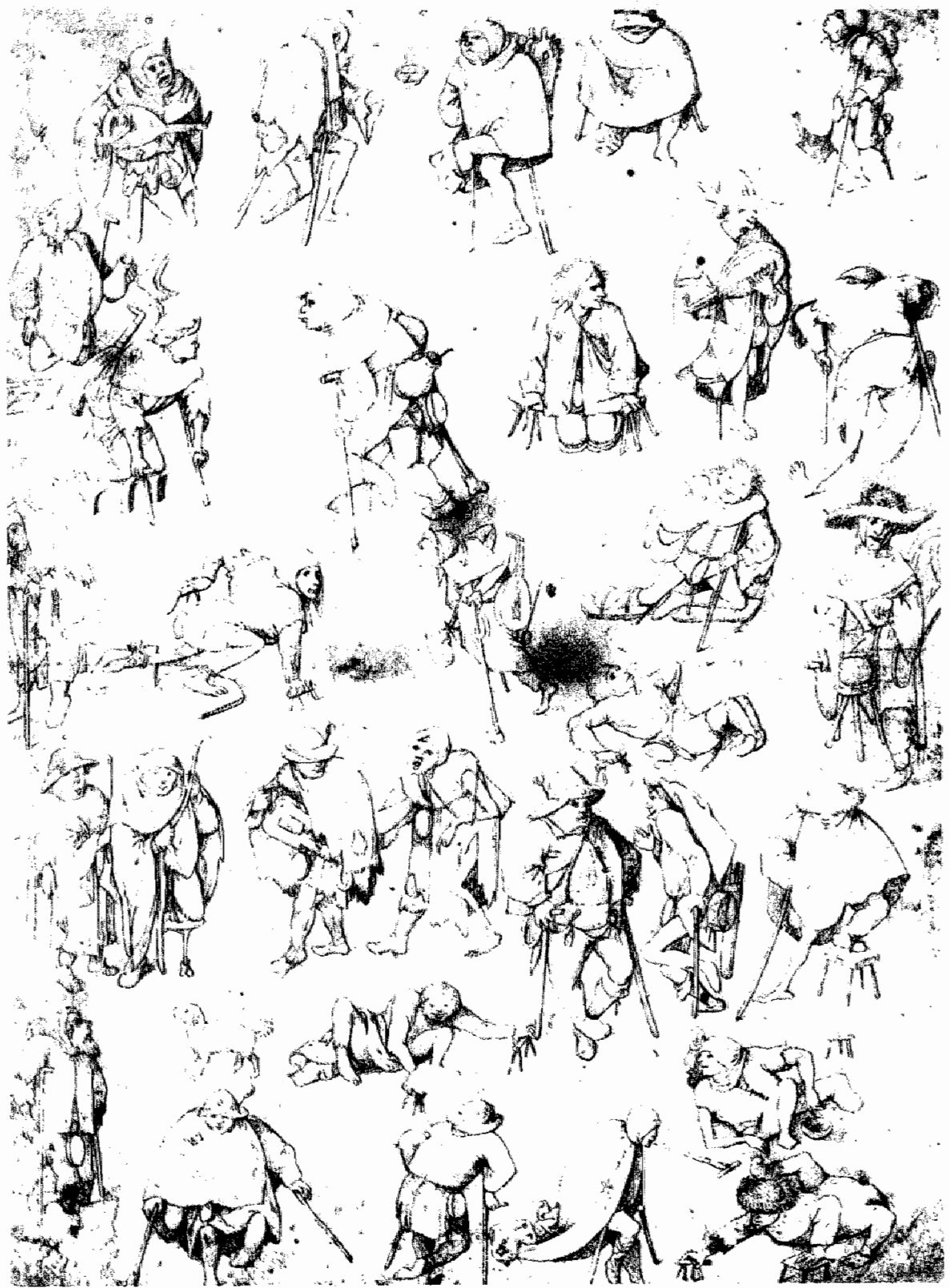

Fig. 3: Bedelaars (Jheronimus Bosch). 
werden inniger genoten, want zij staken nog feller af dan nu bij de jammerende armoede en verworpenheid. Een bonten tabbert, een helder haardvuur, dronk en scherts en een zacht bed hadden nog dat hoge genotsgehalte: En al de dingen des levens hadden een pronkende en gruwelijke openbaarheid. De leprozen klepten met hun ratel en hielden ommetochten, de bedelaars jammerden in de kerken en stalden er hun wanstaltigheid uit. Door het voortdurend contrast, door de bonte vormen, waarmee alles zich aan den geest opdrong, ging er van dat alledaagse een prikkeling, een hartstochtelijke suggestie uit, welke zich openbaart in de wankele stemming van ruwe uitgelatenheid, hevige wreedheid, innige vertedering, waartussen het Middeleeuwse stadsbeeld zich beweegt".

Waar Huizinga dit beeld weet op te roepen uit de Middeleeuwse kronieken laten de schilders Brueghel en Bosch, als fotografen van hun tijd, deze Middeleeuwse wereld zien. (Fig. 3)

Het schilderstuk van Brueghel, waar de Vasten als persoonlijke figuur optrekt tegen het heir van Vastenavond, toont ons een Middeleeuws marktplein, in die tijd toen Brussel nog een bruisende stad was. Onder de feestgangers ontdekken we een groepje gehandicapten, dat volkomen geïsoleerd staat ten opzichte van deze turbulente samenleving. Verdwaasd en angstig kijken zij ons aan en waar in onze tijd nog valak een aversie bestaat tegen een mismaakte, kunnen wij ons voorstellen hoe ellendig hun leven verlopen moet zijn. Een leven, steeds vergezeld van bedelnap en mogelijk naastenliefde. Mogelijk naastenliefde, want laten we terugkeren naar Huizinga (1957): ,, De bedelaars waren in het einde der Middeleeuwen een ontzettende plaag geworden. In de kerken krioelde een jammerlijke menigte en belette den dienst met hun geschreeuw en gedruis; onder hen was veel kwaad wolk, 'Validi mendicantes'. Het kapittel van Notre Dame te Parijs tracht in 1428 tevergeefs hen naar de kerkdeuren te verwijderen, en slaagt er slechts later in hen althans uit het koor naar het schip der kerk te verwijzen. Deschamps wordt niet moede, zijn haat tegen die ellendigen te luchten; hij scheert hen allen over een kam als huichelaars en bedriegers: ranselt hen de kerk uit, hangt ze op of verbrandt ze!" De chronisch zieke en mismaakte mens werd tot speelbal van deze samenleving, hoe hoog hij voorheen ook stond in maatschappelijk aanzien.

Met Brueghel en Huizinga werd getracht een beeld op te roepen van de mismaakte mens uit vroeger eeuwen, een uitgestotene uit de samenleving. Prothesevoorziening was meestal niet te realiseren omdat de prothesemaker, welke vaak ook chirurgijn was, in krijgsdienst werkte zodat alleen soldaat en edelman voor prothesevoorziening in aanmerking kwamen.

Ook de amputatietechniek liet te wensen over. Zonder gebruik te maken van een tourmiquet werd, na amputatie, bloedstelping bereikt door middel van kokende olie of met behulp van brandijzers. Aan de Fransman Ambroise Paré (1517-1590) is een hernieuwde belangstelling te danken voor de amputatietechniek. (Fig. 4) $\mathrm{Na}$ een leerschool bij een barbier, verwierf hij zich verder klinische kennis in het Hôtel Dieu te Parijs. Zijn grootste verdienste is het weer invoeren van de ligatuur als middel tot bloedstelping in het jaar 1552. Deze methode was al bekend toen Alexandrië een der wereldsteden was, maar werd in de late Middeleeuwen onder Arabische invloed vervangen door het veel minder betrouwbare brandijzer. Daarnaast amputeerde Paré, in 


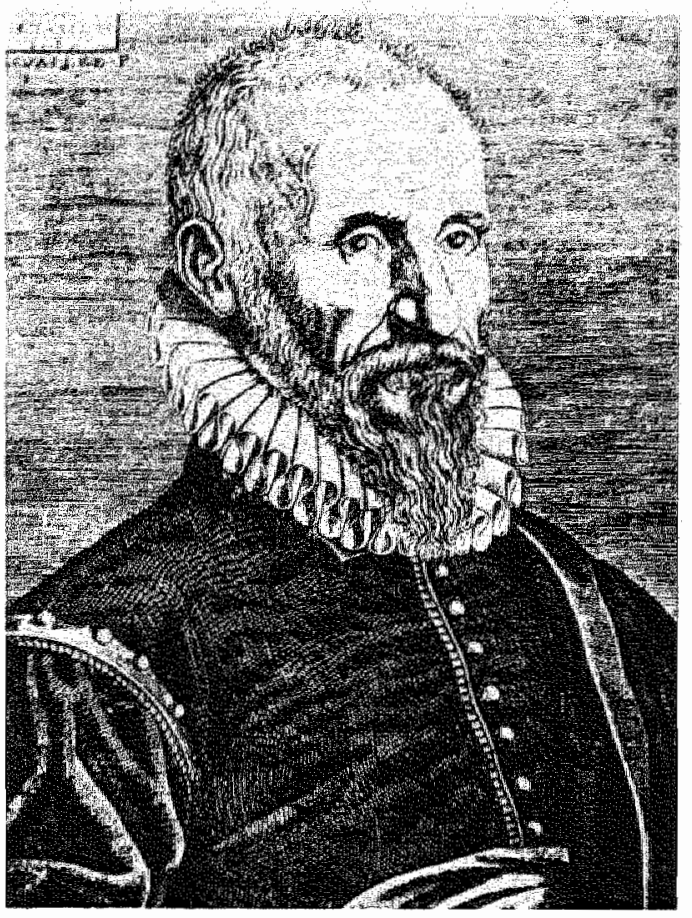

Fig. 4:

Ambroise Paré (1517 - 1590).

tegenstelling tot veel van zijn collegae, in het gezonde en niet in het afgestoryen deel der extremiteit. (Friedmann 1973, Breslau 1956 en Dederich 1970.) De Doctores Medicinae zagen in de chirurgijn geen collega. In andere zin dan destijds kan men nu stellen dat, in een tijd waarin Paré zich daadwerkelijk inzette voor de zieke mens, de Doctor Medicinae zich soms onlledig hield met piskijken, waardoor een vergelijking met de chirurgijn inderdaad onmogelijk is.

Ook maakte Paré diverse ontwerpen voor prothesen. Een door hem ontworpen kunstbeen voor een bovenbeengeamputeerde woog $7 \mathrm{~kg}$. Deze prothese was door middel van riemen aan een soort borstrok bevestigd. Voor de eerste mat in de geschiedenis werd gebruik gemaakt van kniescharnieren, waardoor flexiemogelijkheid ontstond,terwijl met behulp van een verende voetplaat een enkelfunctie werd nagebootst. (Breslau 1956 en Dederich 1970.) De invloed der wapensmeden bij deze prothesebouw is onmiskenbaar. Paré had ook een instrumentmaker in dienst, waarvan wij alleen nog de bijnatam kennen: „Der kleine Lotharinger”. (Friedmann 1973 en Dederich 1970.)

In ons land moet aan Pieter Adriaanz. Verduijn een eervolle plaats toegekend worden. In 1697 schreef hij zijn dissertatie over een nieuwe amputatietechniek. Bij beenamputaties maakte hij gebruik van een lange dorsale huidspierlap om het stompuiteinde te bedekken. Karthaus (1973) beschrijft het vormvaste stompverband dat Verduijn postoperatief aanwendde, waardoor betere wondgenezing dan voorheen bereikt werd.

In 1816 werd door James Potts in Londen hout gebruikt bij de prothese- 


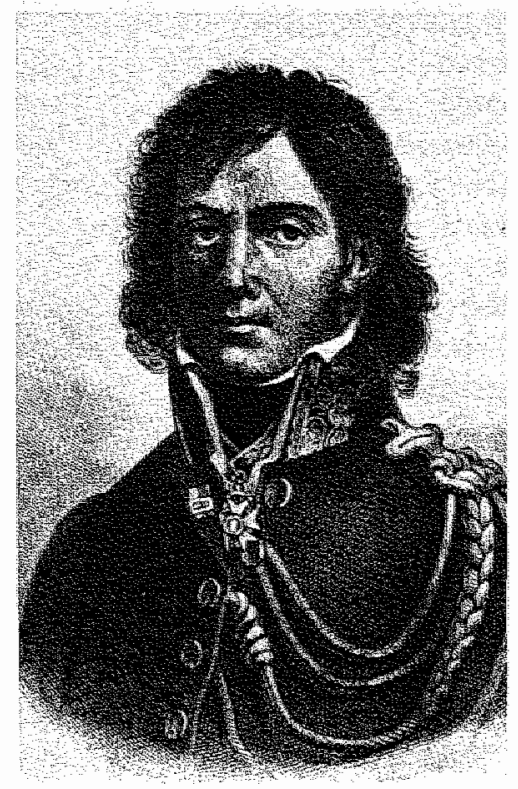

Fig. 5: Jean Dominique Baron Larrey (1766 - 1842).

bouw, in tegenstelling tot de tot dan toe gebruikte materialen: metaal of leer. De prothese was voorzien van kunstmatige pezen, die knie en enkel met elkaar verbonden en waarbij knieflexie gecombineerd werd met dorsaalflexie van de enkel. Beroemd werd dit houten kunstbeen ten dele omdat het gedragen werd door de markies van Anglesy, die zijn amputatie onderging tijdens de slag bij Waterloo. (Friedmann 1973.)

„Tijdens de Napoleontische tijd overvleugelde de figuur van Larrey (17661842) als lijfarts van Napoleon alle tijdgenoten. (Fig. 5) Hij organiseerde een snelle verzorging van de gewonden op het slagveld, verrichtte honderden amputaties tijdens de slag en boekte successen, zoals zij tot die tijd nog niet bekend waren. Hierbij kwam het meer aan op de behendigheid van de chirurg dan op de zekerheid der wondgenezing, aangezien anti- en aseptische behandeling ook toen nog onbekende begrippen waren. Ook was een goede stompbedekking, ondanks kundige amputatietechniek, niet te bereiken daar het vrijwel nooit tot een primaire wondgenezing kwam." (Breslau 1956.)

Treue (1956) geeft van het bovenstaande een indringende beschrijving: , Na de slag bij Asperen verrichtte Larrey een van zijn wereldberoemde en tot op de huidige dag bewonderde operaties. Maarschalk Lannes werd door een zwaar projectiel zo hevig aan de rechter knie gewond, dat Larrey geen andere mogelijkheid zag het been af te zetten, terwijl andere artsen tussen amputatie en conservatieve behandeling aarzelden. Een operatie was bij het hete weer overigens zeer gewaagd. Tenslotte bleek dat alle chirurgen voor operatie opkwamen, maar dat niemand haar zelf wilde uitvoeren, daar men 
een goede afloop nauwelijks mogelijk achtte. Larrey aarzelde -, niet omdat hij de verantwoordelijkheid schuwde, maar omdat het eigenlijk zijn plicht was de vele soldaten op het slagveld bij te staan en niet hier te opereren, waar reeds een vrij groot aantal artsen verzameld was. Tenslotte besloot hij tot de operatie en volbracht de operatie in nog geen twee minuten. Negen dagen later stierf de maarschalk echter aan sepsis, waartegen ook de grote arts geen middel kende".

Breslau (1956) stelt: ",Ingrijpende verandering in de prothesebouw vond plaats tijdens en na de Amerikaanse Burgeroorlog (1861-1865) toen men, gedwongen door het grote aantal slachtoffers besloot nieuwe wegen in te slaan. Meer dan tienduizend amputaties werden in deze burgeroorlog verricht en in 1873 waren voor de oorlogsgewonden 3111 arm-en 5894 beenprothesen vervaardigd".

De moderne prothesiologie nam echter een grote vlucht na de Eerste en Tweede Wereldoorlog. In Engeland werd in de Eerste Wereldoorlog het nationale Limb Fitting Service centrum opgericht. Ook werd in Duitsland de prothesebouw in belangrijke mate gestimuleerd. Veel van de toen ontwikkelde constructies en ideeën zijn voor de tegenwoordige techniek op dit gebied nog richtinggevend, waarbij 0 .a. Zur Verth, Kreutz, Lange en Waterman een belangrijke bijdrage geleverd hebben. Operatietechnieken, amputatieniveau's, belastbaarheid van de amputatiestomp en prothesebouw hadden in de eerste decennia van de twintigste eeuw hun volledige aandacht. Hoe groot de invloed van hen was, moge blijken uit een citaat van Dederich (1970):

,.Sie teilten die Gliedmassenabschnitte in wertvolle, minder wertvolle, unwichtige und hinderliche Abschnitte ein und schlugen Amputationen am Ort der Wahl vor. In starrer Anwendung dieser Amputationsschemen wurden sicherlich im zweiten Weltkrieg zahlose wertvolle Glied massenabschnitte bei der primären Amputation im Frontgebiet geopfert. Es gehört zu den großen Verdiensten von Kirschner, während des zweiten Weltkrieges diese in jeder Truppensanitätsausrüstung zu findenden Amputationsschemen außer Kraft gesetzt und wiederum nur die sparsamste und einfachts mögliche Amputation im Frontgebiet gefordert zu haben".

Na de Tweede Wereldoorlog dwongen bepaalde veranderingen in de maatschappij tot een hernieuwde aandacht voor de amputatieproblematiek:

a. De toegenomen verkeersdichtheid, die jaarlijks tot meer verkeerstraumata leidt.

b. De vergrijzing der bevolking, (mede door toedoen van de geneeskunde) waardoor ziektebeelden zoals atherosclerose, thrombose en embolie alsmede de late gevolgen van diabetes mellitus steeds meer voorkomen.

De ontdekking en verdere ontwikkeling van antibiotica alsmede verbeterde narcosetechnieken droegen mede bij tot een uitbreiding van de operatieve mogelijkheden, ook bij te amputeren patiënten. Ontwikkeling en vooruitgang op technisch terrein leverden differentiatie in materialen, waardoor functioneel verbeterde prothesen kunnen worden toegepast, welke ook in gewicht beduidend zijn verminderd. Tenslotte heeft de Industriële Revolutie ruim een eeuw geleden, ook het beeld van de indicaties tot amputatie gewijzigd. 
Van chirurgische zijde is langzaam een kentering te bespeuren met betrekking tot de amputatieproblematiek. Voorheen kwam het regelmatig voor dat een chirurg, na een amputatie verricht te hebben, de geamputeerde al of niet verwees naar een instrumentmaker ergens in den lande, die werkte naar eigen inzicht zonder kennis van conditie en belastingsmogelijkheden. Het was geen uitzondering als de geamputeerde de prothese al of niet per post kreeg thuis bezorgd en maar moest zien wat hij er mee deed. In het gunstigste geval werd dan via huisarts of chirurg een fysiotherapeut ingeschakeld, die een looptraining begon zonder overleg met de instrumentmaker en met de chirurg. Dat veel prothesen op deze manier op de rommelzolder belandden, hoeft verder geen betoog. Tegenwoordig wordt het steeds meer gebruikelijk dat in de grote revalidatie-centra ook voor geamputeerden diverse disciplines in natue samenwerking met elkaar hun deskundigheid inbrengen om de gehandicapte mens, na een zo goed mogelijke revalidatie, terug te laten keren in de maat schappij.

De geamputeerde staat in een modern centrum centraal in een team bestaande uit chirurg, prothesioloog, eventueel hart- longspecialist, psycholoog, fysiotherapeut, ergotherapeut, maatschappelijk werkende, verpleegkundige en last but not least de prothesemaker. Men streeft ernaar om pre-operatief de patiënt al bekend te maken met de werkwijze van dit team en in overleg met de chirurg te besluiten hoe en op welk niveau de amputatie zal moeten plaatsvinden. Immers, hoe het niveau van de restcapaciteiten zal zijn wordt primair bepaald door de operateur. Wanneer deze de amputatie ziet als het verwijderen van niet vitaal weefsel, gevolgd door stompsluiting, dan is een optimale revalidatie zonder meer onmogelijk geworden. De operateur die hier niet van doordrongen is, dient zich van amputaties te onthouden. Hij zal zich moeten realiseren dat hij de beginschakel is van een keten mensen en factoren, die de geamputeerde blijvend zal hebben te begeleiden. Van zeer weinig andere chirurgische ingrepen kan dit gezegd worden. Het eindresultaat van de samenwerking tussen chirurg en revalidatie-team moet zijn een patiënt, die zijn prothese niet beschouwt als een verlengstuk van zijn amputatiestomp, maar in staat gesteld werd de prothese te kunnen integreren in zijn lichaamsschema.

Ook ten aanzien van de amputatietechniek hebben zich de laatste decennia wijzigingen voorgedaan. ,Alleen al door oorlogsgeweld werden in de Tweede Wereldoorlog \pm 1.000 .000 mensen geamputeerd. 450.000 hiervan waren afkomstig uit de Deutsche Bundesrepublik en uit West Berlijn". (Dederich 1973.) Amerika moest rekening houden met 18.000 amputaties ten gevolge van oorlogshandelingen. Mede hierdoor is in Duitsland en in Amerika als ook in Engeland een organisatie opgebouwd "die beter dan in ons land zich bezighoudt met de amputatiepatiënten en hun problemen in de meest uitgebreide zin.

Op deze plaats lijkt het juist te vermelden dat uit deze nationale organisaties in diverse landen I.S.P.O. is voortgekomen, waarvan de hoofdzetel zich bevindt in Kopenhagen. I.S.P.O. (International Society for Prosthetics and Orthotics) stelt in de inleiding van haar statuten dat zij werd opgericht: ,,in order to promote high quality orthotic and prosthetic care of all people with 
neuromuscular and skeletal disabilities". Nederland is sinds 1972 lid van deze wereldomspannende organisatie.

De geamputeerde met een pijnloze stomp is meestal een onopvallend lid van onze samenleving. De patiënt mett stompklachten wordt juist door de pijn uit het normale ritme wan alledag gehaald. Door herhaaldelijk ziekteverzuim, met als gevolg hiervan een vaak wisselende arbeidsopstelling daalt in vele gevallen het sociale niveau. Het ligt voor de hand dat in de huidige economische erisis bij deze problemen niet alleen de patiënt maar ook zijn milieu betrokken is. Dederich (1973) uit Bonn verrichtte sedert 1955 ruim 2400 amputaties en myoplastische stompcorrecties. $25 \%$ Hiervan waren primaire amputaties, de overige $75 \%$ stompcorrecties. Voordat het tot de myoplastische correctie kwam was het gehele scala van therapeutische mogelijkheden op de patiënt uitgeprobeerd. Dit scala loopt van steeds sterker wordende analgetica, eventueel hypnose tot recidiverende operaties, welke zelfs in cerebro verricht werden om de patiënt te cureren. Helpt dit alles niet, dan komt de patiënt terecht bij de psycholoog of de psychiater die de oorzaak van de klachten in de persoonlijkheidsstructuur gaan zoeken, alsof zegt Dederich (1973): „Der Krieg nur Psychopaten amputiert hätte". Pijn is kwallitatief noch kwantitatief goed te omschrijven. Dit geldt temeer voor de geamputeerde, waarbij het amputatietrauma duidelijk een psychisch effect heeft en hierdoor de somatische pijn weer beinvloed wordt. Nog te vaak wordt dit gegeven gebruikt om tekorten in de amputatietechniek of prothesevoorziening af te schuiven op de patiënt. ,Is het niet logischer" zegt Dederich , te veronderstellen dat de pijn ontstaat ten gevolge van de operatie en dat het voortbestaan van die pijn de insufficiëntie van onze therapie bewijst". De conclusie ligt dan voor de hand dat men de operatietechniek moet verbeteren en niet de oorzaak moet zoeken in een psycholabiele persoonlijkheidsstructuur van de patiënt zoals nog maar al te vaak gebeurt.

Bij amputatieschemata, die vroeger gehanteerd werden door operateurs als Zur Verth, Kreutz, Lange en Waterman, was alleen de stomplengte de indicator waarop decennia lang beoordeeld werd of de stomp goed was. (Fig. 6) (Dederich 1970.) Chirurgen als Lisfranc en Chopart, Pirogoff en Syme hebben zelfs aan een exacte lengte van de amputatiestomp hun naam verbonden. De weke delen speelden nauwelijks een rol ofschoon deze het merendeel van de stompdiameter uitmaken. Wordt deze spierpomp echter verontachtzaamd, dan liggen de veneuze stuwingen op de loer. Via de hierdoor ontstane anoxie van binnenuit, alsmede de druk van de stompkoker komt het snel tot een stompulcus. De laatste decennia heeft men meer belangstelling gekregen voor de stofwisseling in de amputatiestomp. Er heeft een verschuiving plaatsgehad van hefboomproblemen naar circulatiefysiologie.

Men streeft tegenwoordig naar een pijnloze, musculeuze stomp met een goede doorbloeding. Waar het merendeel der amputaties momenteel gebeurt vanwege vasculaire insufficiëntie, is het duidelijk dat het vaststellen van de exacte grens voor amputatie dan moeilijk kan zijn. Ondanks arteriografie, oscillografie, phlethysmografie, huidtemperatuurmeting, etc. valt de defini- 


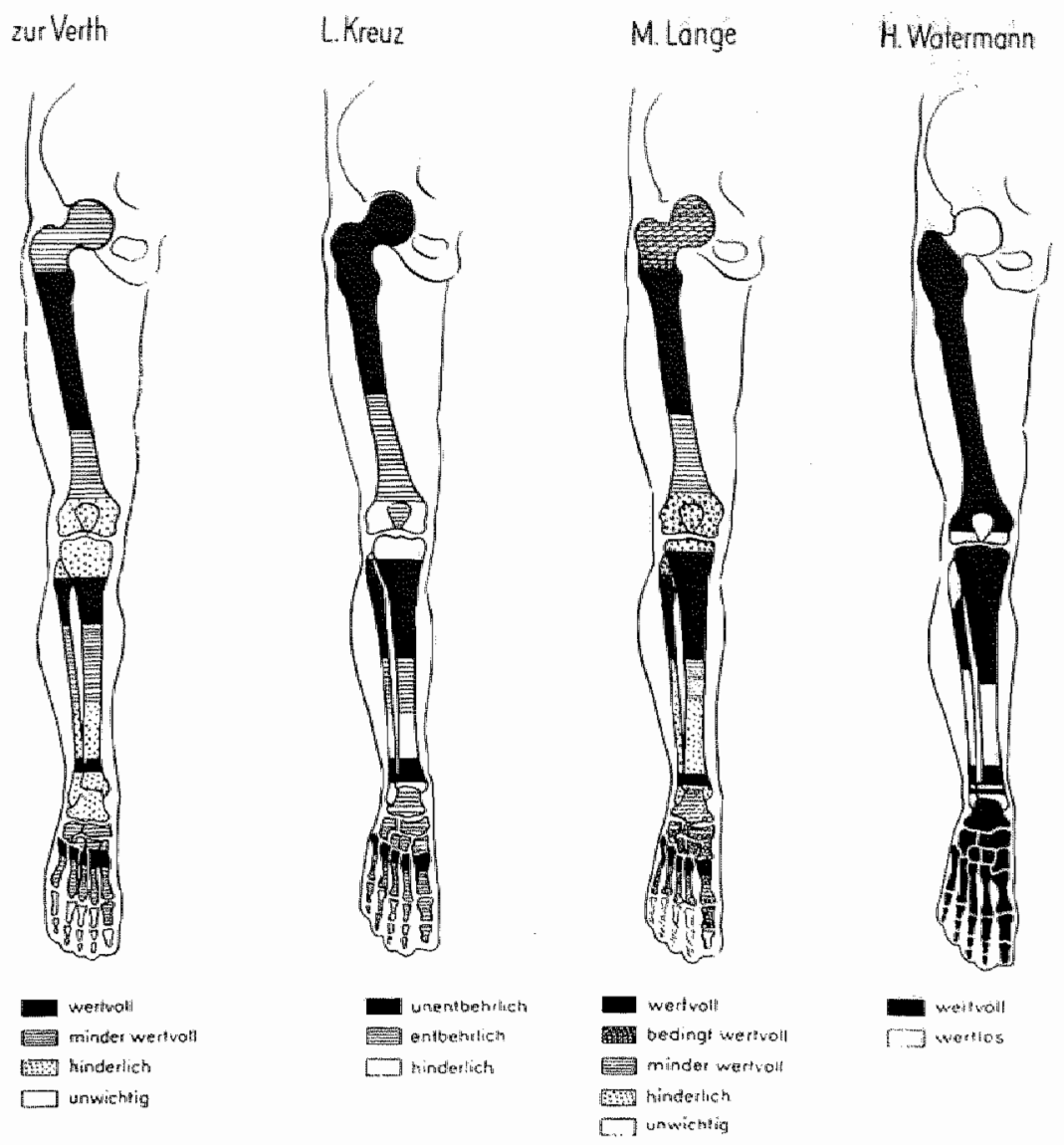

Fig. 6: Amputatieschema rand de eeuwwisseling.

tieve beslissing ten aanzien van het amputatieniveau pas, en dit terecht, tijdens de operatie. Dat naast deze algemene ook praktische overwegingen een rol spelen met betrekking tot de minimale en optimale stomplengte is voor de prothesemaker belangrijk.

De guillotinemethode zoals die vroeger bekend was, komt tegenwoordig alleen nog maar in aanmerking bij de bad-risk patiënt, als levensreddende maatregel bij ongunstige omstandigheden en als eventueel eerste begin van een plastische operatie. Bij de guillotinemethode werd dan een tricot zwachtel gebruikt om, na bevestiging met mastisol aan de huid een lichte tractie te kunnen uitoefenen om de retractie van huid en musculatuur zoveel mogelijk te voorkomen. Aangezien dit vaak niet lukte en allerlei complicaties het gevolg hiervan waren ging men zoekeri naar andere technieken orn vorm en kwaliteit van de stomp te beïnvloeden. Zo ontstond de bekende visbektechniek. Volgens Dederich (1970) werd deze al beschreven door Lowdarn tegen het einde van de $17 \mathrm{e}$ eeuw. Lowdarn zou als eerste een primaire wondsluiting nagestreefd hebben. Toch blewen deze technieken het nadeel behouden dat 
door retractie der musculatuur a- en antagonisten geen functionele eenheid meer met elkaar vormden, voorál waar men vroeger veel meer aandacht had voor het sluiten van de huid.

In de vijftiger jaren onderzocht Weiss (1960) bij geamputeerden het gedrag van de stompmusculatuur. Wanneer spierweefsel in bepaalde omstandigheden alleen maar isometrisch kan contraheren, bijvoorbeeld ten gevolge van een gipsverband of een ankylosis der aangrenzende gewrichten, dan blijkt na gerichte oefentherapie gedurende een zekere termijn een duidelijke toename van de electromyografische activiteit en verbetering van de spiertonus. Wanneer echter spierweefsel, ten gevolge van niet optimale amputatietechniek kan retraheren en daarmee zijn perifere insertie verliest, zijn alleen maar isotonische contracties mogelijk. Ondanks lang voortgezette en gerichte oefentherapie, treedt dan juist een daling op der electromyografische activiteit. Deze spieratrofie heeft dan tot gevolg het mogelijk ontstaan van contracturen, trofische storingen van de huid en demineralisatie van het botweefsel. Dat een amputatiestomp met bovengenoemde afwijkingen niet optimaal is voor de patiënt om te belasten en evenmin voor de prothesemaker staat buiten kijf. Duidelijk toonde Weiss $(1967,1973)$ het grote belang aan van de moderne myoplastiek en myodese technieken. De conclusie uit deze onderzoeken is dan ook dat bij amputatie de belangrijkste antagonistische spieren aan het botuiteinde of aan elkaar gefixeerd moeten worden. Deze spieren zijn namelijk van essentieel belang voor de propriocepsis. Het normale voortbewegingspatroon wordt hierdoor zo goed mogelijk behouden. , Bij de conventionele amputatietechniek worden de proprioceptieve elementen in pees en spieren niet gestimuleerd. Duidelijk is dat de proprioceptieve informatie na amputatie verminderd is ten opzichte van een normale extremiteit ten gevolge van het verlies van de voet. Maar verminderde proprioceptieve informatie is beter dan het geheel ontbreken ervan. Door de gelijktijdige ontwikkeling van de zogenaamde total contactprothese alsmede de zuigprothese wordt bovendien de relatie tussen amputatiestomp en prothese geintensiveerd, waardoor maximaal beschikbare proprioceptieve informatie wordt benut" aldus Karthaus (1973) in zijn uitgebreide beschrijving van deze myoplastische en myodese techniek voor de diverse amputatieniveau's van de onderste extremiteiten.

Ongeveer gelijk met deze nieuwe opvatting ten aanzien van de amputatietechniek is de zogenaamde ,,immediate fitting" of , sofort prothesetechniek" ontwikkeld.

Rond de eeuwwisseling heeft de Duitse chirurg Bier al pogingen hiertoe aangewend. (Dederich 1970, 1973.) Deze pogingen waren echter niet erg succesvol, ondermeer omdat men van een te star gipsverband gebruik maakte. De moderne ,,immediate fitting" begint bij Berlemont (1966) in 1957. Weiss (1971) nam de methode van Berlemont over in 1962. In Engeland was het Vitalie (1967) die over een reeks patiënten berichtte. Tenslotte was het in Amerika vooral Burgess (1971, 1973) die deze nieuwe methode in zijn land propageerde.

De gedachte die aan de "immediate fitting" ten grondslag ligt, is het 
voorkomen van postoperatief oedeen. Immers, bi een amputatie van een extremiteit wordt alle weefsel doorsneden, waardoor een terminale wond ontstaat. Door het araneggen van een gipssocket, zoals bedoetd bijde. .immedate fiting" , wordt het amputatiegebied onderworpen aan optimale dnkgradienten die het ontstan van oedeem legengatan. de circulatie ondersteunen en de ontstekingsreacties tot een minimum terugbrengen. (Fig. 7) Ahoewel men bij het aanleggen van een dergelijke ,immediate fung" verschit lende technieken kent, heeft deze primair tot doel een beperking van het postoperatieve oedeen. Hiermede bereikt men een verbeterde circulatie in de stomp. Hierdoor bevordert men de spieraktie in de stompmusculatuur; waardoor de stomp sneler zin definitieve vom zal bereiken. Na het annleggen var deze gipssocket kan de patiênt zich met minder pijn dan voorheen comfortabeler bewegen in bed of in de stoel. Op voornoemde wijze of door aktieve oefentherapie word een betere voeding van de stomp berelkt dan voorheen met als gevolg een snellere genezing. Door de pinvermindering, bij overigens gewaarborgde optimale drukkrachten op de stomp, is een snellere mobilisatie mogelijk. De patient ervart door de socket de krachten welke op de extremiteit werken zodat de propriocepsis gecontinueerd blift. Het was natuurlijk een grote vratag of een verse amputatiestomp deze belasting verdragen kon of dat er niet een groot aantal storingen in de wondgenezing zou optreden. Het bleek echter snel dat het merendeel der patienten als ook de amputatiestompen deze procedure ongewoon goed verdroegen. Dall deze "immediate fitting" met eventueel in aansluiting hieraan de definitieve prothese voor de psyche van de patient belangrijk is, is zonder meer duidelijk.

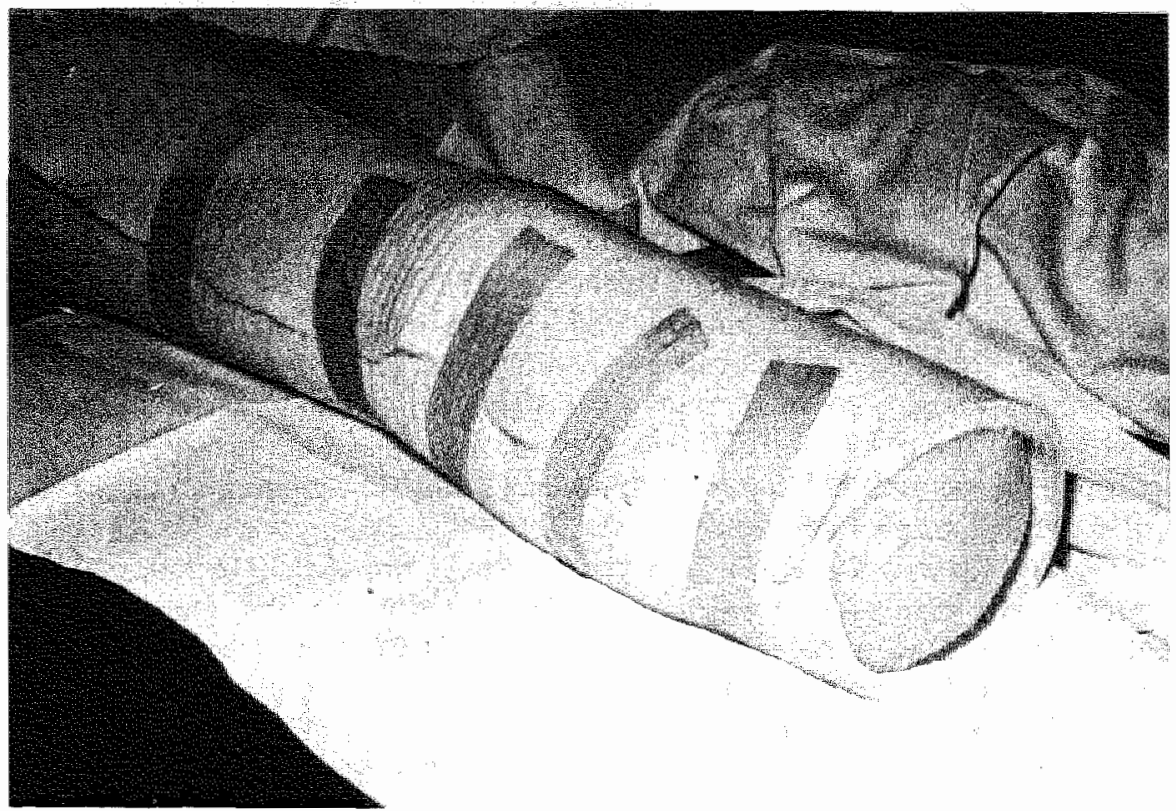

Fig. 7: Elastische inwendige koker bij toepassen van ,immediate fitting". 
De tegenstanders van deze methodiek voeren aan dat men door het aanleggen van een "immediate fitting" de wondgenezing niet van dag tot dag kan wolgen. Overigens, deze wens is zelden die wan een chirurg. Moberg, geciteerd door Dederich ( 1973 ) zei al: „Nichts dümmeres gibt es als den Wunsch eine Wunde täglich sehen zu wollen". Ook zonder visuele controle kan men een goede indruk krijgen hoe de wondgenezing verloopt. Algemeen welbevinden, ontbreken van pijn, goede nachtrust, ontbreken van temperatuur zijn evenzovele aanwijzingen van een ongestoorde wondgenezing. Ontstaat echter het tegendee, dan is er zeker indicatie aanwezig tot wondinspectie. Door de "immediate fitting" techniek met zijn snelle mobilisatie heeft de patiënt meer kans op een positieve instelling ten aanzien van de chirurgische ingreep, die een niet meer zo destructief karakter draagt. , Immediate fitting" staat of valt met de instelling van de chirurg voor wie een amputatie een plastisch reconstructieve ingreep moet betekenen en niet de hekkensluiter van het programma. Mogelijk dat de laatste opmerking toch de reden is geweest dat, ofschoon in diverse klinieken hoopvol met deze ,,immediate fitting" begonnen werd, men deze techniek naderhand toch weer verlaten heeft. Ook andere factoren spelen hierbij een rol zoals bijvoorbeeld het feit dat in het algemeen de vaatchirurg uiteindelijk ook de chirurg is die de amputatie verricht. Het ligt voor de hand dat zijn instelling ten aanzien van de vaatreconstructie een andere is, dan wanneer na gedane zaken, jammer genoeg toch een amputatie verricht moet worden. Waar het aantal amputaties in een ziekenhuis gelukkig vele malen kleiner is dan bijvoorbeeld het aantal cholecystectomiën of de te behandelen fracturen, kan men zich voorstellen dat de chirurg in het eerste geval toch wat minder is ingesteld op de problemen van de patiënt dan bij de twee laatstgenoemde voorbeelden. Vergeleken met enkele decennia geleden, lijkt de operateur nu toch meer bereid om mee te werken met een revalidatieteam. Hij is zich er langzaam bewust van geworden dat hij de eerste schakel is in een keten van disciplines welke de geamputeerde moet begeleiden. Een keten blijkt zo sterk als zijn zwakste schakel.

Het is duidelijk dat, waar hoge eisen gesteld worden aan de amputatiestomp, ook het vervaardigen van een prothese geen sinecure is. Uiteindelijk dient stomp en prothese als één functionele eenheid gebruikt te kunnen worden met zo min mogelijk energetische belasting voor de patiënt. Wanneer iemand beschikt over het gebruik van beide benen, dan hoort bij een bepaalde loopsnelheid een bepaald energieverbruik. Na een beenamputatie is de wisselwerking tussen de twee onderste extremiteiten essentieel verstoord. Wanneer na een amputatie een persoon zich moet voortbewegen met behulp van krukken, dan wordt bij een veel lagere loopsnelheid dan voorheen veel meer energie verbruikt. De normale toestand wordt het meest benaderd door bijvoorbeeld iemand met een bovenbeenamputatie uit te rusten met een zuigprothese. Een steltprothese is dan in het nadeel gezien het feit dat meer energie voor de voortbeweging noodzakelijk is. Immers, de geamputeerde moet ofwel een circumductie uitvoeren of telkens zijn bekken aan de prothesekant optillen om het nadeel van de knie-afwezigheid te ontgaan. Pasvorm en uitlijning van een prothese zijn dan ook de problemen waarmee de instrumentmaker elke dag geconfronteerd wordt. Juist de directe samenwer- 
king tussen de prothesemaker en de andere leden van het team is een conditio sina qua non om tot een goed protheseresultaat te komen. Niet voor niets werd honderden jaren geleden Ambroise Pare in het spoor van de veldheren begeleid door "Der kleine Lotharinger".

Ook ten aanzien van geamputeerden is het nu een algemeen aanvaard feit dat de behandeling een multidisciplinaire is. Deze disciplines dienen in teamverband met elkaar samen te werken. De problemen waarvoor deze teamleden door de patiënt gesteld worden zijn zo typisch, dat specialisatie op dit terrein door elk der teamleden geen overbodige eis kan worden genoemd. Dit geheel overwegende, zou men kunnen concluderen dat de revalidatie van geamputeerden in het algemeen het beste kan gebeuren in een revalidatiecentrum. Wanneer men in willekeurige volgorde de teamleden, betrokken bij de revalidatie van een geamputeerde, de revue laat passeren dan is er na operateur en prothesemaker op de eerste plaats de fysiotherapeut.

Naar schatting zullen in Limburg per jaar tennaastebij 100 mensen een beenamputatie ondergaan. In de provincie Limburg werken ongeveer 550 fysiotherapeuten. Dit houdt in dat 1 op de 5 fysiotherapeuten gemiddeld 1 amputatiepatiënt per jaar voor zijn rekening zou kunnen nemen. Net zo min als een chirurg zijn maagulcus of zijn fractuur laat behandelen door een collega die dit jaarlijks slechts een enkele maal doet, net zo min mag men verwachten dat iemand na een amputatie genoegen zou moeten nemen met een fysiotherapeut, die zeer weinig ervaring heeft op het gebied van de looptraining van een prothesedrager. Het is wel duidelijk een zaak van de behandelend chirurg, zonodig in overleg met de revalidatie-arts, erop toe te zien dat in het algemeen ziekenhuis direct postoperatief onder leiding van een deskundig fysiotherapeut door juiste liggingen en oefeningen contracturen worden voorkomen. Telkens is er sprake van wisselwerking tussen de diverse disciplines. Zo is voor de chirurg ook belangrijk dat het succes van de prothesevoorziening en looptraining door de patiënt direct gekoppeld wordt aan de kwaliteit van de amputatiestomp en dus aan de chirurg die hem maakte. Omgekeerd, bij het mislukken van de prothesevoorziening en de looptraining komt meermalen bij de patiënt de gedachte op: „Ben ik wel goed geopereerd?" Dat in het algemeen ziekenhuis de daar eventueel aanwezige revalidatie-arts een zeer belangrijke taak heeft in de wisselwerking tussen operateur en revalidatieteam is iets wat nauwelijks opgemerkt hoeft te worden.

De volgende discipline is de ergotherapie. De gerichte oefentherapie met de prothese onder leiding van de fysiotherapeut wordt op de E.T.-afdeling voortgezet in minder op pathologie gerichte omstandigheden. Al knutselend, zagend, schavend, zittend, staand en lopend wordt de prothese geleidelijk geïntegreerd als een onmiskenbaar instrument voor alle mogelijke activiteiten. Van verlengstuk van de amputatiestomp wordt de prothese zo een geïntegreerd deel van het lichaamsschema. Ook komt de ergotherapie te staan voor een typische huishoudtraining met name bij vrouwen met beenamputaties. Waar in deze tijd van krappe arbeidsmarkt vaak een mannelijke geamputeerde niet meer aan het werk komt, is het zaak voor hem te zoeken naar een zinvolle dagtaak. Een en ander rekening houdend met het feit dat de zinvolle vrijetijdsbesteding en huishoudelijk werk met of zonder amputatie en 
prothese een geheel andere problematiek met zich mee brengt. Dat patiënten, welke een amputatie van een der onderste extremiteiten hebben ondergaan, behoefte hebben aan diverse aanpassingen in hun woning ligt voor de hand. Dat het geven van adviezen in deze de nodige kennis en ervaring vereist, is de afgelopen jaren zeer duidelijk gebleken. Waar het realiseren van deze aanpassingen vaak in verband met de financiering dient te geschieden in overleg met een groot aantal instanties, lijkt het overbodig erop te wijzen dat dit niet het terrein is, dat door n'importe welke ergotherapeut volledig kan worden overzien. Deze activiteiten zijn de afgelopen jaren zo veelomwattend geworden dat het creëren van een werkgroep , Voorzieningen" in het Revalidatie Centrum ,Hoensbroeck" geen overbodige luxe was.

$\mathrm{Er}$ is weinig fantasie voor nodig om in te zien dat het opnieuw integreren van een geamputeerde in de huidige maatschappij problemen te over geeft voor een maatschappelijk werkende. Een beoefenaar van deze discipline heeft al een tijdrovende en vaak ondankbare taak, wanneer hij te maken heeft met mensen die niet zo'n ernstig verlies geleden hebben.

Ook de instelling van de verpleegkundige zal, in het kader van de revalidatie, een totaal andere moeten zijn dan wanneer deze geconfronteerd wordt met patiënten, die opgenomen zijn op bijvoorbeeld een chirurgische afdeling. Beide groepen van verpleegkundigen hebben, om hun werk zo optimaal mogelijk te kunnen doen, een aparte instelling nodig. Voor een verpleegkundige in een revalidatiecentrum houdt dit in: het systematisch onttrekken van hulp aan de revalidant of wel het zogenaamde ,,verplegen met de handen op de rug".

Als laatste teammedewerker is er de psycholoog, ook al is hij juist degene die vaak van meet af aan bij behandeling van geamputeerden in het revalidatieteam een zeer belangrijke rol speelt. Het valt niet te ontkennen dat in ons westers cultuurpatroon de lichaamsverheerlijking op alle mogelijke terreinen triomfen viert. Men kan stellen dat niemand van ons in staat is zich aan deze invloeden te onttrekken. Gezien in dit licht, ziet de psycholoog regelmatig dat een mens, geconfronteerd met het verlies van één of meer extremiteiten, reactiepatronen vertoont ten aanzien van dit verlies, die overeenkomen met die bij scheiding of verlies van een geliefd persoon. De diverse fasen in dit reactiepatroon zijn: de ontkenning, de agressie, het marchanderen, de depressie en de aanvaarding. (Kübler-Ross 1971.) Dat deze reacties aanmerkelijk duidelijker zullen optreden bij een traumatische amputatie, wil nog niet zeggen dat ze niet te onderkennen zouden zijn bij de bejaarde mens na een amputatie op grond van een vaatlijden. Bij de bejaarde mens zien we eveneens dat depressieve en agressieve verwerkingsreacties elkaar afwisselen. Soms lijkt het alsof bovengenoemde fasen zich helemaal niet voordoen. De patiënt klaagt en jammert niet; hij lijkt zich bij de situatie te hebben neergelegd. Dat wil dan echter nog niet zeggen dat het verlies verwerkt is. Vaak zijn de gevoelens dienaangaande slechts onderdrukt en daarom niet uiterlijk merkbaar. Van werkelijke aanvaarding kan pas sprake zijn als met protest, $k$ waadheid en verdriet van het verlorene afscheid is genomen. Dan pas heeft de mens zich van zijn verlies vrijgemaakt en kan hij zich gaan heroriënteren op zijn nieuwe levenssituatie. De begeleiding door de psycholoog in dit hele proces is een taak die niemand van hem kan overnemen. Bovendien is de 
psycholoog de aangewezen adviseur voor de andere disciplines van het revalidatieteam ten aanzien van de begeleiding van de geamputeerde en hun eigen reacties daarop. Pas wanneer bijvoorbeeld de prothesemaker weet, dat bepaalde klachten kunnen voortvloeien uit verwerkingsproblematiek en hij bij zichzelf zijn eigen irritatie en teleurstellingsgevoelens herkent omdat zijn „,kunstwerk" waaraan hij zo hard gewerkt heeft niet aanvaard wordt, pas dan zal hij misschien beter in staat zijn zich de verwijten van de patiënt niet persoonlijk aan te trekken. Het is de afgelopen jaren vaak gebleken hoe het slagen van een prothesevoorziening en looptraining met daarnaast de herintegratie in de maatschappij mede afhankelijk is van de (mede)behandeling c.q. begeleiding van de psycholoog.

Terugblikkend over de historie van de prothesiologie, kunnen we vaststellen dat eigenlijk zeer recent pas sprake is van een verbeterde opvang en behandeling van geamputeerden. Nogmaals: een ketting is zo sterk als de zwakste schakel. Deze schakels te laten functioneren in een sterke revalidatieketen kan alleen maar vruchten afwerpen voor deze specifieke groep chirurgische patiënten. Een amputatie is niet meer de afsluiting van een chirurgisch verloren zaak, maar het begin van een nieuwe, zij het andere toekomst voor de patiënt. Deze toekomst wordt niet bepaald door datgene dat de mens mist, maar door de capaciteiten die hij over heeft. 


\title{
Voor-en nazorg van geamputeerden.
}

\author{
„Amputation can and should be regarded \\ as part of a rehabilitation process".
}

De titel van dit hoofdstuk zou ook kunnen luiden: ,De taak van een revalidatie-centrum ten aanzien wan eerste- en tweede echelon van de gezondheidszorg".

Hierover bestaat nogal verschill van mening. Zo stelt Festen (1970) over het bestaansrecht van specifieke centra voor revalidatie: ,De totstandkoming van op zichzelfstaande revalidatie-centra als categorale ziekenhuizen dient niet te worden gestimuleerd". Naar zijn mening is men: ,, Met het stichten van categorale ziekenhuizen als een vorm van specialisatie in een ziekenhuistaak, in het verleden een weg opgegaan, waarvan men thans naar de mening van deskundigen zou moeten terugkeren. Het voortschrijdende multidisciplinaire karakter van de medisch- specialistische hulp eist een zo ver mogelijk doorgevoerde integratie van de totale hulpverlening. Wanneer het uit het oogpunt van medisch- wetenschappelijk onderzoek, ter beoordeling van de aandacht of voor het verkrijgen van bijzondere ervaring wenselijk is tot een zekere centralisatie en concentratie van behandelingsmogelijkheden van bepaalde ziektegevallen te komen (gedacht wordt hierbij aan dwarslaesiepatiënten), dan zou een dergelijk behandelingsstation toch een onderdeel dienen te zijn of minstens ten nauwste met een algemeen ziekenhuis moeten samenwerken. Dat geldt in het bijzonder voor de revalidatie, omdat daardoor bij alle afdelingen van het algemeen ziekenhuis de revalidatiegedachte levend blijft, terwijl anderzijds bij de revalidatie de noodzakelijke beïnvloeding door andere specialismen kan plaatsvinden". Nog stringenter werd dit in 1965 gezegd door Sarmiento (1965), toen hij zijn oude zienswijze aanhaalde:

, Rehabilitation is a vital part of orthopaedic surgery. Inherent in the very nature of our specialty is the preservation and the restoration of neuromusculoskeletal function by surgical as well nonsurgical methods. Therefore, it must follow that the orthopaedists are in a unique position to play the major role in any rehabilitation program, since the vast majority of all cripling and 
disabling diseases involve the neuromusculoskeletal system. It is the orthopaedic surgeon who, through background and training, is most knowledgeable in the areas of musculoskeletal anatomy, physiology, kinesiology, biomechanics, orthotics and prosthetics. It is peculiar then, that in spite of these qualifications, it was not the orthopaedist who assumed the leading role in rehabilitation following World War "I".

In hetzelfde artikel echter corrigeert Sarmiento zijn vroegere uitspraak. Hij moet vaststellen dat er een ontwikkeling heeft plaatsgevonden waarin naast de somatische aspecten ook de psychosociale problematiek rond een te revalideren patiënt alle aandacht verdient. Sarmiento vervolgt immers: , The interest of the physician should extend beyond the physical restoration of the patiënt and should include social, vocational and psychological restoration as well. This requires a team effort composed of medical and paramedical personnel specialised in various aspects of rehabilitation. It is not the position of the orthopaedist to be expert in all of these ancillary modalities, but it is his obligation as the most knowledgeable member of the team to guide and direct this over-all program leading to the ultimate restoration of the patiënt".

,Na de Tweede Wereldoorlog is in Nederland, min of meer geinspireerd door de ontwikkeling in Engeland de revalidatie-ontwikkeling pas goed op gang gekomen. De Nederlandse regering in Londen heeft in 1943 een commissie ingesteld, onder voorzitterschap van $\mathrm{Mr}$. Dr, van Rhijn, die in een rapport getuigde van de ingewikkelde problematiek van de revalidatie van verminderd arbeidsgeschikten". (VRIN: Vereniging Revalidatie Inrichtingen Nederland 1975.)

In deze naoorlogse jaren zijn overal ter wereld revalidatie-centra ontstaan of revalidatie-afdelingen, verbonden aan algemene ziekenhuizen. Met betrekking tot de geamputeerden constateert Sarmiento (1965): „Prior to this time... the amputee all to frequently was discharged, usually from the general surgery service, to be seen later with swollen stump, flexion contractures and weak musculature. An agressive postoperative preprosthetic periode of training is now possible".

Dat zelfs nog in de zestiger jaren geamputeerden ook in ons land meestal niet konden rekenen op een integrale hulpverlening is maar al te goed bekend.

Amputatie was voor de operateur het afsluiten van een chirurgisch verloren zaak. Te begrijpen is dit, wanneer men zich realiseert hoeveel moeite en inspanning een chirurgisch team zich getroostte, wanneer een extremiteit behouden moest blijven, getroffen door een vasculair lijden, een ernstige fractuur of een chronische osteomyelitis. Te verlangen dat de chirurg zich postoperatief zou opstellen als de leider van een revalidatieteam, is een wens die alleen maar geuit kan worden door iemand die het chirurgisch bedrijf nooit van dichtbij heeft meegemaakt. Ook Sarmiento (1965) benadrukt het belang van de totale patiëntenzorg: ,A total spectrum of patiënt care was brought into focus and the importance of the orthopaedist in the over-all picture of getting a patient well. It further made the resident more aware of the importance of ancillary medical and paramedical personnel and made clear that coördination of these various agencies was essential to restoring the patiënt to his position in society". 
,Coordination is essential to restoring the patient to his position in society" is de conditio sine qua non voor revalidatie en tegelijk de bottle-neck, waardoor, in een algemeen ziekenhuis onder leiding van de algemeen- dan wel orthopaedisch chirurg, de revalidatie van de geamputeerde niet optimaal kan verlopen. Een operateur die gemiddeld tien tot vijftien cholecystectomiën of maagresecties per jaar verricht, kan geen goede ervaring krijgen om deze patiënten optimaal te kunnen behandelen. Hoeveel te meer geldt dit dan voor de revalidatie van een geamputeerde, waar deze behandeling een multidisciplinair karakter heeft. Coördineren vooronderstelt toch op zijn minst dat men enigermate op de hoogte is met de werkwijze van de diverse disciplines, die betrokken zijn bij de revalidatie van een geamputeerde.

De fysiotherapie, mits op de juiste wijze geïndiceerd en toegepast, is een belangrijk onderdeel van een revalidatieplan na amputatie. De wet schrijft voor dat de arts een schriftelijke verklaring moet verstrekken met diagnose en gevraagde behandeling. De fysiotherapeut dient de behandelende arts op de hoogte te houden van het verloop. Nog steeds klagen de fysiotherapeuten dat voorschriften van huisarts of specialist niet of nauwelijks voldoen aan de voorwaarden in de wet gesteld. Contact over en weer ten aanzien van behandelingsverloop is vaak evenmin aanwezig. Zo ligt het voor de hand dat de arts nagenoeg geen inzicht kan krijgen in de mogelijkheden en de waarde van de fysiotherapie in het kader van het revalidatieplan ten behoeve van een geamputeerde. Mutatis mutandis geldt dit nog meer voor de orthopaedisch instrumentmaker of de ergotherapeut. De huisarts en ook menig chirurg heeft tijdens zijn opleiding nooit kennis kunnen of willen nemen van de taak en de werkwijze van deze disciplines. En niemand zal toch willen ontkennen dat de orthopaedische instrumentmakerij dan wel ergotherapie belangrijke onderdelen zouden zijn van het revalidatieproces na amputatie van een extremiteit.

Men zou mogen vaststellen dat, hoe belangrijk de chirurg als eerste in de revalidatieketen van een geamputeerde ook is, hij niet de behandeling kan voortzetten, maar deze over dient te dragen aan de arts die wel de mogelijkheid heeft of had zich breed te oriënteren op die terreinen, waar de disciplines, betrokken bij een amputatieteam, zich bewegen.

De vraag doet zich voor of de revalidatie-arts, werkzaam in een algemeen ziekenhuis, de eerst aangewezene zou moeten zijn om de coördinatie rond de behandeling na amputatie op zich te nemen. Immers, deze specialist is tijdens zijn opleiding eerder en meer in staat geweest kennis te nemen van de werkzaamheden van alle disciplines rond een revalidatiegebeuren. Daarnaast is hij geen orgaanspecialist, maar juist opgeleid om als coördinator, zowel intra- als extramuraal, de behandeling ter zake van een revalidatieproces te realiseren. De revalidatie-arts kan dus beter dan de orgaanspecialist de behandeling na amputatie overnemen.

Bij nadere beschouwing zijn echter tegen deze conclusie wel degelijk tegenargumenten aan te voeren. Onder andere zijn er problemen met betrekking tot de patiënt, die een revalidatie middels dagbehandeling toch wel minder ideaal, zo niet uiterst moeilijk maken.

Alle statistieken, althans in de Westerse landen, tonen aan dat de meeste amputaties plaatsvinden in de leeftijdsgroep van 60 tot 80 jaar.

Bij een revalidatie in dagbehandeling kan men zich dan afvragen: 
a. Wie verzorgt de patiënt na sluitingstijd van de polikliniek, waar de dagbehandeling plats vindt. Zo de eventuele huwelijkspartner nog in leven is, is deze meestal niet in staat de patiënt (in het begin nog niet ADL-zelfstandig) op te vangen. Men denke hierbij aan de dagelijkse lichaamshygiène, toiletgang, het beklimmen van de trap naar de slaapkamer, afwezig zijn van liften, het zwachtelen van de amputatiestomp, etc., etc. Om over de problemen van de alleenstaande geamputeerde na 6 uur "s avonds nog maar niet te spreken.

b. Wie zorgt gedurende de periode van dagbehandeling voor de rolstoel. Een bejaarde patiënt, die vaak weken tot maanden bedlegerig is geweest voor de amputatie een feit werd, is niet in staat te lopen met krukken, nog afgezien van het feit dat dit cardiaal een bijzonder zware belasting betekent. Het algemeen ziekenhuis of de kruisverenigingen rekenen het verschaffen van een rolstoel tot op heden niet tot hun taak.

c. Het is een ervaringsfeit dat de meest noodzakelijke huisaanpassingen voor een bejaarde patiënt, zoals beugels op het toilet of in de natte cel niet van de ene op de andere dag gerealiseerd worden. Dan geldt voor de bejaarde: beter een goede buur dan de verre verzorgingsstaat.

d. De jonge geamputeerde "komend uit het arbeidsproces, krijgt te maken met alle problemen voor een nieuw toekomstontwerp. Een toekomst die voor zijn leeftijdsgenoten, niet geamputeerd, al waak verre van rooskleurig is. Evaluatie van arbeidsmogelijkheden en de daadwerkelijke omscholing eist voorzieningen die het algemeen ziekenhuis niet tot de hare mag rekenen.

Dit overwegende is revalidatie in dagbehandeling èn voor de patiënt èn voor diens thuismilieu, zeker in het begin, een moeizaam verlopend proces.

Wanneer we vervolgens dagbehandeling in een algemeen ziekenhuis vergelijken met de werkwijze van een amputatieteam in een revalidatie-centrum, dan is het creëren van een apart team ten behoeve van geamputeerden in een algemeen ziekenhuis meestal geen haalbare zaak. Bij een totaal van tien tot vijftien amputaties in een middelgroot ziekenhuis, verspreid over een jaar, doen alle teamleden te weinig ervaring op, vergeleken met een amputatieteam van een revalidatie-centrum. Dit team in een algemeen ziekenhuis telkens opnieuw te formeren, wanneer een geamputeerde voor revalidatie wordt aangeboden, brengt toch wel moeilijkheden mee voor de therapieplanning ten aanzien van andere te revalideren patiënten in dagbehandeling.

Tenslotte is de dagelijkse aanwezigheid van de prothesemaker en de aanwezigheid van een goed geoutilleerde orthopaedische instrumentmakerij een niet te onderschatten voordeel in de werkwijze van een revalidatie-centrum. Meestal bezoekt de prothesemaker van een elders gevestigde instrumentmakerij éénmaal per week het algemeen ziekenhuis. Niet altijd kan dan ter plekke correctie of reparatie van een prothese plaatsvinden, zodat gedurende enige tijd de looptraining weer onderbroken wordt. Het dagelijks contact tussen de leden van een amputatieteam in een centrum en het daardoor snel kunnen bijsturen van het revalidatiebeleid is iets waar de patiënt alleen maar voordeel van heeft. 
Een geheel andere zaak is de vraag of bijvoorbeeld na een jaar, wanneer het complexe geheel van factoren, die een rol spelen in het gehele revalidatieproces hun beslag kregen in een zo goed mogelijk resultaat, de revalidatiearts in het ziekenhuis de controle van de prothesedrager niet zou kunnen overnemen. Is met deze controle de rol welke de revalidatie-arts kan spelen bij te revalideren patienten na amputatie omschreven? Dit is volstrekt niet het geval! Immers, Querido (1972) zegt in "Geneeskunst in Transcendentie": ,Als basis van de geneeskunst vinden we de hulpeloosheid van de mens, in de greep van zijn angsten en onzekerheden, die, zich vastklemmend aan de medemens, in hem de steun, de rust en de zekerheid hoopt te vinden, waarvan hij in zichzelf het tekortschieten ondervindt. Dit is, zo men wil, de mogelijke band tussen arts en patiënt zonder welke de geneeskunst niet bestaanbaar is en die er de eerste voorwaarde voor vormt".

Dit is bijzonder toepasbaar op de mens die een zo ernstige mutilatie van zijn lichaam moest ondergaan als bij een amputatie van een extremiteit het geval is. In het amphitheater van de Academie de Medicine te Parijs staat de volgende spreuk:

\section{Guerir parfois \\ Soulager souvent \\ Consoler toujours.}

De eerste opdracht wordt door elke arts begrepen en veelal als de voornaamste taak gezien. Hierdoor komt het ,,soulager" en ,consoler" wel eens in het gedrang. Hieraan herinnert Bremer (1972) wanneer hij opmerkt: ,, veel ziekenhuis-patiënten voelen zich tekort komen in informatie en uitleg over alles wat er met en rond hen heen gebeurt, terwijl zij zich veelal niet vrij voelen dat alles te vragen. Hoe groot ook de behoefte is aan meer gesprekscontact met hun dokter en verpleegsters, zij durven daar vaak geen beroep op te doen, bij voorbaat overtuigd dat die het toch al veel te druk hebben". Kortbeek (1976) zegt terecht: ,, De patiënt wil weten wat er aan de hand is, wil weten wat hem te wachten staat, heeft behoefte zijn hart te luchten, hoopvolle gezichtspunten te vernemen, steun en bemoediging te krijgen, het vertrouwen te hebben dat al het mogelijke wordt gedaan. Om het onvermijdelijke te kunnen a anvaarden en om een weg te vinden om zinvol verder te leven met medische beperkingen en lasten is moeilijk. Begeleiding wordt zo het bijstaan van de patiënt en zijn naasten in het verwerken van de ervaren stoornissen, beperkingen en bemoeienissen en zonodig ook het vinden van een weg om in de gewijzigde omstandigheden weer zichzelf te zijn. Begeleiding veronderstelt een relatie van persoon tot persoon, waarin de begeleider zich met de patiënt in diens situatie tracht te verplaatsen en behulpzaam te zijn om zichzelf te hervinden en tot een leefbaar en zinvol bestaan te komen".

De begeleiding van een patiënt, waarbij men voornemens is een amputatie van een lidmaat te verrichten, dient te beginnen op de heelkundige afdeling. Juist voor de revalidatie-arts, werkzaam in een algemeen ziekenhuis, is hier een belangrijke en dankbare taak weggelegd. Belangrijk, omdat de patiënt prae-operatief op de juiste wijze dient te worden benaderd en ook het recht heeft op een uitgebreide voorlichting omtrent datgene wat hem te wachten 
staat. Nog te vaak worden door niet deskundigen aan de patiënt beloften gedaan, die zelfs de beste revalidatie-centra niet waar kunnen maken. Zo ontstaan later teleurstelling en ondermijning van het vertrouwen in het amputatieteam. Op grond van zijn opleiding mag men veronderstellen dat de revalidatie-arts deze voorlichting wél deskundig kan geven. Deze voorlichting dient eerlijk te zijn, ook dan, wanneer de revalidatie-arts niet veel bieden. kan op grond van de conditie van de patiènt, alsmede de status localis van de geamputeerde extremiteit.

De samenwerking tussen chirurg en revalidatie-arts om deze prae- en postoperatieve begeleiding mogelijk te maken is van eminent belang. De chirurg die zichzelf, zoals elders betoogd, ziet als de eerste schakel van de gehele revalidatieketen zal weinig moeite hebben om de revalidatie-arts uit te nodigen de zorg voor de patiënt mede op zich te nemen. Chirurgen kennis te laten nemen van mogelijkheden en resultaten na amputatie van een extremiteit op prothesetechnisch terrein, alsmede andere revalidatie-aspecten, is een taak die het amputatieteam van het Revalidatie Centrum op zich genomen heeft.

1973 was een keerpunt in de prothesiologie in Zuid-Limburg, alsmede de zienswijze hieromtrent van het R.C.H. In de herfst van dat jaar werden alle chirurgen en hun assistenten van de ziekenhuizen in Zuid-Limburg uitgenodigd om met elkaar te overleggen hoe men, mogelijk beter dan voorheen, de belangen van geamputeerden zou kunnen behartigen. Onder meer sprak Karthaus over recente ontwikkelingen met betrekking tot de amputatietechnieken (myodese-myoplastiek) en de zogenaamde immediate fitting waarover elders gesproken wordt. Sindsdien zijn er regelmatig, éénmaal per jaar, contacten binnen het Revalidatie Centrum met alle algemeen chirurgen en de orthopaedisch chirurgen van Zuid- en Midden-Limburg. Enerzijds om een evaluatie te geven van behaalde resultaten, anderzijds om bestaande problemen betreffende geamputeerden te bespreken. Het gevolg hiervan is geweest dat de belangstelling voor amputatietechnieken en geamputeerden bij de chirurgen van Zuid- en Midden-Limburg groter is geworden en dat, los van bovengenoemde contacten, overleg plaats vindt omtrent individuele patiën ten.

Intussen zijn door diverse Zuid-Limburgse ziekenhuizen revalidatie-artsen aangetrokken, die hun bijdrage leveren in de samenwerking tussen operateurs en amputatieteam. Juist deze samenwerking is van essentieel belang* wil de taak opgedragen aan het amputatieteam van het R.C.H steeds zo optimaal mogelijk worden verricht.

In het bovenstaande werd er al op gezinspeeld dat de totstandkoming van revalidatie-centra ten behoeve van bepaalde categorieën patiënten wel degelijk zinvol is, zoals later uit de bespreking van behaalde resultaten moge blijken.

Men zou de conclusie kunnen trekken dat deze contacten met de chirurgen mogelijk zouden kunnen leiden tot een regionale behandeling van geamputeerden, gecentraliseerd in een revalidatiecentrum. Men kan dan aanvoeren dat de spreiding van revalidatie-centra in Nederland zodanig is, dat de afstand tussen de woonplaats en een revalidatie-centrum bezwaarlijk kan worden genoemd. In dat geval beveelt de VRIN (1975) aan: , dat de revalidatie 
dagbehandeling ook kan plaatswinden op een revalidatie-afdeling van een algemeen ziekenhuis, als deze afdeling beantwoordt aan de eisen, die de VRIN heeft neergelegd in haar schrijven aan de Minister van Volksgezondheid d.d. 27 maart 1972 en deze afdeling als zodanig door de Minister wordt erkend".

Terecht zegt de commissie dat deze substituut oplossing niet geldt voor de klinische revalidatie. Terecht, omdat de eisen, gesteld aan een ziekenhuisrevalidatie-afdeling in het VRIN-rapport zelfs niet altijd haalbaar zijn voor een klinisch revallidatie-centrum.

Overigens dient men te bedenken dat afstand soms weinig betekent voor een patiënt die persê meer valide wil worden. De recente Houstonbrug voor hartpatiënten is daar een duidelijk voorbeeld van.

Belangrijk is wel, dat, wil de klinische revalidatie een duidelijk omschreven plaats binnen de Nederlandse gezondheidszorg krijgen, uiterst nauwe contacten met het tweede echelon geboden zijn. Zowel de revalidatie-arts in een algemeen ziekenhuis als in het revalidatiecentrum hebben hier een taak te vervullen. Enerzijds kan dan de revalidatiegedachte in het algemeen ziekenhuis levend blijven, terwijl anderzijds bij de revalidatie de noodzakelijke beïnvloeding door andere specialismen en disciplines beter kan plaatsvinden.

\section{De nazorg.}

Mertens (1973) komt tot de volgende conclusie: , ,Het aantal patiënten dat na ontslag uit een algemeen ziekenhuis hulp nodig heeft van wijkverpleegkundigen neemt toe. Dit zijn patiënten, die dan nog verpleegkundige zorg nodig hebben, een bepaalde leefregel moeten volgen, (re)activering behoeven, hulp moeten hebben bij het aanpassen wan zichzelf en (of) hun omgeving aan hun ziek-zijn of aan hun handicap. Deze toeneming is een gevolg van de verandering van de bevolking, de toeneming van chronische ziekten en van invalidiserende operaties. De ervaring heeft geleerd dat deze hulp thuis aan de ontslagen patiënten die deze nodig hebben niet altijd, en lang niet altijd voldoende snel, geboden wordt. De reden hiervan is de gebrekkige - voornamelijk te trage - communicatie tussen specialist en huisarts en vervolgens tussen huisarts en verpleegkundige".

De geamputeerde, die na revalidatie als prothesedrager het centrum verlaat, heeft recht op de mogelijkheid tot nazorg, zo men wil voortgezette zorg. Zoals reeds eerder werd gesteld, behoort hij tot een kleine groep chirurgische patiënten die vaak voor de rest van hun leven regelmatig begeleiding nodig hebben.

150 tot 200 jaar geleden waren gezinszorg, bejaardenzorg, zuigelingenzorg, etc. onbekende begrippen. De wetten van Thorbecke, omtrent de eisen, te stellen aan de tot de uitoefening van de geneeskunst in haar volle omvang bevoegde geneeskundige dateren van 1865 . Tien jaar later, in 1875 volgt door het oprichten van de kruisverenigingen het begin van de professionalisering, ook in de verpleging. Deze professionalisering van onze gezondheidszorg raakte in een stroomversnelling tijdens de industriële revolutie. De kiem voor deze stroomversnelling was al gelegd door de Verlichting in de $18 \mathrm{e}$ eeuw. 
Door de onmiskenbare successen van de natuurwetenschappen werd ook de medicus meegesleurd. De ziekte werd zijn probleem. De zieke had afgedaan. Afscheid werd genomen van de Caritas, die eeuwenlang de belangrijkste prikkel was om ziekenzorg te bedrijven. Caritas: de waardering, de hoogachting en de daaruit voortvloeiende liefde voor de medemens. Deze Latijnse Caritas kreeg in de Christelijke naastenliefde een andere naam: de werken van barmhartigheid. De naakten kleden, de dorstigen laven, de hongerigen spijzen, etc. Dit testamentische woord werd door ieder begrepen en toegepast als een pakket zorg, waar de geneeskunde van de $18 \mathrm{e}$ eeuw soms geen boodschap meer aan had. De dorstigen laven is nu geworden en mogelijk soms verworden tot een zeer wetenschappelijke benadering, waar electrolyten en niet de zieke mens meer de hoofdrol spelen. De dorstigen laven is een professionele zaak geworden.

,,De zorg heeft zich in het kader van de 20e eeuw herschapen. Zij berust op wetenschappelijke gegevens en ze heeft zich ingevoegd in een arbeidsbestel, waardoor het een onderdeel van het economisch gebeuren is geworden. Daardoor is het karakter van de zorg veranderd, maar noch de zorggever, noch de zorgdrager zijn zich dit voldoende bewust. Hier ligt een bron van problemen en conflicten, die nog nauwelijks als zodanig onderkend wordt." (Leering 1976.)

, Het verzekeringswezen heeft de charitatieve instelling doen verdwijnen en vervangen door een zakelijke verhouding van recht, aanspraak en betaling, De verpleegkunde is een beroep geworden met opleiding, diploma en C.A.O. Natuurlijk is hier geen opzet in het spel, het gaat om een toedracht van feiten, die de geneeskunde zijn eenzijdigheid heeft bezorgd. Eenzijdigheden, die sinds kort zichtbaar worden zoals de eenzijdigheden van industrialisatie - ook een kind van de natuurwetenschappen - ons vandaag de dag duidelijk worden." (Thomas 1977.)

Langzaam dringt het besef door dat , de professionalisering van de hulpverlening met de specialisatie in het verlengde daarvan, in de welzijnszorg vaak ten koste gaat van een stuk solidariteit, beschikbaarheid en menselijke nabijheid. Teveel wordt nog uit het oog verloren dat hulpverlening persoongebonden is en dat de kwaliteit ervan staat of valt met de kwaliteit van de hulpverlener en niet met die van het gebouw, de organisatie of de financiering. De toenemende belangstelling voor de zogenaamde randgebieden van de geneeskunde, waar de intermenselijke relatie zo'n belangrijke rol speelt, is in dit opzicht niet alleen een waarschuwing maar tevens een aanwijzing waar onze tekorten liggen". (Festen 1977.)

Waar liggen onze tekorten? Onze successen zijn duidelijk afgebakend. Zij zijn beperkt tot het terrein van de acute aandoeningen. Daar behaalde de geneeskunde de laatste 11/2 eeuw haar grootste triomfen. Behandeling van infectieziekten, waarvan we voor het merendeel oorzaak en behandeling kennen. Acute buikchirurgie, operatieve fractuurbehandeling, behandeling van shock, re-animatie, etc.

De geneeskunde heeft echter veel minder te bieden aan patiënten met chronische aandoeningen of met verminderde validiteit. De aandacht voor de hieruit voortvloeiende psychosociale nood heeft geen gelijke tred gehouden met de eclatante successen. De deskundigheid in bovengenoemde successen 
wordt beward als een monopolie van de professie. Er ontstaat een vakjargon, dat ertoe bijdraagt dit monopolie te bestendigen. Er is niets nieuws onder de zon. Eeuwen geleden hadden priester en medicijnman eigen, goed bewaarde riten en geheimen, slechts onder bepaalde voorwaarden doorgegeven aan opvolgers. Hattinga-Verschure (1977) stelt: „, De ontsporing begint wanneer het professionele kader meent, op grond van opleiding en diploma's van de zorgverleners, hun status, de omvang van hun instellingen en salarissen etc., de enig geroepene te zijn om de gezondheidszorg op niveau te voltrekken".

De professionele werkers dienen meer aandacht te krijgen voor de zieke mens in plaats van de ziekte, meer aandacht voor de caritas in zijn oorspronkelijke betekenis dan voor de pathologische anatomie. ,De geneeskunde dient er aan herinnerd te worden", merkt Bremer (1972) op ,,dat niet de ziekte maar de zieke behandeling vraagt en dat ook de ziekenhuisarts niet moet vergeten, dat het minstens even belangrijk is te weten wat voor iemand een bepaalde ziekte heeft als wat voor ziekte een bepaald iemand heeft". Het realiseren hiervan is geen gemakkelijke zaak. Wanneer als voorbeeld genomen wordt de te uitgebreide zorgketen: Patiënt - huisarts - specialist en polikliniek - ziekenhuisopname (met tal van partiële zorgverleners) - verpleeghuis, dan ligt tussen de uiteindelijke zorgverleners, de ziekenverzorgsters en de fysiotherapeut van het verpleeghuis, een hele keten van personen en instanties. Inderdaad was deze keten in de achter ons liggende eeuwen korter. Dan belandde iemand die invalide was en chronisch verpleegd moest worden snel in een Godshuis of gasthuis. Maar dank zij de professionalisering, waarvan een der doelkenmerken is deskundigheid, bij voorkeur gebaseerd op wetenschappelijke kennis, wordt b.v. een bejaarde met een mediale collumfractuur (eeuwen geleden een invalide) nu een verpleeghuis bespaard. Een geamputeerde in de middeleeuwen moest noodgedwongen terugvallen op wat thans Hattinga-Verschure (1977) betitelt als „Mantelzorg" (familie-vrienden-buren). Het gevolg was wel dat de patiënt geen beroep kon doen op de prothesemaker, want voorzover men daarvan toen reeds kon spreken, werkte deze veelal voor de veldheer in wiens dienst hij was.

De prothesemaker was een gevolg van een beginnende professionalisering in het barbiersgilde, waaruit de chirurgijn is voortgekomen en later de chirurg. Deprofessionalisering, zoals deze wel eens bepleit wordt, biedt geen oplossing.

De gezondheidszorg staat bloot aan veel kritiek. Nogmaals, de deskundigheid wordt bewaard als een monopolie van de professie. Hierdoor kon een situatie ontstaan, waarin men geen of te weinig aandacht had voor bepaalde maatschappelijke veranderingen.

Een opvatting uit de na-oorlogse jaren. Doordat aan de geamputeerde op bepaalde leeftijd geen prothese verstrekt werd en hem juist op grond van die leeftijd zelfs geen gelegenheid geboden werd een poging te wagen weer ambulant te worden, belandde deze in het verpleeghuis. De nog vitale huwelijkspartner mocht niet mede opgenomen worden. Het bejaardenhuis had vaak niet voldoende mankracht, deskundigheid of ervaring om een geamputeerde te verzorgen. 
De eventuele kinderen waren door woningnood of de ten gevolge van die woningnood kleinere behuizing niet in staat hun ouders op te nemen. De problemen die zo ontstonden tussen huwelijkspartners, tussen ouders en kinderen, tussen verpleeg- en bejaardenhuis hadden niet de belangstelling van de operateur. De operateur, die dank zij successen in de vaatchirurgie of door betere inzichten in het behandelen van diabetes (er staat met opzet niet diabetespatiënten), mede bijdroeg tot bovengeschetste problematiek. De turbulente maatschappelijke ontwikkeling na 1945 deed veel nieuwe probleemgroepen ontstaan, welke niet terecht konden bij de bestaande hulpverleningsstructuren. De roep om meer samenwerking tussen de verschillende professies is dan ook zeer terecht en geldt in het bijzonder voor de gezondheidszorg, die geen gelijke tred hield met deze ontwikkeling.

Wil op het terrein van de revalidatie van patienten met beenamputaties een betere zorg tot stand komen voor geamputeerden, dan houdt voor- en nazorg in integratie met andere werkers in de gezondheidszorg. Naast het leren kennen en motiveren van elkaar houdt dit in een ter discussie stellen van zichzelf. Zijn nek niet uitsteken kan leiden tot een verdediging van de status quo, o. a. omdat men mogelijk bang is zijn identiteit te verliezen.

Bij de begeleiding van een geamputeerde na ontslag uit het revalidatiecentrum kan in principe iedere discipline betrokken raken, waarmee de prothesedrager tijdens zijn verblijf aldaar geconfronteerd werd.

Sinds 1973 bestaat in het R.C.H. het zogenaamde prothesespreekuur. Eénmaal per week biedt dit elke prothesedrager de mogelijkheid na oproep dan wel op eigen initiatief het revalidatie-centrum te bezoeken. Hij kan dan zijn moeilijkheden of wensen voorleggen aan de prothesioloog. Deze kan dan als coördinator van een amputatieteam al of niet verwijzen naar één van de deskundigen, welke op een eerder tijdstip uitgebreid op de hoogte was van de bestalande problemen. Dit leek ons echter niet voldoende. Uit ervaringen van anderen, werkzaam op prothesiologisch terrein, bleek dat maar al te vaak de prothese, korter of langer tijd na ontslag, op de rommelzolder terecht kwam. Op het prothesespreekuur werd deze alleen maar demonstratief getoond en gedragen. Uit eigen ervaring is bekend dat ook voor geamputeerden de arts vaak nog huist in de bekende , ivoren toren". Hun problemen bespreken zij liever met in hun ogen mindere grootheden. Of de arts zich hierdoor al of niet gefrustreerd voelt is onbelangrijk. Belangrijk is dat de patiënt, bij het omzeilen van de prothesioloog als coördinator van het amputatieteam, zichzelf tekort doet. Er dient een achterban te zijn in het eerste echelon, welke de prothesioloog kan attenderen op bestaande moeilijkheden.

Andere gehandicapten, men denke hierbij aan personen met diabetes mellitus of met een anus praeter naturalis, kunnen beschikken over adviezen van - of deelnemen aan activiteiten van respectievelijk de diabetes vereniging en de vereniging voor stomapatiënten. Waar het aantal beengeamputeerden snel stijgende is (n.l. met ruim 50\% van 1969 tot 1977), is het creëren van nazorg een zinvolle en urgent wordende zaak.

Een achterban, gevormd door de huisartsen, was een niet haalbare zaak. De huisarts is niet voldoende op de hoogte van de problemen, waarmee een geamputeerde geconfronteerd kan worden. Nascholing in deze bleek op praktische gronden onmogelijk. Dit gemis aan kennis is de huisarts overigens 
niet kwalijk te nemen, waar bepaalde specialisten de zorg voor geamputeerden wel clamen op grond wan hun opleiding, maar, op een enkele uitzondering na, eveneens leek zijn op prothesiologisch terrein.

Deze achterban voor prothesioloog en amputatieteam wordt gevormd door alle wijkverplegenden van Limburg. Ook met deze 350 wijkzusters bestaat sinds 1973 een jaarlijks contact tijdens de zogenaamde wintercyclus: een reeks van 5 avonden, waarop alle mogelijke informatie omtrent protheseproblematiek gegeven wordt. Het initiatief tot het mobiliseren van deze achterban in 1973 was een juiste keuze, gezien het enthousiasme waarmee de wijkverplegenden jaarlijks weer opnietw acte de presence geven en hun inzet voor de oud-revalidanten tonen. Uit deze contacten is verder voortgekomen het zogenaamde nazorgformulier. Door middel hiervan geeft de hoofdzuster van de afdeling, bij ontslag van de prothesedrager, aan de districtswijkverplegende relevante gegevens omtrent de patiënt door. De plaatselijke wijkzuster ontvangt rechtstreeks deze informatie, vooropgesteld dat zij bij het ontslag van de revalidant meteen ingeschakeld wordt. Dit alles overigens met medeweten en toestemming van de prothesedrager. In voorkomende gevallen maakt de plaatselijke wijkzuster, nog vór ontslag, in Hoensbroeck kennis met de prothesedrager.

Wintercyclus en nazorgformulier hebben tot gevolg gehad dat de arts regelmatig, voordat de geamputeerde het prothesespreekuur bezoekt, informatie ontvangt van de wijkzuster om tot een betere begeleiding te komen.

Mertens (1973) stelt ten aanzien van samenwerking in de nazorg: ,De weerstand tegen de opkomst van deze diensten wordt verwoord in de te verwachten moeilijkheden inzake beroepsgeheim, extra werk en: hoe meer communicatielijnen hoe meer kans op communicatiestoomissen, terwijl zeker ook onvoldoende kennis van, en daardoor veelal onvoldoende waardering voor elkaars werk van ziekenhuis en maatschappelijke gezondheidszorg in het geding is. Deze weerstand lijkt overigens te slinken. Omtrent het huidige peil ervan bij specialisten en hoofdverpleegkundigen in ziekenhuizen zijn mij geen gegevens bekend. Wat de huisarts betreft blijkt uit een onderzoek in 1971 van de Provinciale Raad voor de Volksgezondheid in NoordHolland dat in deze problemen $79 \%$ van hen geen bezwaar heeft tegen het rechtstreeks doorgeven van verpleegkundige informatie, $21 \%$ wel. Van de wijkverpleegkundigen in deze provincie zegt $83 \%$ behoefte te hebben an een georganiseerde nazorgdienst. $9 \%$ heeft deze behoefte niet. Tenslotte, het hoeft geen betoog dat met een netwerk van goed functionerende nazorgdiensten - en meer nog naarmate ook de communicatie specialist-huisarts verbeterd wordt - niet alleen de betrokken patiënten gediend zijn, maar ook de financiering van de gezondheidszorg; een en ander omdat ziekenhuisopnemingen bekort kunnen worden en (her)opnemingen voorkomen".

De 350 wijkzusters en het revalidatie-centrum heb ik wel eens vergeleken met een spinneweb, gesponnen over Limburg, waarin het R.C.H. centraal de plaats van de spin inneemt en gewaarschuwd wordt door de in dit web verspreide vliegjes. Het moge ten aanzien van de wijkzusters geen charmante vergelijking zijn, maar een spin is nog altijd zeer geïteresseerd in de vliegjes van zijn web, wanneer, gevoed worden" ter discussie staat. Als hommage 
aan deze Limburgse wijkverplegenden zou $\mathrm{k}$ willen zeggen:

Amputatie, Revalidatie en Evaluatie:

Ave Charysma en Caritas!

Voor- en nazorg, d.w.z. intensieve contacten met het tweede- en met het basisechelon zijn een conditio sine qua non, wil de behandeling van-en de zorg voor geamputeerden een ander karakter krijgen, dat tot betere resultaten leidt dan in het verleden mogelijk was. 


\section{Mens - Machine - Milieusysteem}

"Jede Person, die den Verlust einer Extremität oder ein Teiles davon erleidet, erfährt nicht nur physische. sondern auch bedeutsame psychische Anderungen, die von vielschichtigen Formen der Ablehnung der veränderten Körperlichkeit und der Auflehnung bis zu ebenso mannigfaltigen Formen des Akzeptierens - Z.B. der fatalistischen oder der aktiven realitätsbezogene Annahme-reichen." (Marquardt 1976)

De revalidatie van een geamputeerde is te vergelijken met het ontwikkelen en het goed laten functioneren van een mens-machinesysteem. De mens, de patiënt, de revalidant moet deskundig begeleid en behandeld worden door respectievelijk psycholoog, chirurg en revalidatie-arts. De machine - de prothese - moet, toegespitst op deze individuele mens, geleverd worden vanuit de samenwerking tussen prothesemaker en prothesioloog. Of deze combinatie, mens-machinekoppeling lukt, moet blijken uit de resultaten behaald door de patiënt, met behulp van verpleging, fysiotherapie, ergotherapie en maatschappelijk werk. Dit schema is een simplificatie van een soms complex geheel van factoren dat negatief dan wel positief bekrachtigend op het mens-machinesysteem kan werken. Het uiteindelijk resultaat is afhankelijk van de inspanning van elk der teamleden, die vanuit hun eigen discipline het probleem mens-machine benaderen. Dit vooronderstelt naast deskundigheid, de bereidheid tot samenwerking, het kunnen betreden van elkaars terrein, daar watar overlappingen bestaan, zonder dat dit als een inbreuk op eigen deskundigheid wordt gezien.

Naast de ziektegeschiedenis, die essentieel anders is bij de abrupte traumatische amputatie uit volle gezondheid, vergeleken bijvoorbeeld met een amputatie waaraan een langdurig vasculair Hijden ten grondslag ligt, spelen de opstelling van een amputatieteam, het gedrag van naaste verwanten, vrienden, kennissen, etc. een rol in het tot stand komen van genoemde koppelling.

De geamputeerde die aan zichzelf wordt overgelaten toont een ander gedrag dan de patiënt, die zich geborgen weet bij een deskundig team, dat hem op weet te vangen, o.a. ten aanzien van zijn angst voor toekomstig functioneren. Toekomstig functioneren, niet alleen met de prothese an sich, maar ook ten aanzien van zijn functioneren in de groep, van waaruit hij plotseling werd weggerukt en waarnaar hij wil terugkeren. Hoewel de prothesetechnieken in de jaren na de Tweede Wereldoorlog grote veranderingen 
hebben ondergaan - (men denke hierbij aan het toepassen van gietharstechnieken, het gebruik maken van de researchresultaten uit de ruimtevaart, de resultaten van biomechanisch onderzoek etc.) - lijkt de psychosociale problematiek waarmee een geamputeerde zich geconfronteerd weet geen vorderingen te hebben gemaakt.

De multidisciplinaire samenstelling van een amputatieteam moet deze achterstand met betrekking tot de psychosociale problemen opvangen en integraal verwerken, wil er sprake zijn van een alle aspecten omvattende optimale revalidatie. De arts-prothesioloog, die zich nog steeds waant in de ivoren toren, lokt daarmee een andere interdisciplinaire communicatie uit dan de arts die optreedt als de coördinator van het team. Coördinator naast zijn eigen deskundigheid en niet meer dan dat. Bewust of onbewust begrepen dit ook de patiënten die hun vertrouwen gaven aan dat lid van het amputatieteam dat in hun ogen dat vertrouwen waard was. Bewust of onbewust werd door de teamleden steeds getracht nimmer een situatie te scheppen zoals Gerendas (1973) deze beschrijft: ,A situation in which one person, the amputee, faces a group of individuals who are more or less strangers, who talk about him, frequently as if he were not there, and use technical terms he does not understand."

Uitgangspunt voor het amputatieteam was steeds dat het erkennen van een handicap door de patiënt iets geheel anders is dan het beleven ervan en er mee leren leven.

,,Being regarded as a person and not just as an appendix to a stump, considerations as to his worth as a human being, the requirement of privacy, a total person - "Gestalt" - approach versus disability, focused rehabillitation, are some of the other issues here." (Gerendas 1973)

Bovendien is het beleven van een handicap, o.a. in de competitie met andere gehandicapten, gecentraliseerd in een revalidatiecentrum, volslagen anders en niet vergelijkbaar met het beleven en doorleven van de handicap in de thuis- of werksituatie.

Marquardt (1976) komt tot de volgende conclusie: ,Wir glauben aber, aus unserer Untersuchung noch deutlicher als bisher die Forderung abzuleiten, das die Rehabilitation des Amputierten nicht dem Zufall überlassen bleiben darf, sondern das sie der interdisciplinaire Organisation bedarf."

"Interdisciplinaire Organisation", dat wil zeggen geen te hooi en te gras samengesteld team, maar een vast team voor een aantal in een revalidatiecentrum opgenomen patiënten.

Dat elke geamputeerde klinisch gerevalideerd zou moeten worden, is een uitgangspunt en regel waarop natuurlijk uitzonderingen mogelijk zouden moeten zijn. Bij een jonge man, een jonge vrouw, een kind met een traumatische amputatie lijkt op het eerste gezicht poliklinische revalidatie mogelijk te moeten zijn. Toch zijn er dan diverse problemen, die de afgelopen jaren ertoe bijdroegen dat poliklinische revalidatie zelden plaatsvond. Afgezien van het feit dat Nederland pas recent dagbehandeling kent, werden geamputeerden en amputatieteam geconfronteerd met factoren die altijd deden besluiten tot klinische revalidatie. De huisvesting van de geamputeerde kan problemen geven bij aanwezigheid van veel niveauverschillen of bijvoorbeeld afwezigheid van een lift in een flatgebouw. Naast de amputatie kunnen, 
als gevolg van het trauma, andere letsels bestaan, zoals een plexuslaesie van de arm, of een fractuur of pseudarthrosis van het andere been. Als voorbeelden van complicerende factoren bij de beslissing klinische of dagrevalidatie volgen hier een aantal casus uit de dagelijkse revalidatiepraktijk. Wat moet prevaleren bij een jongeman, bij wie de amputatie een gevolg is van de moeilijk instelbare diabetes? Een diabetes, welke bij overgang van het ziekenhuis naar het revalidatieprogram aanleiding gaf tot regelmatig optreden van hypoglycaemiën. Een andere jonge diabetiker, die, ondanks zijn nog jonge leeftijd, al een been had moeten missen, aangezien hij, alleen wonend en met een wat vreemde karakterstructuur, de zin van insulinemedicatie niet wilde of kon inzien en dieetvoorschriften niet wilde of kon opvolgen. Een scholier, wonend op $8 \mathrm{~km}$ afstand van de middelbare school, zonder mogelijkheid van vervoer anders dan het openbare, welke in "Hoensbroeck" naast prothesevoorziening en looptraining wel de gelegenheid kreeg zo min mogelijk achter te raken door begeleiding op de ,VIA". Een jonge vrouw, die zich thuis agressief gedraagt, omdat zij haar handicap nog totaal niet heeft kunnen accepteren en door haar vrienden en vriendinnen wordt gemeden. Een schippersdochter, een tiener, die een been moet missen, omdat zij letterlijk tussen wal en schip geraakte. De al of niet terechte schuldgevoelens van de ouders hadden hier een averechts effect, welke tot klinische revalidatie deed besluiten.

De tijd is nog niet lang voorbij dat men de problemen na een amputatie alleen maar zag als een prothesetechnische zaak.

Waar dit toe kan leiden mogen de volgende voorbeelden illustreren:

A. Een meisje van 20 jaar liep in 1968 bij een ongeval een tibiaplateaufractuur links op. Ten gevolge van een thrombus in de arteria poplitea moest een week na het ongeval een onderbeenamputatie links verricht worden. Prothesevoorziening vond plaats, waarbij alleen de prothesemaker geconsulteerd werd. Er werd een P.T.B. "-prothese verstrekt en de revalidatie van de patiènte verliep zonder problemen. Nauwelijks was te zien dat zij een prothese droeg. In december 1975 werd zij woor de eerste maal gezien op het prothesespreekuur in het revalidatiecentrum met enkele kleine pasvormproblemen van de prothesekoker. Nad at dit euvel verholpen was bleef zij onder controle van het R.C.H. Enkele maanden later ging zij klagen over een moe en pijnlijk gevoel in de linker knie. De röntgenfoto liet, als gevolg van de doorgemaakte tibiaplateaufractuur, een varusstand zien in het kniegewricht met een reeds duidelijke arthrosis deformans. De ziektegeschiedenis van 1968 vermeldde dat toen reeds een lichte zijdelingse instabiliteit bestond. Deze was toegenomen, terwijl ook de voor-achterwartse stabiliteit te wensen overliet. Het ligt voor de hand dat deze in 1968 ontstane instabiliteit in negatieve zin beinvloed was door thet dragen van een P.T.B.-prothese. Deze jonge vrouw, intusser getrouwd, wilde graag haar kinderwens vervuld zien. Zij woonde in een flatgebouw zonder lift. Wat betreft de huisvesting werd geadviseerd te verhuizen naar een flat met liftaccommodatie of naar een woning , met alles gelijkuloers". Hatar verlangen natu een kind was reden te meer om te gaan denken aan een conventionele prothese met leren dijbeenkoker wom het arthrotische kniegewricht te sparen. Van een operatieve standscorrectie was geen heil te verwachten. Zij was als 26-jarige te jong en te actief on het implanteren van een knie-endoprothese te overwegen. Deze jonge vrouw, die bij vorige poliklinische bezoeken zelfs een suprapatellair bandje om cosmetische redenen afwees, zag toch wel in dat er urgumenten genoeg waren om een conventionele prothese te gaan gebruiken. De fraaier ogende P.T.B.-prothese zou zij dan reserven als „uitgaansprothese". De acceptatie van de conventionele prothese, met zijn robuste lederen dijbeenkoker heeft zeer veel moeite gekost, mar was voorwaarde om het voldragen van een zwangerschap mogelijk te maken zonder een grote alanslag te doen op bet arthrotische kniegewricht. Nu, op 30-jarige leeftijd. heeft zij afgezien van deze kinderwens, mede omdat zij de uitbreiding van haar vroegere 
prothese niet kan accepteren. Deze vrouw had, gezien de knie-afwijkingen ontstaan in 1968 . destijds al gemotiveerd moeten worden tot het dragen van een conventionele prothese. Dan was mogelijk hel arthrotische proces langzamer verlopen en waren haar, jaren later, heel wat persoonlijke en huwelijksproblemen bespatard gebleven.

* P.T.B.: Patella Tendon Bearing.

B. In maart 1974 werd een man, geboren in 1897 , opgenomen. Sinds een tiental jaren had hij] progressieve claudicatioklachten en sinds 3 jaar werd diabetes mellitus geconstateerd. Drie weken voor de opname in her revalidatie-centrum was een onderbeenamputatie verricht met myoplastiek en myodese en, aarasluitend aan de operatie, een immediate fitting. Hij was, gezien zijn cardiale toestand, in het ziekenhuis nog niet gemobiliseerd. In december 1973 had hij een hartinfarct doorgemaakt. Desgevraagd gaf de man aan dat hij geen angineuze klachten had. Hij was weduwnatar en woonde samen met zijn zoon. Tweemaal per week was hulp aanwezig: overigens deed de man het huishoudinkje nog zelf. Bij onderzoek bedroeg de tensie $130 / 90$ $\mathrm{mm} / \mathrm{Hg}$. De pols was irregulair. Het cor was bij percussie naar beide zijden vergroot, de longgrenzen stonden laag en bij auscultatie werden basaal crepiterende rhonchi gehoord. Het bewegingsapparaat liet, conform de leeftijd, niet te wensen over. Het onderbeen was geamputeerd op $14 \mathrm{~cm}$ van de mediale gewrichtsspleet der knie. De wond was goed genezen. De kracht van de stompmusculatuur was zeer redelijk. De knieflexie liep van $0^{\circ}$ tot $90^{\circ}$. Er was geen instabiliteit in het kniegewricht.

Urine- en bloedonderzoek toonden geen duidelijke pathologie. De bloedglucosewaarden waren gedurende dle opname hoog normaal.

Röntgen thorax: matig vergroot hart naar beide zijden. Wat versterkte vaattekening met kalkafzetting in de , aortaknop".

E.C.G.: ., Vrij talrijke multifocale ventriculaire extrasystolen en enkele supraventriculaire extrasystolen bij myocardtibrose op de bodem van coronaursclerose. Een oud anteroseptaal infarct is waarschijnlijk."

Er werd een cardiotelemetrisch onderzoek verricht. De man liep hierbij met zijn gipsprothese enkele malen heen en weer in de loopbrug. De conclusie luidde: "De in rust al gesignaleerde vrij talrijke ventriculaire extrasystolen en supraventriculaire extrasystolen worden bij het lopen nog talrijker. Bij dit slecht myocard blijven de extrasystolen komen, ondanks de cardiale medicatie. Het is volkomen duidelijk dat lopen, hoe dan ook, veel riskanter is dan een leven vanuit de rolstoel. De patiënt wil echter lopen, côute que côte, en wel met een prothese."

Gewapend met deze zeer duidelijke stellingname van de functie-arts werden deze complicaties met de patiënt besproken. Ondanks onze uiteenzetting, die niets aan duidelijkheid te wensen overliet (, Magere Hein loopt met U mee") bleef de man bij zijn besluit dat hij, alleen lopend met een prothese het revalidatiecentrum wilde verlaten.

Begonnen werd met een zeer gelleidelijk opvoeren wan de conditie. Het is inderdaad gelukt zonder subjectieve klachten van de patiënt hem te leren lopen met een conventionele prothese en twee elleboogkrukken. Hiermee kan hij maximaal 150 meter afleggen, waarna hij toch wel enkele minuten behoefte heeft aan rust zonder dat er owerigens claudicatioklachten atan het andere been optreden. Diwerse malen werd voorgesteld om voor de man een rolstoel aan te schaffen. Dit werd echter met dezelfde halsstarrigheid afgewezen als waarmee hij destijds het advies tot definitief rolstoellewen van de hand wees. Nu, in 1978, 4 jaar later, verschijnt hij op het prothesespreekuur, lopend met 2 krukken. Hij is wolkomen tevreden. Grijnzend groet hij en zegt: , Ik ben ....." en wijzend in de lege ruatnte naast hem: , En daar staat Magere Hein."

Twee voorbeelden, mogelijk extremen van prothesevoorziening en revalidatie. Tussen deze twee uitersten bevindt zich echter het hele scala van patiënten met hun moeilijkheden en mogelijkheden.

Het mens-machinesysteem moet teruggeplaatst worden in het mensmillieusysteem, dat al of niet rekening houdt met de machinefactor. Het systeem mens-milieu is in voortdurende interactie. Binnen bepaalde grenzen kan de mens zich handhaven en functioneren in zijn milieu. Het systeem mens-milieu bereikt echter een kritische grens, wanneer bepaalde fysiolo- 
gische grenzen worden overschreden. Deze grens wordt overschreden door een verregaande mutilatie, waartoe een amputatie van een extremiteit zeker gerekend moet worden. Door een amputatie zien we dat het somatische, psychische en sociale functioneren op elke leeftijd verstoord wordt. De harmonie herstellen in dit mens-machine-milieusysteem is de taak van een amputaticteam.

Dit mens-machine-milieusysteem kan men differentiëren naar drie categorieën, elk met hun eigen specifieke problemen: bejaarden, volwassenen, kinderen en adolescenten.

\section{IV.1. De problemen rond de bejaarde mens}

De conclusies welke uit deze studie zullen volgen (zie hoofdstuk V en VIII) hebben voornamelijk betrekking op de bejaarde, die een beenamputatie heeft ondergaan. De problematiek rond een beengeamputeerde richt zich in de literatuur meer en meer op de bejaarde, waar decennia geleden het trauma (door industrie, verkeer en oorlogsgeweld) op de voorgrond stond.

,,Sinds de eeuwwisseling is het percentage 65-jarigen en ouderen bijna verdubbeld" (Sipsma 1977). Eveneens is hierdoor toegenomen de kans op een beenamputatie ten gevolge van een degeneratieve aandoening. Daar tegenover staat een relatieve daling van de beenamputaties ten gevolge van letsel opgelopen tijdens arbeid, door deelname aan het verkeer of door oorlogsgeweld. Het ligt dan ook voor de hand na te gaan welke veranderingen in de bevolkingsopbouw zich hebben voorgedaan en zich eventueel nog zullen voordoen, waardoor nu en in de toekomst meer rekening zal moeten worden gehouden met een verschuiving van amputatieproblematiek naar de mens op oudere leeftijd.

,,Sedert de Tweede Wereldoorlog hebben een aantal uiteenlopende ontwikkelingen hun invloed doen gelden op de omvang en samenstelling van de Nederlandse bevolking. Het aantal geboorten is, na zich aanvankelijk op een betrekkelijk hoog niveau gehandhaafd te hebben, zeker in vergelijking tot de ons omringende landen, vooral na 1965 sterk teruggelopen. De sterfte bij mannen en vrouwen heeft een uiteenlopende trend getoond. Bij mannen is, na een aanvankelijke daling een stijging opgetreden, vooral tussen 1960 en 1970 en bij de leeftijdsgroepen tussen 45 en 70 jaar. De laatste jaren is evenwel een zekere stabiliteit ingetreden. Bij de vrouwen is er nog steeds een voortgaande daling van de sterftekansen, al treedt ook hier een vertraging op. De migratie tenslotte liet in de jaren tot 1960 meestal een vertrekoverschot zien, doch na 1960 hadden de vestigingen de overhand. Het ligt voor de hand dat door al deze factoren niet slechts de totale omvang van de bevolking is gewijzigd maar dat ook de samenstelling naar geslacht en leeftijd belangrijke veranderingen heeft ondergaan. Aangezien de huidige situatie slechts een momentopname is, is evenzeer, of misschien nog meer, de vraag van belang hoe de toekomst zich zal ontwikkelen." (Van Oosterwijk-Bruyn 1977)

Op grond van de volkstelling op 31 mei 1947, de samenstelling der bevolking op 1 januari 1976 en een vooruitberekening voor 1 januari 2000 werden door Van Oosterwijk-Bruyn bepaalde voorzichtige conclusies getrokken. De 
door haar vermelde cijfers voor het jaar 2000 hebben betrekking op het gemiddelde van 2 alternatieve wooruitberekeningen door het C.B.S. in 1976 . Tussen 1947 en 1976 blijkt de totale bevolking met $1,25 \%$ per jaar te zijn toegenomen. Voor de periode tussen 1976 en 2000 wordt nog slechts een gemiddelde groei verwacht van $0,30 \%$ of ruim 40.000 personen per jaar. Gesteld wordt dat deze totaalcijfers echter een zeer onvolledig beeld geven van de werkelijke ontwikkeling.

\begin{tabular}{|c|c|c|c|c|c|}
\hline $\begin{array}{l}\text { Leofints } \\
\text { gmop }\end{array}$ & $\begin{array}{l}\text { Siand } \\
\text { 3f noted } 1947\end{array}$ & $\begin{array}{l}\text { Thendares } \\
\text { P947-1975 }\end{array}$ & $\begin{array}{l}\text { Shond } \\
\text { I jannani 1976 }\end{array}$ & 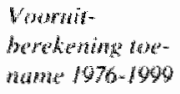 & 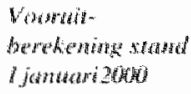 \\
\hline & $M$ & $M$ & $M$ & $H$ & $\mathrm{NH}$ \\
\hline
\end{tabular}

\begin{tabular}{|c|c|c|c|c|c|c|c|c|c|c|}
\hline & $\times 1000$ & & & & & & & & & \\
\hline (). 4 jeat & 598.8 & 567.6 & 87.0 & 78.9 & 511,8 & 488.7 & 6.3 .3 & 60.5 & 448,5 & 428,2 \\
\hline 5-19 jakr & 1258.5 & 1208.5 & 594,2 & 562,4 & 1852.7 & 1770.9 & 434.1 & 413.6 & 1418.6 & 1357.3 \\
\hline $20-39$ jatat & 1434.61 & 1465,2 & 695.4 & $\$ 26.8$ & 2129,4 & 1942,0 & 47.2 & 107.4 & 2176.6 & 2099.4 \\
\hline $40-64$ jaatl & 1174,2 & 1235.5 & 538.3 & 549.9 & 1712.5 & 1785.4 & 754.7 & 621.1 & 2467.2 & 2406.5 \\
\hline $65-79$ javir & 290.2 & 314.2 & 235,1 & 382.4 & 525.3 & 696,6 & 136,5 & 181.0 & 661.8 & 877,6 \\
\hline $80+$ & 35.7 & 43.1 & 69.5 & 120,0 & 105,2 & 163.1 & 29.3 & 112.7 & $13.4,5$ & 275.8 \\
\hline Totad & 4791.4 & 4874,1 & 2045.5 & 2062,6 & 6836,9 & 6896.7 & 470,3 & 548.1 & 7307.2 & 7444.8 \\
\hline
\end{tabular}

Bron: CBS.

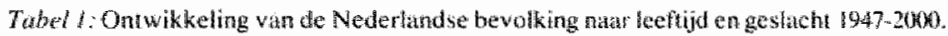

Tabel 1 splitst de bevolking in 1947, 1976 en 2000 naar gesiacht en naar aantal relevante leeftijdsgroepen. Vooral de grote verschillen bij de leeftijd boven 40 jaar komen duidelijk naar voren.

Tabel 2 laat de percentages zien voor diverse leeftijdsgroepen. Ook hier weer een beduidende toename voor de groepen boven de leeftijd van 40 jaar.

Van Oosterwijk-Bruyn (1977): , De leeftijdsgroep van 40-64 jarigen, die tot 1976 naar verhouding goed op peil gebleven is, zal in de komende 25 jaar een sterke toename te zien geven, bij de mannen nog aanzienlijk groter dan bij de vrouwen. In het jaar $2000 \mathrm{zal}$ dit dan ook de grootste leeftijdsgroep zijn geworden die, voor beide geslachten te zamen, ongeveer een derde van de bevolking omvat. 65-79 Jaar: de grootste relatieve toename heeft plaatsgevonden bij de oudste 2 leeftijdsgroepen. Tussen 1947 en 1976 nam het aantal mannen in deze leeftijdsgroep toe met ruim $80 \%$ en het aantal vrouwen zelfs met ruim $120 \%$. In 1947 waren er op elke 1000 mannen 1083 vrouwen. Tot het jaar 2000 wordt een verdere toename, bij beide geslachten, verwacht van ongeveer $26 \%$. Deze groep zal dan, beide geslachten te zamen gerekend, meer dan $10 \%$ van de bevolking uitmaken. 80 Jarigen en ouder: in 1947 behoorden bijna 80.000 personen tot deze groep. In 1976 waren dit er reeds 270.000 . Verwacht wordt dat dit aantal in 2000 gestegen zal zijn tot ca. 410.000 , ruim $5 \times$ zoveel als 50 jaar tevoren. Sterk ligt hier de nadruk op het vrouwelijk geslacht: op elke man zullen er 2 vrouwen zijn". 


\begin{tabular}{|c|c|c|c|c|c|c|}
\hline \multirow[t]{2}{*}{$\begin{array}{l}\text { Leefoifdrgroep } \\
\text { graep }\end{array}$} & \multicolumn{2}{|c|}{31 wien 1947} & \multicolumn{2}{|c|}{ Jannati 1970} & \multicolumn{2}{|c|}{$\begin{array}{l}\text { Voursiberedoming } \\
\text { 1 jumariti } 2000\end{array}$} \\
\hline & $M$ & $V$ & $M$ & $v$ & $M$ & $V$ \\
\hline (j- jak & 6.2 & 5.9 & 3.7 & 3.5 & 3,0 & 2,9 \\
\hline 5. 19 juar & $\| 3$. & 12.5 & 13.5 & 12.9 & 9.6 & 9.2 \\
\hline $20-39$ jactr & 149 & 15.2 & 45,5 & 14,5 & 14.8 & 14,2 \\
\hline $40-64$ jaxkin & 12,2 & 12.8 & 12,5 & 13.0 & 16.7 & 16.3 \\
\hline $65-79$ jasur & 3,0 & 3.3 & 3.8 & 5.1 & 4.5 & 6,0 \\
\hline $8 \mathrm{OH}$ & 0,4 & 0.5 & 0.8 & 1.2 & 0.9 & 4,9 \\
\hline Totatial & 49.8 & 50.2 & 49.8 & 50,2 & 49.5 & 50.5 \\
\hline
\end{tabular}

Tabel 2: Relatieve omvang var verschillende leefijdsgroepen der Nederlatndse bevolking in 1947 , 1976 en 2000. Totale bevolking $=100$.
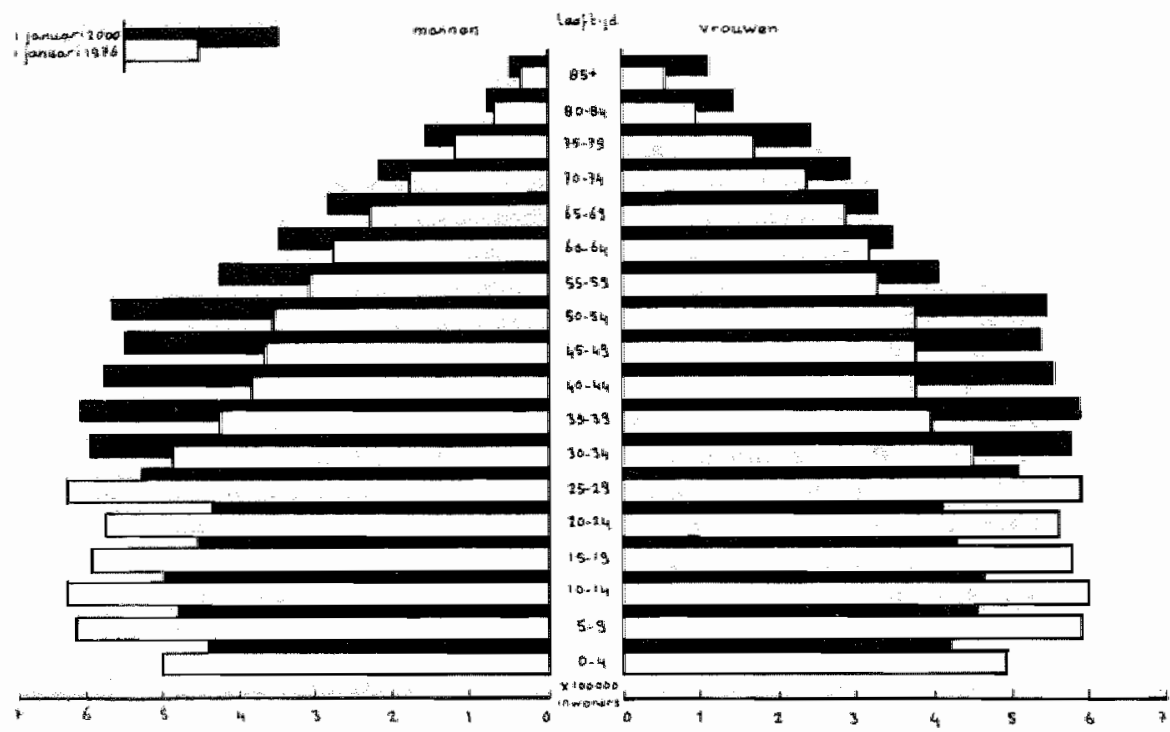

Fig. 8: Bevolking naar leeffijdsgroep en geslacht in 1976 en 2000.

Figuur 8 geeft een beeld van de veranderingen in de leeftijdsopbouw, waarin voor 1976 en 2000 voor mannen en vrouwen afzonderlijk de aantallen per 5-jarige leeftijdsgroep zijn weergegeven. Hieruit blijkt dat, ondanks een voortgaande groei van de totale bevolking, bij alle leeftijdsgroepen beneden de 30 jaar een teruggang optreedt, waartegenover een, deels zeer aanzienlijke toename staat voor de groepen boven deze leeftijdsgrens. Van OosterwijkBruy $n$ (1977) verwacht op grond van deze wijzigingen consequenties voor alle bovengenoemde groepen: ,De veranderingen in de aantallen 5-19 jarigen zullen in de eerste plaats consequenties hebben in de onderwijssector, terwijl een sterke toename van het aantal 40-64 jarigen het meest voelbaar zal zijn op de arbeidsmarkt". Boven de leeftijd van 64 jaar zal , een toenemend deel van de in ons land beschikbare middelen besteed moeten worden ten behoeve van de bejaarden. Ook het aantal personen dat direct of indirect ten behoeve van deze groep werkzaam zal zijn, zal sterk toenemen". 
Hoogendoorn (1977) merkt op: ,Het C.B.S. heeft in 1971-1972 een onderzoek ingesteld naar het aantal lichamelijk gehandicapten. Bij de in het onderzoek gebezigde classificatie van de ernst van de geregistreerde aandoeningen kan men de patiënten uit de categorie ,"4 en hoger" als zwaar gehandicapt beschouwen. Beperken wij ons tot deze laatsten, dan zou rond 1 januari 1972 ruim $3 \%$ van de bevolking van 5 jaar en ouder, of 380.000 personen tot deze ongellukkige groep behoren. Onder hen bevinden zich relatief veel bejaarden. Veroudering van de bevolking zal daardoor bij overigens gelijkblijvende omstandigheden het aantal gehandicapten doen toenemen. De berekeningen wijzen uit dat rond 1 januari 1972 het totale aantal zwaar gehandicapten omstreeks $32 \%$ hoger zou zijn geweest, indien de leeftijdsopbouw van de bevolking bij een gelijk aantal inwoners op dat tijdstip zou zịn overeengekomen met de samenstelling die per 1 januari 2000 wordt verwacht".

Met betrekking tot de verpleegkliniek stelt Hoogendoom (1977): ,,Een per 1 januari 1973 verrichte patiëntentelling (Geneeskundige Hoofdinspectie van de Volksgezondheid e.a. 1976) maakt duidelijk dat de bedden van onze verpleegklinieken voor een zeer groot deel worden bezet door bejaarden en hoog-bejaarden. Veroudering van de bevolking in de mate als verwacht tegen 1 januari 2000 zou, ceteris paribus, de behoefte aan deze bedden met niet minder dan $47 \%$ doen toenemen en bijna $50 \%$ van de bedden zou gebruikt worden voor de verpleging van de patiënt 79 (!) jaar en ouder".

Dat deze toekomstvisie te somber afgeschilderd zou zijn kan men niet weerleggen met het gegeven dat het ceteris paribus-beding in de praktijk wel niet op zal gaan. Immers, volksgezondheid en gezondheidszorg zijn geen statische begrippen. Methorst daarentegen, geciteerd door de Moor (1956), voorspelde al in 1948 dat het relatieve aandeel van de groep van 65 jaar en ouder in $197511,5 \%$ zou bedragen. Het C.B.S. berekende in 1976 voor bovengenoemde groep $10,9 \%$ (zie tabel 2).

De profetie van Methorst is niet ver bezijden de waarheid. Dat men de mogelijkheid van het ontstaan dezer bovengeschetste problemen onderkent en dat men tijdig vanuit de dienstverlening aan- en revalidatie van gehandicapten hiermede terdege rekening moet houden is evident.

In het revalidatie-centrum te Hoensbroeck werden tussen juni 1972-juni 1977125 patiënten opgenomen, aansluitend aan één of meer amputaties der onderste extremiteiten. $80 \%$ van deze geamputeerden was ouder dan 50 jaar. Bijna $1 / 3(31 \%)$ was ouder dan 70 jaar. Gezien dit gegeven en in het licht van de bovenvermelde toekomstvisie kan men dan 2 alternatieve beleidsuitgangspunten tegen elkaar afwegen:

A. Het bouwen van steeds meer bejaarden- of verpleeghuizen voor deze categorie van onze steeds meer vergrijzende bevolking. Een bevolking waarvan het productieve deel steeds kleiner wordt, terwijl de vooruitzichten op een kentering bij lange na nog niet in zicht zijn.

B. Men kan ook proberen de bejaarde geamputeerde toch zijn eigen levensstijl zo goed mogelijk te laten behouden met betrekking tot huisvesting, activiteiten en sociale contacten. Behalve een niet te verontachtzamen vermindering van de kosten voor onze gezondheidszorg, heeft dit alles te maken met een terechte claim van deze steeds groter wordende groep bejaarden hun levenswijze mede te mogen bepalen. 
Mensen worden niet ouder dan vroeger; meer mensen dan vroeger worden oud. Was vroeger een lang leven uitzondering, nu is dit steeds meer regel aan het worden. Het gevolg hiervan is dat steeds meer mensen geconfronteerd worden met de gevolgen van degeneratieve ziekten al of niet met de complicatie van een beenamputatie.

Ouder worden betekent niet alleen een achteruitgang van psychische en somatische kwaliteiten, maar ook een verandering in sociaal opzicht. Het functioneren in sociaal opzicht inclusief de status die men na pensionering krijgt, bestemt in belangrijke mate het al of niet optreden van frustaties bij het zoeken naar bevrediging van bepaalde wensen, waardoor ook het gedrag van de mens beïnvloed wordt. Jeugd en volwassenheid, zij vloeien ongemerkt in elkaar over. De oudere mens, de bejaarde heeft zijn taak in maatschappelijk opzicht vrijwel vervuld, is niet meer belangrijk woor het voortbestaan van het geslacht. De bejaarde die dit, gedwongen door de maatschappij, als zodanig ervaart voelt zich nutteloos. De maatschappij, of juister gezegd het samen leven kan het ouder worden meer unhoud geven. De maatschappij van mensen zal zich moeten bezinnen op het feit dat, waar men vroeger in staat was zich aan te passen aan een klein aantal bejaarden, nu een groot maatschappelijk probleem dreigt te ontstaan. Oorzaak van dit probleem is niet alleen de bovengeschetste wijziging van de bevolkingsopbouw. Ook grote veranderingen in maatschappelijke structuren, opgeroepen door de industrialisatie, zijn hier debet aan. Zowel in tijden van hoogconjunctuur, als in de huidige economische crisis wordt de ouder wordende mens als eerste uit het arbeidsproces verwijderd. Iemand met pensioen sturen is door de industrialisatie pas mogelijk geworden in de $20 \mathrm{e}$ eeuw. Dit tijdstip van, ,welverdiende rust" lijkt, dan wel dreigt, steeds lager te worden. Was productiviteit en welvaart enkele decennia geleden oorzaak van dit verschijnsel, tegenwoordig is het omgekeerde het geval. Het effect van deze processen voor de oudere mens komt op hetzelfde neer.

Met de industrialisatie hangt nauw samen de verstedelijking; zeker geldt dit voor Zuid-Limburg.

Geleen bestond rond de eeuwwisseling uit drie woonkernen: Lutterade, Krawinkel en wat nu oud Geleen wordt genoemd. Drie agrarische woongebieden, die door de staatsmijn, ,Maurits", het SBB en later DSM werden tot een complex geheel: een snelle metamorphose van agrarische gemeente tot industriestad, toen in 1923 de Maurits in exploitatie werd gebracht. Destijds namen dezelfde mensen aan bijna alle groepen deel, zodat er werkelijk sprake was van één geheel. ,De onderlinge relaties hadden betrekking op de gehele mens. Men zag in de ander de mens met zijn gehele achtergrond van een bepaalde familie, een bepaald beroep, van een bepaalde postitie in het dorp en een bepaald verleden. De normen en de gedragswijzen in de verschillende groepen vertoonden een homogeen karakter, terwijl het hele cultuurpatroon betrekkelijk statisch was. In zulk een samenleving zal de oude mens in het algemeen niet sociaal geisoleerd worden. Hij zal een bepaalde plaats blijven innemen en een bepaalde waardering blijven genieten. En ook, indien hij mocht ophouden met werken, zal dit zijn deelnemen aan het sociale leven niet in de weg staan". (De Moor 1956.)

Het Limburgs Dagblad van zaterdag 18 februari 1978 meldt op de voor- 
pagina: , Momenteel ligt 1 miljoen Nederlanders met griep in bed. Onder hen zijn enkele duizenden alleenstaainden en bejaarden, die hierdoor in een noodsituatie zijn gekomen. Veel van deze alleenstaanden en bejaarden zijn van burenhulp verstoken, weten niet waarheen en zijn radeloos". Deze noodkreet zou in de Limburger Koerier, 50 jaar geleden, niet nodig zijn geweest. Toen functioneerde nog optimaal de zogenaamde mantelzorg.

Industrialisatie en verstedelijking hebben mede de familiestructuur gewijzigd. Diverse generaties, grootouders, getrouwde en ongetrouwde kinderen alsmede de kleinkinderen woonden voorheen vaak bij elkaar. Via de familie werden de sociale contacten onderhouden. Andere kinderen woonden niet ver van dit stamgezin en bleven er hecht mee verbonden. De volwassen geworden kinderen en hun kinderen zorgden ervoor dat de bejaarde mens niet geïsoleerd raakte. Door industrialisatie, mobiliteit van de bevolking en de verstedelijking werd deze familiestructuur veranderd. Bejaarde mensen wonen nu meestal alleen en dreigen na pensionering hun sociale contacten te verliezen, welke contacten anders dan vroeger niet via de familie maar merendeels via het beroepsleven tot stand kwamen.

,Het percentage 65 jarigen en ouderen is sinds de eeuwwisseling bijna verdubbeld en in bepaalde gebieden in ons land zelfs ruim verdubbeld. "het varieert thans van $10 \%$ tot in sommige streken zelfs $14 \%$ van de totale bevolking". (Sipsma 1977.)

Hoe een bejaarde de laatste levensfase beleeft hangt direct samen met de opvoeding, opleiding, uitgeoefend beroep, al of niet gehuwd zijn, relaties met familie en milieu, kortom zijn gehele levensachtergrond bepaalt in welke richting zijn oude dag zich zal gaan bewegen. Somatische, psychische en sociale aspecten zijn hier ten nauwste met elkaar verweven. De bejaarde kan echter, evenals het kind en de volwassene, in deze levensfase mede richting geven aan zijn gedragspatroon. Dit patroon is geen onontkoombaar gegeven of strikt gebonden aan de voorbije levensgeschiedenis. Een wijs, verdwijnend gezegde vat dit samen: ,,In het verleden ligt het heden, in het nu wat worden zal".

In het mens-machine-milieusysteem, toegespitst op de bejaarde geamputeerde, is het belangrijk onze aandacht te richten op elk van de onderdelen van dit systeem. Te meer, omdat in de psychologische en sociologische literatuur veel aandacht besteed wordt aan dit systeem, zij het dat de machine - de prothese - daarin nog niet als complicerende factor aan de orde komt.

Van Proosdij (1977) geeft 5 adviezen welker behartiging in aanzienlijke mate het lichamelijk en geestelijk welzijn van bejaarden bevordert:

- Neem voldoende lichaamsbeweging.

- Onderhoud de nodige contacten met uw medemensen.

- Blijf geestelijk zoveel mogelijk actief.

- Zorg voor adequate voeding.

- Laat uw gezondheidstoestand periodiek controleren door uw huisarts.

Het merendeel van de bejaarden, die naderhand een amputatie ondergaan, lijden aan atherosclerose, al of niet gecombineerd met diabetes. De claudicatio intermittens vormt daarbij vaak nog een extra beperkende factor ten aanzien van loopafstand en loopsnelheid. Visusvermindering door diabetes, toenemende verkeersdrukte, het verdwijnen van de vertrouwde, ,winkel om 
de hoek", het steeds meer toenemen van de onpersoonlijke supermarkten met de voor deze bejatarde beangstigende roltrap, de lieve jeugd, die lak heeft aan etiquetteregels, etc., etc. maken het dan moeilijk voor de bejaarde het eerste advies van van Proosdjj op te volgen. De fluitende bakkers- en slagersjongens zijn verleden tijd. Het bejaarde echtpaar doet al gauw slechts $I x$ per week boodschappen. Dit staat niet veel variaties in het menu toe. Bekend is de . soep voor de hele week" evenals andere eenzijdige voeding van bejaarden. Het niet meer kunnen opvolgen van het eerste advies houdt in dat in het claudicatiostadium aan ..zorg voor adequate voeding" niet meer wordt voldaan, terwijl ", onderhoud de nodige contacten met uw medemens", alsmede "blijf geestelijk zoveel mogelijk actief" ook danig in het gedrang komen.

Elke arts weet uit ervaring dat veel bejaarden hun klachten niet snel uiten bij hun huisarts. ".Het is de leeftijd" en ..er is toch niets meer aan te doen" of de dreiging van een onderzoek in het ziekenhuis weerhouden de bejaarden waak het laatste advies op te volgen: "Laat uw gezondheidstoestand periodiek controleren door uw huisarts".

In 1977 werd bij 2000 bejaarden in de Gemeenten Beek en Swalmen een onderzoek verricht door de Rijksuniversiteit Limburg in samenwerking met het Matatschappelijk Medisch Centrum te Beek. Onder meer werd geconstateerd dat het percentage bejaarden dat hun gezondheidstoestand als ..goed" qualificeerde lager lag vergeleken met het percentage .,goed" dat verkregen werd na onderzoek naar deze lichamelijke gezondheidstoestand. Voorts was in beide Gemeenten het percentage bejaarden dat onder behandeling was van huisarts en/of specialist zo groot dat dit, gezien de relatief grote omvang van de medische zorg voor bejaarden, de belasting die bejaarden betekenen voor de (eerstelijns) gezondheidszorg duidelijk onderstreepte.

(Bejaardenonderzoek Beek-Swalmen 1977.)

Desondanks stelt van Proosdij terecht (1977) dat: .. Vooral de huisarts een sleutelpositie inneemt om te bevorderen, dat de op leeftijd komende personen uit zijn praktijk niet tot hulpbehoevende, zieke ouden van dagen worden".

De huisarts dient toe te zien op het volgen van deze adviezen. Noemt van Proosdij het rectumcarcinoom als berucht voorbeeld, waarvan de bejaarde de symptomen bagatelliseert dan wel meent dat dit ouderdomsverschijnselen zijn, een persoonlijke ervaring is dat bejaarden met claudicatioklachten vaak hieromtrent dezelfde mening koesteren.

Bovenstaand commentaar op adviezen van een internist-geriater met betrekking tot bejaarden met insufficiente circulatie van de onderste extremiteiten was bedoeld om aan te tonen hoe snel dan de conditie van deze bejaarde achteruitgaat vergeleken met het .,krasse oudje ". Dat tenslotte opname in het ziekenhuis. bedlegerigheid, het vaatonderzoek, de eventuele vasoreconstructieve ingreep en bij mislukken hiervan de amputatie deze conditie nog meer negatief zullen beïnvloeden hoeft verder geen betoog. Dit is dan de mens die voor revalidatie ten aanzien van het mens-machine-milieusysteem wordt aangeboden. Een ..machine" welke voor goede besturing, afhankelijk van het amputatieniveau. $20 \%$ of meer energie vereist dan vór de amputatie.

Zoals gesteld kan deze achteruitgang in lichamelijke conditie vaak beginnen lang voordat opname in het ziekenhuis volgt. Wanneer zijn actieradius 
door de pijn verminderd wordt en het leven van alledag nog meer beperkt is. kan psychische regressie daaraan inhaerent zijn. Als gevolg van de interactie tussen somatische klachten en psychische achteruitgang bestaat dan de kans op prae-dementie, waarvan het optreden nog versneld wordt doot opname in het ziekenhuis, weg uit de vertrouwde ongeving. Deze nieuwe, vreende omgeving kan bedreigend gaan werken en aanleiding geven tot een seniele decompensatie.

Ofschoon de bejaarde in het ziekenhuis met de meeste aandacht, gericht op zijn somatische verbetering wordt omringd. heeft deze zorg soms een averechts effect, vaak versterkt door de vaatoperatie of de neiging van de patiënt zich aan de onafwendbare amputatie te onttrekken. Dit proces bij bejaarden verschilt wezenlijk van dat bij de jonge patient, die plotseling geconfronteerd werd met de amputatie ten gevolge van een trauma. De jonge patiënt, waarvan het lichaam en de geest nog niet werden geconfronteerd met een vaatlijden in alle omvang, moet dan nog anticiperen op de harde confrontatie met de amputatie. Deze confrontatie met de amputatie heeft bij beide categoriën tot gevolg een aanslag op het existeren als mens, zij het op een ander vlak. De bejaarde, door zijn ervaring opgedaan in het ziekenhuis intuitief al lang min of meer vertrouwd met de mogelijkheid van een amputatie, is zich al of niet bewust van de lichamelijke achteruitgang. Hij heeft als voorland een periode waarin zijn lichamelijke conditie weer op een zodanig peil gebracht wordt, dat prothesevoorziening en looptraining mogelijk worden. Het moeten ervaren dat de geest wel gewillig, maar het vlees uiterst zwak geworden is, brengt nieuwe problemen met zich mee. Het amputatieteam hiermee bekend en vertrouwd te maken en in deze team en geamputeerde te begeleiden, is een taak van de psycholoog. Dat bij een traumatische amputatie bij een jonge patiënt het vlees wel gewillig is, maar de geest behoefte heeft aan steun ligt voor de hand, evenals de taak die de psycholoog in deze heeft.

Tracht de psycholoog op psychisch niveau een nieuw evenwicht te bereiken, de arts zal bij het zoeken naar een verbetering van de lichamelijke conditie er rekening mee moeten houden, dat het cardiorespiratoire systeem door de gevolgen van amputatie nog zwaarder belast gaat worden. Atherosclerose is een ziekte die veel systemen van het lichaam treft. Naast hart en longen krijgt het .,gezonde been" nu meer te verduren, terwijl belangrijke organen als lever en nieren door het atherosclerotische proces ook niet ongemoeid blijven. Medicamenteuze therapie, gericht op ondersteuning en verbetering van het hart-longsysteem vraagt dan bijzondere aandacht.

,Cardiale en pulmonale nevenwerkingen, die door een jongere patiënt zonder ernstige bezwaren worden verdragen, kunnen echter het leven en de psychische en somatische gezondheid van de bejaarde ernstig bedreigen" aldus Offerhaus (1977). , Het is dus van groot praktisch belang om bij ouden van dagen de indicatiestelling, dosis en het doseringsinterval van werkelijk nodige geneesmiddelen aan de individuele patiënt aan te passen, op geleide van de door diens leeftijd en lichaamssamenstelling aan te nemen of te meten fysiochemische verandering. Daarbij moet worden gestreefd naar een minimum aantal medicamenten, een juiste, liefst dringende indicatie, een dosering die niet meer is maar ook niet minder dan eenmaal daags, duidelijk liefst geschreven instructies en een regelmatige revisie van het geneesmiddelen- 
pakket. waarbij men niet moet terugschrikken voor een drastisch gebruik van het rode potlood". Uit het reeds genoemde onderzoek van de R.L. en het M.M.C. te Beek bleek dat de geneesmiddelen consumptie toeneemt bij stijgende leeftijd. De onderzoekers concludeerden: . Het percentage op zichzelf wettigt wellicht een poging het aantal/de soorten medikamenten bij alle bejaarden nog eens kritisch te bezien".

(Bejaardenonderzoek Beek-Swalmen 1977.)

Bijzonder belangrijk bij het verbeteren van de conditie is de begeleiding door de functie-arts van het R.C.H. Het is bekend hoe conditieverbetering vaak samengaat met verbetering van het lichamelijk en geestelijk welzijn en welbehagen. Bij de in het centrum verrichte conditiebepalingen, wordt het E.C.G. tijdens inspanning continu geregistreerd en beoordeeld. Vaak wordt ook de ademfrequentie geregistreerd en steeds worden de bloeddrukwaarden tijdens inspanning gemeten. Aan de fysiotherapeuten en aan de afdeling "Sport en Spel" wordt doorgegeven hoever men in cardiopulmonaal opzicht bij het oefenen en trainen kan gaan. Dit cardiotelemetrisch onderzoek wordt ook bij de geamputeerde bejaarde in variabele omstandigheden verricht. Dit onderzoek wordt tijdens de revalidatieperiode meerdere malen herhaald in loop- of zwembad, op gangen, op hellingen, in het trappenhuis of in het geaccidenteerde terrein van het park rond het centrum.

Wanneer zo de algehele conditie weer op een niveau gebracht is, dat prothesevoorziening en looptraining mogelijk worden, lijkt het goed onze aandacht te richten op het bewegingspatroon van de bejaarde mens. Het proces van verouderen is geen optelsom van een aantal ouderdomsgebreken. Ook de bejaarde, die aan vitaliteit niet lijkt te hebben ingeboet, is oud hetgeen zich uit in lichaamsbouw, gelaatstrekken, houding, motoriek en mimiek. De motoriek van de oude mens wordt gekenmerkt door bewegingsarmoede en het ontbreken van combinatie-bewegingen. Vergeleken met de ongedurigheid en dynamiek van kinderen en jonge mensen, lijkt de oude mens uitgeblust, tot rust te zijn gekomen. , Deze rust" zegt Buytendijk (1964) is ,.echter niet die van de slaap, maar een wakend, volwaardig levend rusten". Waar de bovengenoemde twee kenmerken het gevolg zijn van somatische veranderingen, in hoofdzaak gelokaliseerd in het extra-piramidale systeem, wordt het tot rust komen van de bejaarde mens bepaald door zijn veranderde verhouding tot de wereld. Dit wordt door Buytendijk geduid als distantiëring. .,Van deze positie der distantie en rust uit leeft de oude mens in-en-met-de-wereld', die thans voor hem een tafereel geworden is, een gebeuren, dat op zichzelf verloopt, een "comédie humaine', objectief aanschouwd en als in een theater op afstand meegeleefd ". De volgende citaten mogen deze karakteristieken van de ouderdomsmotoriek verduidelijken:

Schreuder (1968): .. De bejaarde kan moeilijk bewegingen combineren. Men kan dit zien als men op strat bejaarden waarneemt. Een oudere heer kan onder het lopen niet zijn handschoenen aantrekken; hij blijft daarbij stilstaan. De gezonde bejaarde kan moeilijk zijn bewegingspatroon wijzigen, men merkt dit als een bejaarde aan de overkant van de straat een kennis ziet; hij moet eerst stilstaan voor hij kan starten voor de nieuwe beweging van de straat oversteken. De start is bovendien moeilijker dan bij jongeren; de 
spieren zijn zeer gespannen: de patiënt maakt hierdoor op zeer hoge leeftijd een enigszins Parkinsonachtige indruk".

Van Proosdij (1977): ,Het moeilijk omschakelen van handelingen tenslotte wordt zichtbaar wanneer een bejaarde tot onze disgenoten behoort. Jonge mensen kunnen aan tafel een gesprek voeren zonder met volle mond te praten en ondertussen dooreten. Indien een bejaarde aan tafel moet converseren komt hij achterop met eten. Niet omdat hij zo langzaam kauwt of wordt gehinderd door een slecht gebit, ook niet, in eerste instantie, door tempoverlies. Indien dezelfde bejaarde alleen zit te eten en niet hoeft te praten is hij vaak verrassend gauw klaar. Allerlei complexe verrichtingen worden op gevorderde leeftijd onderdeel na onderdeel uitgevoerd 'in getrennte Einzelakten'. Simpel gesteld: een bejaarde kan maar een ding tegelijk doen. Alles kost daardoor meer tijd dan vroeger, ook al kan elke beweging afzonderlijk nog voldoende snel worden uitgevoerd".

Munnichs (1956): „De bejaarde is traag, langzaam, schakelt zich moeilijk om zowel in het denken als bij het concrete handelen. Hij blijft lang stilzitten en ziet toe. De lanen en parken in stad en dorp zijn 'agorai' voor de bejaarde; daar kan men ze altijd aantreffen. Opvallend is de toewending naar optische indrukken, naar het spel der kinderen, het passeren der wandelaars, naar een roep, geruis of gesprek, naar al wat er geschiedt uitsluitend door hoofd- en oogbewegingen. Buytendijk legt nadruk op dit laatste door te wijzen op de tegenstelling die er bestaat tussen de geringe activiteit en de levendige belangstelling en mimiek".

Dit veranderde loop- en bewegingspatroon van de bejaarde wordt mede veroorzaakt c.q. bedreigd door arthrosis deformans van heup, lendenwervelkolom en knie, cerebrovasculaire accedenten en atherosclerose van de beenvaten. Gezien dit veranderde bewegingspatroon van de bejaarde kan men zich voorstellen hoe moeizaam het revalidatieproces kan verlopen een bejaarde na amputatie van een extremiteit weer ambulant te maken.

Schreinemachers (1971) c.s. deden een na-onderzoek bij 67 patiënten, waarbij in de periode van januari 1960 tot juli 196883 bovenbeenamputaties werden verricht. Ten tijde van dit na-onderzoek waren 31 van de 67 patiënten overleden. De onderzoekers correlleerden het tijdstip van overlijden na amputatie met de leeftijd van de patiënt ten tijde van de amputatie. Uit deze gegevens blijkt dat een amputatie, verricht boven de leeftijdsgrens van 70 jaar, reeds een late letaliteit van $50 \%$ oplevert, terwijl zeer weinig patiënten in de leeftijdsgroep boven de 80 jaar een amputatie langer dan een half jaar bleken te overleven. De onderzoekers stellen: , In de leeftijd boven 70 jaar kan er immers in zeer veel gevallen geen sprake meer zijn van revalidatie. Deze mensen worden bedlegerig, met alle gevolgen van dien voor bepaalde patiënten. Zeer vaak zal er bovendien een gebrekkige verpleging thuis plaatsvinden, hetzij omdat de patiënt er de voorkeur aan geeft thuis te worden verpleegd, hetzij omdat er geen plaats is in een verpleegtehuis. Het lijkt ons daarom gewenst dat de verpleging van deze patiënten thuis beter begeleid wordt door de sociale diensten of door de kruisorganisaties. Ook verdient het aanbeveling deze groep van patiënten eerder voor eventuele reconstructieve vaatchirurgie in aanmerking te laten komen". Voorts concluderen Schreine- 
machers $c_{.}$s.: "Er is een hoge sterfte in de oudere leeftijdsgroep. Tijdige vaatchirurgische behandeling of betere opvang van de bejaarde patiënt na amputatie zou kunnen leiden tot een opmerkelijke verbetering van de prognose. Waar de taak voor de verbetering ligt, is niet nauwkeurig omschreven, maar het is zeker niet zo, dat de arts en speciaall de behandelend arts en de huisarts zich aan deze verplichtingen kunnen onttrekken".

Met betrekking tot de vaatchirurgie, welke bij bejaarden op een eerder tijdstip uitgevoerd had kunnen worden, waardoor hen een amputatie op bovenbeenniveau bespaard had kunnen blijven, is een mening niet terzake. Het overleg tussen vaatchirurg en huisarts kan hier wel verbetering in brengen. De selectie van bejaarden daarentegen in verband met een revalidatiemogelijkheid dient klinisch door het amputatieteam plaats te vinden en niet poliklinisch door de in consult geroepen revalidatie-arts alleen. Veel facetten dienen betrokken te worden bij de keuze tussen wel of geen revalidatiekans, of revalidatiemogelijkheid om deze tot een weloverwogen en goed gefundeerde keuze te maken. De bejaarde patiënt dient zodanig over deze keuze te worden geïnformeerd dat hij vrede kan hebben met het rolstoelleven, dat hem eventueel nog rest, thuis of in het verpleeghuis.

\section{2. De problemen rond de volwassene.}

Bekend is hoe na het 20 ste tot 25 ste levensjaar een biologisch verouderingsproces begint. Topsport wordt meestal onder deze leeftijdsgrens bedreven en levert, althans voor een aantal sporten, geen kampioenen meer op die deze grens overschreden hebben. In het leven van alledag merkt een persoon of zijn omgeving deze veroudering nauwelijks op, zeker niet tot bijvoorbeeld de leeftijdsgrens van 35 jaar. Daarna zijn er ervaringsfeiten, die de mens nog niet regelmatig met zijn veroudering confronteren. Een vader van 45 jaar die dan moet constateren dat hij het lichamelijk moet afleggen tegen zijn zoon van 15 jaar, zal vaak eerder een gevoel van trots ervaren omdat hij zijn zoon ziet opgroeien tot man.

Een vader van 25 jaar met een traumatische bovenbeenamputatie, die niet meer ravotten kan met zijn zoon van 3 jaar, ervaart iets geheel anders dan trots. Machteloosheid, het niet meer kunnen voldoen aande wensen van zijn ravottend zoontje, maakt hem hard attent op zijn geschonden lichaam.

In hoofdstuk II werd gesproken over de diverse fasen, welke zich globaal zouden voordoen op psychisch niveau wat betreft het rouwproces na een amputatie van een lidmat: de ontkenning, de agressie en depressie, de berusting en aanvaarding. Voor berusting en aanvaarding lijkt ook veel levenswijsheid noodzakelijk, levenswijsheid die niet gebonden is aan intelectuele capaciteiten, maar groeit met het klimmen der jaren.

De 25-jarige vader zal nog zeer vaak agressie en verdriet om voorrang voelen vechten, voor berusting en aanvaarding een competitieve rol krijgen toebedeeld. Een competitie die pas vele jaren later een evenwicht kan opleveren, waardoor de handicap niet meer elke dag storend wordt beleefd. Hoewel de diverse orgaansystemen op jongere leeftijd na amputatie niet sneller zullen verouderen, zal de geamputeerde mens het verouderingsproces wel sneller ervaren; hij kan immers niet meer voldoen aan bepaalde lichamelijke presta- 
ties op 25 jarige leeftijd, waartoe de 35 -jarige nog met gemak in staat is.

Wanneer Lehman (1953) een duidelijke relatie vindt tussen de leeftijd van personen enerzijds en de kwaliteit en kwantiteit van hun werk anderzijds, dan mag dit soms t.a.v. werken nog opgaan voor geamputeerden. Leven is echter meer dan werken alleen. Ofschoon biologisch gezien er geen snellere achteruitgang is, wanneer we de volwassen geamputeerde met een gezonde leeftijdsgenoot vergelijken, dan heeft het subjectieve ervaren van een geamputeerde ten aanzien van lichamelijke prestaties toch ook invloed op zijn persoonlijkheidsontwikkeling. Veel eerder dan de gezonde volwassene zal hij ervaren dat de dromen uit zijn jeugd niet bewaarheid zullen worden. De gezonde ouder wordende mens komt tot overeenstemming met zichzelf: hij erkent zijn eigen tekortkomingen, zijn eigen capaciteiten en begrenzingen. Hij gaat zichzelf accepteren zoals hij is.

Hiermee moet de 25 -jarige met een traumatische bovenbeenamputatie eerder rekening houden. Dat dit invloed zal hebben op zijn persoonlijkheidsontwikkeling is evident. Gelukkig de man, waarbij dan erfelijke factoren zoals genetische karakteristieken, temperament, etc. met daarnaast aangeleerde eigenschappen, bepaald door culturele achtergrond, levensgeschiedenis, opleiding en opvoeding het mogelijk maken te woekeren met de capaciteiten die hem resten. Deze capaciteiten zullen vaak de agressie en depressie, opgeroepen door de handicap, kunnen compenseren door onvermoede kwaliteiten verder te ontwikkelen. De resultaten zo behaald, zullen dan als positieve bekrachtigers een tegenwicht kunnen vormen voor een persoonlijkheidsontwikkeling, die ten gevolge van de handicap zich in negatieve zin had kunnen voltrekken. Zijn bovengenoemde factoren, die mede de persoonlijkheidsontwikkelling van het individu bepalen, niet in voldoend gunstige mate aanwezig, dan is het de taak van een multidisciplinair amputatieteam om deze veranderde bestaansworm, gevolg van de ,,veränderte Körperlichkeit" te leren accepteren of anders gezegd er mee te leren leven.

Naast de gestoorde biologische ontwikkeling, welke invloed kan hebben op de persoonlijkheidsontwikkeling, heeft de amputatie bij de mens als psychosomato-sociale eenheid effecten op zijn sociale ontwikkeling.

,,De volwassenheid wordt niet zoals de jeugd gekenmerkt door turbulente ontwikkelingen op biologisch gebied, die als sterk beinvloedende factoren de richting van het individu bepalen. Als we zouden moeten vaststellen op welk gebied de belangrijkste ontwikkelingen zich voordoen in de volwassenheid, zouden we waarschijnlijk het gebied van de sociale ontwikkeling en aanpassing moeten nemen. De biologisch volwassen mens gaat een lange periode tegemoet waarin hij moet samenleven, samenwerken met anderen. De mens is in hoge mate een sociaal wezen. Hij wordt tot wat hij is door zijn sociale contacten. Dit alles tegen een biologische ondergrond, die moet worden gezien als de lap waarop wordt geborduurd." (Holzhauer 1975.)

De amputatie veroorzaakt een gat in dit borduurstramien. Schering en inslag zijn afwezig en dit gat moet gedicht worden. Draden welke betrekking hadden op a. het huwelijk $b$. het werk en $c$. de maatschappij.

Is dit al vaak uiterst moeilijk ten aanzien van het huwelijk, ten aanzien van werk en maatschappij wordt de volwassen gehandicapte plots geconfron- 
teerd met een situatie, waarnaar de gepensioneende geleidelijk is kunnen grovien.

a. Elke handicap, ontstaan na het sluiten van een huwelijk, houdt risico's in ten anzien van de relatie tussen de partners. Om het even of het gaat om blind heid, doofheid of het gemis van een lidmaat, dan wel een ernstige ziekte of trauma welke tot gehandicapt leven voert (rheuma, M.S., dwarslaesie). Een handicap maakt de ene partner in wisselende mate en frequentie afhankelijk van de ander. Een handicap, vooral wanneer die niet steeds zichtbaar is, leidt maar al te makkelijk tot verontachtzamen dan wel verwaarlozen. In dit verband is het goed erop te wijzen hoeveel grapjes in omloop zijn over doven dan wel slechthorenden, terwijl dit niet of veel minder het geval is met blinden. leder mens kan zich voorstellen wat blind zijn betekent, het tastend zocken in het duister van de nacht. Het totaal niet kunnen horen in onze moderne wereld vol lawaai is veel moeilijker invoelbaar. Op een zintuiglijke handicap in combinatie met een beenamputatie zal in hoofdstuk $V$ nader worden ingegaan.

Tenslotte wordt door een ernstige handicap de zelfwaardering op de proef gesteld. Door een handicap ontstaat snel het gevoel van minderwaardigheid. Bij de bespreking van de onderzoeksresultaten van deze studie zal ter sprake komen hoe in de leeftijdsgroep van 20 tot 65 jaar, die deel uitmaakte van de totaal onderzochte groep van 125 patienten, het diverse malen voor komt dat een huwelijk ontbonden werd na het ontstaan van de handicap. Meestal had deze echtscheiding al plaatsgevonden voordat de patiënt opgenomen werd in het R.C.H. Ontstond deze problematiek na opname in het R.C.H., dan bleek het oplossen hiervan vaak niet mogelijk.

b. Arbeid is een essentieel deel van het leven van de mens, omdat dit aspect van zijn leven in belangrijke mate zijn status bepaalt en hem verbindt met de maatschappij. In de huidige economische crisis, is het verlies van arbeid, niet zoals vroeger, verlies van financiële middelen waardoor armoede onontkoombaar werd. Meer en meer breekt tegenwoordig het besef door hoezeer arbeid, het iets kunnen of mogen presteren, belangrijk is voor thet welzijn van de mens. Werkloosheid is een krachtige negatieve prikkel, ondat daardoor de band tussen de mens en zijn samenleving wordt doorgesneden.

Wanneer twee mensen met elkaar kennis maken is een van de eerste vragen om het gesprek op gang te brengen: , Wat doet u voor werk?" of „, Waar werkt u?"*. Arbeid levert status op, waarbij het groot verschil uitmaakt of men bijwoorbeeld timmerman is bij firma Janssen of bij D.S.M. Waardering van anbeid wordt mede bepaald door diegene waarvoor de arbeid verricht wordt. Secretaresse zijn van de administratieve dienst wordt minder gewaardeerd dan afdelingssecretaresse in een ziekenhuis, welke laatste functie toch weer niet kan rekenen op de status die men heeft als directiesecretaresse. Dat in feite de functie-inhoud weinig verschilt, toont des te meer aan hoe arbeid verweven is met de sociale contacten die men heeft.

c. De gehandicapte weer terug te plaatsen in de maatschappij, in het arbeidsproces met zijn vele sociale aspecten is een der taken van een amputatieteam. Is terugkeer in het oude beroep door de handicap ten gevolge van de 
amputatie niet meer mogelijk, dan kunnen VIA en C.B.H. mede er toe bijdragen het sluitstuk te vormen van de revalidatie.

Op dit moment, nu de VIA pas recent concrete vormen heeft aangenomen en het C.B.H. in statu nascendi is, lijkt het niet juist successen van de VIA als illustratie te gebruiken. Te żjner tijd zullen zeer zeker de VIA-C.B.H.activiteiten, alsmede de behaalde resultaten onderwerp van studie zijn.

Om de noodzaak van VIA en C.B.H. te onderstrepen, als conditio sine qua non voor optimale c.q. maximale revalidatie, zoals gedefinieerd door de W.H.O. in 1968 (Inleiding), moge de volgende casus dienen:

Een man van 29 jaar werd in juni 1974 voor revalidatie opgenomen. Een maknd tevoren overkwam hem een ernstig ongeval als motorrijder, watbij zijn rechter been afgerukt wend, juisi distaal van hef kniegewricht. Bovendien was er een verbrijzelingsfractuur varn het femur, proximal van het kniegewricht. Bovenbeenamputatie rechts was geindiceerd. Een week later werd de man gemobiliseend en hij $\mathrm{kwam}$ snel tot goed lopen met krukken. De verdene tractus anamnese vermeldde geen bijzonderheden.

Hij had een volledige opleiding tot timmerman gevolgd (L.T.S.) en alls zodanig een hall jaar gewerki. Omdat hij meer wilde verdienen nam hij een baan aan in een transportbedrijf en functioneerde tot de dag van het ongeval als vrachtwagenchauffeur op het internationale vrachtverwoer. Hij was gehuwd, maar de amputatie had bijgedragen tot de recente echtscheiding. Hij woonde weer bij zijn ouders. Hobby: fervent motorliefhebber.

Zowel de algemene conditie als de status localis van de amputatiestomp stonden prothesetechnisch een vlotte revalidatie niet in de weg.

De problemen ontstonden toen een tewerkstelling na ontslag ter sprake kwam. Afgezien van de wegenverkeerswetgewing in het buitenland, bleken er toch well grote bezwaren te bestaan om de man als prothesedrager weer te plaatsen als chauffeur op een internationale route. Aanpassing van een der vrachtwagencombinaties zou tem naaste bij f1. 13.000 kosten. De werkgever gaf aan dat zijn chauffeurs reden zonder bijrijder. Dit hield in dat de chauffeur, naast het rijden ook moest laden en lossen, het zeil opbrengen, bevestigen en afhalen en tenslotte wielen verwisselen bij bandenpech. De werkgever karakteriseerde onze patiënt als een man die: , getrouwd was met zijn wagen. Altijd was zijn vrachtwagen van binnen en buiten in goede conditie, de banden op spanning en de lading in orde. Ook de benodigde papieren en declaraties waren keurig ingevuld". Dit om aan te tonen dat ondanks alle technische bezwaren de werkgever bereid was mee te denken. De werkgever was echter terecht van mening dat, zo betrokkene met de uiterste krachtsinspanning toch bovengenoemde activiteiten zou kunnen verrichten, dit zou leiden tot een verminderde rijconditie. Doorslaggevend was tenslotte dat, na een kostbare atanpassing als bovengenoemd, miet alleen chaffeur en vrachtauto aan elkatr gekoppeld zouden zijin, matar ook werkgever en chauffeur. Vermeld dient te worden dat de patient als jonge man van huis was weggelopen om op vrachtaulo's te kunnen rijden.

Een citaat van de psycholoog. "Betrokkene is in zijn leven plotseling met zijn handicap geconfronteerd. Een leven met veel bravour, avontuur als chauffeur bij het internationat wegtransport, kameraadschappelijkheid bij een motorrijdersclub is van het ene moment op het andere geëindigd. Des te meer ervaart bij nu na echtscheiding het alleen zijn; als enige oplossing ziet hij momenteel met een goede prothese gaan functioneren in zijn vroegere leven zowel wat betreft zijn hobby, als ook zijn beroep. Het avontuurlijke alsmede het in de buitenlucht zijn trekı hem aan".

Onze pogingen om de man aan werk te helpen, op basis wan zijn wroegere opleiding tor timmerman, liepen op niets wit.

Tijdens de opname ging hijeen weekend naar de T.T. races in Assen. Naderhand hoorden wij dat hij, temidden van zijn vrienden en wriendinnen en andere motorfans zijn prothese denonstratitef hadl uitgetrokken en, - de prothese aan een touw hangend rond zijn nek -, met krukken het motorfestijn verder had bijgewoond. Jeroen Bosch schetst een geamputeerde die zijn verdord been, om zijn nek hangend aan een eind touw, demonstratief meedraagt om te bewijzen dat hij niet behoort tot de ,validi mendicantes". (Fig. 9) Vijf eeuwen later wordt deze door Bosch geschetste figuur ten tonele gewoerd door een ander, die wil demonstreren dat hij we behoort tot de „validi mendicantes" : de man die zijn hand binnen W.A.O.-verband moet ophouden, omdat 


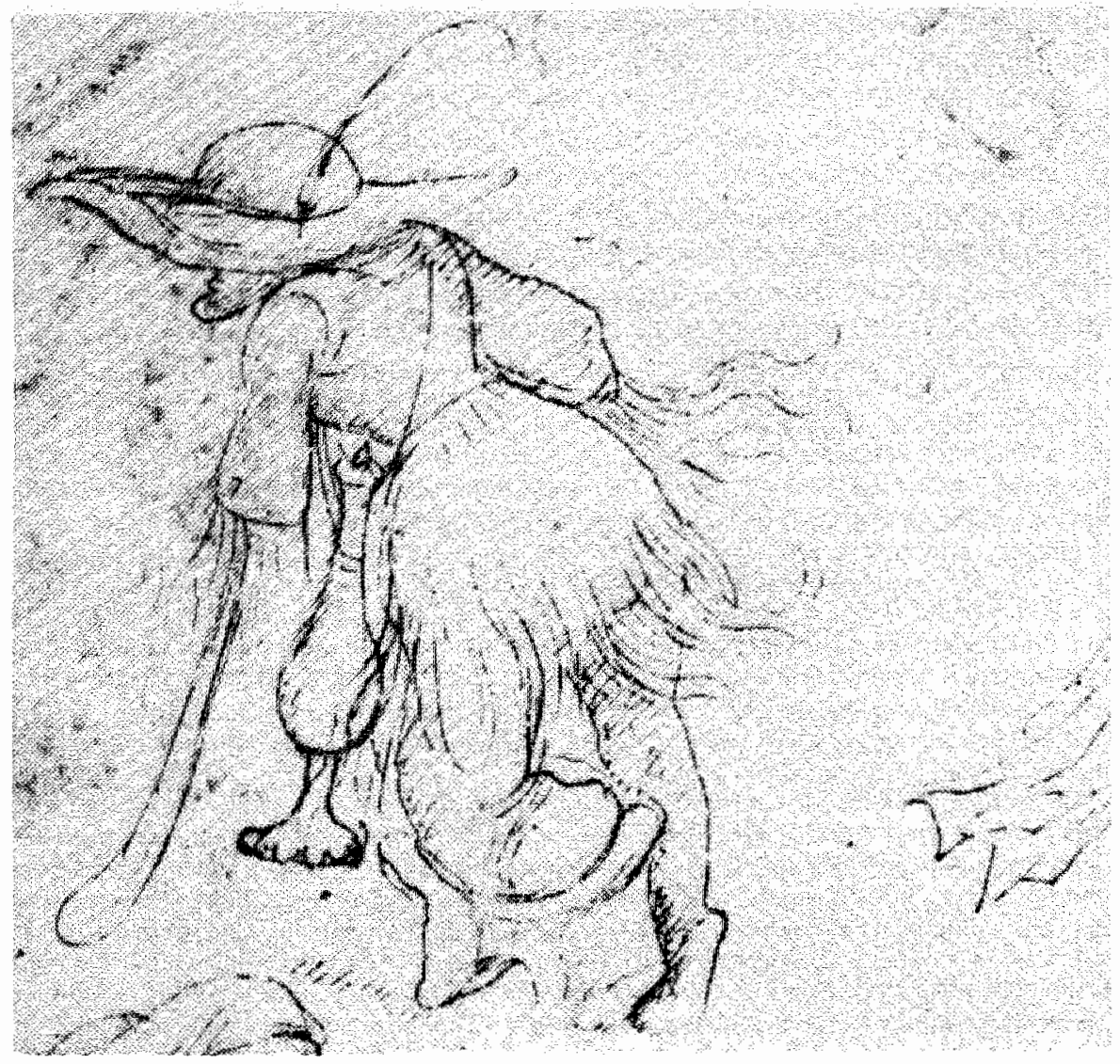

Fig. 9: Kreupele bedelaar (Jheronimus Bosch).

er geen werk voor hem is. Immers, de man kan met zijn prothese lopen met of zonder hulp van een $\$$ tok. Volgens de classificatie van Vaucher een prothesetechnisch fraai resultaat (5 tot 6$)$. Ten aanzien van de doelstelling van de revalidatie echter een grandioos debacle.

\section{3. De problemen rond het kind en de adolescent.}

Elke handicap, elke uiting van een afwijkend lichaam roept bij vrijwel iedere gezonde op een gegeven moment toch in meer of mindere mate medelijden op. Menig chirurg lijkt uit een mogelijk onbewuste drang tot zelfbehoud ,, hard" bij het uitoefenen van zijn beroep. Toch zal hij toegeven dat hij nog steeds emotioneel geraakt wordt, wanneer een kind een amputatie van een lidmaat moet ondergaan. Voor het kind en de adolescent lijkt na amputatie immers de wereld in elkaar te storten.

Het zijn echter meestal de ouders naar wie de aandacht in eerste instantie moet uitgaan. Zij voelen zich verantwoordelijk voor de invaliditeit van hun kind, zowel bij congenitale- als verworven amputaties.

Kinderen en opgroeiende jonge mensen blijken vaak begenadigd met een 
groot vermogen de handicap te kunnen compenseren. Hun revalidatie na prothesevoorziening gelukt vaak spelenderwijs. Het lijkt of de bewegingsdrang, horend bij deze leeftijd, het kind sneller weer ambulant maskt. Een kind van nog geen 2 jaar met een bovenbeenamputatie op basis wan een maligne proces, en op een leeftijd waarop de geringe verbale communicatie het leerproces van ,,weer lopen leren" leek te zullen bemoeilijken, bewees het tegendeel. De prothese kreeg alleen aandacht, wanneer deze het spel duidelijk stoorde en niet meteen wilde passen in het zich ontwikkelend lichaamsschema. De door het groeiproces regelmatig te vervaardigen prothesen zijn twee maanden na aflevering al toe aan reparatie. Juist dit intensieve gebruik geeft de prothesemaker de voldoening dat hij trots mag zijn op het vervaardigde kunstbeen. De prothese, die door het kind niet als een surrogaat wordt beleefd en zijn ontplooiïngsdrang, althans wat betreft zijn motoriek, niet in de weg staat.

Een uitzondering dient gemaakt voor kinderen met ernstige congenitale misvormingen of meervoudige verworven amputaties. Door het vaak noodzakelijk langdurig verblijf in revalidatiecentra verliezen zij min of meer het contact met hun ouders. Zij voelen zich soms meer op hun gemak in de kliniek dan thuis. Ook hier zijn de psychische problemen van de ouders minstens zo groot. Medelijden en bemoederen, met als tegenpool het afwijzen van een zwaar gehandicapt kind, kunnen dan de terugkeer naar en de invoeging in eigen milieu ernstig belemmeren. Dit milieu wordt dan later tot de werkelijke handicap.

In tegenstelling hiermee speelt deze Umwelt bij de volwassene en de bejaarde mens van meet af aan een grote rol. Uitstoting uit de maatschappij, economische verzwakking, vervreemding in het gezin, hulpbehoevendheid, huisvestingsproblemen en inhaerent hieraan maatschappelijke vereenzaming en geestelijke nood zijn problemen waarmee het kind en de adolescent in eerste instantie niet te maken krijgen.

Wil het kind en de adolescent deze problemen straks wel het hoofd kunnen bieden, dan is evident dat in het mens-machine-milieu systeem de biologische ontwikkeling van het groeiend individu de meeste aandacht zal moeten krijngen, wanneer een beenamputatie niet te vermijden is. De chirurg die een beenamputatie bij een kind moet verrichten, dient zich te realiseren dat hij dit doet in groeiend en meestal zeer vitaal weefsel. Hier gelden andere normen.

Trauma ( $75 \%$ tot $80 \%$ ) en tumoren ( $5 \%$ tot $10 \%$ ) vormen bij het kind de belangrijkste indicatie tot amputatie. Bij de volwassene en de bejaarde mens kan het vaatlijden ( $80 \%$ tot $90 \%$ ) en ver op de tweede plaats het trauma ( $10 \%$ tot $15 \%$ ) reden zijn tot amputatie over te gaan. Is een vaatafsluiting bij een kind wel mogelijk, dan is dit meestal de dramatische complicatie van het oorzakelijk lijden. (Tabel 3)

Met betrekking tot de maligne tumoren lijken enkele opmerkingen op hun plaats, ook al heeft het R.C.H. (gelukkig) nog geen grote ervaring in deze.

Acht kinderen werden voor revalidatie aangeboden, nadat een beenamputatie was verricht op grond van een maligne proces. Hun leeftijd varieerde van $11 / 2$ tot 19 jaar.

Kostbare tijd gaat vaak verloren tussen het optreden van de klachten en de definitieve amputatie. Bij deze 8 patiënten lag deze tijd tussen 1 en 12 maan- 
1. Geforlswersehthisge

a) Aritarienll

Arteriosklerose, diabetische Angiopathie, Morbus Bürger

Embolien

Sepsis (Memingokokken, Preumokokken)

Allergischo Reaktionen

Diagnostische Eingriffe (Angiographie, Arterienpunktion)

Arterienwerlatzungen

b) Venos

c) Lyphatisch

2. Trauma

3. Niche traumarische infekte

4. Tumoren

5. Neuralogische Erkrankungen

$\begin{array}{ll}0 & 80-90 \% \\ \text { selten } & \\ \text { selten } & \text { sehr selten } \\ \text { sehr selten } & \text { sehr selten } \\ \text { sehr selten } & \text { sehr seltem } \\ \text { siehe wnten } & \text { siehe unten } \\ \text { sehr selten } & \text { seiten } \\ \text { unbekannt } & \text { sehr selten } \\ 75-80 \% & 10-15 \% \\ \text { seltem } & \text { selten } \\ 5-10 \% & 2-3 \% \\ \text { unbekannt } & \text { seltem }\end{array}$

Tabel 3: Oorzaken van amputaties.

den met een gemiddelde van 4 maanden. Men kan aanwoeren dat deze lange tijd ook beinvloed zal worden door het overigens begrijpelijke protest van ouders en patiënt en het aanvankelijk afwijzen van het voorstel tot en de noodzaak van amputatie. De soms vage klachten in thet begin of het schijnbaar onschuldig karakter daarvan dragen veelal slechts bij tot bovengenoemde houding van ouders en patiënt.

In verband met de termijn tussen klachtenbegin en ingreep merkt van der Heul (1968) op: ,, Naar onze ervaring, berustend op de beoordeling van bijna 2500 botprocessen, geregistreerd in het archief van de Commissie voor beentumoren, komt het nogal eens voor, dat weefsel, verkregen door een biopsie uit een bothaard, ongeschikt blijkt te zijn voor histologische diagnostiek. De oorzaken hiervan zijn zeer uiteenlopend, zoalls geringe hoeveelheid, mechanische beschadiging, niet representatief zijn voor het onderliggend proces etc. ". Hij vervolgt: ,, daarbij komt dat de reactieve weefselveranderingen als gevolg van de eerste biopsie, de histologische interpretatie van een tweede in hoge mate kunnen bemoeilijken. Mislukken van de biopsie, in de zin dat geen of onvoldoende dan wel ongeschikt materiaal wordt verkregen, moet dan ook worden voorkomen". van der Heul stelt: , In dit verband moet er met nadruk op worden gewezen dat therapeutische röntgenbestraling niet mag beginnen (respectievelijk worden voortgezet) alvorens met zekerheid een histologische diagnose is gesteld: anders zal immers in een aantal gevallen ten onrechte worden bestraald, of zal het tumorweefsel zo worden beschadigd, dat bij een nieuwe biopsie, in geval deze nodig wordt geacht, het weefsel minder geschikt of zelfs ongeschikt is voor histologische diagnostiek".

Deze aanwijzingen betreffende de plaats van de biopsie, alsmede de hoedanigheid van het biopsiemateriaal doen het vermoeden rijzen dat bekorting van de tijd tussen begin van klachten en definitieve amputatie zeker wel mogelijk is in bepaalde gevallen. Onze 8 patiënten ondergingen $6 x$ een bovenbeenamputatie en $2 x$ een heupexarticulatie. De maligne tumor was bij de patiënten met een bovenbeenamputatie primair onder het kniegewricht gelokaliseerd. Men kan zich afvragen waarom een exarticulatie door de knie niet overwogen werd. In hoofdstuk VII zal uitgebreid op de knie-exarticulatie 
worden ingegaan, welke ook voor het kind, vergeleken met een bovenbeenamputatie, belangrijke voordelen biedt.

Zoals boven reeds werd gesteld, berust het merendeel van amputaties bij kinderen en adolescenten op een trauma. Elke chirurg is op de hoogte van de diverse gangbare amputatieniveau's. Dit niveau, deze indeling stamt uit het begin van deze eeuw toen Zur Verth, Kreutz, Lange en Waterman een indeling maakten in min of meer, ,wertvolle Abschnitte". Bekend is dat zij te weinig rekening hielden met de weke delen rond het benig gedeelte van de amputatiestomp. Het gevolg was dat, toen atherosclerose de voornaamste indicatie werd tot amputeren, andere maatstaven aangelegd dienden te worden. De optredende spieratrofie in slecht doorbloed weefsel gaf eerder klachten en leidde snel tot een onvermogen de prothese naar behoren in te schakelen. De literatuur omtrent amputatietechnieken is sinds de vijftiger jaren zo veelomvattend geworden, dat eensluidende operatietechnieken nauwelijks opgesteld kunnen worden. Het is dus ook niet verwonderlijk dat een chirurg niet of nauwelijks voldoende op de hoogte kan zijn van de diverse mogelijkheden, vergeleken met de kennis en kunde die hij heeft van bijvoorbeeld de fractururbehandeling. Op de tweede plats is het evenmin verwonderlijk dat, waar in een algemeen ziekenhuis per jaar hooguit één kind of adolescent een beenamputatie moet ondergaan, hij dezelfde maatstaven aanlegt zoals deze gelden als ware het een amputatie op grond van atherosclerose, al of niet na een niet succesvolle vasoreconstructieve operatie. Voor het kind en de adolescent geldt dat de chirurg primair de taak heeft te vechten voor elke centimeter die behouden kan blijven, zeker waar het centimeters betreft waarbinnen epiphysairschijwen dan wel gewrichten gelokaliseerd zijn. De benige lengte van de amputatiestomp is hier nog net zo belangrijk alls in de tijd van Zur Verth c.s. Het verlangen naar een musculeuze en goed gepolsterde amputatiestomp wordt bij jeugdigen tot een secundaire eis. De uiteindelijke, na afsluiting van het groeiproces te verwachten lengte van de amputatiestomp, hangt ten nauwste samen met het amputatieniveau in relatie tot de epiphysairschijven. De potentie van de epiphysairschijven definieert men in Frankrijk als: ,,Loin du coude, près du genou". (Fig. 10)

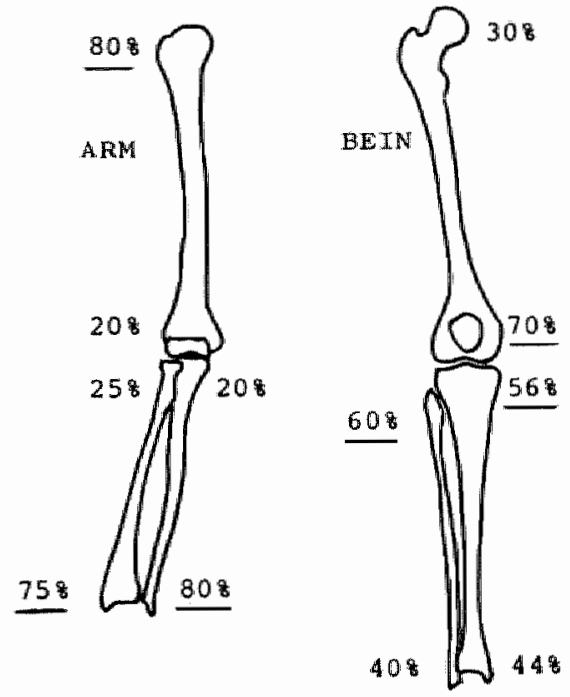

Fig. 10: Bijdrage van de epifysairschijven aan de groei van de onderste en bovenste extremiteit. 
De amputatietechnieken en de amputatieniveau's bij kinderen eisen dan ook en aparte beschouwing.

Waar de epiphysairschijwen van femurkop en trochanter major borg staan voor een goed uitgebalanceerd heupgewricht, is de groei van de femurschacht voornamelijk afhankelijk van de distale femurepiphyse. Bij een amputatie op jeugdige leeftijd door de femurschacht, blijt deze femurrest, vergeleken met het andere been in groei achter, terwijl de weke delen zich nagenoeg normaal ontwikkelen. Het gevolg is een wanverhouding tussen het spichtige femurschachtgedeelte en de weke delen, hetgeen eens te meer duideljk wordt narmate op jeugdiger leeftijd werd geamputeend. De in groei achtergebleven lemurschacht gedraagt zich ten opzichte van de royale weke delen massa als de klepel in een klok. De femurstomp is niet meer bij machte om elke bewegingsuitslag te laten volgen door een nagenoeg gelijke excursie wan de prothesekoker, terwijl dit toch het doel is van elke goed functionerende amputatiestomp. Trimmen van de weke delen lost het probleem niet op, want de totale lengte van de stomp wordt kleiner en daarmee de krachtarm welke de prothesekoker moet bedienen.

Osteotomiën en operatietechnieken, bedoeld om de femurschacht te verlengen, zijn niet van gevaar ontbloot, gezien dle kansen op pseudarthrosis en infectie, welke tot desastreuze gevolgen aanleiding kunnen geven. De totaal contactprothese is, prothesetechnisch gezien, het meest aangewezen, wil men de gevaren van een operatieve reconstructrie vermijden.

Hoe korter de amputatiestomp, des te groter is de kans op wanverhouding met betrekking tot de musculatuur. Immers, de adductoren missen snel hun insertie terwijl de pelvitrochantaire musculatuur volledig intact blift. De daaruit voortvloeiende problemen voor de prothesebouwer maakt, gezien de toenemende abductieneiging, een functionele prothesevoorziening uiterst moeilijk. Ook in het sagittale vlak wordt de extenderende werking van de gluteaalmusculatuur eerder opgeofferd dan de insertie van de musculus iliopsoas, die zo tot flexiecontracturen kan voeren. Juist de myoplastische en myodesetechnieken, welke bij volwassen geamputeerden bedoeld zijn om een goed evenwicht te bereiken tussen a- en antagonisten, schieten soms hun doel voorbij wanneer zij loegepast worden bij een nog groeiend individu. Het is namelijk moeilijk te voorspellen hoe groot het achterblijven in de groei van het femur zal zijn ten opzichte van de voorspoedige en ongestoorde groei van de weke delen, ook na myoplastiek en myodese. Bovendien is zulks eigenlijk alleen maar mogelijk bij de amputatie op grond van een maligne tumor. Nog te vaak wordt bij traumata ver proximaal van het letsel geamputeerd om de risico's van de dichtbijgelegen infectiehaarden en necrose te vermijden. "Traumata, dikwijls vergezeld van infecties en weefselnecrose blijken dan in de praktijk vaak betere resultaten te geven na een guillotine-amputatie, gevolgd door een secundaire stompplastiek" aldus Baumgartner (1977).

Wanneer zich na deze guillotine-amputatietechniek nieuw granulatieweefsel gevormd heeft met daarnaast bestaande huiddefecten, komt de vraag aan de orde of het juist is de defecten te bedekken met huidtransplantaten. Ondanks de voordelen heeft snelle bedekking van het defect en daaruit voortvloeiend snelle mobilisatie toch bepaalde nadelen., zoals littekens op de donorplaats, mogelijk keloidvorming bij zwaailappen met hieruit resulteren- 
de problemen na prothesevoorziening. Hierbij moet men bedenken dat het regeneratievermogen van jeugdig weefsel niet te vergelijken is met dat op oudere leeftijd. Huidtransplantatie kan hier dan tot een overbodige en tot een allerlei problemen oproepende ingreep worden. Een snelle epithelialisatie bij een jeugdig individu biedt dan volgens Baumgartner (1977) de volgende voordelen:

"- geen overbodige operatie.

- geen littekens op de donorplaats.

- minder adhaerent zijn van de huid aan de onderlaag en zodoende betere kwaliteit van de stomphuid.

- beter herstel van de sensibiliteit vergeleken met huidtransplantaten".

Tenslotte zij vermeld dat bovenbeenamputatie op jeugdige leeftijd altijd aanleiding geeft tot verminderde groei van de corresponderende bekkenhelft en wel in grotere mate dan bij exarticulatie in het kniegewricht het geval is.

\section{Ter illustratie de volgende casus:}

In mei 1973 werd op een chirurgische afdeling een meisje van 11 jaar opgenomen ma een ernstig trauma van het linker been. Er was een enorme Z-vormige wond aan het bovenbeen met uitgebreide spierletsels. Verder bestond er een distale femurfractuur mel linke verkorting en dislocatie. Onmiddellijk werd fosfaattoxoïd en antigasgangreenserum toegediend. De fracturen werden dezellde dag behandeld middels osteosynthese. De arteria femoralis pulseende ter hoogte van de fractuur. Meer distaal waren geen pulsaties te voelen. Ook de volgende dag waren de perifere pulsaties afwezig. Er werd spoedarteriografie verricht. Deze toonde een stop in de arteria femoralis ter hoogte van de fractuur. Hierop werd direct ingegrepen. Een grote thrombus werd uit de arteria femoralis verwijderd. Hierna kwam bloed wan proximaal en distaal. De arteriële incisie werd gesloten met een weneuze verwijdingspatch. Helaas herstelde de circulatie van het been niet en wegens uitbreiding van de necrose tot boven de knie volgde een week na het trauma een bovenbeenamputatie na verwijdering van het osteosynthesemateriaal. Het meisje kreeg een intensieve antibioticakutr, aangezien er een lichte sepsis bestond.

Postoperatief deden zich geen complicaties voor en 5 weken later werd het meisje voor verdere revalidatie in Hoensbroeck opgenomen.

Het been was geamputeerd $10 \mathrm{~cm}$ boven de mediale gewrichtsspleet van de knie. Het litteken was terminaal gelokaliseerd en duidelijk pijnlijk bij palpatie. Dit gold eigenlijk voor het gehele stomputeinde. Al snel was duidelifk dat in het stomputeinde nog een pathologisch proces aanwezig was. De BSE bij opname $17 \mathrm{~mm}$, steeg na 10 dagen tot $30 \mathrm{~mm}$. Een röntgentfoto liet een sequester zien aan het stompuiteinde. (Fig. 11) Deze sequester werd een week later ver wijgerd. Hiema kon prothesevoorziening platsvinden en deze verliep zonder problemen.

Nat ontslag wond regelmatig controle plaats op het prothesespreekuur. Gezien het groeiproces, moest de prothese regelmatig aangepast worden. Bij opname destijds bedroeg de lengte 1.40 meter, het gewicht $39,5 \mathrm{~kg}$. Momenteel is dit respectievelijk 1.60 meter en $54 \mathrm{~kg}$. Aanwankelijk liep het meisje zonder zwikken. Langzalam aan zagen we hoe bij het lopen de laterale kokerwand naar lateraal ging wijken, wanneer het prothesebeen belast werd. De spitse en in groei achtergebleven femurrest kan geen voldoende steun vinden tegen de laterale kokerwand door de overvloedige weke delen massa tussen femurrest en kokerwand. (Fig. 12) Het gevolg hiervan is een positief symptoom wan Trendelenburg bij belasten van het prothesebeen met als gevolg zwikken bij het lopen. Lag bij de operatie aanvankelijk het amputatieniveau $10 \mathrm{~cm}$ boven de mediale gewrichtsspleet der knie, nu is dit $14 \mathrm{~cm}$ geworden. Duidelijk is ook hoe de linker bekkenhelft achtergebleven is vergeleken met de rechter kant. (Fig. 13)

Primair behoeft ook de onderbeenamputatie een zeer conservatieve instelling, met als enige uitzondering de amputatie op basis van een maligne proces. Bij een traumatische amputatie wordt het geduld van de chirurg en zijn kennis van reconstructieve ingrepen soms zwaar op de proef gesteld. Vaak zijn 


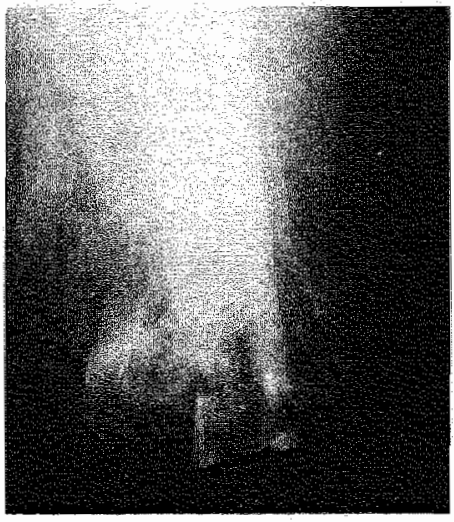

Fig. 11: Sequestrering in distale

femuramputatiestomp.

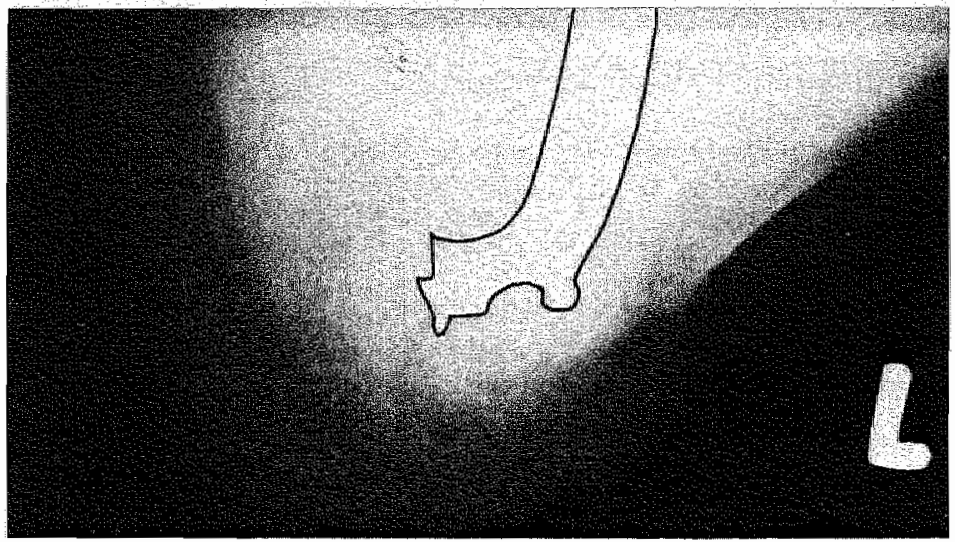

Fig. 12: Distale femuramputatiestomp in overvloedige weke delen massa.

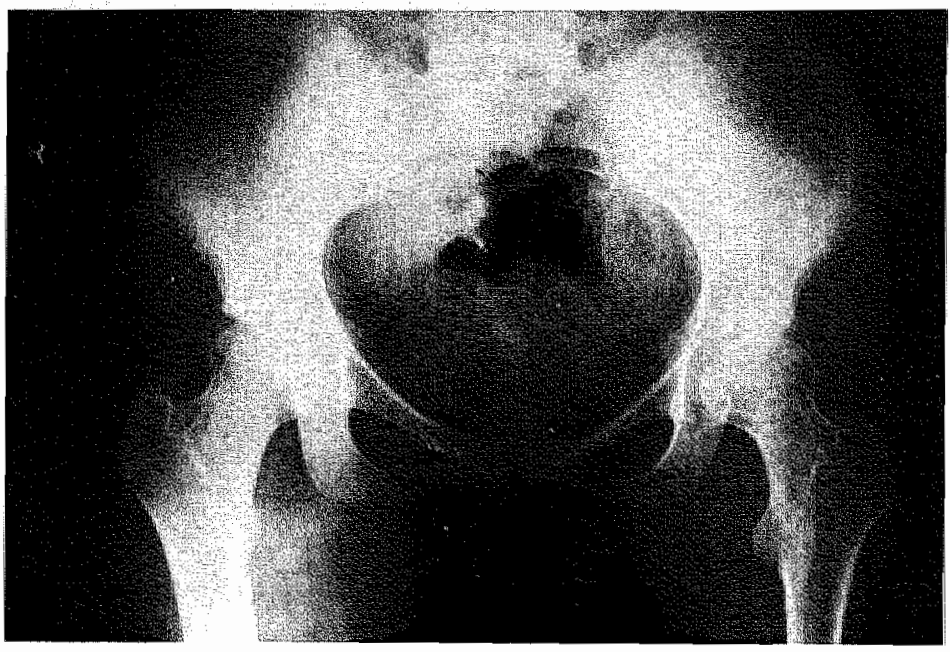

Fig. 13: Achterbliwen in groei van linker bekkenhelft en femur na transfemorale amputatie. 
meerdere ingrepen noodzakelijk om een optimale amputatiestomp te verkrijgen. Wint hij echter het gevecht om elke centimeter, dan zal dit de duur van de revalidatie verkorten en op langere termijn de mate van invaliditeit gunstig beïnvloeden. De chirurg, die dit doel voor ogen heeft, weet zich gesteund door het vaak verrassend grote regeneratievermogen van jeugdig weefsel.

Er wordt wel eens gesteld dat een onderbeenamputatie functioneel niet méér zou betekenen dan het gemis van de woet. De lengte van de onderbeenstomp bepaalt echter de krachtarm, terwijl door deze lengte en de daaruit voortvloeiende prothesekeuze het contact tussen stomp en prothese meer of minder geïntensiveerd wordt, en dus ook de proprioceptieve informatie, voortkomend uit het bodemcontact. Wanneer men dus, gedwongen door een slecht operatieresultaat, een stomprevisie moet verrichten, dan levert een $15 \mathrm{~cm}$ lange onderbeenstomp bij inkorting van $1 \mathrm{~cm}$ geen praktische problemen op. Een zelfde verkorting bij een $5 \mathrm{~cm}$ lange onderbeenstomp betekent echter een verkorting van $20 \%$.

Belangrijk bij de onderbeenamputatie op jeugdige leeftijd is de ervaring dat tibia en fibula sneller groeien dan de weke delen, terwijl de groeisnelheid van de fibula overweegt vergeleken met de tibia. Het gevolg hiervan kan zijn dat na een bepaald tijdsverloop, tibia en fibula de weke delen dreigen te perforeren, terwijl de langere fibula een varusstand van de tibia kan veroorzaken. Deze toestand kan al binnen enkele maanden ontstaan. McKenzie (1960) stelt: ,Dit wordt nog verergerd door het ervaringsfeit dat tibia en fibula konisch uitgroeien. Men zou kunnen veronderstellen dat men door middel van epiphysiodese dit fenomeen kan tegenhouden". McKenzie heeft echter bezwaren tegen deze procedure. Epiphysiodese door middel van palpabele krammen leidt enerzijds tot moeilijkheden bij het fitten van de prothesekoker; anderzijds is zijn ervaring dat door het dragen van de prothese migreren van epiphysiodesemateriaal kan plaatsvinden. Indien dit optreedt is het gevolg een gedeformeerde amputatiestomp. Tenslotte, zelfs al zou de epiphysiodese niet de bovengenoemde moeilijkheden tot gevolg hebben, dan nog kunnen de littekens ter plaatse naderhand blijvend een pijnloos gebruik wan de prothese belemmeren. Mc. Kenzie (1960) zegt dat alleen bij een zeer korte amputatiestomp epiphysiodese overwogen moet worden, omdat hier enerzijds de disproportionele groei snel aanleiding kan zijn tot corrigerende operaties, terwijl anderzijds weinig weke delen resten, die een recidiverende correctie mogelijk maken. Ondanks alle bezwaren tegen epiphysiodese geeft hij aan deze ingreep de voorkeur, wanneer dit het sparen van een gewricht tot gevolg heeft.

Zo blifft over de ervaring dat na conventionele amputatie van tibia en fibula bij kinderen de weke delen onder spanning komen te staan. Er ontstaan bursae, welke pijnijjk zijn en ontstoken kunnen raken. Bij een revisie van de fibula in de zin van inkorten op conservatieve wijze mag de chirurg zich verzekerd weten van enkele recidieven en dat des te meer wanneer de patiënt jonger is en dus het groeiproces nog jaren kan duren. Zowel bij de primaire operatie als bij een re-amputatie dan wel stompcorrectie wordt, afhankelijk van de stomplengte, aanbevolen tibia en fibula met elkaar te verbinden volgens de techniek van Dederich. (Fig. 14) Dederich (1970, 1973) prepareert 


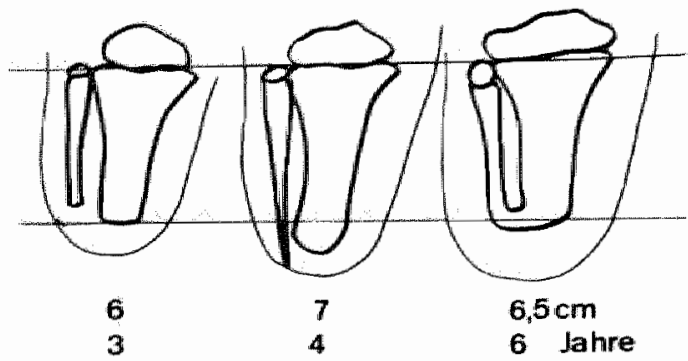

Fig. 14: Traumatische amputatie op 3-jarige leeftijd. De korte stomp meet $6 \mathrm{~cm}$. I jaar later perforatie van de weke delew door overgroei van fibula. Stompcorrectie in de zin van een botbrug tussen tibia en fibula volgens Dederich met verlies van 1,5 cm bot. Op 6-jarige leeftijd een deels belastbare amputatiestomp van $6,5 \mathrm{~cm}$.

zowel aan tibia als fibula periostlapjes van $11 / 2$ tot $2 \mathrm{~cm}$ lengte, voorzien van botchips, welke lapjes na afronden van tibia en fibula uiteindelijk met elkaar worden verbonden en zo, tot een stevige beenbrug uitgroeiend, tibia- en fibulastomp met elkaar verbinden. Aangezien voor het maken van deze botbrug de benige stomp $1 / 2$ tot $2 \mathrm{~cm}$ korter wordt, is deze methode niet aan te bevelen bij geringe stomplengte, dat wil zeggen wanneer de benige stomp slechts een kwart van het totale onderbeen gaat uitmaken. In dat geval stelt Baumgartner (1977) dat bij een extreem korte fibulastomp deze beter in toto verwijderd kan worden. Een zeer korte fibula, dat wil zeggen een fibula waarvan naast het capitulum nog slechts 1 tot $2 \mathrm{~cm}$ diafyse rest, heeft meer nadelen dan voordelen. De pees van de musculus biceps femoris zal op den duur deze extreem korte fibularest in abductie en hyperextensie plaatsen. Dit meer dan normaal prominerend fibulakopje kan geen druk door de prothese verdragen. Door het verwijderen van de fibularest wordt nu de laterale helft van het tibiaplateau volledig belastbaar. Voor de bicepspees wordt een nieuwe insertie gevonden door deze te begraven en te hechten in een subperiostaal kanaal, proximaal aan de laterale tibiacondyl.

Volgens Dederich (1970) zou een onderbeenamputatie bij een kind juist myoplastiek vereisen. Door myodese en myoplastiek groeien de rond de benige amputatiestomp geformeerde spiergroepen mee. De kans op perforeren van de weke delen is dan kleiner, vergeleken met de conventionele amputatietechniek zonder botbrug en zonder myodese en myoplastiek.

Zoals boven reeds vermeld, kan het verschil in groeisnelheid tussen fibula en tibia tot een varusstand van de tibia aanleiding geven. Is deze varusstand niet te groot, dan kan de prothesemaker dit opvangen in de prothesekoker. Indien echter deze varusstand aanleiding geeft tot grotere belasting van het mediale compartiment van het kniegewricht, dan behoort een valgiserende osteotomie tot de mogelijk heden, echter alleen uit te voeren na sluiting van de epiphysairschijven.

Uit het bovenstaande volgt dat bij een snellere groei door tibia en fibula, vergeleken met de weke delen, het juist prepareren van de bedlekkende huidspierlappen niet gemakkelijk kan zijn. Bij een trauma zijn de weke delen vaak oedemateus. De ten tijde van de operatie gekozen relatief krappe huidspierbedekking kan dan, na verdwijnen van het oedeem, toch een overtollige weke delenmuts te zien geven. Toch is deze benadering beter, zelfs wanneer naderhand correctie van de weke delen noodzakelijk is. Een te krap gekozen weke delen bedekking impliceert het gevaar van necrose, die ook bij het kind niet onderschat mag worden. Necrotomie betekent immers vaak ook een inkorten van de benige stomp, hetgeen tot elke prijs voorkomen moet 
worden. Algemene regel is dus de amputatiestomp zo lang mogelijk te maken als de voorhanden zijnde pathologie toelaat. Een exarticulatie door de knie lijkt bij kinderen een goed alternatief, aangezien de problemen van het groelproces niet in dezelfde mate de aandacht vragen, maar dit betekent wel het opofferen van een functionerend gewricht.

In het kader van deze verhandeling over de te amputeren jeugdige patiënt zijn nog enkele opmerkingen van essentieel belang. De keuze van het amputatieniveau voor wat betreft de weke delen dient bijna gierig te geschieden. Kleur en contractiliteit van de musculatuur dienen deze keuze te bepalen. Zijn de bevindingen bij het prepareren van de ventrale lap niet bevredigend, dan dient $2 \mathrm{~cm}$ (twee centimeter) proximaler opnieuw de toestand van de musculatuur beoordeeld te worden. Dit vervolgens tot men het niveau onder de tuberositas tibiae bereikt heeft. Is op dit niveau de vitaliteit van het weefsel nog niet bevredigend, dan kan men beter de musculatuur van de tibialis anterior loge alsmede de peroneaalmusculatuur volledig excideren, vooropgesteld dat een goed doorbloede dorsale huidspierlap geformeerd kan worden ter bedekking van de stomp.

Bij een amputatie in het distale derde deel van het onderbeen kunnen problemen ontstaan, omdat op dit niveau de voorhanden zijnde musculatuur overgaat in het peesblad. Soms is dan aan te bevelen, gezien de totale lengte van de stomp, tibia en fibula 2 tot $3 \mathrm{~cm}$ proximaler te amputeren en alleen de peroneaalmusculatuur als bedekking te gebruiken, welke musculatuur distaler dan de musculus triceps surae in het peesblad overgaat.

$\mathrm{Bij}$ een middellange amputatiestomp, dat wil zeggen een stomp welke een derde tot de helft van de tibialengte inhoudt, is vaak teveel musculatuur aanwezig, hetgeen moeilijkheden bij de prothesevoorziening kan geven. Gebruikt men de totale dorsale huidspierlap als bedekking, dan is de stomp distaal breder en plomper dan ter hoogte van het ligamentum patellae. Het terminale deel van de amputatiestomp kan dan de entree van de prothesekoker niet passeren. Het excideren van de diepe flexoren kan dan zonder bezwaar geschieden, ten behoeve van de prothese-aanpassing. Excisie van de diepe flexoren, alsmede de musculus soleus wordt ook aanbevolen bij korte amputatiestompen gezien hetzelfde euvel voor de prothesevoorziening, indien dit wordt nagelaten.

Bij amputaties hebben gekoelde oscillerende zagen uiteraard de voorkeur boven het obsoleet geworden gebruik van de handzaag.

Eveneens obsoleet is de behandeling van de zenuwen middels kwetsen of het infiltreren met alcohol. Een ligatuur van het zenuwuiteinde voorkomt niet het opnieuw uitgroeien van neurofibrillen, maar kan wel aangewezen zijn wanneer de begeleidende vaten blloeden.

De volgende casus moge de geschetste onderbeenamputatieproblemen verduidelijken.

Een jongen, geboren in 1963, werd in 1974 opgenomen op een chirurgische afdeling, nadat hij als duopassagier op een motorfiets betrokken was bij eeri ongeval.

Er werd een gecompliceerde fractura cruris, alsmede een gecompliceerde femurfractur, beiden links, vastgesteld. De femurfractubr werd door middel van A.O.-plaat osteosynthese behandeld. Een week na opname moest vanwege arteriële circulatiestoornissen overgegaan worden tot een onderbeenamputatie op conventionele wijze. (Fig. 15 en 16) Het postoperatieve herstel was langzaam door ontsteking van diverse wonden 

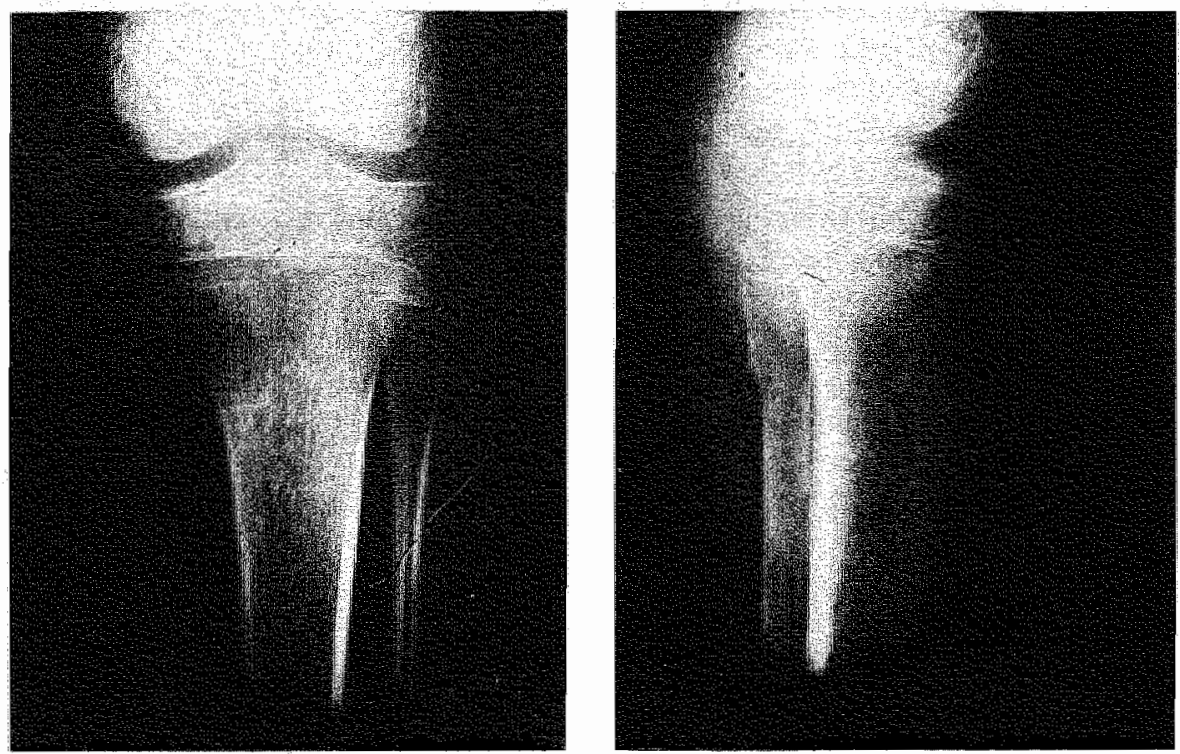

Fig. 15: Fig 16: Onderbeenamputatie op 12-jarige leeftijd.
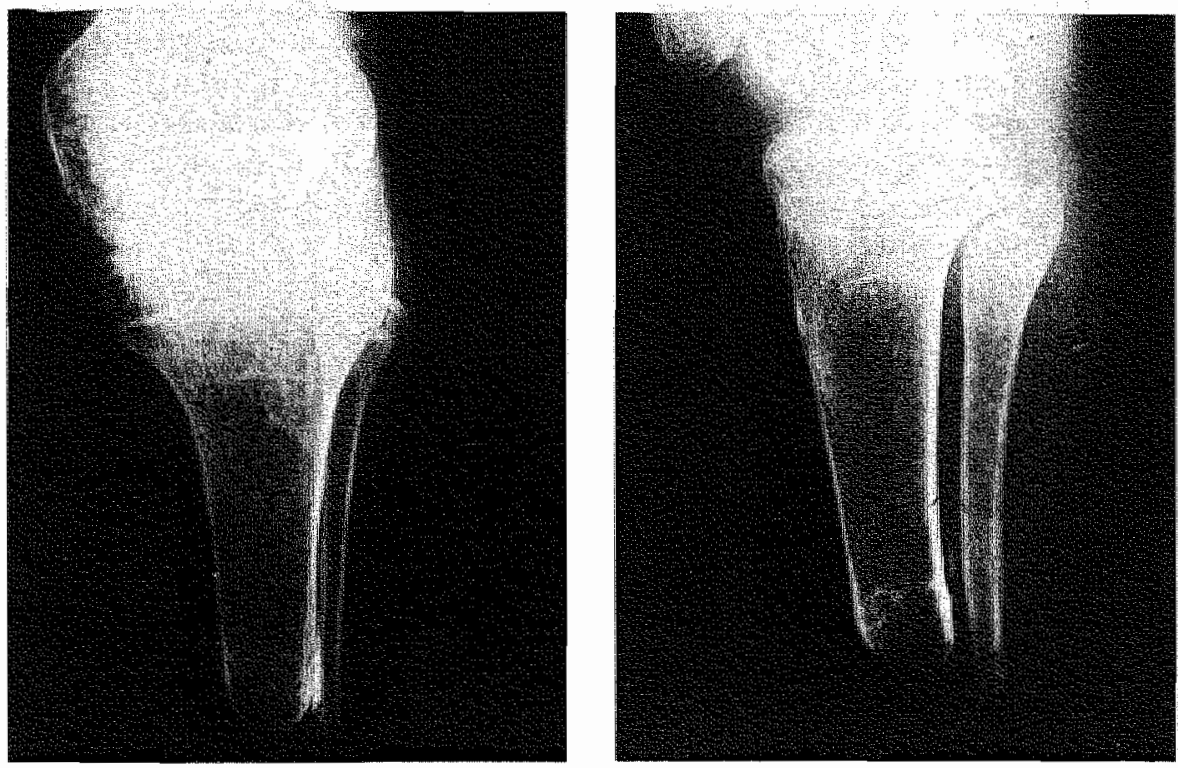

Fig. 17: Fig. 18: Onderbeenamputatie net overgroei van fibula, 3 jaar later. 
Begin 1975 was de femurfractuur oefenstabiel en volgde opname in the revalidatiecentrum. Algemeen intern onderzoek was zonder pathologie, hetgeen ook het gevall was voor het niet getroffen deel van het bewegingsapparaat. De linker heup toonde een flexilecontractur van $10^{\circ}$ en enige beperking van de endo- en exorotatie. De anteflexie liep van $0^{\circ}$ to $70^{\circ}$. De linker knie toonde een flexie welke van $0^{\circ}$ tor $10^{\circ}$ mogelijk was. De kniestabiliteit was normal.

Het linker onderbeen was geamputeerd $15 \mathrm{~cm}$ distal van de mediale gewrichtsspleet van de knie en het litteken, ventro-terminaal gelokaliseerd, was nog niet volledig genezen. Zowel de mobilisatie van de linker knie, alsmede de consolidatie wan de femurfacum lieten lang op zich wachten. Vier maanden na opname kreeg de jongen een conventionele prothese en kwam vlot tot een fraai looppatroon.

Polliklinisch werd hij regelmatig op het prothesespreekutur teruggezien en tot nu toe zijn ergeen klachten, terwijl regelmatig de prothese i.v.m. de groei gewijzigd wordt.

De röntgenfoto bij opname, begin 1975, laat een conventioneel geamputeerde tibia en tibula zien. De röntgenfoto, dine jaar later, toont een spits toelopende fibula welke beduidend langer is dan de tibia, terwijl deze tibia vergeleken met 1975 al een geringe varusstand heeft angenomen. (Fig. 17 en 18) De weke delen bedekking is niet meer regelmatig. (Fig. 19) Klachten zijn er evenwel (nog) niet. De jongen is momenteel 15 jatar en bijna met betrekking tot de epiphysairschijven van het onderbeen volgroeid. Bij her ontstaan van klachten in de zin van dreigende huidperforatie, zal inkorten van de fibula gelukkig geen nadelige gevolgen hebben voor de totale lengte van de onderbeenstomp.

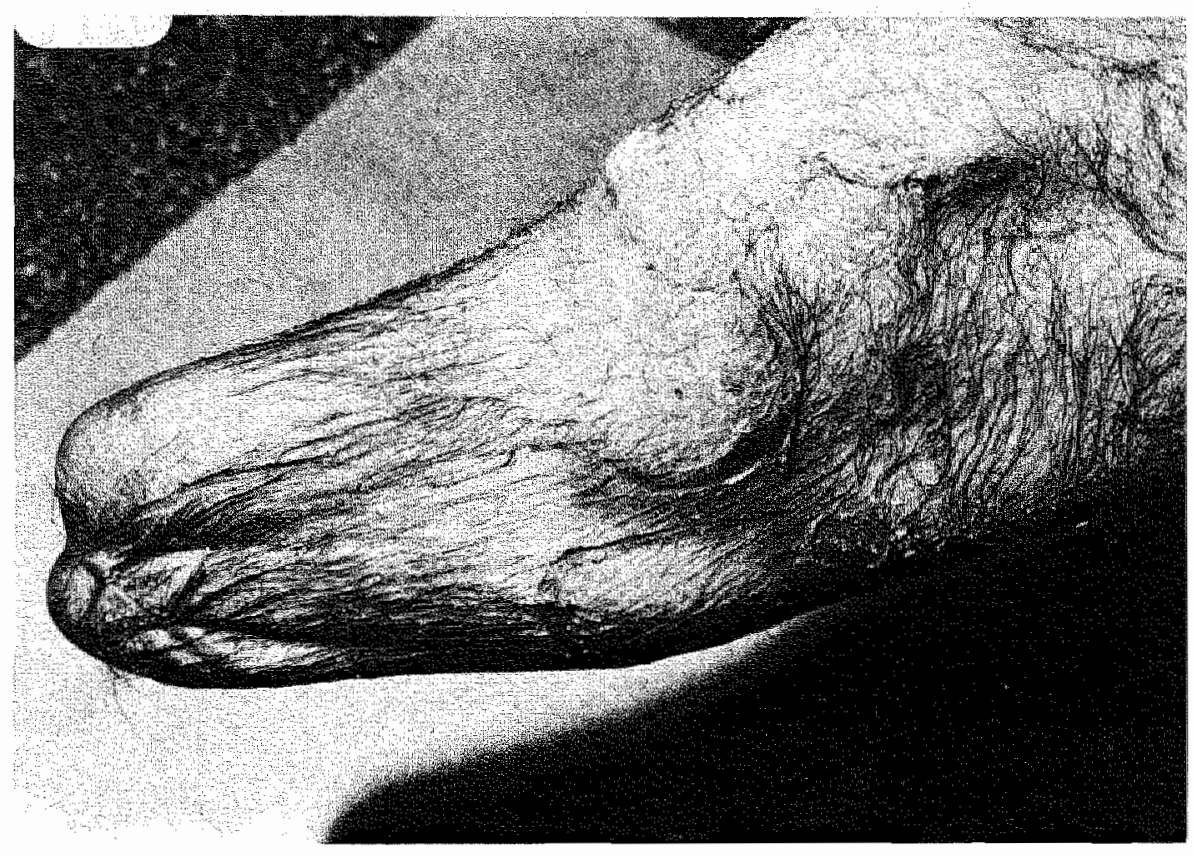

Fig. 19: Promineren var de weke delen ter plaatse van de fibulastomp.

In de hoofdstukken VI en VII zullen separaat de exarticulatie volgens Syme en de knie-exarticulatie behandeld worden. Deze zijn zo belangrijk, ook voor de jeugdige patiënt, dat zij deze aparte beschrijving ten volle verdienen. 
In het mens-machine-milieu systeem werd met opzet tot nu toe nauwelijks gesproken over de machinefactor, de prothese. De mens in interactie met zijn milieu levert bij de bovengenoemde en behandelde categorieën steeds specifieke problemen op. Doel van dit hoofdstuk was aandacht te vragen voor deze problemen.

De mens, de patiënt, de revalidant hebben recht op een juiste benadering door respectievelijk psycholoog, chirurg en revalidatie-arts. Het willen ingaan op de problemen en het zoeken naar een oplossing samen met de fysiotherapeut, de maatschappelijk werkende, de ergotherapeut en de verpleegkundige maakt het werk van de prothesemaker alleen maar gemakkelijker. De koppeling mens-machine tot een functionele eenheid te maken kan realiteit worden, zonder dat alle facetten van deze eenheid volledig begrepen worden.

Dat is dan het resultaat van het werk, verricht door een team, dat slechts één doel voor ogen mag staan. Een doel dat in het volgende gedicht verwoord wordt:

\author{
, Was ist Theorie? \\ Wenn's klappen soll und klappt doch nie \\ Was ist Praxis? Mensch frag doch nie \\ so dumm \\ Wenn's klappt \\ und keiner weiß warum!"'
}




\section{Eigen onderzoek.}

"Few if any areas of major surgery present the challenge currently offered by amputations". Burgess

In de periode van Juni 1972 tot Juni 1977 werden in het R.C.H. 125 patiënten opgenomen voor eerste prothesevoorziening en revalidatie, nadat in een algemeen ziekenhuis één of meer beenamputaties waren verricht.

Bij deze 125 patiënten werden in totaal 143 amputaties uitgevoerd op verschillende niveaus van de onderste extremiteit.

\section{1 Herkomst van de onderzoekspopulatie.}

De herkomst van de in dit onderzoek betrokken patiënten is weergegeven in fig. 20, verdeeld naar de aard van de chirurgische ingreep vóór revalidatie.

HE: Heupexarticulatie

DBB: Dubbele Bovenbeenampuratie

$B B$ : Bovenbeenamputatie

$B B+O B *$ Bovenbeen-en Onderbeenamputatie

KE: Knie-exarticulatie

$D O B$ : Dubbele Onderbeenampatatie

$O B$ : Onderbeenamputatie

Syme: Syme-exarticulatie.

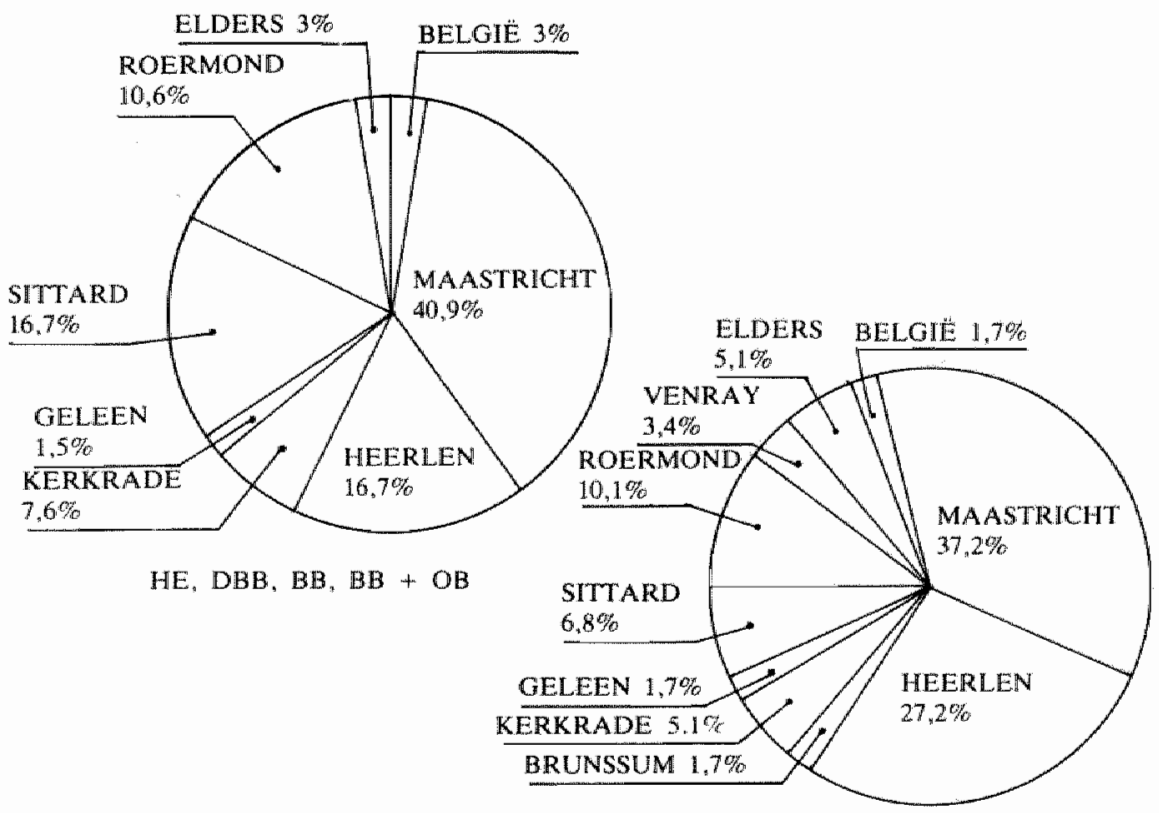

Fig. 20: Herkomst van de patiënten.

KE, DOB, OB, SYME 
Zoals te verwachten is, kwamen deze patiënten vrijwel allen uit de ziekenhuizen van dle regio Zuid- en Midden-Limburg en werden rechtstreeks vanuit het ziekenhuis in het revalidatiecentrum opgenomen. Slechts enkele revalidanten werden na ontslag uit het ziekenhuis verwezen door de huisarts. (zie fig. 21).

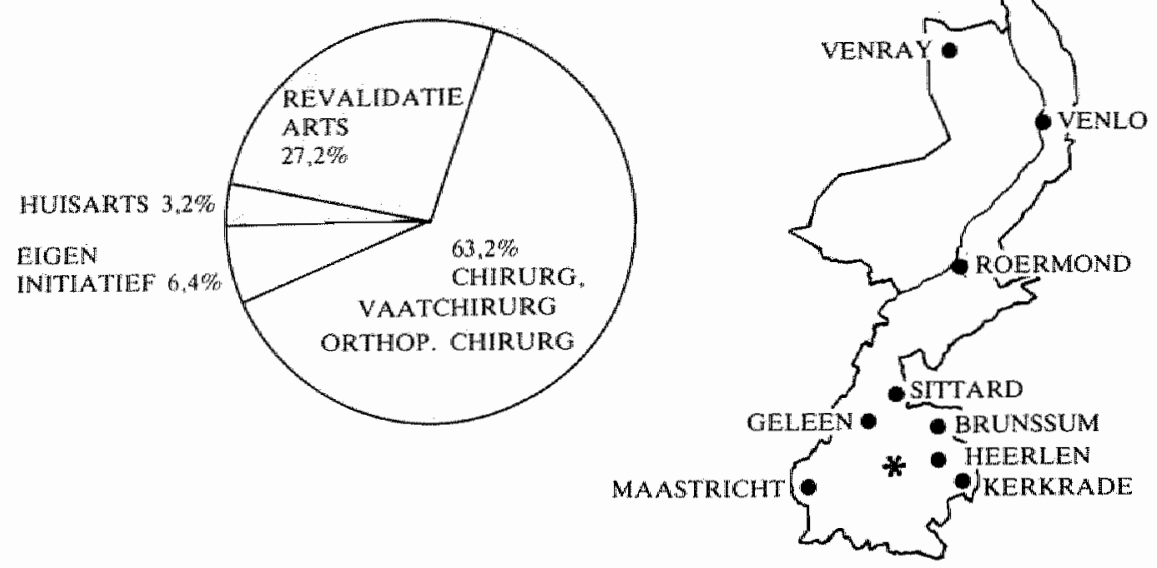

PROVINCIE LIMBURG

* hoensbroek

Fig. 21: Verwijzer naar Rev. Centrum HOENSBROECK.

Van de bovenbeengeamputeerden kwam $40.9 \%$ uit het ziekenhuis van Maastricht. Voor de ziekenhuizen van Heerlen en Kerkrade waren deze getallen respectievelijk $16.7 \%$ en $7.6 \% .28 .8 \%$ van de bovenbeengeamputeerden kwam uit het gebied dat noordelijk van Hoensbroek is gelegen (Sittard, Geleen en Roermond).

Tenslotte werden enkele patiënten uit België $(3 \%)$ en elders uit Nederland (3\%) naar het R.C.H. verwezen.

Voor de onderbeengeamputeerden is de herkomst anders verdeeld.

$\begin{array}{lrl}\text { Maastricht } & 37.2 \% & \text { (B.B. 40.9\%) } \\ \text { Heerlen } & 27.2 \% & \text { (B.B. 16.7\%) } \\ \text { Sittard } & 6.8 \% & \text { (B.B. 16.7\%) } \\ \text { Roermond } & 10.1 \% & \text { (B.B. 10.6\%) }\end{array}$

Het opvallende verschil tussen de ziekenhuizen van Maastricht en Heerlen, waarbij in Heerlen procentueel meer onderbeenamputaties verricht werden, zou erop kunnen wijzen dat het amputatieniveau aldaar door grote terughoudendheid onder het niveau van het kniegewricht kon worden gehouden.

Over de jaren $1972 \mathrm{t} / \mathrm{m} 1976$ werd de frequentieverdeling nagegaan van boven- en onderbeenamputaties, op beide chirurgische afdelingen verricht, bij naar het R.C.H. ter revalidatie verwezen patiënten, welke deel uitmaken van dit onderzoek. 

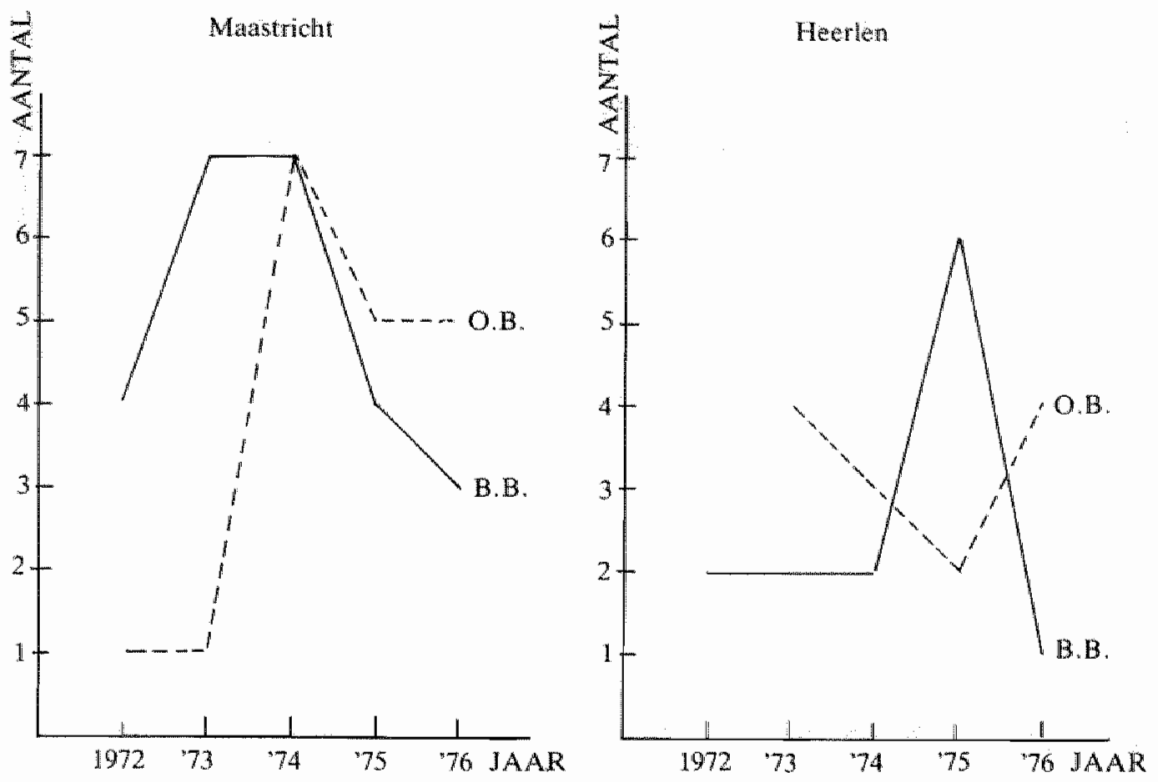

Grafiek 1: Onderlinge werhouding wan boven-en onderbechgeamputerden, afkomstig wit de ziekenhutzen Mastricin en Herlen.

Grafiek 1 laat zien hoe in de jaren 1972, 1973 en 1974 nog veel bovenbeenamputaties werden verricht in Maastricht. Vanaf 1974 heeft het onderbeenniveau duidelijk de overhand.

De cijfers met betrekking tot boven- en onderbeenniveau voor het ziekenhuis te Heerlen laten dit verschil zeker niet zien. De suggestie dat op grond van deze cijfers in Maastricht vaker op onderbeenniveau wordt geamputeerd, is echter ook voorbarig. Daarvoor is het totale aantal amputaties te gering terwijl meerdere factoren ten deze ook invloed kunnen hebben zoals:

- een verschil in primaire verwijzing naar de beide heelkundige afdelingen;

- een verschil in secundaire verwijzing van deze beide afdelingen naar het R.C.H. versus andere centra voor revalidatie;

- de frequentie van diabetes mellitus in de onderzochte groepen;

- de uitgebreidheid van een aan de amputatie voorafgegane vasoreconstructieve ingreep;

- de tijd verlopen tussen een aanvankelijk succesvolle reconstructie en het moment van amputatie;

- een stenosering, die snell dan wel langzaam optreedt;

- de conditie van de patiënt, die, gezien de narcoseduur, geen vaatoperatie toelaat, maar wel amputatie op onderbeenniveau;

- het binnen een patiëntengroep meer voorkomen van traumata en tumoren, welke mogelijk tot bovenbeenamputatie aanleiding geven.

Het onderzoek naar deze factoren is niet uitgevoerd, omdat het totaal aantal patiënten van Maastricht en Heerlen in deze jaren te gering is om er conclusies aan te verbinden. Bovendien staat in deze studie de revalidatieproblematiek centraal en niet die van de chirurgische indicatiestelling ten aanzien van de betreffende aandoeningen van de onderste extremiteiten. 
De verdeling naar soorten verwijzers naar het R.C.H. is weergegeven in fig. 21, annex het geografisch overzicht van de ziekenhuizen in Limburg van waaruit de patiènten verwezen werden.

Uit fig. 21 blijkt dat de patienten voornamelijk verwezen werden door de algemeen chirurgen en orthopedisch chirurgen $(63.2 \%)$ met daarnaast revalidatie-artsen $(27.2 \%)$.

Met "eigen initiatief" wordt bedoeld de patiënt, die op eigen initiatief naar het revalidatiecentrum kwam, waarna de huisarts door ons hiervan in kennis werd gesteld.

De geografische centrale ligging van het R.C.H. t.o.v. de algemene ziekenhuizen van de regio moge ten overvloede uit fig. 21 blijken.

\section{2 Indicatie tot amputatie.}

In verband met de betekenis welke aan de bevindingen van dit onderzoek zijn toe te kennen, werd getracht meer inzicht te krijgen in de representativiteit van de onderzoekspopulatie wat amputatieindicaties in het algemeen betreft. Daartoe werden deze indicaties van de onderhavige onderzoeksgroep vergeleken met de voorhanden nationale en internationale gegevens dienaangaande.

\begin{tabular}{lrrr} 
& Mannen & Vrouwen & \multicolumn{1}{l}{ Totaal } \\
\cline { 1 - 4 } \cline { 5 - 5 } Vasculaire complicaties bij: & & & \\
- Arteriosclerosis & $45(36,0 \%)$ & $7(5,6 \%)$ & $100(80 \%)$ \\
- Diabetes mellitus & $18(14,4 \%)$ & $30(24,0 \%)$ & \\
\hline Trauma & $9(7,2 \%)$ & $4(3,2 \%)$ & $13(10,4 \%)$ \\
Maligniteit & $5(4,0 \%)$ & $4(3,2 \%)$ & $9(7,2 \%)$ \\
Osteomyelitis & $2(1,6 \%)$ & & $2(1,6 \%)$ \\
Lepra & $1(0,8 \%)$ & $1(0,8 \%)$ \\
Totaal & $80(64,0 \%)$ & $45(36,0 \%)$ & $125(100 \%)$ \\
\hline
\end{tabular}

Tabel 4: Indicarie rot ampatatie bij 125 patiënten.

Tabel 4 laat zien dat bij 100 patiënten een vaatlijden, al of niet gecompliceerd door het bestaan van diabetes mellitus, aanleiding was tot amputatie. Hierbij valt op dat de perifere vasculaire complicaties ten gevolge van diabetes mellitus meer bij vrouwen voorkwamen. Daarentegen werd bij 45 mannen een amputatie verricht wegens complicaties ten gevolge van een perifeer vaatlijden alleen; slechts 7 vrouwen werden om deze reden geamputeerd.

Dat deze 125 patiënten representatief zijn wat betreft de amputatie-indicatie lijkt meer dan waarschijnlijk. Nederlandse cijfers kunnen ontleend worden aan een onderzoek van Bakker (1973).

" Van het aantal amputaties voor geheel Nederland in 1969 werd een betrouwbare indruk verkregen d.m.v. gegevens van de S.M.R. (Stichting Medi- 
sche Registratie) te Utrecht. Deze stichting verzamelde in 1969 gegevens van 614.778 in Nederlandse ziekenhuizen opgenomen patiènten. Deze 614.778 opgenomen patiënten vormden drie-vijfde deel van de totale Nederlandse ziekenhuispopulatie in 1969. De spreiding van de - aan de stichting deelnemende - ziekenhuizen was zodanig, dat vermenigvuldiging met de factor vijf-derde een betrouwbare indruk geeft over de voor geheel Nederland geldende getallen" (Bakker 1973).

Aan Bakker worden de volgende cijfers ontleend:

Amputatie onderste extremiteit: 645 .

Arteriële doorbloedingsstoornissen:

Traumatische amputaties:

$485 \quad 75.19 \%$

Maligne tumoren:

$73 \quad 11.31 \%$

Infectie:

$31 \quad 4.80 \%$

Andere oorzaken:

$19 \quad 2.94 \%$

$37 \quad 5.73 \%$

Gecorrigeerd voor Nederland met de factor vijf-derde:

Arteriële doorbloedingsstoornissen

$808 \quad 75.37 \%$

Traumatische amputaties:

$121 \quad 11.28 \%$

Maligne tumoren:

$51 \quad 4.75 \%$

Infectie:

$31 \quad 2.89 \%$

Andere oorzaken:

$61 \quad 5.69 \%$

$99.98 \%$

Gezien de volgende meer recente cijfers blijkt het percentage op vasculaire basis geamputeerden sterk te zijn toegenomen.

Zo vermeldt een zorgvuldig Zweeds onderzoek in 1973 een als representatief te beschouwen distributie van amputatie-oorzaken voor de onderste extremiteiten, welke alleen in tijden van oorlog en rampen een wijziging.zou kunnen ondergaan: (Commissie van de Europese Gemeenschappen 1973)

Arteriële doorbloedingsstoornissen:

$85 \%$

Traumatische amputaties:

Tumoren: $4 \%$

Gemengde groep (osteomyelitis, misvormingen van de ledematen etc.):

De National Health Service in Engeland meldt dat in $196884 \%$ van de amputaties het gevolg was van een vaatziekte. (Commissie van de Europese Gemeenschappen. 1973).

Over 1972 - 1977, de periode waarover dit onderzoek in het R.C.H. werd verricht, werd door v.d Tempel (1978) te Groningen een onderzoek gedaan waarbij de volgende indicaties tot amputatie werden gesteld:

Vaatlijden:

$80 \%$

Trauma:

$10 \%$

Oncologische processen:

Chronische infecties:

$10 \%$

Congenitale afwijkingen: 


\section{3 Verdeling naar amputatieniveau.}

\begin{tabular}{lllllll}
\hline & HE & BB & KE & OB & Syme & Totaal \\
Primair amputatieniveau & 2 & 52 & 1 & 84 & 4 & 143 \\
Secundair amputatieniveau & 2 & 66 & 2 & 72 & 1 & 143 \\
\hline
\end{tabular}

HE: Heupexarriculatie.

BB: Bovenbeenamputatie.

KE: Knie-exarticulatie.

$O B$ : Onderbeenamputatie.

Tabel 5: Verdeling naar amputatieniveau.

Bij 125 patiënten werden in totaal 143 amputaties verricht, zoals in tabel 5 wordt weergegeven. Hierbij dient opgemerkt te worden dat van de 4 exarticulaties volgens Syme slechts één patiënt niet gereamputeerd hoefde te worden. $\mathrm{Bij}$ de 3 resterende exarticulaties volgens Syme was tweemaal een reamputatie nodig op onderbeenniveau. Eénmaal waren twee reamputaties nodig; eerst een onderbeen-, daarna een bovenbeenamputatie. Van de in totaal 84 patiënten met aanvankelijk een onderbeenamputatie moesten 14 patiënten gereamputeerd worden. 13 maal op bovenbeenniveau; éénmaal was een knie-exarticulatie noodzakelijk.

Bij 17 patiënten moesten dus in totaal 18 reamputaties verricht worden $(14,4 \%)$. Eénmaal was er sprake van een recidief bij een maligne tumor; tweemaal was de insufficiënte circulatie, gecombineerd met diabetes mellitus, reden tot hernieuwd ingrijpen.

Tenslotte was in 14 gevallen sprake van storing in de wondgenezing zonder dat diabetes mellitus hierbij een rol speelde. Het interval tussen de primaire amputatie en de reamputatie tot het definitieve amputatieniveau varieerde in sterke mate. (van minder dan I maand tot ruim 1 jaar).

\begin{tabular}{lcccc} 
& & \multicolumn{2}{l}{ Aantal Revalidanten } \\
\cline { 2 - 5 } "definitief' Amputatieniveau. & Links & Rechts & Dubbelz. & Totaal \\
\hline HE. & 1 & 1 & - & 2 \\
\hline BB. & 33 & 22 & 3 & 58 \\
\hline BB en OB & - & - & 5 & 5 \\
\hline KE & 1 & - & - & 1 \\
\hline KE en OB & - & - & 1 & 1 \\
\hline OB & 18 & 30 & 9 & 57 \\
\hline Syme & - & 1 & - & 1 \\
\hline Totaal & 53 & 54 & 18 & 125 \\
\hline
\end{tabular}

Tabel 6: Amputatieniveau en aantal revalidanten.

Tabel 6 laat het secundaire of wel het definirieve amputatieniveau zien, waarbij opvalt dat in de onderzochte groep 18 patiënten met een dubbelzijdige amputatie voor revalidatie werden aangeboden $(14,4 \%)$. 


\section{4 Amputatieleeftijd onderverdeeld naar geslacht en amputatieniveau.}

\begin{tabular}{lrlcl}
\hline $\begin{array}{l}\text { Gem. amp. leeftijd } \\
\text { in jaren. }\end{array}$ & Mannen & Amputatieniveau & \multicolumn{2}{c}{$\begin{array}{c}\text { Vrouwen Gem. amp. leeftijd } \\
\text { in jaren. }\end{array}$} \\
\hline 19 & 1 & HE & 1 & 57 \\
53,6 & 43 & KE en BB & 16 & 55,2 \\
58 & 4 & BB met OB & 2 & 68 \\
58,8 & 31 & KE met OB & 26 & 69,4 \\
45 & $\mathbb{O B}$ & Syme & - & - \\
\hline 46,9 & 80 & Totaal & 45 & 62,4 \\
\hline
\end{tabular}

Tabel 7: Gemiddelde amputatieleeftijd en verdeling in mannelijke en vrouwelijke revalidanten naar amputatieniveau.

In tabel 7 wordt de gemiddelde amputatieleeftijd, verdeeld naar geslacht en amputatieniveau, meer gedetailleerd weergegeven. Er wordt geen speciale vermelding meer gemaakt van de drie dubbelzijdige bovenbeenamputaties en de negen dubbelzijdige onderbeenamputaties. Deze zijn ondergebracht bij de boven- en onderbeenamputaties.

De amputatieleeftijd is de leeftijd van de revalidant op het tijdstip van de "definitieve amputatie". Deze is voor de onderzochte groep gemiddeld 54.6 jaar, waarbij een verschil bestaat tussen de gemiddelde amputatieleeftijd voor mannen ( 46.9 jaar) en vrouwen (62.4 jaar).

De verhouding tussen mannen en vrouwen is ongeveer $2: 1$. Een verhouding, die overeenkomt met een recente publikatie uit de U.S.A. (Reyes 1977).

Opvallend is dat bij de mannen $60 \%$ van de amputaties in en boven het niveau van de knie plaats had, terwijl dit bij de vrouwen ruim $42 \%$ bedraagt. Mogelijk hangt dit ten dele samen met het in deze laatste groep meer voorkomen van diabetes mellitus. (vgl. tabel 4 ).

Een onderverdeling in leeftijdsgroepen naar amputatieniveau en opgesplitst in mannelijke en vrouwelijke patiënten wordt weergegeven in tabel 8 , waarbij de twee heupexarticulaties en de exarticulatie volgens Syme buiten beschouwing zijn gebleven, waardoor dus 122 patiënten voor verder onderzoek overblijven.

Van de 122 patiënten met een bovenbeen-, onderbeenamputatie of knie-exarticulatie zijn er slechts 24 die jonger zijn dan 50 jaar. Dit wil zeggen dat $80 \%$ ouder is dan 50 jaar en ruim $31 \%$ ouder dan 70 jaar. Bij de vrouwen blijkt de amputatieleeftijd aanmerkelijk hoger te liggen dan bij de mannen. Vooralleer aan dit gegeven conclusies kunnen worden verbonden zou op dit verschil 0 .a. de correctie qua verschil in bevolkingsopbouw tussen mannen en vrouwen dienen te worden aangebracht. 


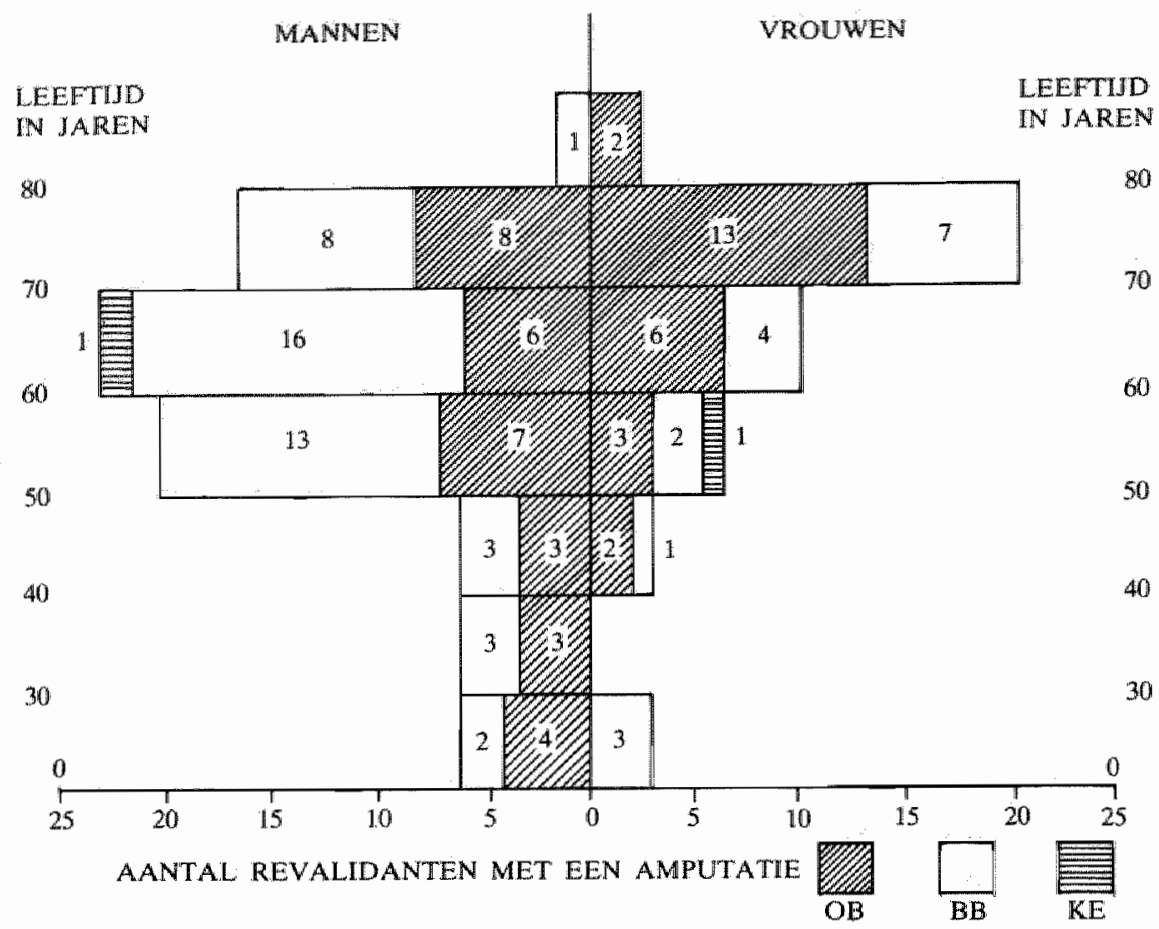

Tabel 8: Onderverdeling naar leeftijd en gestacht.

\section{5 Complicerende factoren.}

\begin{tabular}{lc}
\hline Stoornissen van & 11 \\
\hline Visus-Gehoor-Stem/Spraak & 28 \\
\hline $\begin{array}{l}\text { Bewegingsapparaat } \\
\text { Orthopaed./Neurologisch/Rheumatisch }\end{array}$ & \\
\hline $\begin{array}{l}\text { Physieke Belastbaarheid } \\
\text { Cardio-Pulmonale afwijkingen } \\
\text { Lever en Nierafwijkingen }\end{array}$ & 76 \\
\hline $\begin{array}{l}\text { Gedrag/Psychische functies } \\
\text { (Pseudo)dementie/Debilitas mentis }\end{array}$ & 16 \\
\hline
\end{tabular}

Tabel 9: Complicerende factoren.

Deze complicerende factoren hebben een belangrijke zo niet beslissende invloed op het revalidatieproces. Bij slechts 39 van de 122 patiënten was de amputatie de enige handicap. Voor alle andere patiënten waren beperkende factoren aanwezig, welke voor sommige van hen niet te overwinnen waren.

Uitgaande van de mens als sociaal wezen is het aannemelijk dat door blindheid, afasie of doofheid de contacten met de medemens in eerste instantie ernstiger verstoord raken dan door overige bovengenoemde complicaties. De combinatie van een zintuiglijke handicap en een beenamputatie vormt dan 
ook veelal een ernstige complicatie, ook ten aanzien wan de motivatie tot revalidatie c.q. looptraining, (zie tabel 9).

Het gemis aan visuele waarneming van de omringende wereld, die wel via geluidsperceptie aanwezig is, wordt, blijkens de ervaring opgedaan bij de onderzochte groep patiënten, minder ernstig ervaren dan de afwezigheid van geluidsperceptie bij een overigens normaal gezichtsvermogen. Het zich willen isoleren is typisch voor de gehoorgestoorde in tegenstelling tot de blinde mens. De visueel gehandicapte lijkt juist meer gemotiveerd na amputatie weer te willen leren lopen. Anders dan ziende mensen, ontvangt de blinde mens impulsen uit het hem omringende milieu, die hij node kan missen, zeker niet wanneer door een beenamputatie zijn actieradius verkleind wordt ten gevolge van een niet gelukken van revalidatie c.q. looptraining.

De neiging tot isolering, regelmatig te constateren bij dove mensen, wordt mogelijk bekrachtigd door de repercussies van een beenamputatie. De dove mens, niet verstoken van visuele waarneming, mist het sociale, intermenselijke contact dat juist via stem en spraak tot stand komt en dat, gegeven zijn doofheid, niet door grotere mobiliteit verbetert. Juist dit gemis aan typisch menselijk contact en de mogelijke frustratie, hierdoor opgeroepen, kan een verklaring zijn van de al of niet bewuste tendens tot zelfisolatie. Aldus raakt, althans in sociaal opzicht, een dove ernstiger gehandicapt dan een blinde mens.

De afatische mens, gestoord in hetzij.sensorische hetzij motorische, hetzij mnestische aspecten van het taalgebruik, kan eveneens ernstig lijden onder dit gemis aan mogelijkheden, waar begrip van en uiting in de menselijke taal in al zijn nuances hem zeer ontmenselijken. Het schrift, het geschreven woord wordt niet voor niets één van de grootste uitvindingen van de mens genoemd. Het niet meer kunnen begrijpen van het geschrevene, dat een tot onbegrijpelijke tekens gedegradeerd spijkerschrift is geworden of het niet meer kunnen reageren op alle emoties die schrift, stem of taal kunnen oproepen, ontnemen ook de afatieker de mogelijkheid mens met de mensen te zijn.

Nader onderzoek naar de ernst van een dubbele handicap, waarbij bovengenoemde zintuiglijke gebreken een rol spelen, en naar hun invloed op revalidatiemogelijkheden, is dringend gewenst.

\section{6 Tijdsduur tussen amputatie, opname in en ontslag uit het R.C.H.}

\begin{tabular}{l|c|c|c|c|}
\hline & \multicolumn{3}{c}{ O.B. } & \multicolumn{2}{c}{ B.B. } \\
\hline Tijdsduur in dagen & Conv. & I.F. & Conv. I.F. \\
\hline $\begin{array}{l}\text { tussen amputatie } \\
\text { en opname R.C.H. }\end{array}$ & 69 & 35 & 92 & 35 \\
\hline $\begin{array}{l}\text { tussen opname en ontslag R.C.H. } \\
\text { tussen amp. datum } \\
\text { en ontslag R.C.H. }\end{array}$ & 112 & 112 & 151 & 149 \\
\hline
\end{tabular}

Tabel 10: Vergelijking van tijdsperioden tussen amputatie, opname in en antslag wir R.C.H. voor:

- De groep "conventionele" revalidanten.

- De Immediate Fitting groep. 
De tijd, doorgebracht in het algemeen ziekenhuis vanaf het moment van de amputatie tot opname in het R.C.H. bedraagt woor de onderbeengeamputeerden gemiddeld 69 dagen, voor de bovenbeengeamputeerden gemiddeld 92 dagen.

Het verblinf in het R.C.H. was voor onderbeenprothesedragers gemiddeld 112 dagen en voor bovenbeenprothesedragers gemiddeld 151 dagen. (zie tabel $10)$.

In deze berekening is een groep patiènten opgenomen, waarbij de techniek van de "immediate fitting" werd toegepast. Bij deze groep patiënten werd direct postoperatief, en well na toepassing van myodese en/of myoplastische operatietechnieken, een gipssocket aangelegd bestaande uit een inwendige elastische- en een starre uitwendige gipskoker met van distaal naar proximaal afnemend drukverval.

Bij 19 patiënten is deze aanpak direct postoperatief overwogen, hetgeen betekende dat in deze gevallen vanaf of reeds vóór het moment van de amputatie contact bestond tussen de operateur, de patiënt en de "prosthetic surgeon'.

Bij 13 patiënten werd besloten deze "immediate fitting" toe te passen, waaronder 11 onderbeen- en 2 bovenbeenamputaties. De gemiddelde tijdsduur tussen amputatie, gevolgd door "immediate fitting" en opname in het R.C.H. bedroeg dan gemiddeld 35 dagen, tegenover 69 dagen bij onderbeengeamputeerden en 92 dagen bij bovenbeengeamputeerden, wanneer de behandeling op conventionele wijze had plaatsgevonden.

Karthaus (1973) vond bij een groep van 28 onderbeengeamputeerden, waarbij de immediate fitting procedure werd gevolgd, een gemiddelde tijdsduur van 5 maanden (150 dagen) tussen de operatiedatum en het verstrekken van de definitieve prothese. Ook hier bestond vanaf het moment van amputatie contact tussen de operateur en het revalidatieteam. Voor de 11 onderbeengeamputeerden uit dit rapport, waarbij immediate fitting werd toegepast, bedraagt dezelfde tijdsduur 147 dagen, terwijl dit voor de andere, conventionele groep onderbeengeamputeerden 181 dagen is.

Sarmiento (1970) heeft, evenals het amputatieteam van het R.C.H., de indruk, dat patiënten na een myodese en/of myoplastische amputatie, gevolgd door immediate fitting, niet beter functioneerden dan conventioneel behande]de patiënten, althans in eerste instantie.

Nogmaals dient met Molen e.a. benadrukt te worden de mening dat snel postoperatief mobiliseren (zelfs door sommigen op de eerste postoperatieve dag) als nadeel heeft dat het lopen met een onderbeenprothese ongeveer $20 \%$ meer arbeid (zuurstof) vereist, en bij een bovenbeengeamputeerde nog meer. (Molen e.a. 1973).

Gezien het feit dat bij atherosclerose het gehele vaatstelsel min of meer is aangetast en gezien de meestal geringe conditie van een bejaarde patiënt, na lange bedlegerigheid, is een snelle mobilisatie gecontraindiceerd.

Ofschoon het aanvankelijk bestaand enthousiasme voor de immediate fitting procedure langzaam gedaald is, niet alleen in Nederland, is het grote voordeel hiervan geweest de belangstelling welke van chirurgische zijde ontstaan is voor de patiënt, die een amputatie moet ondergaan. 


\section{7 Onderbeengeamputeerden.}

\begin{tabular}{lccccc}
\hline & \multicolumn{3}{c}{ Aantal revalidanten } & \\
\cline { 2 - 5 } "definitief" Amputatieniveau. & Links & Rechts & Dubbelz. & Totaal \\
\hline HE. & 1 & 1 & - & 2 \\
\hline BB. & 33 & 22 & 3 & 58 \\
\hline BB en OB & - & - & 5 & 5 \\
\hline KE & 1 & - & - & 1 \\
\hline KE en OB & - & - & 1 & 1 \\
\hline OB & 18 & 30 & 9 & 57 \\
\hline Syme & - & 1 & - & 1 \\
\hline Total & 53 & 54 & 18 & 125 \\
\hline
\end{tabular}

Tabel 6: Amputatieniveau en aantal revalidanten.

Volgens tabel 6 werden bij 63 patiënten in totaal 72 onderbeenamputaties verricht. Bij deze 63 patiënten waren 9 dubbelzijdige onderbeenamputaties. Bij 6 personen werd enerzijds een onderbeenamputatie verricht en anderzijds een bovenbeenamputatie of knieexarticulatie. Bij 48 patiënten is een éenzijdige onderbeenamputatie uitgevoerd.

Operatietechniek.

\begin{tabular}{lrrl}
\hline Indicatie tot amputatie & Conventioneel & Myodese/Myoplast. Onbek. \\
\hline Vasc. insuff. t.g.v. & & 9 & 4 \\
Atherosclerose. & 14 & & \\
Vasc. insuff. t.g.v. & & 16 & 2 \\
Diabetes mellitus & 13 & 2 & 2 \\
Trauma & 7 & 1 & - \\
Maligniteit & - & 1 & - \\
Lepra & 1 & 29 & 8 \\
\hline Totaal & 35 & 29 & \\
\hline
\end{tabular}

Tabel 11: Operatietechniek bij onderbeenamputatie ingedeeld naar indicatie.

Uit tabel 11 blijkt dat bij 29 van de 72 onderbeenamputaties een myodese en/of myoplastiek werd toegepast (40.2\%).

De lengte van de amputatiestomp, gemeten vanaf de mediale gewrichtsspleet van de knie, valt bij $75 \%$ binnen de voorkeurslengte van 10 tot $16 \mathrm{~cm}$. Als ideale stomplengte kan 14 tot $16 \mathrm{~cm}$ worden aangegeven. Bij $20.8 \%$ is de amputatiestomp langer dan $16 \mathrm{~cm}$. en bij $4.2 \%$ korter dan $10 \mathrm{~cm}$.

Naast de vorm van de amputatiestomp en de conditie van de stompmusculatuur is ook de lengte belangrijk.

Gemeten vanaf de mediale gewrichtsspleet van de knie is een stomplengte van minder dan $10 \mathrm{~cm}$. met betrekking tot het bedienen van een prothese minder functioneel. Een te grote lengte van de amputatiestomp schept het 
risico van circulatiestoornissen in het stompuiteinde. Immers, in het distale derde deel van het onderbeen bevindt zich de overgang van de musculus triceps surae en de peroneaal musculatuur in hun respectievelijke peesbladen. De vascularisatie is hier minder toereikend, zodat op den duur ter plaatse stompproblemen kunnen onststaan.

\section{Ter illustratie 2 voorbeelden.}

A. In oktober 1973 werd in het R.C.H. opgenomen een 51 -jarige psychisch gestoorde wrouw. In juni van hetzelfde jaar was zij in het algemeen ziekenhuis opgenomen na een suicide poging. Ondermeer waren hiervan het gevolg fracturen van de $5 \mathrm{e}, 6 \mathrm{e}, 7 \mathrm{e}$, en 8 ste rib rechts lateraal, een haematothorax, fracturen van de 3 de, 4 de en 7 de thoracale wervel alsmede een ernstige compressiefractuur van lumbale III.

Tenslotte had zij gecompliceerde, communitieve en distaal gelocaliseerde onderbeen- en enkelfracturen beiderzijds. Er ontstond een massale infectie in beide fracturae cruris en in juni 1973 werd amputatie verricht op fractuurniveau.

Bij opname in het R.C.H. zagen wij een angstige vrouw. Het algemeen intern onderzoek liet behalve het bovenvermelde, geen duidelijke pathologie zien.

Status localis: aan de rechter zijde is het onderbeen geamputeerd $24 \mathrm{~cm}$ vanaf de mediale gewrichtsspleet der knie. Het litteken is eindstandig, terwijl de weke delen bedekking niet optimaal is. Het geheel is bij palpatie licht gevoelig. Aan de linker zijde is het amputatieniveau gelegen op $23 \mathrm{~cm}$. vanaf de gewrichtsspleet der knie, met dezelfde kwaliteiten als rechts.

Gezien de anamnese werden inlichtingen gevraagd aan de psychiater door wie de patiënte sinds 1970 behandeld werd i.v.m. een involutie depressie. Op grond van zijn inlichtingen werd aanvankelijk gedacht dat de vrouw naar alle waarschijnlijkheid geen prothesekandidate zou zijn. Desondanks werd begonnen met conditietraining. Dank zij de aandacht en de goede zorg van de verpleegkundigen knapte de patiënte, die aanvankelijk depressief en onrustig was, toch langzaam op.

Begin december 1973 leek zij toch well enigszins gemotiveerd voor prothesevoorziening en looptraining.

De psychische labiliteit heeft haar echter gedurende de gehele opname parten gespeeld. Zo reageerde zij met een heftige depressie, toen medio januari 1974 een zwelling optrad aan het rechter stompuiteinde. Ofschoon er geen sprake was van sequestrering en de oorzaak lag in een geînfecteerde hechting, vreesde patiënte dat zij aan bovenbeenamputatie niet kon ontkomen; een depressieve reactie was het gevolg. Door het begeleidend oedeem waren er moeilijkheden met de pasvorm van de prothese. Uiteindelijk liep patiënte medio maart 1974 met krukken.

Op dat moment was de P.T.B.-prothese (P.T.B.: Patella Tendon Bearing) beiderzijds nog in de pas.

Door het optreden van atrofie en het verdwijnen van het aanwankelijke oedeem in de beide onderbeenstompen, traden opnieuw pasvormproblemen op met de bovenvermelde labiele reacties op psychisch niveau. Ondanks al deze problemen kwam zij tot redelijk lopen met 2 stokken. Nu pas kon met haar overleg gepleegd worden omtrent de wenselijkheid tot amputatie op een hoger nivefu over te gaan. De circulatie in de beide stompuiteinden, d.w.z. in het derde distale deel van de tibia, liet nog steeds te wensen over en in overleg met de eerst behandelende chirurg werd besloten te reamputeren op een idealer niveau. Dit was pas mogelijk na een langdurig en moeizaam overleg met de patiënte, bemoeilijkt door haar psychisch labiel functioneren. Na deze dubbelzijdige reamputatie op hoger niveau hebben zich geen stompklachten meer voorgedaan en nog steeds loopt patiënte al of niet met loophulpen, afhankelijk van de terreinsituatie.

B. De volgende casus handelt over een vrouw geboren in 1917. In 1944 werd zij op 28-jarige leeftijd het slachtoffer van een bombardement bij het verlaten van een kerk, waar n.b. een dankdienst was gehouden voor het overleven van het oorlogsgeweld. $Z_{i j}$ liep hierbij een bilaterale traumatische onderbeenamputatie op.

In deze na-oorlogse tijd kreeg zij aanvankelijk een prothese van gips en leerde lopen zonder hulpmiddelen. In 1947 volgde de eerste aluminium prothese. In 195 I werd haar een prothesestel van leer verstrekt en ook hiermede kwam zij tot zelfstandig lopen.

In 1969 werd op de orthopedische werkplaats van het Revalidatiecentrum te Hoensbroek voor 
haar linker been een P.T.B.-prothese gemaakt, aan de rechter zijde werd zij voorzich van een conventionele prothese.

Bij het klimmen der jaren had zij de laatste tijd wat meer klachten betreffende hast algehele conditie gekregen, waarwoor zij behandeld werd door de internist. Deze klachten konden ten dele verklaard wordien door het bestaan van adipositas en hypertensie. Naast deze algemene klachten had zij regelmatig last van beide amputatiestompen.

In overleg met de revalidatie-arts en de internist werd besloten tot opname in het revalidatiecentrum i.v.m. een algehele revisie, hetgeen in februari 1977 plaats vond.

De tractus anamnese vermeldde geen andere afwajkingen dan bovengenoemdle.

Status localis: beiderzijds een onderbeenamputatie. Het linker bovenbeen heeft een wat grotere omvang dan rechts met een duidelijke varicosis.

Het rechter onderbeen is op $33 \mathrm{~cm}$.-, het linker onderbeen op $36 \mathrm{~cm}$. geamputeerd, gemeten vanaf de mediale gewricht sspleet der knie.

De beide uiteinden wan de amputatiestompen laten een weke delen slurf zien.

Behandeling en beloop; er werd voor de patiënte een uitgebreid fysiotherapeutisch oefenprogramma opgezet met het doel de energie-output te vergroten, zodanig dat, naast her dieet van $1400 \mathrm{cal}$, een vermagering zou optreden. Het gevolg hiervan was dat de patiënte, overigens begeleid door de internist, per week $1 \mathrm{~kg}$. in gewicht afnam. Bij opname bedroeg het lichaamsgewicht $98 \mathrm{~kg}$., bij ontslag $87 \mathrm{~kg}$. Door deze vermagering moesten de prothesen gereviseerd worden.

De wrouw, die zich een lange reeks van jaren nooit invalide gevoeld had, had de laatste jaren neiging tot depressies. De vicieuse cirkel, - minder lichamelijke conditie door ouder worden met als gevolg meer afhankelijk van anderen -, hadden wij voorlopig kunnen doorbreken. Poliklinisch vond daarna contrôle plaats.

Tijdens deze poliklinische contrôle bleek dat regelmatig klachten optraden van de rechter amputatiestomp. Het stompuiteinde was intermitterend rood, pijnlijk en gezwollen. De wekedelen-muts voelde koud aan en het weefsel was gindureerd.

In diverse gesprekken werd de wenselijkheid tot reamputatie overwogen. Ook bij deze patiente was het moeilijk haar ervan te overtuigen dat reamputatie op een juist niveau de enige oplossing voor haar problemen zou kunnen zijn. Uiteindelijk stemde zij hierin toe en in februari 1978 vond deze reamputatie rechts plats op $16 \mathrm{~cm}$. vanaf de mediale gewrichtsspleet, gevolgd door een myodese en een myofasciale plastiek.

De uitslag van het pathologisch anatomisch onderzoek luidde: reamputatiepreparaat met een uitgesproken vervetting van spierweefsel met atrofie.

Het postoperatieve verllow werliep geheel ongestoord.

In maart 1978 werd zij overgeplaatst naar het revalidatiecentrum. Gezien de veranderingen in de contouren van de amputatiestomp werd een nieuwe conventionele onderbeenprothese noodzakelijk; hierna kwam zij weer snell tot hetzelfde looppatroon, d.w.z. zelfstandig lopend of buiten eventueel gebruik makend van een stok. De patiënte gaf desgevraagd aan dat haar rechter amputatiestomp volledig pijnvrij was en dat zij bijoptreden van dezelfde klachten aan de linker zijde onmiddellijk tot reamputatie op idealer niveau wilde overgaan.

Volgens Bär (1957) dient men, wanneer "an der Stelle der Not" geamputeerd is, de definitieve amputatie "an der Stelle der Wahl." niet te lang wit te stellen. Men moet de patiënt vóor of ná de noodamputatie inlichten over de mogelijkheid, dat later eventueel een reamputatie noodzakelijk kan zijn. Bär (1957) signaleert, dat "in de praktijk is gebleken, dat patiënten een definitieve amputatie of "'trimming" weigeren als men dit lange tijd na een noodamputatie voorstelt." .

Het mogelijk ontstaan van circulatiestoringen bij amputatie in het distale derde deel van het onderbeen wijt de patiènt dan aan zijn prothese en het verwijt treft de prothesebouwer of het revallidatieteam.

Dit voorlichten van de patiënt geldt ook wanneer men een amputatie bij vaatlijden wil proberen op onderbeenniveau, terwijl de kans op succes dubieus is. 


\section{8 Prothesekeuze bij de onderbeengeamputeerden.}

\begin{tabular}{lccccc}
\hline Prothese & Eenz. O.B. & Dubbelz. O.B. "Gemengd"' & Totaal. \\
\hline P.T.B. & 32 & 5 & 2 & 39 \\
\hline Conventioneel & 14 & 11 & 3 & 28 \\
\hline Sierprothese & 1 & - & - & 1 \\
\hline Geen prothese & 1 & 2 & 1 & 4 \\
\hline Totaal & 48 & 18 & 6 & 72 \\
\hline
\end{tabular}

Tabel 12: Definitieve protheseopbouw bij:

48 eenz onderbeenamputaties.

9 dubbelz. onderbeenamputaties.

6 "gemengde" beenamputaties.

Tabel 12 geeft aan welke prothese uiteindelijk is gekozen voor de 48 éenzijdig onderbeengeamputeerden, voor de 9 dubbelzijdig geamputeerden en voor de 6 patiënten met een onderbeenamputatie enerzijds en een bovenbeenamputatie of knie-exarticulatie anderzijds.

32 patiënten met een éénzijdige onderbeenamputatie werden gemobiliseerd met een P.T.B.-prothese (P.T.B.: Patella Tendon Bearing), terwijl 14 patiënten voorzien werden van een conventionele prothese. Bij de dubbelzijdig onderbeengeamputeerden is bij de in totaal 9 patiënten $11 \mathrm{x}$ een conventionele prothese gerealiseerd, terwijl $5 x$ een P.T.B.-prothese werd gemaakt.

Bij éên patiënte van 79 jaar met een dubbelzijdige onderbeenamputatie is afgezien van prothesevoorziening wegens ernstige cardiale bezwaren.

Opgemerkt moet worden dat sinds juni 1977 bij het amputatieteam de neiging bestaat om dubbelzijdig onderbeengeamputeerden allen te voorzien van een conventionele prothese, ongeacht de leeftijd.

\begin{tabular}{|l|l|c|c|c|c|c|c|c|}
\hline \multicolumn{10}{|c|}{ Leeftijd in jaren. } \\
\hline Eenz. O.B. & $0-30$ & $30-40$ & $40-50$ & $50-60$ & $60-70$ & $70-80$ & $80-90$ \\
\hline P.T.B. & 2 & 2 & 3 & 4 & 7 & 12 & 2 \\
\hline Conventioneel & 1 & - & - & 3 & 4 & 6 & - \\
\hline Geen prothese & - & - & - & - & - & 2 & - \\
\hline Dubbelz. O.B. & \\
\hline P.T.B. & - & 1 & 2 & 2 & - & - & - \\
\hline Conventioneel & 2 & 1 & 2 & 4 & 2 & - & - \\
\hline Geen prothese & - & - & - & - & - & 2 & - \\
\hline "Gemengd" & & - & - & - & 2 & - & - & - \\
\hline P.T.B. & - & - & - & & & - \\
\hline Conventioneel & - & - & - & 3 & - & - & - \\
\hline Geen prothese & - & - & - & - & - & 1 & - \\
\hline
\end{tabular}


In tegenstelling hiermee is tabel 13, waarin nagegaan werd of er een verband bestaat tussen de aangemeten definitieve prothese en de leeftijd van de prothesedrager.

Voor de éénzijdige onderbeenamputatie kan gezegd worden dat de P.T.B.: prothese voor alle leeftijdsgroepen is gemaakt. De conventionele onderbeenprothese is op één uitzondering na - een jongen van 12 jaar - uitsluitend gebruikt bij patiënten ouder dan 50 jaar. Voor de dubbelzijdig onderbeengeamputeerden kan worden vermeld dat éénmaal een P.T.B.-prothese enerzijds en een conventionele prothese anderzijds is aangemeten. Overigens is steeds hetzelfde prothesetype beiderzijds toegepast.

Sinds juni 1977, nadat de laatste van de onderzochte groep van 125 patiënten van een prothese werd voorzien, zijn tot 1 januari 1979 inmiddels 75 patiënten gerevalideerd, aansluitend aan een beenamputatie elders. Bij deze 75 patiënten werd, vooropgesteld dat zij nog konden deelnemen aan het arbeidsproces steeds een onderbeengeamputeerde voorzien van een conventionele prothese. De P.T.B.-prothese blijft in het algemeen alleen gereserveerd voor de oudere patiënt, die, gezien zijn leeftijd of samenhangend met de aetiologie welke tot amputatie voerde, geen grote actieradius meer heeft.

De conventionele prothese, voorzien van een leren dijbeencorset, is primair bedoeld om de kniestabiliteit te helpen waarborgen. Bij de geringe actieradius van een oudere patiënt is deze bescherming tegen knie-instabiliteit niet nodig; het nauw sluitende dijbeencorset heeft bij een voornamelijk zittend leven alleen maar nadelen.

\section{V.9 Opnameduur ter revalidatie van onderbeengeamputeerden.}

\begin{tabular}{lll}
\hline Opnameduur in maanden. & Eenzijd. O.B.-amp. & Dubbelz. O.B.-amp. \\
\hline $0-1$ & $4(1 \times$ geen proth. $)$ & 1 \\
\hline $1-2$ & 4 & 1 (geen proth.) \\
\hline $2-3$ & 11 & - \\
\hline $3-4$ & $13(1 \times$ geen proth. $)$ & 1 \\
\hline $4-5$ & 6 & 1 \\
\hline $5-6$ & 5 & 1 \\
\hline $6-7$ & 3 & \\
\hline langer dan 7 mnd. & 2 & 4 \\
\hline
\end{tabular}

Tabel 14: Opnameduur van de onderbeengeamputeerden.

Voor de groep revalidanten met een éénzijdige (48) en met een dubbelzijdige (9) onderbeenamputatie werd de opnameduur in het R.C.H. nagegaan (tabel 14).

Over het algemeen wordt een revalidant pas ontslagen, wanneer de prothese "in de pas" is afgewerkt tot de definitieve prothese. (Prothese "in de pas" is de periode, waarin pasvorm en opbouw van de prothese worden nagegaan. Wanneer pasvorm en opbouw correct zijn bevonden, volgt de cosmetische afwerking van het geheel). 
De gerniddelde opnameduur voor deze 57 revalidanten bedroeg 112 dagen. Deze opnameduur werd overigens soms mede bepaald door het wachten op de meest noodzakelijke aanpassingen thuis, dan wel door de tijd welke nodig was; indien naar een nieuwe huisvesting gezocht moest worden.

De gemiddelde kosten van een dergelijke revalidatie bedroegen Fl. 35.000,-, uitgezonderd eventuele rolstoelvoorziening, huisaanpassingen, vervoersvoorzieningen etc.

\section{10 De resultaten van prothesevoorziening en looptraining.}

Het blijft moeilijk om de uiteindelijke resultaten van alle inspanningen van revalidanten en behandelteam te meten.

Natuurlijk ligt het woor de hand om het kunnen lopen met één of meer prothesen en eventueel een loophulp in de vorm van één of meer handstokken of elleboogkrukken als een bevredigende revalidatie te beschouwen.

Men kan stellen dat het doen van enkele stapjes binnenshuis reeds een belangrijk resultaat is. Zulks kan immers het verschil betekenen tussen plaatsing in een verpleegkliniek of bejaardenhuis.

Van een bevredigend looppatroon kan worden gesproken wanneer de prothesedrager in goede balans loopt met een gelijke staplengte, soepel hielcontact met de bodem en een goede voetafwikkeling. Dit is immers een looppatroon, waarbij het prothesebeen gelijk en dus maximaal belast wordt. Gezien de mogelijk aanwezige circulatiestoringen in het resterende been is dit een belangrijk aspect bij het realiseren van het revalidatieprogramma, waarop niet genoeg de nadruk gelegd kan worden.

Van belang is ook de revalidant zijn eigen tempo te laten bepalen. Chi-Tsou Huang (1977) e.a. stelt: "Persons with amputations work harder than unimpaired subjects though ambulating slowly". Molen (1973) e.a. vermeldt dat er rekening moet worden gehouden met een zuurstofverbruik bij éênzijdige onderbeenprothesedragers dat $20 \%$ hoger ligt dan bij valide personen. Hij wijst erop dat het opnieuw verwerven van een redelijke loopfunctie gepaard dient te gaan met grote aandacht voor het verbeteren van de algemene conditie. Deze aandacht voor de conditieverbetering wordt binnen het R.C.H. nauwlettend gevolgd en gestuurd door de functie-arts middels cardiotelemetrische contrôle.

De conclusie uit tabel 15 is dat van de 57 revalidanten met één- of dubbelzijdige onderbeenamputatie, 53 revalidanten het Revalidatiecentrum verlaten hebben, functionerend met hun prothese in de zin van het zich ermee verplaatsen met of zonder hulpmiddel in een redelijk of fraai looppatroon.

Een korte beschrijving volgt nu van de 4 revalidanten, waarbij dit resultaat niet bereikt werd.

- Een vrouw van 79 jaar met een ernstige hypertensie en symptomen van cardiale ischaernie werd opgenomen met een dubbelzijdige onderbeenamputatie. Na 5 weken werd, in overleg met haar, besloten dat de noodzakelijk op te brengen energie bij gebruik van 2 prothesen een te groot risico zou inhouden. Zij werd rolstoelgebruikster. 


\begin{tabular}{|l|l|l|l|l|l|l|}
\hline Hulpmiddel & \multicolumn{5}{|c|}{ Loopresultaat } \\
\hline & \multicolumn{5}{|c|}{ Goed } \\
& O.B. O.B./O.B. O.B. O.B./O.B. O.B. O. O. O. \\
\hline Geen & 2 & & 9 & 4 & & \\
\hline 1 Handstok & 7 & 2 & 14 & & & \\
\hline 2 Handstokken & 3 & 1 & 2 & & & \\
\hline 1 Elleboogkruk & & & & & & \\
\hline 2 Elleboogkrukken & 7 & 1 & & & & \\
\hline Looprekje & 1 & & & & & \\
\hline Cosm. Prothese & & & & & 1 & \\
\hline Rolstoel & & & & & 2 & 1 \\
\hline Totaal & 20 & 4 & 25 & 4 & 3 & 1 \\
\hline
\end{tabular}

Tabel 15: Resultaten van looptraining en prothesevoorziening bij 48 eenzijdige en 9 dubbelzjjdige onderbeengeamputeerden.

- Een 72-jarige man met een flexiecontractuur in de linker knie bij een onderbeenamputatie links en een bloot liggende tibia in de amputatiestomp werd na 14 dagen opname, terugverwezen naar het ziekenhuis. Na bovenbeenamputatie werd hij rolstoelgebruiker.

- Bij een 71-jarige vrouw met hypertensie, slechte cardiale toestand en resten van een doorgemaakte poliomyelitis was een onderbeenamputatie rechts verricht op basis van diabetisch gangreen. Wegens meervoudige beperkingen werd afgezien van revalidatie. Zzij kreeg een cosmetische prothese en werd rolstoelgebruikster.

- Een 67-jarige vrouw met M. Parkinson, blindheid en een forse adipositas werd gedurende 7 maanden opgenomen ter revalidatie na een onderbeenamputatie links wegens vasculaire insufficiëntie bij diabetes mellitus. Zij kreeg een P.T.B.-prothese en verliet het R.C.H. als rolstoelgebruikster. Zij kon met persoonlijke hulp enkele pasjes maken.

\begin{tabular}{|c|c|c|c|}
\hline \multirow[t]{7}{*}{$100 \%$} & \multicolumn{2}{|c|}{ Gunstig resultaat Tabel volgens Vaucher } & Aantal \\
\hline & & 1. Bedlegerig & 1 \\
\hline & & 2. Rolstoel & 3 \\
\hline & \multirow{4}{*}{$92,2 \%$} & 3. Loopt met prothese thuis. & 9 \\
\hline & & 4. Lopen met 2 handstokken. & 6 \\
\hline & & 5. Lopen met 1 handstok. & 23 \\
\hline & & 6. Zelfstandig lopen. & 15 \\
\hline \multicolumn{2}{|l|}{0} & Totaal & 57 \\
\hline
\end{tabular}

Tabel 16: Loopresultaten van de groep onderbeengeamputeerden gemeten volgens de classificatie van Vaucher.

Tabel 16 laat de loopresultaten nogmaals zien, maar nu ingedeeld volgens de classificatie van Vaucher. Met "gunstig resultaat" wordt bedoeld een plaatsing ten aanzien van het bereikte loopresultaat in een der classificaties $3 \mathrm{t} / \mathrm{m} 6$ van Vaucher. Hierbij werd de categorie "lopen met elleboogkrukken, dan wel met looprekje "uit tabel 15 ingedeeld bij groep 3 van Vaucher: "lopen met prothese thuis". Dit is in wezen een slechtere waardering, immers de man uit Hoofdstuk IV maakt nog altijd een kleine wandeling bij mooi weer, ondanks het feit dat "magere Hein" meeloopt. 


\section{11 Bovenbeengeamputeerden.}

Bij 63 patiënten zijn 66 bovenbeenamputaties gedaan, waarvan 3 dubbelzijdig. Bij 5 patiënten is een bovenbeenamputatie enerzijds en een onderbeenamputatie anderzijds verricht. Bij 55 patiënten is een éénzijdige bovenbeenamputatie uitgevoerd. (zie tabel 6).

De toegepaste operatietechniek is in 60 gevallen conventioneel (90.9\%), in 5 gevallen is een myoplastiek gebruikt $(7.5 \%)$ en énmaal is myodese verricht (1.6\%).

Ook bij een bovenbeenamputatie gelden dezelfde voordelen voor de amputatiestomp, wanneer myodese en/of myoplastiek worden toegepast, zoals in Hoofdstuk II beschreven.

\begin{tabular}{lllll}
\hline $\begin{array}{l}\text { Lengte } \\
\text { Amputatiestomp }\end{array}$ & $3-11 \mathrm{~cm}$. & $12-15 \mathrm{~cm}$. & $16-24 \mathrm{~cm}$. & onbekend. \\
\hline Aantal & 24 & 23 & 15 & 4 \\
\hline
\end{tabular}

Tabel 17: Lengte amputatiestomp in cm. gemeten vanaf de mediale gewrichtsspleet van de knie.

Het amputatieniveau bij bovenbeenamputatie dient bij voorkeur $12-15 \mathrm{~cm}$. proximaal van de mediale kniegewrichtsspleet gekozen te worden. (Karthaus 1973).

Afgezien van een functionele amputatiestomp bij deze gegeven amputatieniveaus, wordt dit niveau mede bepaald door de ruimte welke nodig is voor het inbouwen van een prothesekniegewricht.

De stomplengte bij de 66 onderzochte bovenbeenamputaties varieerde van $3-24 \mathrm{~cm}$., gemeten vanaf de mediale kniegewrichtsspleet. Slechts $34.8 \%$ van de amputatiestompen viel binnen het aanbevolen amputatieniveau. (tabel 17).

\section{12 Prothesekeuze bij de bovenbeengeamputeerden.}

\begin{tabular}{lllll}
\hline Prothese & eenz. B.B. & dbz. B.B. & gemengd & Totaal \\
\hline Zuigprothese & 18 & - & 1 & 19 \\
\hline Conventionele Proth. & 33 & - & 3 & 36 \\
\hline Cosmetische Proth. & - & 2 & - & 2 \\
\hline Geen Prothese & 4 & 4 & 1 & 9 \\
\hline
\end{tabular}

Tabel 18: Definitieve protheseopbouw bij:

55 eenzidige bovenbeenamputaties.

3 dubbelzijdige bovenbeenamputaties.

5 "gemengde" dubbelz. amputaties.

De mogelijkheden voor prothesevoorziening zijn in grote lijnen:

a. de zuigprothese met tuberzit. Hierbij is meestal, door het vacuummechanisme in het distale deel van de stompkoker, geen extra bevestiging aan het lichaam noodzakelijk. Dit werd in het R.C.H. wél toegepast bij een kritische stomplengte om middels een heupscharnier (R.P.B.: Rigid Pelvic Band) de neiging tot zwikken naar de prothesekant bij het belasten van het prothesebeen zoveel mogelijk tegen te gaan. 18 revali- 
danten met een éénzijdige bovenbeenamputatie (32.7\%) hebben een zuigprothese gekregen, waarvan het merendeel (15) werd voorzien van een z.g. remknie. Alle zuigprothesen werden voorzien van een beweegbare voet d.w.z. met een ingebouwde plantairflexiemogelijkheid.

b. Een conventionele bovenbeenprothese hebben 33 éénzijdig geamputeerden $(60 \%)$ gekregen. (tabel 18).

Voor 4 revalidanten met een éénzijdige bovenbeenamputatie was het niet mogelijk tot prothesevoorziening te komen. Van de revalidanten met een "gemengde amputatie" is in 3 gevallen een conventionele prothese aangemeten en éénmaal een zuigprothese voor de bovenbeenamputatie. Van belang is te vermelden dat bij de conventionele prothese, behalve de remknie (17 maal) ook de knievaststelling (16 maal) is ingebouwd. Wat de prothesevoet betreft is meestal de voet met alleen plantairflexiemogelijkheid gebruikt ( 32 maal), maar ook enkele malen de z.g. combivoet ( 3 maal), waarbij zowel plantair- als dorsaalflexiemogelijkheid aanwezig is.

De conventionele bovenbeenprothese vereist een bevestiging aan het lichaam.

\begin{tabular}{lc}
\hline Prothesebevestiging & aantal \\
\hline Enkelassig Heupscharnier. & 23 \\
\hline Dubbelassig Heupscharnier. & 1 \\
\hline Schouderband. & 7 \\
\hline Corsetophanging. & 5 \\
\hline Selesian-Bandage. & 1 \\
\hline
\end{tabular}

Tabel 19: Bevestiging van canventionele bovenbeenprothese aan het lichaam.

Tabel 19 laat zien welk bevestigingsmechanisme aan het lichaam werd toegepast.

Evenals bij de onderbeenprothesedragers is nagegaan of er een bepaalde regelmaat bestond tussen de definitieve bovenbeenprothese en de leeftijd van de prothesedrager.

Tabel 20: Wat betreft de éénzijdig bovenbeengeamputeerden kan gesteld worden dat van de zuigprothese gebruik gemaakt is voor alle leeftijdsgroepen tot 70 jaar. Er bestaat een voorkeur voor dit type prothese bij de jongere leeftijdsgroepen. Vergeleken met de conventionele prothese is er bij een technisch juist uitgevoerde zuigprothese minder sprake van een "pseudarthrosis" tussen stomp en prothesekoker. Dit komt de resterende propriocepsis m.b.t. het bodemcontact, en dus het looppatroon, ten goede.

Het vacuumprincipe kan echter nadelig zijn bij amputaties op grond van een vaatlijden, terwijl daarnaast de "snugly fitted" zuigprothese in het dragen onaangenaam kan zijn voor een bejaarde patiënt met een nog geringe actieradius en een merendeels zittend leven. 


\begin{tabular}{|l|l|l|l|l|l|l|l|l|}
\hline \multicolumn{10}{|c|}{ Leeftijd in jaren. } \\
\hline Eenz. B.B. & $0-30$ & $30-40$ & $40-50$ & $50-60$ & $60-70$ & $70-80$ & $80-90$ \\
\hline Zuigprothese & 4 & 2 & 4 & 4 & 4 & - & - \\
\hline Conventioneel & 1 & 1 & - & 7 & 13 & 11 & - \\
\hline Geen of cosm. proth. & - & - & - & - & 1 & 2 & 1 \\
\hline Dubbelz. B.B. & - & - & - & - & - & - & - \\
\hline Zuigprothese & - & - & - & - & - & - & - \\
\hline Conventioneel & - & - & - & 1 & 1 & 1 & \\
\hline Geen of cosm. proth. & - & - & - & 1 & 1 & \\
\hline "Gemengd" & & - & - & - & 1 & - & - & - \\
\hline Zuigprothese & - & - & - & 2 & 1 & - & - \\
\hline Conventioneel & - & - & - & - & - & - & 1 & - \\
\hline Geen of cosm. proth. & - &
\end{tabular}

Tabel 20: Proshesetype en de leeftijd wan de prothesedrager.

De conventionele prothese is op twee uitzonderingen na uitsluitend boven het 50 ste levensjaar gebruikt.

\begin{tabular}{|c|c|c|c|}
\hline $\begin{array}{l}\text { Opnameduur } \\
\text { in maanden }\end{array}$ & Eenz. BB-amputatie & DBZ. BB-amp. & "gemengde groep" \\
\hline $0-1$ & 2 (1 zonder proth. $)$ & & \\
\hline $1-2$ & 2 & & 1 (zonder proth.) \\
\hline $2-3$ & $5(1$ zonder proth. $)$ & & \\
\hline $3-4$ & 11 & & \\
\hline $4-5$ & 15 ( 2 zonder proth.) & & 2 \\
\hline $5-6$ & 9 & & \\
\hline $6-7$ & 5 & $1 z$ proth. & \\
\hline meer dan 7 & 5 & 2z. proth & 2 \\
\hline
\end{tabular}

Tabel 21: Opnameduur van de bovenbeengeamputeerden al of niet in combinatie met een ampatatie op lager niveau.

Tabel 21: Voor de groep revalidanten met een éénzijdige bovenbeenamputatie, waarvan er één ( 86 jaar) tijdens de opname is overleden, en de groep met een dubbelzijdige bovenbeenamputatie is nagegaan hoe lang zij werden opgenomen in het R.C.H. Bovendien is hieraan toegevoegd de groep "gemengde" amputaties (vijf revalidanten met enerzijds een onderbeenamputatie en anderzijds een bovenbeenamputatie). De gemiddelde opnameduur voor deze 62 revalidanten bedroeg 151 dagen (zie tabel 10).

De kosten van een dergelijke revalidatie bedroegen globaal Fl. 46.000,waarin prothesevoorziening, consulten en onderzoek buiten het R.C.H., maar op verzoek van het amputatieteam, zijn begrepen. 


\section{13 De resultaten van prothesevoorziening en looptraining.}

Uit vele onderzoekresultaten blijkt dat alles in het werk gesteld moet worden om, indien mogelijk, een bovenbeenamputatie te voorkomen. Zo stelt Waters (1976): "All amputee subgroups (vascular above knee, below knee and Syme, traumatic above knee and below knee) with the exception of the patients with vascular above-the-knee amputations had significantly lower oxygen uptake, heartrate and respiratory quotient when walking with a prosthesis than walking with crutches"'.

Uit een onderzoek van Bakker (1973) naar het aantal beenamputaties, verricht in Nederland in 1969, en het aantal verstrekte prothesen, blijkt dat slechts $55 \%$ van de bovenbeengeamputeerden van een prothese werd voorzien. Een zelfde onderzoek in de V.U., geciteerd door Bakker (1973), over de periode 1964 tot 1970 laat zien dat slechts 7 van de 40 bovenbeengeamputeerden met gunstig resultaat van een prothese werden voorzien. Bakker wijst als mogelijke oorzaak van deze matige resultaten op het prae-existent vaatlijden, waardoor langdurige ziekenhuisopnamen met vaak meerdere vaatoperaties. Voor de geamputeerden op grond van een vaatlijden geldt dit echter nog steeds. Bakker pleitte reeds toen voor een goede prae-operatieve begeleiding, voor een nauwe samenwerking en begrip tussen chirurg en amputatieteam, voor de aanwezigheid in het team van een maatschappelijk werkende en orthopaedisch instrumentmaker, kortom voor een zekere centralisatie van deze werkmethode, waardoor het verkrijgen van ervaring mogelijk wordt.

Het lijkt juist opnieuw te wijzen op het relatief hoge aantal bovenbeengeamputeerden in de door het R.C.H. onderzochte groep van 125 patiënten, waarbij van de in totaal 143 amputaties 68 verricht werden op bovenbeenniveau (47.5\%).

Dit in vergelijking met Karthaus (1973), die in zijn onderzoek in $197338.2 \%$ bovenbeengeamputeerden telt, terwijl Bakker voor geheel Nederland in 1969 een percentage van $64.1 \%$ extrapoleert.

Murdoch (1977) wijst erop dat de ter beschikking staande hulpmiddelen (aortografie, huidtemperatuurmeting, plethysmografie, oscillometrie en clearance bepalingen van radio-actief xenon) geen van alle voldoende zekerheid geven over het amputatieniveau en dat de bevindingen tijdens de operatie van doorslaggevende betekenis zijn. Te vaak wordt volgens hem de knie opgeofferd.

Taks (1978) stelt: "'Elke vaatchirurg weet uit eigen ervaring dat de atherosclerotische afwijkingen die op het arteriogram te zien zijn, tijdens de operatie veel uitgebreider kunnen zijn dan men verwacht. Omgekeerd zou angiografisch onderzoek obstructies doen vermoeden die er niet zijn"'. Taks verwijst naar Strandness (1965), die erop gewezen heeft dat het onmogelijk is met behulp van angiografisch onderzoek de haemodynamische betekenis van een stenose op de juiste waarde te schatten. 


\begin{tabular}{|c|c|c|c|c|c|c|c|c|c|}
\hline \multirow[t]{3}{*}{ Hulpmiddel } & \multicolumn{9}{|c|}{ Loopresultaat } \\
\hline & \multicolumn{3}{|c|}{ Goed } & \multicolumn{3}{|c|}{ Redelijk } & \multicolumn{3}{|c|}{ Niet mogelijk } \\
\hline & $\mathrm{BB}$ & DBB & $\mathrm{OB} / \mathrm{BB}$ & $\mathrm{BB}$ & DBB & $\mathrm{OB} / \mathrm{BB}$ & $\mathrm{BB}$ & DBB & $\mathrm{OB} / \mathrm{BB}$ \\
\hline Geen & 1 & & & 6 & & & & & \\
\hline 1 Handstok & 7 & & & 7 & & & & & \\
\hline 2 Handstokken & 4 & & 1 & 3 & & $\mathbb{1}$ & & & \\
\hline 1 Elleboogkruk & & & & 1 & & & & & \\
\hline 2 Elleboogkrukken & 19 & & 1 & 1 & & & & & \\
\hline Looprekje & 2 & & 1 & & & & & & \\
\hline Cosm. Prothese & & & & & & & & 1 & \\
\hline Rolstoel & & & & & & & 3 & 2 & 1 \\
\hline Totaal & 33 & & 3 & 18 & & 1 & 3 & 3 & 1 \\
\hline
\end{tabular}

Tabel 22: Resultaten van looptraining en prothesevoorziening bij:

54 eenzijilige bovenbeenamputaties.

3 dubbelzijdige bovenbeenamputaties.

5 "gemengde dubbelzijilige amputaties.

Een van de 63 opgenomen bovenbeengeamputeerden overleed tijdens de opname..

Tabel 22 laat voor de diverse categorieën van bovenbeengeamputeerden (al of niet dubbelzijdig, of gecombineerd met een onderbeenamputatie) de resultaten zien.

Drie dubbelzijdig bovenbeengeamputeerden zijn niet tot lopen met een prothese gekomen:

- een 75 -jarige vrouw met een dubbelzijdige bovenbeenamputatie werd gedurende 6 maanden in het R.C.H. opgenomen. $Z_{i j}$ moest afzien van revalidatie vanwege een slechte cardiale toestand, restwerschüjnselen van een cerebrovasculair accident en een hypertensie. Zij werd rolstoelpatiënte.

- Een 63-jarige vrouw met een dubbelzijdige bovenbeenamputatie moest na een opname wan I jaar genoegen nemen met een rolstoel, aangezien haar cardiale toestand prothesevoorziening en looptraining niet toeliet.

- Een 52 -jarige vrouw met een dubbelzijdige bovenbeenamputatie vanwege vasculaire insufficiêntie, gecombineerd met diabetes welke moeilijk instelbaar was, werd rolstoelgebruikster vanwege haar slechte algemene toestand en een slechte visus.

Van de revalidanten met een éénzijdige bovenbeenamputatie werd 5 maal van verdere revalidatie afgezien. Eenmaal wegens het overlijden van een 86-jarige man, die reeds liep met behulp van een prothese en 2 stokken. Eenmal wegens een haemoptoë bij een primair longcarcinoom bij een 69 jarige man. Driemaal wegens cardiale bezwaren bij twee mannen van respectievelijk 72 en 78 jaar en een vrouw van 69 jaar, die bovendien symptomen van een meer of minder ernstige dementie toonden.

De lange duur van opname blijkt naast pogingen tot revalidatie vooral verlengd vanwege de moeilijkheden samenhangend met de huisvesting elders, te weten bejaardenhuis of verpleegkliniek. 


\begin{tabular}{|c|c|c|c|}
\hline $100 \%$ & Gunstig resultaat & Tabel volgens Vaucher & Aantal \\
\hline & & 1. Bedlegerig & - \\
\hline & & 2. Rolstoel & 7 \\
\hline & \multirow{4}{*}{$88,7 \%$} & 3. Loopt met prothese thuis. & 25 \\
\hline & & 4. Lopen met 2 handstokken. & 9 \\
\hline & & 5. Lopen met 1 handstok. & 14 \\
\hline & & 6. Zelfstandig lopen. & 7 \\
\hline \multicolumn{2}{|l|}{0} & Totaal & 62 \\
\hline
\end{tabular}

Tabel 23: Laopresultaten vam de groep bovenbeengeamputeerden gemeten volgens de classificatie van Vaucher.

Tabel 23 laat de loopresultaten nogmaals zien maar nu ingedeeld volgens Vaucher. Evenals bij de loopresultaten van de onderbeengeamputeerden wordt met "gunstig resultaat" bedoeld een plaatsing ten aanzien van dit loopresultaat in een der classificaties $3 \mathrm{t} / \mathrm{m} 6$ van Vaucher. Ook hier geldt dat bij de categorie 3 "Loopt met prothese thuis" de patiënten begrepen worden die lopen met elleboogkrukken, maar toch nog een korte wandeling buitenshuis kunnen maken.

$88.7 \%$ van de bovenbeengeamputeerden bereikten een gunstig resultaat. Dit resultaat is mede te danken aan de consequente multidisciplinaire begeleiding met als rode draad de objectieve controle op hart- en longfunctie met behulp van cardiotelemetrisch- en longfunctie-onderzoek. Zonder twijfel hebben psycholoog, maatschappelijk werkende en ergotherapeut, die ter beschikking staan van de afdeling geamputeerden aan dit gunstig resultaat een belangrijke bijdrage geleverd.

\section{V.14 De activiteiten van de maatschappelijk werkende.}

De bijdrage van de maatschappelijk werkende in het amputatieteam is van grote betekenis.

Ook voor de revalidatie geldt hetgeen Romme (1977) stelt ten aanzien van het medisch maatschappelijk werk in de intramurale zorg in het algemeen: "Een optredende psychosociale stoornis, die zich uit in "dysfunctie" wordt voor de patiënt - cliënt een stoornis in zijn gezondheid, omdat hij ook zijn "sociaal" dysfunctioneren als ziekte presenteert. Een deel van het dysfunctioneren berust op stoornis in de lichamelijke of geestelijke conditie van de mens. Een ander deel berust op de interactie tussen de mens en de hem omringende maatschappij, dat wil zeggen een maatschappij met een bepaalde structuur en een cultuur die voor de betrokkene door de mensen om hem heen wordt gerepresenteerd. Deze interactie is het werkterrein, waar het maatschappelijk werk zijn bijdrage levert. Omdat deze bijdrage in het geheel van de gezondheidszorg alleen kan worden verwezenlijkt in een multidisciplinaire samenwerking kan het maatschappelijk werk in de gezondheidszorg alleen maar goed functioneren als zij in de medische setting is ingebouwd".

Van de problemen waarmee de maatschappelijk werkende te maken krijgt bij de confrontatie met geamputeerden wordt een overzicht gegeven in tabel 24. 


\begin{tabular}{llr}
\hline Materieel & Vervoer & 70 \\
\hline & Huisvesting & 71 \\
\hline & Beroep en werkkring & 17 \\
\hline & Diversen & 9 \\
\hline & & 21 \\
\hline Immaterieel & Acceptatie van de handicap & 22 \\
\hline & Motivatie voor revalidatie & 15 \\
\hline & Relatie- en huwelijksproblemen & 12 \\
\hline & Heimwee, angst, eenzaamheid, depressie & \\
\hline & & 45 \\
\hline Contacten met derden & Familie & 115 \\
\hline & Extern (buiten R.C.H.) & 22 \\
\hline & Intern (binnen R.C.H.) & 9 \\
\hline & Diversen & \\
\hline
\end{tabular}

Tabel 24: Behandelde problematiek door maatschappelijk werkende.

Om de betreffende maatschappeli.jke revalidatieproblematiek te inventariseren heeft de maatschappelijk werkende een intake-gesprek met iedere revalidant. Bij $40 \%$ van de revalidanten is een regelmatig tot frequent contact (minimaal $1 \mathrm{x}$ per week) en bij $34.4 \%$ van de revalidanten is weinig contact geweest (enkele malen, afhankelijk van de opnameduur). Bij de overige revalidanten $(25.6 \%)$ is of alleen sprake geweest van een intake-gesprek, of er is geen bemoeienis geweest.

\section{Immateriële problematiek.}

Het eerste intake-gesprek beperkt zich tot het verzamelen van een aantal gegevens over de psycho-sociale situatie en het verstrekken van informatie over het doel van de revalidatie en de mogelijkheden die het centrum biedt. Tijdens dit gesprek kan een zodanige vertrouwensrelatie worden gelegd dat een adequate benadering van de psycho-sociale problematiek mogelijk wordt. Begrijpelijk is dat ook ten deze een goede en nauwe samenwerking met de andere leden van het team en in het bijzonder met de psycholoog noodzakelijk is.

Een teamvergadering vindt $1 \mathrm{x}$ per week plaats. Daarin wordt de revalidant na 2 a 3 weken voor het eerst besproken. Elk teamlid heeft dan vanuit zijn eigen deskundigheid de problemen van de revalidant kunnen benaderen en zich hier een oordeel over kunnen vormen. In deze teamvergadering wordt dan het revalidatiebeleid bepaald. Bijsturen en vervolgen van dit beleid gebeurt dan rond elke revalidant na 4 tot 6 weken. Het spreekt vanzelf dat veelvuldig contact tussen de teamleden onderling bestaat buiten deze teamvergaderingen, wanneer disciplinegebonden problemen dit noodzakelijk maken. De revalidant maakt de teambesprekingen niet mee, maar is wel aanwezig bij overleg omtrent een speciaal hem betreffend vraagstuk. ( huisvesting, vervoer, opleiding etc.). 
Tabel 24 laat de frequentie zien van de contacten tussen maatschappelijk werkende en revalidanten met betrekking tot voorhanden zijnde problemen bij de onderzochte groep van 125 patiënten. Deze rubricering pretendeert niet een volledig beeld te geven van de niet te tellen gesprekken tussen maatschappelijk werkende en revalidant omtrent de genoemde rubrieken. Uit de aard van de problemen die de maatschappelijk werkende met betrekking tot immateriële problematiek heeft komt nogmaals naar voren dat nauwe samenwerking met het behandelteam in het algemeen en de psycholoog in het bijzonder onontbeerlijk is.

\section{Materièle problematiek.}

Vervoer.

Het vervoer kan betrekking hebben op een rolstoel in zijn diverse vormen tot een aangepaste eigen auto of een auto in bruikleen. De auto, al of niet in bruikleen en al of niet aangepast, levert minder reden op tot contact tussen maatschappelijk werkende en revalidant dan het eventueel noodzakelijk zijn van een rolstoel. Dit laatste betekent èn voor de revalidant èn voor zijn milieu een ernstige zaak. Immers: "dan ben je pas echt gehandicapt, want het is zichtbaar voor iedereen". De acceptatie van een rolstoel bleek voor veel revalidanten reden te zijn de hulp van de maatschappelijk werkende in te roepen $(35 \%)$.

\section{Huisvesting.}

De materiële problematiek bestaat echter voornamelijk uit problemen met betrekking tot de huisvesting, hetzij een nieuwe behuizing (verpleegkliniek, bejaardenhuis of aangepaste woning) hetzij aanpassingen die noodzakelijk zijn in de aanwezige woonsituatie. Bij aanpassingen in de voorhanden zijnde woning is het de maatschappelijk werkende, die samen met de ergotherapeut een huisbezoek brengt. Aan de hand van een A.D.L.-check (A.D.L.: Activiteiten van het Dagelijks Leven) en/of huishoudtraining wordt met de revalidant nagegaan welke aanpassingen en/of hulpmiddelen noodzakelijk zijn voor een zoveel mogelijk zelfstandig functioneren in de eigen woning. Waar dit alles gerealiseerd moet worden via de dienst Verstrekkingen (een onderdeel van het R.T.H.), welke dienst weer een intensief contact onderhoudt met de betalende instanties, is het duidelijk dat hier raakvlakken zijn voor diverse disciplines.

Deze raakvlakken kunnen aanleiding zijn tot misverstanden, die een goede samenwerking, zoals in Hoofdstuk IV beschreven, uiterst belangrijk maken. Overigens geldt dit ook voor het realiseren van eventueel vervoer, waar maatschappelijk werkende, ergotherapeut en dienst Verstrekkingen eveneens nauw met elkaar dienen samen te werken.

\section{Beroep en werkkring.}

Ondanks de vrij hoge leeftijd van de gehele groep is 17 maal op dit gebied hulp geboden. Hierbij wordt binnen de Stichting de afdeling VIA (Voorbereiding, Inschakeling Arbeidsproces) ingeschakeld. 


\section{Diversen.}

- Uitkeringen (A.A.W.W.A.O., A.B.W., Invaliditeitspensioen).

- Beroepszaken.

\section{Contacten met derden.}

Een enorm scala van instanties is benaderd en het is op dit terrein, dat de maatschappelijk werkende vaak "alleen" bezig is.

\begin{tabular}{lrr}
\hline Familie & & 45 \\
Extern & 36 \\
& - G.M.D. en Bedrijfsverenigingen & 26 \\
& - Directeur van Bejaardenhuizen, Verpleeghuizen etc. & 19 \\
- Verzekeringsinstanties & 4 \\
- Centraal Bureau voor Rijvaardigheid & 8 \\
- Gewestelijk arbeidsbureau en Werkgevers & 14 \\
- Maatschappelijk Werk elders (verwijzingen) & 8 \\
Intern - Instituut voor Revalidatietechniek "Hoensbroeck" & 22 \\
Diversen - Scholen & 4 \\
- Gezinszorg & 2 \\
- Makelaar, Advocaat, Belastingconsulent & 3 \\
\hline
\end{tabular}

Tabel 25: Contacten met derden.

Tábel 25 geeft een overzicht van deze contacten, die duidelijk de opvatting van Romme (1977) onderstrepen dat maatschappelijk werk in de gezondheidszorg alleen maar goed kan functioneren, als het in de medische setting is ingebouwd.

\section{15 De activiteiten van de psycholoog.}

De afdeling waar geamputeerden gerevalideerd worden, wordt steeds door dezelfde psycholoog verzorgd. In de afgelopen jaren is er een systematische benadering ontwikkeld, welke nu bestaat uit: intake, diagnose, therapie en advies.

\begin{tabular}{lrccccccc}
\hline & Intake & \multicolumn{2}{c}{$\begin{array}{c}\text { Diagnose } \\
\text { via }\end{array}$} & \multicolumn{2}{c}{$\begin{array}{c}\text { Therapie } \\
\text { via }\end{array}$} & \multicolumn{2}{c}{$\begin{array}{c}\text { Advies } \\
\text { via }\end{array}$} \\
& & gesprek & test & team & psych. & B.K.A. & derden \\
\hline B.B. & 22 & 15 & 5 & 10 & 8 & 5 & 5 \\
O.B. & 30 & 16 & 5 & 14 & 6 & 3 & 7 \\
Syme & 1 & 1 & & 1 & & & \\
\hline Totaal & 53 & 32 & 10 & 25 & 14 & 8 & 12 \\
\hline
\end{tabular}

Tabel 26: Bemoeienis van de psycholoog met 125 revalidanten.

Uit de getallen van tabel 26 , welke hierop betrekking hebben, kan geen volledige indruk worden verkregen, aangezien in de periode waarop dit onder- 
zoek betrekking heeft de methode van werken door de psycholoog wijzigingen heeft ondergaan.

Op een totaal van 53 intake-gesprekken is bij 38 revalidanten (16 bovenbeengeamputeerden, 21 onderbeengeamputeerden en I patiënt met een Symeexarticulatie) de bemoeienis voortgezet. Dit betekent een intensief contact van de psycholoog met $30.4 \%$ van de groep van 125 revalidanten.

\section{Intake.}

Tegenwoordig maakt de psycholoog enkele dagen na opname kennis met de patiënt, waardoor het eerste contact gelegd wordt. Anders dan voorheen gebeurt dit nu met vrijwel alle revalidanten. Dit verklaart mede het lage aantal intake-gesprekken (53), die plaatsvonden bij de onderzochte groep.

De psycholoog maakt deel uit van het team. De bevindingen van de psycholoog worden met de revalidant besproken. Na dit gesprek en in overleg met het team wordt besloten of de contacten worden voortgezet in de vorm van een bepaalde therapie of een advies.

Regelmatig komt het voor dat, waar in eerste instantie na het intake-gesprek geen verdere contacten nodig leken, deze naderhand toch wel noodzakelijk bleken, gezien de problemen ontstaan tijdens het revalidatieproces. Dit hernieuwde contact blijkt zelden op initiatief van de revalidant tot stand te komen.

\section{Diagnose.}

Wanneer dit nodig lijkt en wanneer de revalidant hiermede instemt, wordt testonderzoek gedaan, waarbij de meest voorkomende indicatiegebieden zijn: Traumatisering door de problematiek rondom de handicap en beroepskeuzeadvies (BKA).

Het testonderzoek heeft betrekking op een of meer van de volgende deelgebieden:
a. intelligentie en schookennis.
b. gedragsdeviaties.
c. motivaties.
d. interesse.

Met 32 revalidanten zijn gesprekken gevoerd voor nadere diagnostiek en bij 10 wan hen is een testonderzoek verricht. 8 maal werd dit testonderzoek gedaan ten behoeve van een beroepskeuzeadvies (BKA). $B$ ij 2 revalidanten is een nader onderzoek naar de persoonlijkheidsstructuur gedaan.

\section{Therapie.}

Het contact van de psycholoog met de revalidant, in samenwerking en in overleg met het behandelteam, zal zich veelal richten op het leren hanteren van de handicap vanuit de eigen identiteit van de revalidant.

Dit probeert de psycholoog te bevorderen met behulp van drie methoden:

a. individuele gesprekken; dit is bij 14 personen het geval geweest.

b. begeleiding van het behandelteam en via teamleden naar de revalidant. Deze methodiek is bij 25 revalidanten gebruikt. 
c. gespreksgroepen van revalidanten ter ondersteuning van het revalidatieproces met de psycholoog als gespreksleider.

Met deze laatste methode werd bij de onderzochte groep van 125 revallidanten vooralsnog te weinig ervaring opgedaan om hieruit bepaalde conclusies te kunnen trekken.

\section{Advies.}

Bij 8 revalidanten is een advies opgesteld in het kader van een beroepskeuze. Bij deze revalidanten is meestal sprake van een verder intensief contact met de VIA (Voorbereiding Inschakeling Arbeidsproces), de G.A.B. (Gewestelijke ArbeidsBureaus) en de G.M.D. (Gemeenschappelijk Medische Dienst).

Ook zijn voor verschillende revalidanten adviezen aan derden verstrekt, zoals huisarts, psychiatrisch centrum, de G.G.Z. (Geestelijke GezondheidsZorg) etc. Tenslotte is belangrijk het contact met- en het advies aan gezinsleden, ouder's en kinderen van de revalidanten. Ook hieraan is, waar nodig, aandacht besteed.

Vermeld dient nog dat zowel de maatschappelijk werkende als ook de psycholoog deze taak, zoals bij beide disciplines beschreven, ook voor alle andere op afdeling II opgenomen patiënten hadden. (amputaties van de bovenste extremiteiten, orthopaedische afwijkingen, welke tot restverschijnselen of een handicap voerden). In het kader van deze studie zullen deze niet ter sprake komen.

\section{16 De activiteiten van de ergotherapeut.}

Het contact tussen revalidant en ergotherapeut wordt in een vroeg stadium na opname gelegd.

De taak van de ergotherapeut met betrekking tot een beengeamputeerde is drieledig en heeft betrekking op:

a. Prothesetraining.

b. Huisbezoek en voorzieningen.

c. Eventueel rolstoeladvies en rolstoeltraining.

Ad a. Prothesetraining.

Steeds wordt gepoogd in te haken op het programma van de afdeling fysiotherapie en het stadium waarin de revalidant zich op dat moment bevindt.

Globaal kan het te volgen therapieprogramma van de ergotherapeut weergegeven worden in twee fasen:

1. - Voorbereidende oefeningen ter verbetering van de algemene conditie.

- Spierversterkende oefeningen voor de bovenste extremiteiten.

- Trainen van de zit- en sta-balans.

2. - Oefeningen met de voorlopige prothese.

- Belasten van de amputatiestomp.

- Trainen van de sta-balans.

- Bevorderen van het spontane gebruik van de prothese. 
In de eerste fase wordt vooral gewerkt aan verbetering van de algemene en specifieke omstandigheden. Door middel van hout- en metaalbewerking wordt vanuit verschillende houdingen gewerkt om de zitbalans te verbeteren. Dit gebeurt zittend op een stoel, aanvankelijk met rug- en armsteun en in een later stadium zonder rugsteun en tenslotte ook zonder armleuning. Deze fase kan dan ook afgesloten worden met het werken, zittend op een kruk. Naast het trainen van de zitbalans wordt ook een spierversterking van de bovenste extremiteiten nagestreefd met behulp van zagen, gutsen en smeedwerk. Ook dit gebeurt aanvankelijk zittend voor het terugvinden van de zitbalans. Later worden deze technieken uitgevoerd in staande houding (op het resterende been) om de sta-balans te oefenen. Bovendien wordt in deze houding timmeren verfwerk verricht. Dat technieken als weven, het maken van linosneden, macramé- en Smyrnawerk etc. mogelijk zijn, maakt de motivatie van de revalidant alleen maargroter. Immers, ergotherapie streeft slechts een doel na: het doen mogelijk maken.

Wanneer op deze wijze, in samenwerking met de arts, verpleging en fysiotherapeut de omstandigheden, zoals cardiopulmonale toestand, spierkracht, evenwichtsgevoel en ook de specifieke verhoudingen in de amputatiestomp dit toelaten, komt de revalidant in de tweede fase van het revalidatieproces.

Op dit moment is de prothese "in de pas" aangemeten. In samenwerking met de fysiotherapeut wordt het therapieprogramma van de revalidant zodanig ingedeeld dat de vorderingen in staan en lopen gevolgd kunnen worden door de ergotherapeut. Zo zal op een gegeven moment staande gewerkt worden om de amputatiestomp langzaam aan langere belasting bloot te stellen. De tijd die tussen de verschillende fasen verloopt is uiteraard zeer individueel bepaald. Zodra de revalidant kan lopen met elleboogkrukken c.q handstokken zal hij de afstand van zijn kamer op de afdeling naar de afdeling ergotherapie nog afleggen rijdlend in een rolstoel, maar lopend zijn plaats bereiken in de afdeling ergotherapie. Er wordt dan afwisselend staand en zittend gewerkt. Halen en wegbrengen van materialen en gereedschappen wordt zo pas mogelijk wanneer de revalidant lopen kan met I loophulp ( kruk of stok). In dit stadium wordt ook, indien noodzakelijk, begonnen met de huishoudtraining. Deze bestaat onder meer uit het bezig zijn in de modelkeuken van de afdeling ergotherapie. Er wordt nagegaan in hoeverre zelfstandig huishoudelijke werkzaamheden verricht kunnen worden. Tevens worden de A.D.L.'s (Aktiviteiten van het Dagelijks Leven) geoefend. Zo mogelijk wordt verder gegaan naar training zonder gebruik te maken van loophulpen. De observatie door de ergotherapeut tijdens de A.D.L.-check en de huishoudtraining zijn van belang in verband met bepaalde hulpmiddelen of aanpassingen in de woonsituatie na ontslag uit het Revalidatiecentrum.

\section{Ad b. Huisbezoek en voorzieningen.}

Naast het werken samen met de revalidant om met de prothese te leren functioneren wordt aandacht besteed aan de thuissituatie. Bij vrijwel iedere prothesedrager wordt een huisbezoek afgelegd, meestal samen met de maatschappelijk werkende en/of arbeidsdeskundige van de G.M.D. Indien gewenst wordt het huisbezoek meegemaakt door de betreffendle revalidant. Dit huis- 
bezoek wordt in een zo vroeg mogelijk stadium gemaakt ter oriëntatie; op dat moment is het eindstadium van het revalidatieproces nog niet bekend. Indien dit eindresultaat na verloop van tijd wel bekend is, wordt een rapport opgesteld, waarin de woonsituatie tot in details wordt beschreven en getekend. Indien nodig worden adviezen gegeven voor aanpassingen, voorzieningen en verbouwingen. Het uitwerken van een huisbezoek in een later stadium is mede oorzaak van veel ongemak, omdat de grotere voorzieningen een lange administratieve weg afleggen, voordat zij te realiseren zijn. Voor meerdere revalidanten heeft dit de opnameduur verlengd.

De adviezen met betrekking tot de woonsituatie zijn globaal te verdelen in grote en kleine voorzieningen:

Kleine voorzieningen:

- beugels, handgrepen.

- toiletverhoger.

- badbankje.

- douchezitje.

- extra leuning/trap.

- speciale stoel, zitkussen.

- verwijderen of afwlakken van drempels.

- hulpmiddelen voor de huishouding (dienwagen, werkstoel e.d.).

Grote voorzieningen:

- doorbreken van muren.

- verbreden van doorgangen.

- verplaatsen van toiletpot.

- uitbreken van lavet.

- vergroten natte cel.

- verbouwing keuken.

- aanbouwen van slaapkamer en/of natte cel.

Ad c. Rolstoeladvies en rolstoeltraining.

Indien een rolstoel nodig is wordt samen met de ergotherapeut een rolstoeladvies opgesteld door het rolstoelteam. Op de zogenaamde rolstoelpasdag wordt de definitieve versie vastgesteld. Op deze rolstoelpasdag zijn verschillende deskundigen aanwezig, zoals een ingenieur (het hoofd van het centrum R.T.H.), een revalidatie-arts, een onderhoudstechnicus en de administratieve kracht van de afdeling verstrekkingen (een onderdeel van het R.T.H.). Laatstgenoemde is de verbindingsman tussen het Revalidatiecentrum en de betalende instanties. De afdeling ergotherapie verzorgt ook de rolstoeltraining met een rolstoel uit het rolstoelendepôt, wanneer de definitieve toekomstige rolstoel geadviseerd is.

Bij ruim $50 \%$ van de revalidanten van de onderzochte groep heeft de ergotherapeut een rolstoeladvies en/of een advies ter zake van grotere woonvoorzieningen uitgewerkt. Het bleek helaas niet mogelijk over de onderzochte groep gedetailleerde gegevens te verzamelen van de verstrekte adviezen en uitgevoerde voorzieningen. 


\section{17 Uiteindelijke resultaten.}

Belangrijk, en dan niet alleen voor een amputatieteam maar zeker nog meer voor de revalidant is de vraag naar de huisvesting na ontslag uit het Revalidatiecentrum.

\begin{tabular}{lc}
\hline Terug naar huis & $\begin{array}{c}\text { Aantal ge- } \\
\text { revalideerden }\end{array}$ \\
\hline Terug naar Bejaardenhuis & 92 \\
\hline Naar Verpleeghuis & 10 \\
\hline Naar aangepaste woning & 5 \\
\hline Naar Bejaardenhuis & 8 \\
\hline Naar Gezinsvervangend Tehuis & 6 \\
\hline Tijdens opname overleden & 2 \\
\hline Onbekend & 1 \\
\hline
\end{tabular}

Tabel 27: Huisvesting na revalidatie.

Tabel 27 maakt melding van de plaatsing na ontslag. Hieruit blijkt dat 110 van de 125 patiënten teruggingen naar huis, naar het bejaardenhuis vanwaar zij kwamen of naar de vroegere huisvesting, maar nu aangepast aan de handicap. $88 \%$ van de patiënten kon dus teruggeplaatst worden in hun vertrouwde milieu. Een percentage dat, gezien vanuit het mens-machinemilieu systeem, niet onderschat moet worden.

Slechts 5 patiënten vonden na ontslag huisvesting in een verpleegkliniek en kwamen financieel, afgezien van de eigen A.W.B.Z.-bijdrage, dus volledig ten laste van de gemeenschap. Bij andere patiënten was dit slechts ten dele of in het geheel niet het geval.

Natuurlijk is bij een onderzoek vergelijking van de uiteindelijke resultaten met die van andere onderzoekers van grote betekenis. Met Karthaus (1973) kan gesteld worden dat het toepassen van een statistische analyse op de uiteindelijke resultaten van de revalidatie bij de onderzochte groep patiënten weinig zinvol is, gezien de vele bekende en wellicht ook onbekende variabelen. Bovendien zijn er een aantal factoren die niet in maat en getal zijn uit te drukken, maar wel belangrijke voorwaarden vormen, wil het uiteindelijk resultaat zo goed mogelijk zijn.

Deze factoren zijn:

- de goede teamgeest, waartoe heeft bijgedragen het feit dat vrijwel alle teamleden, in juni 1972 bij de behandeling betrokken, ook nu nog deel uit maken van dit team.

- de geografische, gemakkelijk bereikbare, ligging van het Revalidatiecentrum dat daardoor geen obstakel vormt voor frequent contact met het thuisfront. 
- de vitgebreide recreatieve mogelijkheden.

- de mogelijkheden die het S.K.W. (Sociaal Kultureel Werk) biedt.

- het feit dat bijna alle teamleden Limburgers zijn, waardoor ook bij de therapeutische benadering van de revalidanten het Limburgs dialect de voertaal is. Een factor die belangrijk kan zijn wanneer bejaarde mensen hun problemen onder woorden moeten brengen.

- het feit dat het Revalidatiecentrum 'Hoensbroeck" een aparte afdeling heeft, waar nagenoeg alleen geamputeerden gerevalideerd worden door een amputatieteam dat nagenoeg alleen deze revalidatie tot dagtaak heeft.

Deze niet in maat en getal uit te drukken factoren zijn mogelijk van veel invloed geweest, wanneer men conclusies zou willen trekken uit een "vergelijking" met het onderzoek van Karthaus (1973) in het begin van de zeventiger jaren en van der Tempel (1978), die in hetzelfde tijdvak als dat van de onderhavige studie een onderzoek deden bij patiënten met één of meer amputaties van de onderste extremiteit.

Karthaus (1973) verrichtte een onderzoek bij 70 patiènten, bij wie een amputatie van de onderste extremiteit werd verricht. 63 van deze patiënten ondergingen de amputatie vanwege arteriosclerotisch gangreen. 13 van deze 63 patiënten kwamen niet in aanmerking voor de methode van onmiddellijk postoperatieve prothesevoorziening en mobilisatie. Er resteerden dus 50 patiënten (met in totaal 55 amputaties), waarbij het onderzoek naar onmiddellijk postoperatieve prothesevoorziening en mobilisatie kon plaatsvinden.

De gemiddelde amputatieleeftijd (de kalenderleeftijd van de patiënt op de dag van amputatie) bedroeg 73 jaar met een minimum van 47 en een maximum van 87 jaar. Bij het onderzoek waren 26 mannen en 24 vrouwen betrokken. De gemiddelde amputatieleeftijd voor mannen bedroeg 72 jaar (minimum 47 , maximum 87 jaar). Voor de vrouwen was dit 74 jaar (minimum 57 jaar, maximum 85 jaar).

\begin{tabular}{lccc}
\hline Amp. niveau & Karthaus & v.d. Tempel & R.C.H. \\
\hline O.B. & $34(61.8 \%)$ & $82(58.1 \%)$ & $72(51.4 \%)$ \\
\hline B.B. & $21(38.2 \%)$ & $59(41.9 \%)$ & $68(48.6 \%)$ \\
\hline Totaal & $55(100 \%)$ & $141(100 \%)$ & $140(100 \%)$ \\
\hline
\end{tabular}

Tabel 28: Vergelijking tussen Karthaus, $v_{n}$ d. Tempel en het R.C.H. wet betrekking tot de percentages van onder-en bovenbeengeamputeerden.

Uit tabel 28 blijkt dat, bij vergelijking van de drie genoemde onderzoekspopulaties, het R.C.H. procentueel meer patiënten met een bovenbeenamputatie ter revalidatie aangeboden kreeg. Het moge duidelijk zijn dat bij de revalidatie van een bovenbeengeamputeerde, zeker op hogere leeftijd, de kans op een gunstig resultaat ten aanzien van de looptraining met daarnaast de kans op terugkeer naar de vroegere woonsituatie minder groot is dan bij een onderbeengeamputeerde het geval is. 
Uiteindelijk bleven bij het onderzoek van Karthaus van de 50 patiènten die voor onderzoek in aanmerking kwamen, 40 patiënten over.

Karthaus verrichtte alle amputaties zelf of hij assisteerde bij de operaties. Bij alle amputaties werden de technieken van myodese en/of myoplastiek toegepast en kon hij, voor zover mogelijk, het optimale amputatieniveau bepalen.

Om een indruk te krijgen of de definitieve prothesen ook aan hun doel beantwoordden werd door Karthaus nagegaan of de patiënten de prothese zelfstandig aan en uit konden trekken en of zij de prothese de gehele dag gebruikten. Dit bleek bij 26 van de $28(92.8 \%)$ onderbeengeamputeerden het geval te zijn, terwijl dit voor de bovenbeen- en knie-exarticulatiepatiënten $66.6 \%$ bedroeg ( 8 van de 12 patiënten). Karthaus deelt zijn patiënten niet in volgens de criteria van Vaucher, maar we mogen aannemen dat een gebruik van de prothese gedurende de gehele dag als een gunstig resultaat mag worden beschouwd. Wat betreft de huisvesting na ontslag deelt Karthaus mee, dat van de 40 patiënten 33 , ofwel $82.5 \%$ terugkeerden naar de voorheen bestaande woonsituatie, terwijl 7 patiënten een nieuwe huisvesting vonden in een verzorgingshuis.

Om een indruk te krijgen hoe de resultaten in Hoensbroek waren, maar nu toegespitst op de patiënten die geamputeerd werden op grond van een vaatlijden, al of niet gecombineerd met diabetes mellitus, werd voor deze patiënten een nieuwe indeling gemaakt.

\begin{tabular}{|l|c|c|c|c|c|c|c|}
\hline Leeftijd & \multicolumn{2}{|c|}{ O.B. } & \multicolumn{2}{c|}{ B.B. } & \multicolumn{2}{c|}{ D.B.Z. } & Totaal \\
\hline & $q$ & $\sigma^{\prime}$ & $q$ & $\sigma^{\prime \prime}$ & $q$ & $\sigma^{\prime \prime}$ & \\
\hline $31-40$ & & $1(36)$ & $1(38)$ & $1(31)$ & & & 3 \\
\hline $41-50$ & & $4(48,2)$ & $1(44)$ & & & $1(48)$ & 6 \\
\hline $51-60$ & $1(57)$ & $5(57,2)$ & & $12(56,5)$ & $2(54)$ & $5(55,2)$ & 25 \\
\hline $61-70$ & $6(66)$ & $6(67,3)$ & $3(64,6)$ & $12(67,4)$ & & $3(65)$ & 30 \\
\hline $71-80$ & $12(73,8)$ & $7(73,3)$ & $4(75,2)$ & $9(72,6)$ & $3(77)$ & & 35 \\
\hline $81-90$ & $1(81)$ & & & & & & 1 \\
\hline \multicolumn{2}{|l|}{ Totaal: } & \multicolumn{7}{|c|}{43} & & & 14 & 100 \\
\hline
\end{tabular}

Tabel 29: Leeftijdsverdeling en amputatieniveau bij 100 geamputeerden $t$.g.v. een vaatijden. De ussen haakjes geplaatste getallen geven de (gemiddelde) leeftijd aan.

Ook in het R.C.H. wordt het behouden van het kniegewricht zeer belangrijk geacht. Er is bij de dubbelzijdig geamputeerden in tabel 29 geen indeling meer gemaakt in de drie bekende niveaus (O.B. - B.B. - K.E.). Echter, bij de onderzochte groep van 100 op vasculaire basis geamputeerden ondergingen 14 personen een dubbelzijdige amputatie, waarbij de knie-exarticulatie beschouwd werd als een amputatie op bovenbeenniveau.

Bij 10 van deze 14 patiënten was een bovenbeenamputatie verricht, terwij 3 patiënten van deze groep aan het andere been eveneens een bovenbeenamputatie ondergingen en 7 patiënten een amputatie op onderbeenniveau. De overige 4 waren beiderzijds op onderbeenniveau geamputeerd. 
In totalal blijkt dan uit tabel 29 dat 53 van deze op grond van een vaatlijden geamputeerden een bovenbeenamputatie ondergingen (53\% tegenover $38.2 \%$ bij Karthaus).

Uit de opmerkingen van Karthaus over lengte van de amputatiestomp en gebruikte operatietechnieken, zowel voor boven-als onderbeenniveau, valt af te leiden dat Hoensbroek minder gunstige uitgangspunten had dan Karthaus. Zo was op onderbeenniveau bij de vaatpatiënten slechts $29 \times$ myodese en/of myoplastiek toegepast. Bij de bovenbeengeamputeerden werd $5 \mathrm{x}$ een myoplastiek toegepast en slechts $1 \times$ een myodese.

Ook had het R.C.H. geen inspraak bij de keuze van de lengte van de amputatiestomp, behalve bij de 13 gevallen (11 O.B. en 2 B.B.) waar al vóór de amputatie de prosthetic surgeon contact had met patiënt en operateur.

Zoals in tabel 10 vermeld, was de gemiddelde tijdsduur, voordat het amputatieteam kennis maakte met de patiënt 69 dagen voor een onderbeengeamputeerde en 92 dagen voor een bovenbeengeamputeerde. Ondanks al deze minder gunstige factoren blijkt dat de resultaten wat betreft de huisvesting na ontslag zeer redelijk genoemd mogen worden, zoals tabel 30 laat zien.

\begin{tabular}{lccccccc}
\hline Leeftijd & $31-40$ & $41-50$ & $51-60$ & $61-70$ & $71-80$ & $81-90$ & \\
\hline Terug naar huis & 3 & 5 & 21 & 22 & 30 & 1 & 82 \\
\hline Naar Bejaardenhuis & & & & 5 & & & 5 \\
\hline Naar Verpleeghuis & & 1 & 1 & & 1 & 3 \\
\hline $\begin{array}{l}\text { Verhuizing naar } \\
\text { aangepaste woning }\end{array}$ & & & & & & \\
\hline Terug naar Bejaardenhuis & & & 1 & 2 & 3 \\
\hline Terug naar Verpleeghuis & & & & 1 & & 1 \\
\hline Totaal & 3 & 6 & 25 & 30 & 35 & 1 & 100 \\
\hline
\end{tabular}

Tabel 30: Huisvesting wa 100 geamputeerden t.g.e. en vaatidden na revalidarie.

92 patiënten keerden terug naar hetzelfde milieu als voor hun opname in ziekenhuis en Revalidatiecentrum het geval was. Karthaus haalt bij een beduidend minder groot aantal patiënten, namelijk 40 , een percentage van $82.5 \%$.

Belangrijk is erop te wijzen dat de patiènten die een nieuwe huisvesting vonden in een bejaardenhuis niet of slechts ten dele ten laste van de gemeenschap kwamen. Dit geldt wel voor slechts 3 patiënten, waar een plaatsing in een verpleegkliniek niet te voorkomen was.

Voor deze groep van 100 geamputeerden werd nagegaan hoe zij functioneerden met hun prothese volgens de criteria van Vaucher.

Uit tabel 31 blijkt dat de resultaten bij poliklinische controle in april 1978 soms slechter, soms beter waren. Opgemerkt dient te worden dat van deze 100 op vasculaire basis geamputeerden bij controle in 197816 patiënten overleden waren. Hun plaats in de categorie van Vaucher werd bepaald door de laatste controle op het prothesespreekuur vóór het overlijden plaats vond. 6 patiënten konden niet meer (via de huisarts) achterhaald worden. 
1. Bedlegerig

bij ontslag

April 1978

2. In rolstoel

1

2

3. Loopt met prothese thuis

4. Loopt met 2 stokken

5. Loopt met I stok

6. Loopt zelfstandig

Onbekend

Tabel 31: Loopresultaten vam 100 geamputeerden f.g.v. een waalijden bij ontslag en bij poliklinische controle.

Het is een ervaringsfeit dat, na het verblijf in een revalidatiecentrum, verbeteringen kunnen optreden voor wat betreft de afhankelijkheid en de soort loophulp. Ook hier geldt: "al doende leert men" en "oefening baart kunst".

De slechtere resultaten, voor sommige patiënten ruim 5 jaar na ontslag, hebben te maken met de algehele veroudering met daarnaast specifieke factoren, zoals optreden of verergering van claudicatio klachten in het eventueel resterende been, cardiale klachten (zeker gelet op de vermeerderde zuurstofbehoefte) of toenemende vermindering van de visus bij diabetes patiënten.

\begin{tabular}{lccc}
\hline & $\begin{array}{c}\text { Onderbeen } \\
\text { geamputeerden }\end{array}$ & $\begin{array}{c}\text { Bovenbeen } \\
\text { geamputeerden }\end{array}$ & $\begin{array}{c}\text { Dubbelzijdig } \\
\text { geamputeerden }\end{array}$ \\
\hline V.d. Tempel & 22.6 & 24.5 & 23 \\
\hline R.C.H. & 16.5 & 20.3 & 31.7 \\
\hline
\end{tabular}

Opnameduur in weken.

Tabel 32. Vergelijking van opnameduur van de onderzoekspopulaties van v. d. Tempel en het R.C.H.

Zoals tabel 32 laat zien bedroeg de opnameduur in het R.C.H. voor 43 onderbeengeamputeerden 16.5 weken. Deze tijd was voor de 43 bovenbeengeamputeerden en de 14 dubbelzijdig geamputeerden respectievelijk 20.3 en 31.7 weken. Een "vergelijking"' met 101 op vasculaire basis geamputeerden, over wie van der Tempel (1978) rapporteerde, leert dat deze cijfers respectievelijk bedroegen $22.6,24.5$ en 23 weken.

Nogmaals moet nadrukkelijk gesteld worden dat vergelijkingen tussen verschillende amputatieteams weinig zinvol zijn, gezien het grote aantal variabelen en factoren die niet in maat en getal zijn uit te drukken. Belangrijk is echter wel dat conform Karthaus (1973) en van der Tempel (1978) ook dit onderzoek in het R.C.H. aantoont dat het wel degelijk zinvol is bejaarden en zelfs hoogbejaarden te revalideren.

Belangrijk voor de bejaarde is niet "hoe hij loopt, maar dat hij loopt". Dit maakt voor hem/haar het verschil uit voor wat betreft de huisvesting na ontslag en voor alle kostendragers de financiële lasten, welke door de gemeenschap moeten worden opgebracht.

De maatschap van mensen is er ten zeerste bij gebaat dat menselijk geluk 
behouden kan blijven tegen zo laag mogelijke kosten. Gepoogd werd aan te tonen dat dit geen contradictio in terminis is, waar vaak het tegendeel wordt verondersteld.

\begin{tabular}{|c|c|c|c|c|c|c|}
\hline \multirow{2}{*}{$\begin{array}{l}\text { Indeling volgens } \\
\text { Vaucher }\end{array}$} & \multirow{2}{*}{$\begin{array}{l}\text { Overleden } \\
\text { tijdens } \\
\text { revalid. }\end{array}$} & \multirow{2}{*}{$\begin{array}{c}\text { nat } \\
\text { ontslag }\end{array}$} & \multicolumn{3}{|c|}{ Nog in leven 1978} & \multirow[b]{2}{*}{ Totaal } \\
\hline & & & $\mathrm{OB}$ & $\mathrm{BB} / \mathrm{HE}$ & $\mathrm{DBZ}$ & \\
\hline 1. Bedlegerig & & 2 & & & & 2 \\
\hline 2. In rolstoel & & 4 & 2 & 4 & 3 & 13 \\
\hline 3. Loopt met prothese & & $A$ & 6 & 12 & 4 & 26 \\
\hline 4. Loopt met 2 stokken & $\mathbb{1}$ & 2 & 8 & 8 & 4 & 23 \\
\hline 5. Loopt met 1 stok & & 3 & 19 & 16 & & 38 \\
\hline 6. Loopt zelfstandig & & 4 & 5 & 5 & 2 & 16 \\
\hline Onbekend & & & 2 & 4 & 1 & 7 \\
\hline Totaal & 1 & 19 & 42 & 49 & 14 & 125 \\
\hline
\end{tabular}

Tabel 33: Revalidatie-resultaat bij de laatste poliklinische controle rond Maart-April 1978.

Tabel 33 geeft aan de uitkomst van een poliklinische controle met betrekking tot de indeling volgens Vaucher, welke in maart-april 1978 werd gehouden.

Van het totaal van 125 revalidanten waren intussen 20 personen overleden. Voor hen werd eveneens de categorie bepaald volgens de normen van Vaucher bij de laatste controle vóór overlijden.

Van de patiënten die in maart-april 1978 nog in leven waren, konden 89 geclassificeerd worden in categorie $3 \mathrm{t} / \mathrm{m} 6$ volgens Vaucher. Dit is met betrekking tot 105 nog in leven zijnde patiënten een percentage van $84.7 \%$. Dat wil zeggen dat voor $84.7 \%$ van de revalidanten bij een controle, die voor meerderen van hen 5 jaar later werd uitgevoerd, een gunstig resultaat nog steeds aanwezig was.

Al is de ervaring van het $\mathbb{R}$.C.H. met betrekking tot geamputeerden van recente datum, toch kan gesteld worden dat absolute contraindicaties slechts zelden aanwezig zijn, wanneer de vraag naar een mogelijk succes van prothesevoorziening en verdere revalidatie beantwoord moet worden. Het R.C.H. heeft enige ervaring met patiënten, waar ernstige cardiale problemen bestonden dan wel stoornissen in de psychische sfeer en desondanks een goed revalidatieresultaat behaald werd.

De enige absolute contraindicatie die gehanteerd werd is de dementie, die al aanwezig was, voordat de ziekte, welke tot amputatie voerde, manifest werd. Indien revalidatie een leerproces is, dan is dit een te zware opgave voor een demente patiënt.

Mochten er andere contraindicaties worden verondersteld, dan zal het amputatieteam deze contraindicaties moeten kunnen verifiëren en beoordelen. De arts, die geamputeerden behandelt, is niet alléén in staat tot oordelen of een bindend advies hieromtrent te geven.

Elke te revalideren patiënt moet na amputatie de kans krijgen om zelf aan den lijve te ervaren of revalidatie, welke streeft naar een hoger functioneel niveau al of niet mogelijk is. 
Gelet op het reeds voorheen vermelde feit dat $80 \%$ der revalidanten ouder was dan 50 jaar en ruim $31 \%$ ouder dan 70 jaar, moge duidelikk zinn dat revalideren van geamputeerden een zinvolle zaak kan zijn.

Bakker (1973) stelde in 1969 vast, dat van alle bovenbeengeamputeerden in Nederland slechts $55 \%$ van een prothese werd voorzien; het merendeel van deze patiënten was ouder dan 70 jaar. Huisvesting in een verpleeghis was zodoende in de zestiger jaren vaak niet te voorkomen. Voor de zeventiger jaren zou dit betekenen dat dan, bij een gemiddelde verpleegprijs van F1 150,per dag na 5 jaar de kosten Fl 273.750 per patiënt zouden bedragen, afgezien van de eigen A.W.B.Z. bijdrage.

De gemiddelde kosten van de revalidatie van een bovenbeengeamputeerde bedroegen in de periode van het onderzoek FI 46.000,-, ook na 5 jaar, afgezien van reparaties aan- of het verstrekken van een nieuwe prothese. Het verschil van meer dan 2 ton wordt tot een gigantisch bedrag, op te brengen door de gemeenschap, wanneer het door Bakker genoemde percentage gehandhaafd zou zijn gebleven. De vergrijzing van de bevolking, alsmede de toename van het aantal geamputeerden in de leeftijdsgroep ouder dan 65 jaar, waarop in hoofdstuk VIII nader zal worden ingegaan, zouden de verpleeggelden tot astronomische waarden doen stijgen. Afgezien van deze kostenfactor, is echter belangrijker dat menselijk welbevinden behouden kan blijven door een verandering in therapeutisch handelen bij een niet te voorkomen verschuiving in de percentages van de leeftijdsgroepen in ons land. 


\title{
Voet-en voetwortelamputaties.
}

\author{
„Syme's amputation still remains a good amputation". (Gillis 1954.)
}

Het als motto gebruikte citaat van Gillis is even actueel als een kwart eeuw geleden. Desondanks is de exarticulatie van Syme in Nederland nagenoeg obsoleet geworden ten voordele van de onderbeenamputatie. Aangezien deze studie een verandering in therapeutisch handelen bij te amputeren patiënten ten doel heeft, lijkt het juist aandacht te vragen voor een amputatieniveau, dat in andere landen dan Nederland wel tot goede resultaten heeft geleid.

,De optimale plaatsen voor amputaties zijn vastgesteld in het najaar van 1954 door de landen van West-Europa. Er waren natuurlijk nogal discussies over de verschillende vormen van amputaties, die werden of worden toegepast aan de benen. Amputeren in het gewricht van Lisfranc werd niet aanbevolen door de Belgen, Fransen en Engelsen; de Nederlanders beschouwen dit nog wel degelijk als bruikbaar. Amputeren in het gewricht van Chopart werd eigenlijk - in verband met de moeilijkheden van het maken en passen van het kunstbeen - door geen der delegaties aanbevolen.

Wat de operatie van Pirogoff betreft, de Fransen en Engelsen voelden er niets voor, de Nederlandse delegatie beschouwde haar nog als bruikbaar. Omgekeerd was het met de operatie van Syme; deze werd in speciale gevallen door de Engelsen zeer aanbevolen, doch de overige delegaties waren er niet erg geestdriftig over, wellicht uit gebrek aan ervaring daarmede". (Bär 1957.)

Bär vervolgt: ,De amputatie in het gewricht van Lisfranc is afgewezen door de Belgen, Fransen en Engelsen; toch hebben orthopaeden in Nederland (evenals ikzelf) gunstige resultaten hiermede bereikt, al verschillen de verstrekte prothesen wel. Een amputatie in het gewricht van Chopart is inderdaad cosmetisch ongunstiger, niet alleen wegens de prothesevoorziening, maar ook omdat de stomp steeds door het behouden zijn van de kuitspieren zonder tegenwerkende spieren in een equinovarusstand gaat staan. De kuitspieren werken immers via de achillespees niet alleen als plantairflexoren, maar door de ietwat mediale insertie aan de calcaneus tevens als supinatoren. Men kan ook nog de achillespees verlengen of beter de spronggewrichten verstijven. Toch heeft een amputatie volgens Chopart nog altijd een voordeel boven de standaard-operatie van het onderbeen. De patiënt houdt bij het lopen het normale contactgevoel tussen stomp en grond en kan zich ook zonder prothese helpen. Bij voorkeur zou ikzelf dus een 
amputatie volgens Lisfranc willen verrichten of volgens Pirogoff. Na amputatie volgens Lisfranc kan patiënt nog steeds zelfstandig. zonder prothese, lopen, ook na amputatie volgens Pirogoff en zelfs nog na die volgens Syme. Ik weet niet of de Syme-operatie in Nederland dikwijls wordt uitgevoerd. In Amerika en Canada zijn velen ower deze amputatie zeer tev reden; men ziet er belangrijke voordelen van. Breslau zegt terecht, dat de standaard-operatie onder de knie , "een te grote prijs is voor een ernstig letsel van de voorvoet".

Breslau (1956) berichtte in 1956 over grote amputaties bij ongevalspatiënten, ressorterende onder de toenmalige Rijksverzekeringsbank. 732 Eenzijdige onderbeenamputaties waren als volgt verdeeld:

$\begin{array}{lr}\text { Voorvoetamputatie } & 11 \\ \text { Lisfranc-amputatie } & 23 \\ \text { Chopart-exarticulatie } & 25 \\ \text { Pirogoff-amputatie } & 37 \\ \text { Syme-exarticulatie } & 2 \\ \text { Onderbeen-amputatie } & 617 \\ \text { Knie-exarticulatie } & 17 \\ & 732\end{array}$

Er werd dus in iets minder dan $0,3 \%$ der gevallen een Syme-exarticulatie verricht.

Bij de dubbelzijdige beenamputatie wordt exarticulatie volgens Syme in het overzicht van Breslau niet aangetroffen, daarentegen wel $2 x$ een exarticulatie volgens Pirogoff en 1x een amputatie volgens Lisfranc.

Een onderzoek naar het aantal geamputeerden in Nederland in 1969 leverde de volgende gegevens op:

,Van een aantal amputaties werd een betrouwbare indruk verkregen door middlel van de gegevens van de Stichting Medische Registratie in Utrecht. Deze Stichting verzamelde in 1969 gegevens van 614.778 in Nederlandse ziekenhuizen opgenomen patiënten. Deze 614.778 opgenomen patiënten vormden $3 / 5$ deel van de totale Nederlandse ziekenhuispopulatie in 1969. De spreiding van de - aan de Stichting deelnemende - ziekenhuizen was zodanig, dat vermenigvuldiging met de factor $5 / 3$ een betrouwbare indruk geeft over de voor geheel Nederland geldende getallen" . (Bakker 1973.)

Bakker stelt vast dat bij 935 amputaties van de onderste extremiteit, slechts 84 voetamputaties werden verricht. Een onderverdeling naar amputatieniveau van de voet wordt niet gegeven. Wij kunnen constateren dat in elk geval minder dan $9 \%$ amputaties verricht werden distaal van het onderbeenniveau.

De belangstelling, welke destijds bestond voor de amputatietechnieken van voet-en voetwortel is gaan dalen. Wanneer het niet gelukt, gezien de aard van de aandoening, een middenvoetstomp te behouden geeft men liever de voorkeur aan de ,,zekere" onderbeenamputatie. De reden hiervan is dat de originele technieken volgens Chopart, Pirogoff en Syme toch wel op den duur bepaalde nadelen bleken te hebben.

Het is de vraag of dit op alle genoemde chirurgen en de door hun beschre- 
ven operatiemethodieken toepasbaar is, gezien de historische ontwikkeling in deze.

James Syme leefde van 1799 tot 1870 in een tijd toen antisepsis en asepsis nog onbekende begrippen waren. Van 1833 tot 1869 was hij verbonden aan de universiteit van Edinburgh. In deze jaren ontwikkelde hij nieuwe operatietechnieken waarvan slechts één ook nu nog gebruikt wordt: de exarticulatie in het bovenste spronggewricht met behoud van een voetzoolhuidlap ten behoeve van eindbelasting van de amputatiestomp. (Fig. 22)

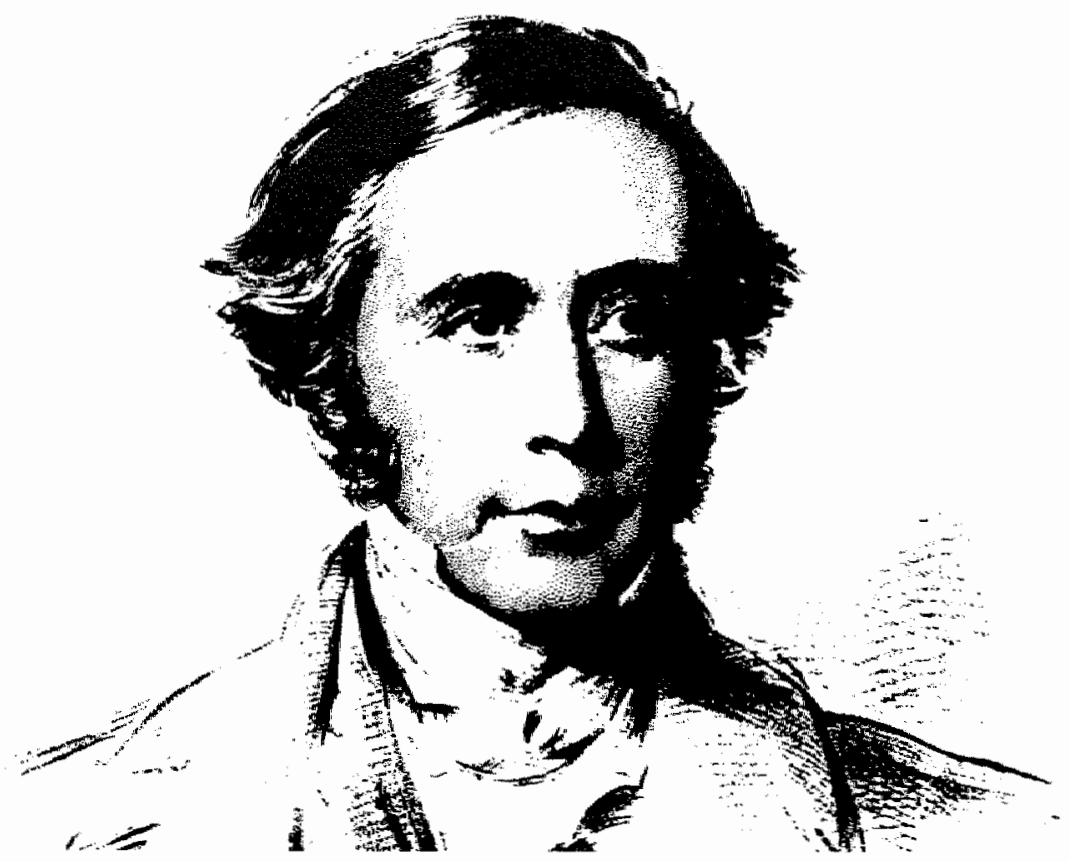

Fig. 22: James Syme (1799 - 1870).

Elke chirurgische ingreep, verricht $\| 1 / 2$ eeuw geleden, had het risico te eindigen met de dood van de patiënt. Zelden genas een wond per primam intentionem. Vaak kon de operateur niet meer bieden dan pus bonum et laudabile en genezing per secundam intentionem.

Toen in februari 1843 Syme's publicatie ,On amputation at the ankle joint" verscheen in de London and Edinburgh Monthly Journal of Medical Science (1843), was dit ruim 10 jaar voor Pasteur de medische wereld in opschudding bracht door de ontdekking van het bestaan der micro-organismen. Lister, de toekomstige schoonzoon van Syme, was op dat moment 16 jaar en pas in 1867 schreef hij over de behandeling van gecompliceerde fracturen, antiseptisch werkend middels carbolzuur. Vóór deze belangrijke ontdekkingen van Lister en Pasteur hadden Syme en zijn collegae rekening te houden met zeer harde feiten.

Bovenbeenamputatie was de standaard procedure voor gecompliceerde fracturen van het onderbeen. Nog was dan de mortaliteit $25 \%$ wanneer de 
beste operateurs de ingreep verrichtten. Een mortaliteit van $50 \%$ was meer regel dan uitzondering. De resultaten van een conservatieve behandeling van open fracturen waren nog bedroevender. De mortaliteil bedroeg dan $80 \%$ voor gecompliceerde femurfracturen, $50 \%$ voor de gecompliceerde fracturen van het onderbeen en $87 \%$ voor open voetwortelfracturen. (Harris 1970.) Ten aanzien van de laatstgenoemde fractuur schreef Syme (1848), vooropgesteld dat de patiënt in leven bleef: „The foot generally remains in such a state of stiffness, weakness and sensibility to external impressions as to be rather an encumbrance than a support to the patient".

In 1822 verbleef Syme enige tijd in Parijs en volgde hier als medisch student colleges van Lisfranc, waarbij operaties op een menselijk cadaver werden gedemonstreerd. Hier leerde Syme de operatie volgens Chopart kennen, welke hij 7 jaar later in Edinburgh introduceerde met goede resultaten. Deze intertarsale amputatie, of beter gezegd exarticulatie, werd door Chopart beschreven in 1783. (Fig. 23) De operatie volgens Chopart werd zelden gevolgd door postoperatieve complicaties, welke complicaties zo rampzalig bleken bij amputaties door het bot. Nu weten wij dat het succes van Chopart te danken was aan het feit dat de exarticulatie veel minder kans bood op sepsis vergeleken met een amputatie, waarbij mergholte en weke delen geopend worden. Syme en Chopart waren hierwan niet op de hoogte en de eerstgenoemde geeft het volgende commentaar: ,,The operation of Chopart, which only leaves the astragalus and os calcis, is the most valuable of all partial amputations as it commands the largest portion of the foot requiring removal for disease or injury, and at the same time preserves a support for the patient not less useful than that which is afforded by the whole of the tarsus ... I performed this operation in 1829, so far as I know for the first time in Edinburgh and have frequently done so since with the most satisfactory result . $\therefore$ ". (Syme 1964).

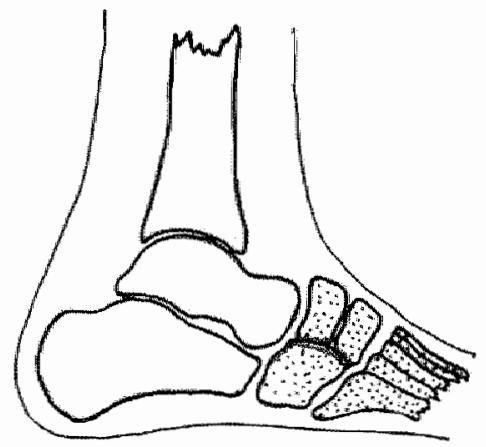

Fig. 23: Schema van amputatie valgens Chopart.

Wat te doen, wanneer talus dan wel calcaneus door trauma of caries (spreek uit tuberculose) waren getroffen en de amputatie volgens Chopart niet meer in aanmerking kwam. Dat Syme pas in 1842, 13 jaar na zijn eerste amputatie volgens Chopart, een exarticulatie verrichtte in het enkelgewricht wordt beter begrepen wanneer wij zijn probleem van de eindbelasting nader bezien. Exarticulatie in het enkelgewricht zou quo ad vitam net zo effectief zijn als de techniek van Chopart, maar de lange stomp zou de patiënt alleen 
maar tot last zijn wanneer hij er niet op kon gaan en staan. De amputatie door het bovenste spronggewricht was niet nieuw. Zonder succes was dit gedaan door diverse chirurgen. $\mathrm{Zij}$ bedekten de benige stomp met huidlappen, afkomstig wan de woetrug of de huid distaal van de malleoli. Zo was in 1842, éen jaar voor Syme's eerste publicatie verscheen door Baudens (1842) in Frankrijk de tibiotarsale amputatietechniek beschreven. Hierbij vond exarticulatie in het enkelgewricht plaats, gevolgd door verwijderen van de beide malleoli alsmede de dorsale helft van het tibiagewrichtsvlak. Het stompuiteinde werd bedekt door een huidlap, afkomstig van de voetrug, welke alle aanwezige weefselelementen bleef bevatten. Deze huidlap behoefde slechts losjes gefixeerd te worden, aangezien de lap als het ware zichzelf drapeerde over het stompuiteinde bij de te bed liggende patiënt. Postoperatief wondsecreet of haematoomvorming behoefde nauwelijks "een drainage. Toch bleek eindbelasting snel tot ulceratie te voeren.

Fig. 24: Schema van supra-malleolaire amputatie volgens Roux.

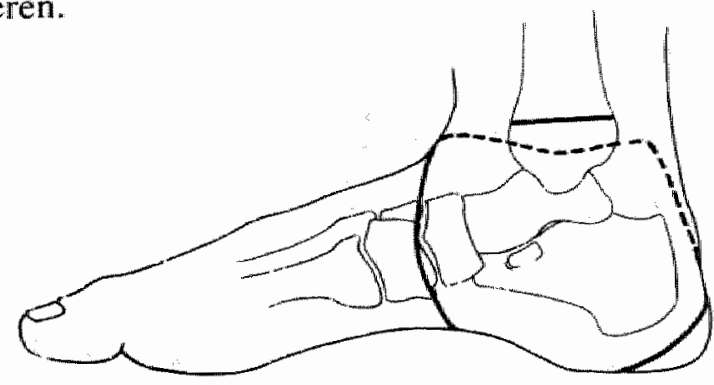

Roux (1846) amputeerde supramalleolair, waarna het stompuiteinde bedekt werd met een mediale huidlap. (Fig. 24) Ofschoon deze mediale huidlap gevoed werd door de arteria tibialis posterior, ontstonden ook hier snel complicaties bij eindbelasting. Het commentaar van Syme (1848) op deze operatietechnieken van Baudens en Roux luidde als volgt: , For my own part when I read of dissecting flaps of skin from the instep, or sides of the foot, I felt so much distrust in the protection that could just be effected against the injurious effects of pressure on a part so exposed to it, that I had no desire to try the experiment".

Men kan filosoferen over de reden waarom Syme wachtte met het daadwerkelijk uitvoeren van zijn operatietechniek, zoals wij die nu kennen. Het prepareren van een huidlap, welke daarna in een nieuwe positie geplaatst werd, was destijds een riskante zaak, want operatietechnieken met huidlappen gaven meer complicaties dan circulair verrichte amputaties, zoals Baudens en Roux moesten ervaren.

Mogelijk dat patiënten met andere chirurgische aandoeningen de aandacht van Syme opeisten. Tenslotte kan het zijn dat jaren nodig waren om Syme er van te overtuigen, dat een exarticulatie zoals Chopart deed, uiteindelijk veiliger was dan een amputatie door het bot, voordat hij het principe van Chopart durfde toepassen bij het bovenste spronggewricht, in die gevallen dat een operatie volgens Chopart niet meer mogelijk was.

Hoe dan ook. Syme (1843) beschrijft de nu,naar hem genoemde techniek als volgt: ,John Wood, aged 16, was admitted to the Royal Infirmary on the 8th of September 1842, suffering from disease of the foot which had suppurated and ulcerated in consequence of a twist he had given to it in walking about 
twelve months before. The instep was swollen and there were two openings discharging pus. A probe entered the sinuses freely into the substance of the tarsal bones, more particularly the astralagus and os calcis . . As the disease thad extended beyond the limits of Chopart's amputation it would have been necessary in accordance with ordinary practice to remove the leg below the knee, but as the ankle joint seemed sound II resolved to perform a disarticulation there. With this in view, I cut across the instep in a curved direction with the convexity toward the toes, and than across the sole of the foot so that the incisions were nearly opposite one another. The flaps thus formed were next separated from their subjacent connections which was easily effected except at the heel where the firmness of texture caused a little difficulty. The disarticulation being readily completed, the malleolar projections were removed by means of cutting pliers".

De voordelen van deze techniek, vergeleken met een onderbeenamputatie beschrijft Syme (1964):

,a. The risk of life will be smaller.

b. A more comfortable stump will be afforded.

c. The limb will be more seemly and useful for progressive motion".

Tussen 1843 en 1846 publiceerde Syme nog 4 artikelen omtrent deze operatie. Pas in 1857 volgt als laatste een ingezonden stuk in de Lancet als reactie op een zekere mister Ferguson, die in zijn boek ,,System of Practical Surgery" Syme's operatie ongunstig beoordeelde.

Syme antwoordt:

Sir,

Fifteen years ago I proposed a mode of affording relief from diseases that had been held to require amputation of the leg. by remowal of the foot at the ankle joint. This proposal was favourably received, and has long since been adopted by ind ligent surgeons at home and abroul as the established procedure in cases proper for its performance. It is casily executed and proves in the highest degree satisfactory, if done in accordance with certain principles whic th thave been carefully explained, but is difficult and disastrous if perfomed incorrectly". (Harris 1970.)

In 1854 publiceert Pirogoff zijn operatiemethode, welke hij als een verbetering van Syme's operatie beschouwt. (Dederich 1970, Harris 1970.) (Fig. 25)

In 1847 had Pirogoff te Heidelberg 2 patiënten gezien met een Symeamputatie en hij raakte onder de indruk van het resultaat. In de twee volgende jaren deed hij in Rusland deze operatie bij 5 patiënten. Zij overleefden dit niet. Desondanks ging Pirogoff door, zowel met de techniek van Syme als die van Baudens en Roux, met alleen als doel een onderbeenamputatie te voorkomen.

Pirogoff (1854) legt zijn ervaringen hiermede neer in de volgende conclusies:

1. Bij de techniek van Syme is het uiterst moeilijk de calcaneus te scheiden van de huidlap, zonder deze laatste in het ongerede te brengen. 


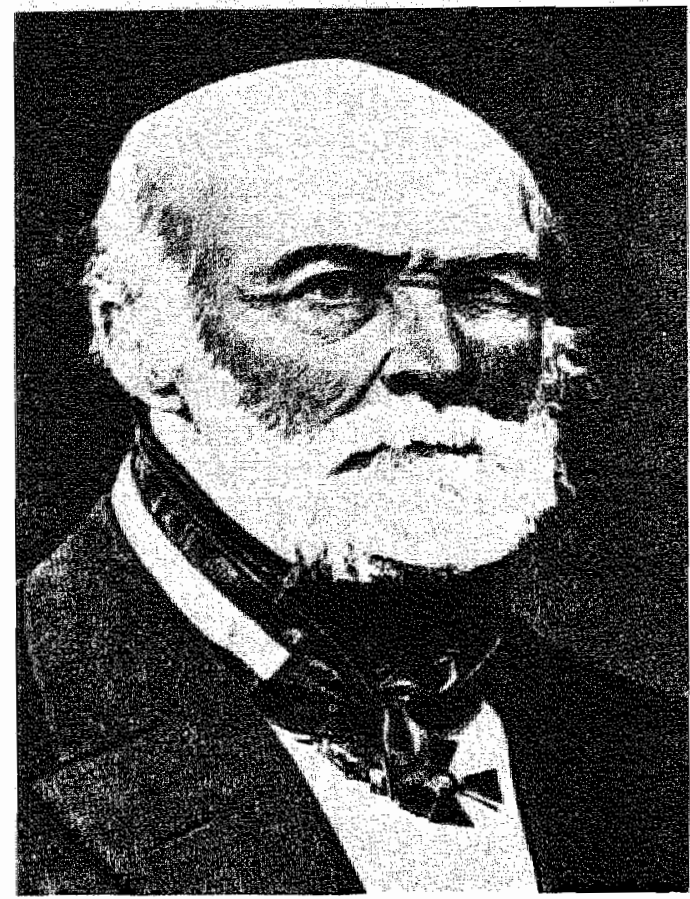

Fig. 25: Nicolai Ivanowitch Pirogoff (1810-1881).

2. De basis van deze lap bij de achillespees is dunner dan aan de apex. Bij onvolkomenheden in de techniek wordt zo de huidlap te dun of gangraeneus.

3. Door het verwijderen van de calcaneus ontstaat een pocket, waarin door onvoldoende drainage pus zich kan opstapelen.

4. Daarentegen staat bij de techniek volgens Baudens dat de plantaire stompbedekking niet zo stevig is als bij de operatie volgens Syme.

5. Ongetwijfeld is het maken van een posteromediale huidlap volgens Roux gemakkelijker dan de techniek volgens Syme. Maar ook hier is de basis van de huidlap smaller dan het distale uiteinde terwijl ook, evenals bij de technieken van Syme en Baudens, de achillespees volledig zijn vroegere insertie mist.

Op grond van deze overwegingen ontwierp Pirogoff zijn amputatiemethode. Deze verloopt aanvankelijk geheel volgens Syme. Pirogoff laat echter het dorsale derde deel van de calcaneus ongemoeid en daarmee de insertie van de achillespees. Zij maken samen deel uit van de voetzoolhuidlap. Ten dele blijft ook het gewrichtsvlak van de tibia bestaan. Enkele hechtingen fixeren de huidlap aan het onderbeen. (Fig. 26)

Indien de operatie zonder complicaties verliep, waren er ongetwijfeld voordelen vergeleken met de operatie volgens Syme. Consolidatie tussen calcaneusrest en tibia leverde een stomp op die langer was dan bij Syme en een prothese was in eerste instantie niet noodzakelijk, aangezien de optredende verkorting minimaal was.

De bottle neck van de operatie school echter in het regelmatig optreden van 


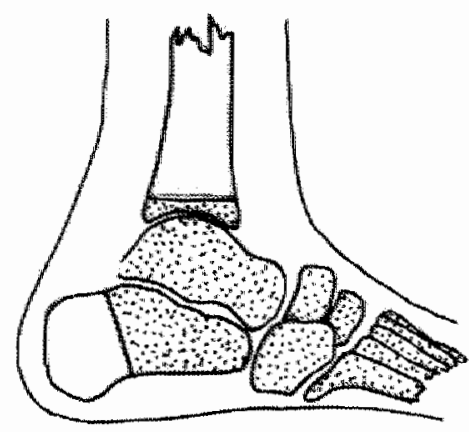

Fig. 26: Schema vart amputatie volgens Pirogoff.

een pseudarthrosis tussen calcaneus en tibia met een pijnlijke en niet belastbare stomp als resultaat. Bovendien werd niet de voetzool maar de dorsale hiellhuid belast, van nature niet geschikt hiervoor, met alle kwalijke gevolgen wanneer eindbelasting wordt toegepast. Tenslotte is bij dit minimaal verkorte been nagenoeg geen behoorlijke prothesevoorziening mogelijk.

Het gevolg hiervan is geweest dat naderhand diverse modificaties van de operatie volgens Pirogoff werden ontwikkeld. De belangrijkste van deze reeks modificaties zijn volgens Neff (1977) en Dederich (1970):

\section{Pirogoff-amputatie volgens Le Fort.}

Bij deze operatie worden talus en enkelvork gereseceerd. Craniaal en ventraal wordt de calcaneus zodanig gewigd dat hij zonder rotatie met 2 Kirschnerdraden op de osteotomieplaats van het onderbeen gefixeerd kan worden. Het terminale deel van de pees van de musculus tibialis anterior wordt gespleten en kan op deze manier de ventrale spongieuze wondvlakte bedekken. De pees wordt bevestigd aan de korte voetspieren en deze tenomyoplastiek zorgt later voor de mogelijkheid van isometrische spiercontracties, welke de circulatie in dit gebied ten goede komen. (Fig. 27)

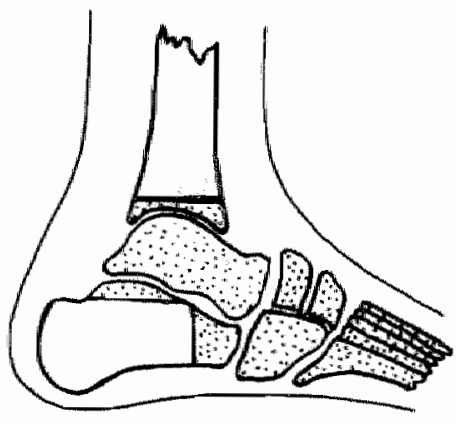

Fig. 27: Pirogoff-modificatie volgens Le Fort.

\section{Pirogoff-amputatie volgens Spitzy.}

Bij deze techniek blijft voor het grootste gedeelte de enkelvork behouden. De calcaneus wordt zodanig behandeld dat hij zonder moeite in de van kraakbeen ontdane enkelvork past, waarna het geheel met Kirschnerdraden wordt gefixeerd. De terminale stomp is hier ietwat volumineuzer doordat de enkelvork ten dele behouden blijft. (Fig. 28) 


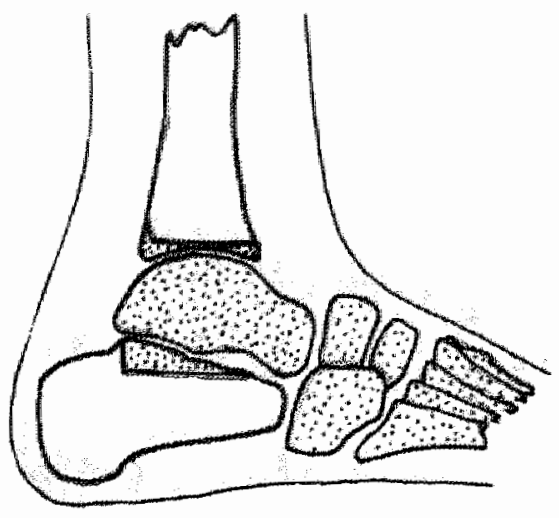

Fig. 28: Pirogoff-modificatie volgens Spitzy.

\section{Pirogoff-amputatie volgens Günther.}

Er wordt cen schuine osteotomie verricht van tibia en fibula alsmede van de calcaneus. Deze methode wordt bij voorkeur toegepast wanneer er sprake is van een spitsvoetstand, waardoor spanning op de achillespees wordt voorkomen. (Fig. 29)

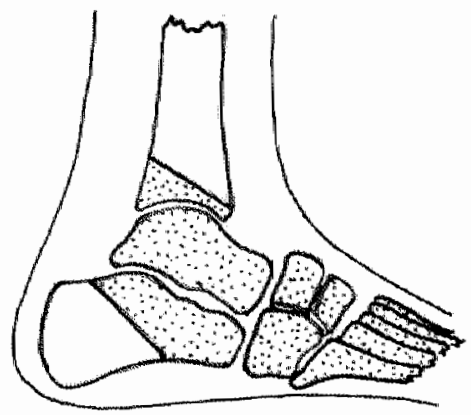

Fig. 29: Pirogoff-modificatie volgens Günther.

De modificaties van de originele Pirogofftechniek hebben alle het voordeel dat de huid van de voetzool belast wordt, dit in tegenstelling met de originele Pirogofftechniek. De bovengenoemde nadelen blijven echter bestaan.

Het grote antal operatietechnieken rond voetwortel en bovenste spronggewricht is enerzijds een gevolg van het feit dat de chirurgen destijds, de gevaarlijke amputatie door een onderbeen, een handbreedte onder de knie, wilden voorkomen. Anderzijds zochten zij in de $19 \mathrm{de}$ eeuw naar een methode waarbij eindbelasting mogelijk was, welke maar al te vaak niet gerealiseerd kon worden, omdat men niet op de hoogte was van de begrippen asepsis en sepsis. Dat het gemis aan goede anaesthesie het operatieresultaat ook kon beinvloeden, hoeft geen betoog.

Syme verbeterde zijn techniek. Uit zijn publicaties komt naar voren dat het bijzonder belangrijk is alleen gebruik te maken van zijn methode wanneer de arteria tibialis posterior intakt is, terwijl dit vat ook pas geligeerd mag worden na de splitsing in de plantaire vaten. Daarnaast is het niet deskundig verwijderen van de calcaneus een oorzaak voor wansucces, welke onder meer Pirogoff deed besiuiten een andere techniek te ontwikkelen. Zoals later zal 
blijken, is het subperiostaal verwijderen van de calcaneus de enige positieve bijdrage ter verbetering van de operatietechniek, zoals Syme deze beschreef.

Dat Syme's techniek in discrediet raakte vindt zijn oorzaak in onzorgvuldigheid van diverse auteurs. Na de Eerste Wereldoorlog verscheen in 1918 in Engeland een vertaling van het werk van 2 Franse chirurgen, Broca en Ducroquet (1918). Hierin wordt geen melding gemaakt van de operatie volgens Syme. Met betrekking tot de supramalleolaire amputatie vermeldt een voetnoot: ,In Engeland of course, this is allways called a Syme's amputation".

In 1924 verschijnt ,,Modern Operative Surgery". In het hoofdstuk amputa* ties beschrijft Elmslie (1924) een modificatie voor de operatie volgens Syme. Ondanks het respect dat Elmslie heeft voor de door Syme gevolgde techniek, schijnt hij niet begrepen te hebben hoe belangrijk voor het verkrijgen van een goed resultaat is het strikt volgen van de door Syme gegeven operatiedetails.

Elmslie heeft de volgende kritiek op Syme: de stomp is te lang en het uiteinde te dik. Mogelijk werd zijn gewijzigde operatietechniek geinspireerd door de kritiek van de toenmalige prothesebouwers, die moeilijkheden ondervonden bij het ontwerpen en realiseren van een prothese voor een Symeamputatiestomp.

De gewijzigde techniek van Elmslie komt hier op neer: (Fig. 30)

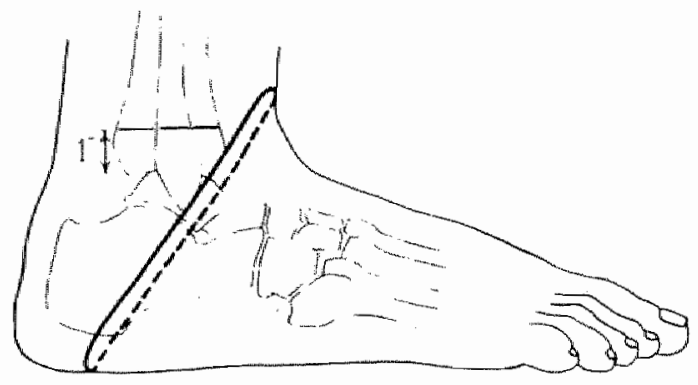

$\begin{aligned} \text { Fig. 30: } & \text { Supra-malleolaire } \\ & \text { amputatie } \\ & \text { volgens Elsmite. }\end{aligned}$

1. De voetzoolhuidlap wordt kleiner.

2. De tibia en fibula worden geamputeerd $3 / 4$ tot 1 inch boven de enkelvork.

Het doel was een taps toelopende amputatiestomp te verkrijgen, waardoor de prothese terminaal niet zo volumineus hoefde te worden, terwijl daarnaast het inbouwen mogelijk werd van een enkelmechanisme in de prothese. Deze modificatie van Elmslie was ook door Gyon in 1868 gepropageerd.

Gyon (1868) maakt gebruik van een elipswormige incisie, welke de calcaneus omsluit en frontaal het bovenste spronggewricht passeert. Zo blijft slechts een vingerbreed huid van de voetzool over. Een klein segment van de calcaneus blijft bewaard en wordt geplaatst tegen de supramalleolair geamputeerde tibia. (Fig. 31) Ook hier zijn de slechte resultaten van de operatie te wijten aan het, vergeleken met Syme's methodiek, in omvang geringere draagvlak van het bot.

Ook de resultaten van de techniek volgens Elmslie hebben de verwachtingen ervan niet overleefd en wel om 3 redenen: 


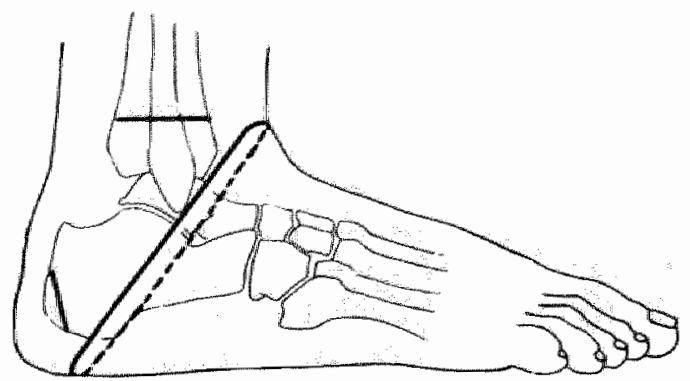

Fig. 31. Supra-malleolaire
amputatie volgens
Gyon.

1. Er is geen voldoende benig amputatie-uiteinde voor eindbelasting vergeleken met de techniek van Syme.

2. De nieuw gevormde huidlap is van nature niet geschikt voor eindbelasting.

3. De cosmetisch fraaiere prothese kan de taps toelopende stomp niet goed fixeren en tijdens het lopen schuift de prothese op en neer, waardoor extra huidirritatie wordt opgeroepen.

In de veertiger jaren wordt door chirurgen als Kirk (1942) en Vasconcelos (1945) eveneens de amputatie volgens Syme verkeerd geînterpreteerd. (Fig. 32 en 33)

Het commentaar op de operatie van Syme gegeven door Langdale-Kelham en Perkins (1942) van het Queen Mary's Hospital in Roehampton luidt in 1942 als volgt: "It is to be hoped that the modified Syme's amputation will soon be as obsolete as the original Syme"s." In tegenstelling tot dit ietwat vreemde commentaar, afkomstig van een zo belangrijk prothesecentrum als Roehampton, is het feit dat in Schotland en Canada, waar steeds de originele Symetechniek nauwgezet gevolgd werd, de resultaten wel bevredigend waren. (Harris 1970.)

Het Nederlands Leerboek der Orthopaedie, versehenen in 1977, noemt de operatie van Syme: ,Een amputatie direct proximaal van het enkelgewricht'. (Kingma, 1977.)

De nauwlettend toekijkende Netter, tekenaar van medische onderwerpen, laat keurig zien hoe het niet moet. (Fig. 34)

Ofschoon Syme zijn eerste publicatie noemt: ,On amputation at the ankle joint", verricht hij in feite een licht gemodificeerde exarticulatie. Juist de exarticulatie van Chopart deed immers Syme na jaren besluiten dit exarticulatieprincipe toe te passen bij het bovenste spronggewricht. Deze onzorgvuldigheid van Syme in zijn publicaties heeft er toe geleid dat ontelbaar vele supramalleolaire amputaties in naam van Syme zijn verricht , met als gevolg een klein draagvlak voor eindbelasting en daarmee een slecht operatieresultaat.

Dragen van het lichaamsgewicht alsmede het verplaatsen van dit gewicht. kort gezegd ,gaan en staan" zijn de essentiële functies van de onderste extremiteit. Deze functies dienen ook mogelijk te blijven na een beenamputatie. Eindbelasting na een amputatie van de onderste extremiteit benadert zoveel mogelijk de normale toestand, wanneer ofwel een knie-exarticulatie wordt verricht of een amputatie volgens Syme en dan precies zoals Syme deze amputatie in 1843 beschreef. 


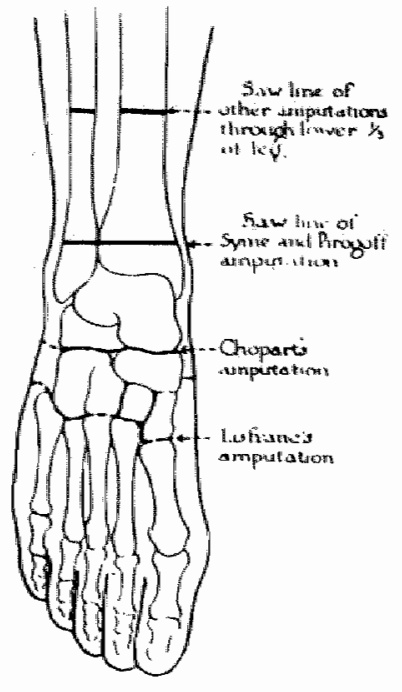

Fig. 32: „Syme-amputatie" volgens Kirk.

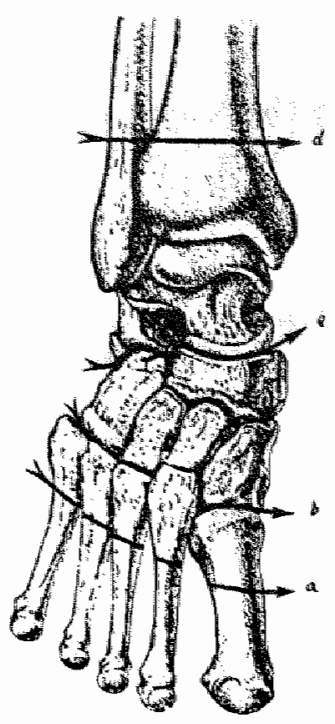

Fig. 33: "Syme-amputatie" volgens" Vasconcelos.

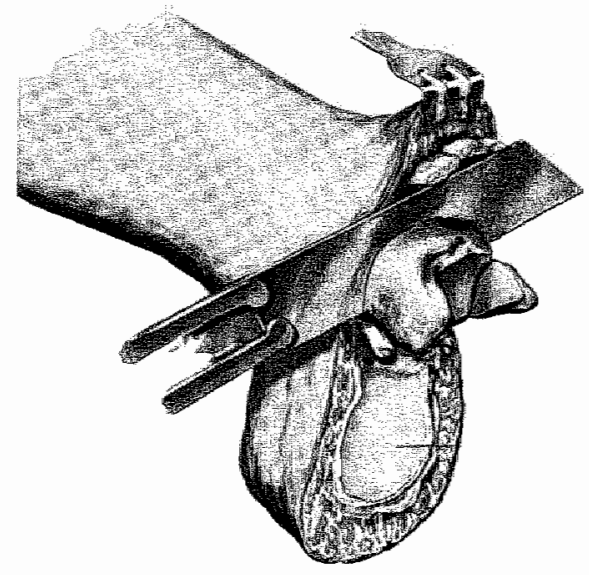

Fig. 34: "Syme-amputatie" geschetst door Netter. 
Zowel bij de knie-exarticulatie als bij de exarticulatie van Syme wordt gebruik gemaakt van een bedekkende huidlap, van nature geschikt om belast te worden, te weten kniehuid en voetzool. Daarnaast is zowel bij knie-exarticulatie als exarticulatie in het bovenste spronggewricht het benig draagwlak. zo groot mogelijk.

De structuur van de huid op bepaalde plaatsen in het menselijk lichaam, bedoeld voor belasting is onder meer beschreven door Tietze (1921). Deze structuur wordt, anders dan elders in de huid van het menselijk lichaam, gekenmerkt door grotere huiddikte, maar vooral door de aparte samenstelling van de subcutis.

Dit subcutane weefsel bestaat uit stevige septa van elastisch bindweefsel, welke ruimten omsluit gevuld met vetcellen. Elke zo gevormde loculus is volledig gescheiden van de ernaast liggende. In de voetzool strekken deze fibreuze septa zich uit van voetzoolhuid tot het periost van de calcaneus aan de dorsale zijde en de plantaire aponeurosis aan de ventrale zijde. Deze fibreuze laag met daartussen half vloeibaar vetweefsel, dient bij eindbelasting als een drukabsorberend kussen, waarvan wel de vorm maar niet de inhoud verandert. Belangrijk is bij de amputatie volgens Syme dit stootkussen ongemoeid te laten, waardoor de kwaliteiten van eindbelasting bewaard blijven. Dit is alleen dan het geval wanneer de calcaneus subperiostaal wordt vrijgeprepareerd. In het andere geval worden de septa geopend met lekkage van het half vloeibare vetweefsel. Dan verandert bij belasting niet alleen de vorm maar ook de inhoud en daarmee gaat de unieke huid- en subcutisstructuur voor eindbelasting verloren en herstel is niet meer mogelijk.

Bij de operatie volgens Syme houdt bovenstaande dus in dat, na exarticulatie van de voet in het enkelgewricht, subperiostaal de voetzoolhuidlap wordt geprepareerd. Daarna worden de malleoli verwijderd en het kraakbeen van de tibia in die mate dat, zoveel als mogelijk, de subchondrale corticalis bewaard blijft. (Harris 1956, 1970.) Het doel hiervan is om het vlak van eindbelasting zo maximaal mogelijk te houden. Speciaal zal er op gelet moeten worden dat dit benig draagvlak parallel loopt aan het horizontale vlak wanneer de patiënt staat. Dit betekent dat niet altijd het zaagvlak loodrecht op de tibia-as verloopt. (Fig. 35) De resulterende stomp moet knotsvormig eindigen om naderhand beter gevat te kunnen worden in een prothese. De voetzoolhuidlap oogt na prepareren plomp en slordig. Centraal, waar de calcaneus zich bevond, is de huidlap komvormig en aan de ventrale zijde dik, omdat zich hier de spierbuiken bevinden van de plantaire musculatuur. Instinktmatig zou menig chirurg nauwgezet deze plantaire musculatuur willen trimmen, maar er bestaat dan kans op beschadiging van de plantaire aponeurosis. Hierdoor wordt schade toegebracht aan de subcutane weefsellaag, waardoor de eindbelasting in gevaar komt. Het door Syme niet voorziene voordeel van het subperiostaal verwijderen van de calcaneus is gegeven in de betere fixatiemogelijkheid van de huidlap aan de stomp door het aanwezig blijven van het periost. Syme kende in zijn tijd niet de röntgendiagnostiek, welke pas op gang kwam in het laatste decennium van de 19de eeuw, waardoor bovenstaande geverifiëerd kon worden.

De huidlap wordt alleen gesloten op subcutaan- en op huidniveau, te 


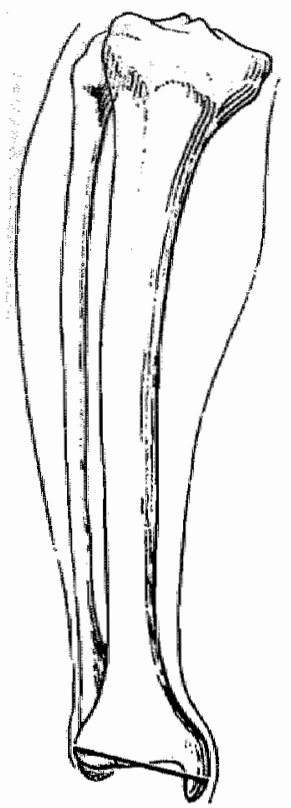

Fig. 35: Correcte zaagsnede bij Syme-exarticulatie, parallel aan horizontale vlak bij staande patiënt.

beginnen in het midden van de huidlap. Geadviseerd wordt de ",dogears" welke terzijde gaan ontstaan niet te reseceren, omdat hiermede de circulatie ter plaatse in gevaar komt. Drainage van het wondgebied vindt plaats zoals te doen gebruikelijk. Postoperatief worden de weke delen nauwkeurig gecentreerd onder het benige draagvlak en in deze positie gehand haafd door middel van een pleisterverband. Hier overheen wordt een licht drukkend verband aangelegd. (Goldberg 1973, Harris 1956, 1970).

Harris ( 1970) adviseert na 24 uur en daarna om de 2 dagen de positie van de weke delen te controleren en zonodig te corrigeren, zodat bot en weke delen niet asymmetrisch met elkaar kunnen vergroeien. Na 2 weken kunnen de hechtingen en het fixerend verband verwijderd worden. Belasting wordt pas 4 weken na de operatie toegestaan. Het moment voor prothesevoorziening is aangebroken 2 maanden na de operatie.

Deze prothesevoorziening met volledige eind belasting is echter alleen dan mogelijk wanneer de operatie correct volgens Syme werd uitgevoerd. Vandaar, mogelijk ten overvloede, nogmaals bronnen van fouten in de operatietechniek:

1. Onjuist geplaatste woetzoolhuidlap onder de benige stomp.

Dit kan voorkomen worden door postoperatief frequent te inspecteren en zonodig te corrigeren. Correctie door een hernieuwde operatieve ingreep heeft alleen zin als bij de primaire operatie de subcutane structuur van de voetzoolhuidlap niet werd beschadigd.

2. Het benige draagvlak loopt niet parallel aan het horizontale vlak.

Dan worden bij belasting de weke delen terzijde geschoven. Operatieve correctie is wel mogelijk, maar alleen ten koste van het benig draagvlak dat op hoger niveau geringer in omvang wordt. (Fig. 36 en 37) 


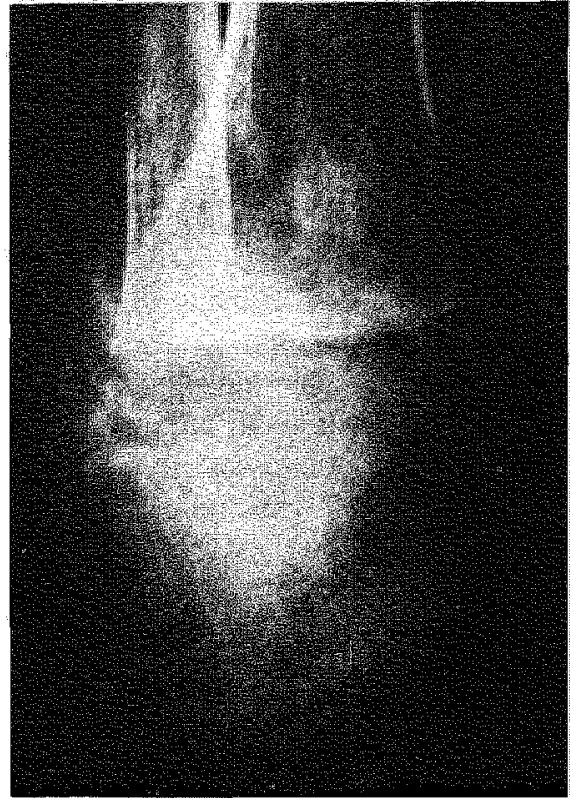

Fig. 36: Niet correcte zaagsnede bij Syme-exarticulatie.

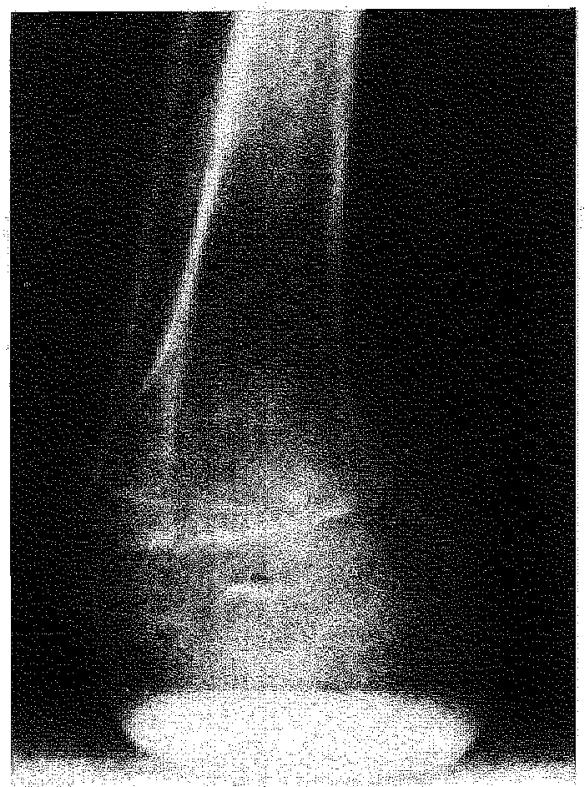

Fig. 37: De voetzoolhuidlap wijkt bij belasten naar opzij.

3. Instabiele huidlap.

Deze kan ontstaan wanneer de calcaneus niet subperiostaal verwijderd werd. Dan is er geen periost in de huidlap meer aanwezig dat stevig kan vergroeien met tibia en fibula. Ook hier is voorkomen beter dan genezen, want een operatieve correctie is uiteraard niet meer mogelijk. Een instabiele huidlap kan ook het gevolg zijn van te vroeg belasten. Alleen de prothesemaker kan dan door modificeren van de prothesefitting dit euvel nog zo goed mogelijk trachten te verhelpen.

4. Neuroom van de nervus tibialis posterior.

De nervus tibialis posterior kan op hetzelfde niveau doorsneden worden als de arteria tibialis posterior, na zijn splitsing in de mediale en laterale plantaire vaten. Klieven op een hoger niveau brengt gevaar van beschadiging der arteria tibialis posterior mee. De ervaring heeft geleerd dat een pijnlijk neuroom zelden ontstaat; mocht dit toch het geval zijn, dan wordt door Harris (1970) geadviseerd de zenuw te klieven op een niveau boven het enkelgewricht.

5. Marginaal gangreen van de huidlap.

Dit kan het gevolg zijn van een laesie van de arteria tibialis posterior of van zijn plantaire takken of een strak verband en te geringe controle. 


\section{De nu volgende casuïstiek van een drietal patiënten moge verduidelijken}

dat zowel de operatie volgens Syme alsmede de prothesevoorziening zeer exact dienen te geschieden, wil men een goed resultaat bereiken.

A. Een vrouw geboren in 1898 , werd in matart 1977 wegens prat-gangreen wan de linker voet in het ziekenhuis opgenomen. Bij haat was een lichte diabetes mellitus geconstateend. De status localis liet een sterk gezwollen linker voet zien met prae-gangreen van de tweede teen. Aortograthe leverde geen indicatie lot vasoreconstructic. De patiente werd conservatict behandeld. onder andere met antibiotica op geleide van de kweek der pus uit de tweede teen. Desondanks moest deze teen in april 1977 geamputeerd worden. Postoperatief kreeg zij steeds meer pijn an de linker voet. Veel necrotisch weefsel ontlaste zich uil de amputatiewond. Röngenologisch werden geen aanwijzingen gezien voor een osteomyelitis. Besloten werd tot een amputatie volgens Syme, welke op 10 mei 1977 verricht werd. Het postoperalicve beloop was nu ongestoord en begin juni, 3 weken later, begon men met belasten van het linker been. Bij opname in het Revalidatiecentrum zagen we een knotsvormig stompuiteinde met ventraal gelokaliseerd het amputatielitteken. Al in onbelaste toestand weken de weke delen natar laterat. terwijl dir bij belasten duidelijk toenam. Ook de röntgenfoto, onbelast en belast, liet dit verschil goed zien. (Fig. 38 en 39 ) We hebben gepoogd dit op te vangen met stevig orthopaedisch schoeisel. Aangezien patiente aan de rechter zijde een congenitale heupdysplasie had, hag hei voor de hand dat de looptraining mattig gedoseerd moest plats virden. 2 Matanden na opname kreeg de pattënte plotseling temperatur en de amputatiestomp was dtidelijk gezwollen. Voor de behandeling van dit abces werd de patiente weer in het ziekentuis opgenomen. Deze behandeling is niet gelukt en uiteindelijk werd een onderbeenamputatie noodzakelijk. In thet telefonisch overleg, voordat de patiënte vanwege de abcedering teruggeplatust werd natar het ziekenhuis. werd gesteld dat tijdens de Syme-amputatie de wondvakte goed doorbloed was. De vatag is, of hier door te vroeg belasten een instabiele huidlap ontstatan is welke nat lateratal afweek. Hierdoor zijn mogelijk de toevoerende bloed waten atan de mediale zijde afgekmeld, watardoor de circulatie marginaal werd en de abcedering een kans kon krijgen. De conclusiedtut hier een contra-indicatic atanwezig was om een Syme amputatie te verrichten is niet juist. Deze cusus latat zien dat de indicatie tot een Syme-amputatie goed was: de techniek per- of postoperatief was echter minder vallide.

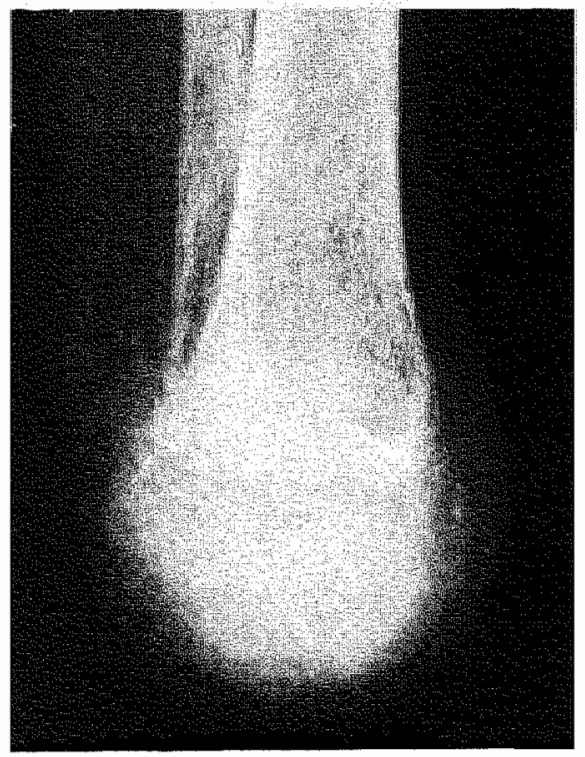

Fig. 38. Syme-exarticulatie in onbelaste toestand.

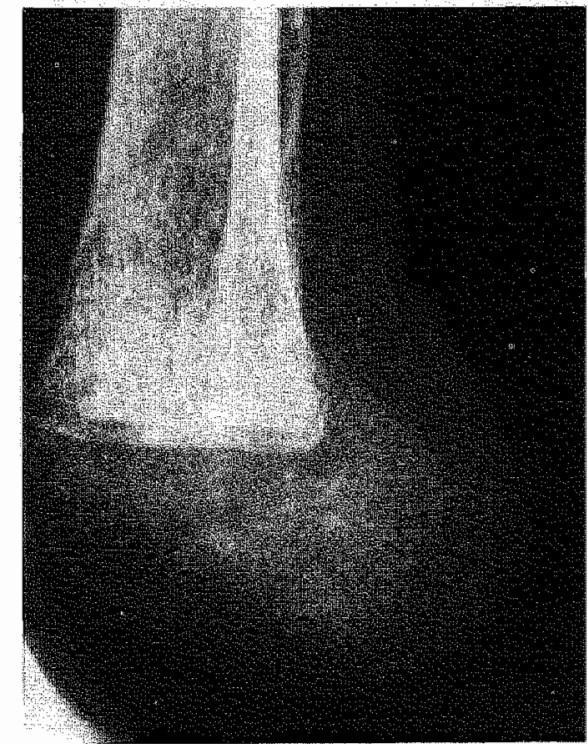

Fig. 39: Syme-exarticulatie in belaste toestand. 
B. Ten gevolge van een traurna werd bij een man, geboren in 1948, in 1971 een amputatie volgens. Syme ${ }^{*}$ van de rechter voet verricht. Prothesevoorziening wond daarna platis door een instrumentmaker elders. Deze maakte voor de man $2 x$ een prothese, maar hij was er nier tevreden over. Bij onde rzoek bleck dat het litteken aan de dorsale zijde gelokaliseerd was, terwijl de bestaande prothese voorzien was vaneen scharnierende achtertlap. Dit schamier bevond zich ter hoogte wan het litteken en veroorzakte hier duidelijk irritaties. Voor de man werd in de herfst 1975 in het Revalidatiecentrum Hoensbroeck een nicuwe prothese gemaakt, waarbij het dorsaal gelegen venster klemer van formaat was en niet scharnierend aan de prothese was bevestigd. Bovendien was de pasvorm rond het stompuiteinde nauwkeuriger. Het gevolg hiervan was dat. als eerste commentaar, de patient het aan-en uittrekken van de prothese moeilijker vond "maar eenmat aangetrokken veroorzaakte de prothese geen ongemak meer. Zijn verzoek on de prothese wat rumer te maken werd niet gehonoreerd. Na een maand was hij hieraan gewoon gerakk en sindsdien heeft hij bij poliklinische controle nooit meer een klacht geuit. De nieuwe prothese geeft geen enkele mogelijkheid meer tot op en neer schuiven rond de amputatiestomp. terwijl door het ontbreken wan een scharnier geen huidirritatie meer kan optreden. Een Symeamputatiestomp is dus zeker niet obsoleet te noemen, vooropgesteld dat ook de prothesemaker een technisch juiste prothese aflevert.

C. Een man geboren in 1924 liep in juli 1976 tijdens zijn werk als landbouwer een traumatische amputatie op van de rechter voet. Hij werd daarna diverse malen plastisch chirurgisch geopereerd. Bij onderzoek zagen we diverse littekens van een huidtransplantatie aan het onderbeen. De huid van het distale onderbeen was zeker niet optimaal te noemen. Bovendien was er bij deze ampulatie, hetgeen een amputatie volgens Syme bleek te zijin, nauwelijks sprake van een weke delen bedekking, maar letterlijk wan vel over been. (Fig. 40) Gezien dit gegeven zou een prothese, zoals bij een Syme-amputatie te doen gebruikelijk is, snel ulceratie van de huid oproepen. Vandaar dat de opwang gezocht moest worden in een total contact en een opvang volgens P.T.B.-principes zonder eindlbelasting. Hiermee bleek de man goed te kunnen functioneren. We kunnen zeggen dat hier .,An der Stelle der Not" geopereerd is: de patiënt voelde er echter totaal niets voor om. .An der Stelle der Wahl " een re-amputatie te ondergaan, nu de prothesemaker er in geslaagd was hem goed te laten functioneren met deze.,Syme-amputatiestomp". (Fig. 41)

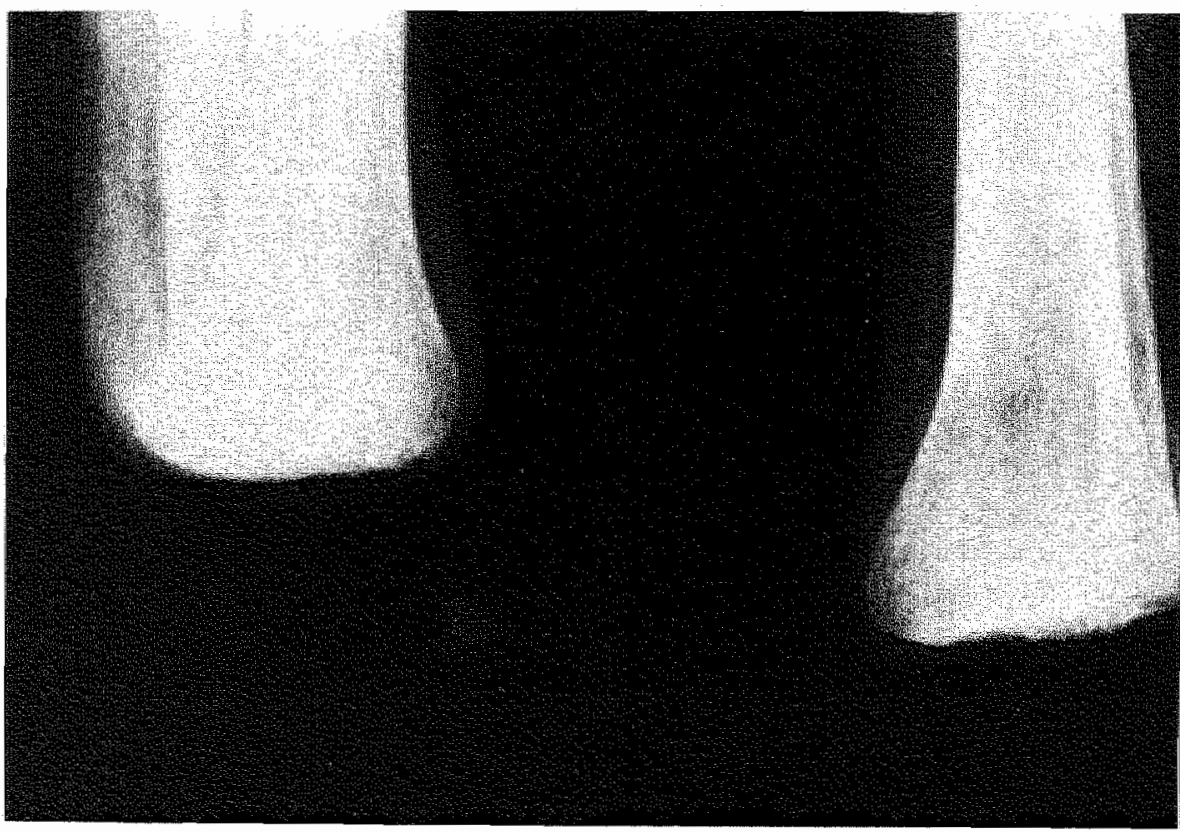

Fig. 40. "Syme-exarticulatie" zonder belastbare voetzoolhaidlap. 


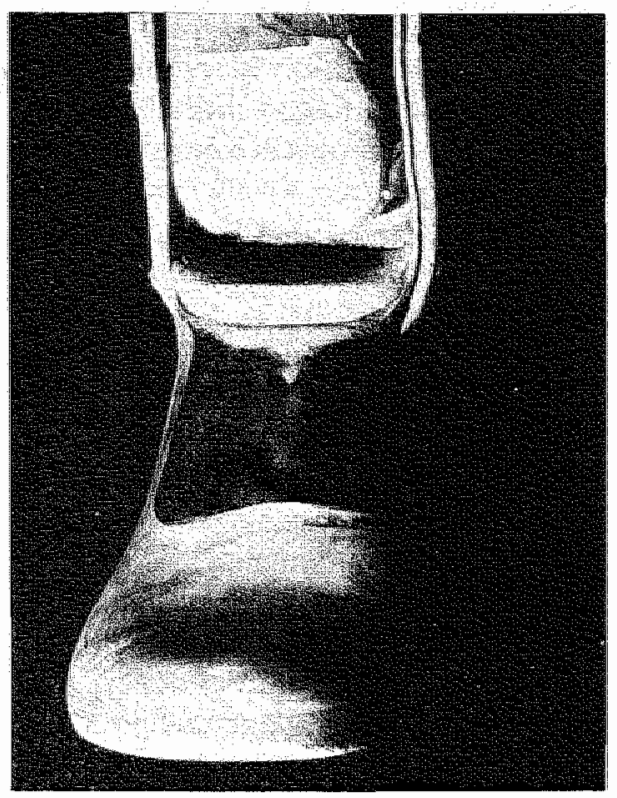

Fig. 41: Door P.T.B. -fitting wordt het stompuiteinde niet belast.

Deze casuistiek laat nogmaals zien, hoe belangrijk de verschillende schakels zijn in de behandelingsketen van geamputeerden, welke keten zo sterk is als de zwakste schakel.

Hornby en anderen (1975) onderzochten de mate van eindbelasting bij 68 geamputeerden volgens Syme, bij wie de amputatie het gevolg was van een trauma. De mate waarin eindbelasting optrad bij staan en lopen werd vastgelegd met behulp van een bepaalde fysische methode. De amputatie was bij alle patiënten correct uitgevoerd, terwijl ook op de prothesevoorziening niets aan te merken viel, 48 Patiënten bereikten een goed resultat, dat wil zeggen ten gevolge van de eindbelasting waren $\mathrm{zij}$ in staat volledig hun vroeger beroep te hervatten en zij waren niet beperkt in hun sociale contacten. 11 Patiënten werden als matig geclassificeerd. Zij waren in staat ten aanzien van de eindbelasting een minder zwaar beroep uit te oefenen dan voorheen, terwijl daarnaast de eindbelasting een beperking betekende wan hun sociale contacten. Bij 9 patiënten was het resulltaat slecht. Zij hadden constant pijn, met of zonder prothese, met of zonder eindbelasting, waren werkloos en zeer beperkt in hun sociale contacten. De mate waarin eindbelasting plaats vond volgens de meetmethode kwam overeen met deze drie genoemde groepen. Toch was er ten aanzien van de amputatietechniek en de prothesevoorziening geen verschil tussen de groep met een slecht resultaat en de 2 andere groepen. Bovendien bleek een poging om de eindbelasting via prothesecorrectie te verminderen geen beter resultaat op te leveren. De auteurs concluderen: ,Als groep waren deze 9 patiënten met een slecht resultaat moeilijk te taxeren. Het moreel was laag en zij oefenden kritiek uit op de hun toegekende restinvaliditeit”. Zij vervolgen: ,, Wij zijn niet in staat een verklaring te geven 
voor het feit waarom deze groep geen eindbelasting kan verdragen of warom verandering in de prothesebouw geen verlichting van hun klachten geeft. Terwijl het falen van een Syme-amputatie regelmatig toegeschreven wordt aan een insufficiente operatietechniek, was dit bij de bovengenoemde 68 patienten niet het geval".

De auteurs twijfelen niet aan individuele variaties in pijntolerantie, maar kunnen niet accepteren dat dit alléén een verklaring zou kunnen zijn voor het grote verschil bij deze 68 patiënten met technisch goed uitgevoerde amputaties volgens Syme. Men kan het volledig eens zijn met hun laatste conclusie, maar verschil in pijntolerantie is slechts een gering deelaspect bij een te revalideren patiënt. Nergens wordt bij dit onderzoek melding gemaakt van het feit dat ook bij geamputeerden revalidatie een leerproces is. Een leerproces dat uitgaat van de premisse: niet datgene wat de mens mist is belangrijk, maar de capaciteiten die hij overhoudt bepalen de toekomst.

Een technisch perfect uitgevoerde amputatie, een technisch perfect vervaardigde prothese geven nog geen garantie dat de patiënt ten aanzien van zijn handicap geen revalidatie, anders dan looptraining zou behoeven. Bij bovenvermeld onderzoek wordt geen gewag gemaakt van alle mogelijke psychosociale factoren, die het leren leven met een handicap belemmeren of verhinderen. Erkennen dat men een handicap heeft, is iets geheel anders dan ermee leren leven.

ledereen die nauw betrokken is bij de revalidatie van patiënten, ongeacht hun handicap, is overtuigd van de belangrijke rol die psycholoog en maatschappelijk werkende hierbij kunnen spelen. Wanneer, zoals bij bovengenoemd onderzoek, geen objectieve verklaring voor de pijn mogelijk is, zou men er toch rekening mee moeten houden dat deze pijnsensaties mogelijk van psychogene aard kunnen zijn, het gevolg van het niet kunnen accepteren en integreren van de handicap.

Pijn en pijntolerantie houden zo gezien verband met de instelling van de patiënt en zijn toegankelijk voor hulpverlening met name door psycholoog en maatschappelijk werkende.

De indicatie voor een amputatie volgens Syme is aanwezig wanneer een transmetatarsale amputatie of een amputatie volgens Lisfranc of Chopart niet meer mogelijk is.

Traumata, ernstige infecties gecompliceerd door chronische osteomyelitis en neurologische ziektebeelden zoals syringomyelie en lepra, kunnen, naast maligne aandoeningen, een indicatie voor een amputatie volgens Syme vormen.

Ofschoon in onze streken lepra nagenoeg niet meer voorkomt, is het, gezien bepaalde politieke ontwikkelingen, toch misschien interessant hierop in te gaan.

Een Syme-amputatie bij een lepra-lijder lost het probleem niet op, wanneer de resterende stomp ook anaesthetisch is en inhaerent hieraan een grote kans op ulceratie heeft. Afhankelijk van de uitbreiding van deze anaesthesie zou een onderbeenamputatie een goede oplossing kunnen zijn. Maar de meeste 
lepra-lijders wonen niet in gebieden, waar zij over een goed geoutilleerde orthopaedische werkplaats kunnen beschikken voor reparaties, correcties of eventueel vervangen van de prothese. Bovendien is deze anaesthesie bij de meeste lepra-patiënten zo uitgebreid, dat ook na een onderbeenamputatie het probleem van de gevoelloze stomp blijft bestaan. Amputatie op een hoger niveau heeft, naast het bovengenoemde bezwaar met betrekking tot een orthopaedische werkplaats het nadeel dat ook ulceratie en mutilatie van de handen vaak aanwezig is, hetgeen een goed gebruik van een bovenbeenprothese toch well ernstig belemmert. Door bittere ervaringen wijs geworden is menig lepra-patiënt toch in staat, door uiterste zorg aan de amputatiestomp te besteden na een Syme-amputatie, hiermede redelijk te functioneren. Immers, indien deze zorg en aandacht voor de stomp verwaarloosd wordt, wacht hem een amputatie op een hoger niveau, die de problemen alleen maar groter maakt. (Strinivasan 1973.)

De volgende casus moge deze problemen illustreren.

Een man, geboren in 1936, leed sinds 1964 aan de ziekte van Hansen, waardoor onder meer ulcera en progressieve sensibiliteitsstoringen ontstonden aan de rechter voet. In maart 1970 kwam hij vanuit Suriname naar Nederland, watar hij hoopte te genezen zonder dat amputatie noodzakelijk zou zijn. Wegens verdere uitbreiding moest in mei 1970 het rechter onderbeen geamputeerd worden. Inmiddels was ook de linker woet aangetast. Ook hier bracht langdurige conservatieve therapie met diaphenylsulforum geen verbetering en in november 1972 werd een amputatie volgens Syme aan de linker zijde verricht. De man kreeg elders 2 prothesen warmee hij tot fraai lopen kwam. Helaas ontstond aan het laterale stompuiteinde links een hardnekkig ulcus op basis van de ziekte van Hansen. Het gevolg hiervan was een regelmatig optredende inmobilisatie of hospitalisatie. Door de invaliditeit en een sociaal geissoleerd functioneren ont stonden problemen ten aanzien wan werk, ambulant zijn, de huisvesting en de verzorging. Vanuit thet ziekenhuis, waar dit alles plaatsvond, werd verzocht of het Revalidaticcentrum de gehele revalidatie ter hand kon nemen, nadat de stomp- of protheseproblemen waren opgelost.

De man had een prothese met eindbelasting en gezien de anaesthetische plek aan het distale stompuiteinde was hier de mogelijkheid gegeven tot het recidiverend ontstaan van ulcera.

In overleg met de orthopaedische werkplaats werd de bestande prothese verwangen door een gietharskoker wan kleine afmetingen, watdoor het stompuiteinde vrij in de schacht kwam te hangen, terwijl de koker gefit werd volgens de bekende P.T.B.-principes (Fig. 42) Hiermee kwam de man tot een goed looppatroon en het ulcus verdween, hoewel dit zeer langzaam gebeurde. Vanuit het Revalidatiecentrum werd ook voor de man werk verkregen alsmede huisvesting, aangezien hij de voorkeur eraan gaf in Zuid-Limburg te blijwen wonen.

$\mathrm{Na}$ ontslag bleek dat het laterale stompuiteinde toch regelmatig een zeer suspect uiterlijk toonde. In overleg met de huisarts en de patiënt werd dan ook besloten om tot een re-armputatie op onderbeenniveau ower te gawn; hiermee kon de patient zich volledig verenigen, aangezien hij ervaren had dat hij ook na onderbeenamputatie op dezelfde manier zou kunen lopen, heygeen voorheen de reden was dat hij zich sterk afwijzend ten opzichte van een amputatic op hoger niveat opstelde. Hij liep immers met een prothese. bedoeld woor een onderbeenamputatie. In mei 1974 werd elders een myoplastisch-myodetische amputatie vernicht, gevolgd door een immediate fitting. Met deze immediate fitting verliet patient lopend het ziekenthuis.

Nadat deze prothese te wijd was geworden. werd een mand later een P.T. H. prothese verstrekt. Zonder enige moeite kon hij hiermee lopen en desgev raagd gaf hij atan dat da amputatie op hoger niveau de loopfunctie subjectief zeker niet verslechterd had.

Ook voetdeformiteiten kunnen een indicatie vormen, zelfs op jeugdige leeftijd. Een kind, dat geboren wordt met een afwezige of hypoplastische fibula heeft al na een jaar, indien niet behandeld, een beduidende beenverkorting. Een verkorting van I $\mathrm{cm}$ op de leeftijd van 1 jaar betekent meestal een verkorting van $\pm 10 \mathrm{~cm}$ wanneer de groei is voltooid. (Davidson 1975.) 


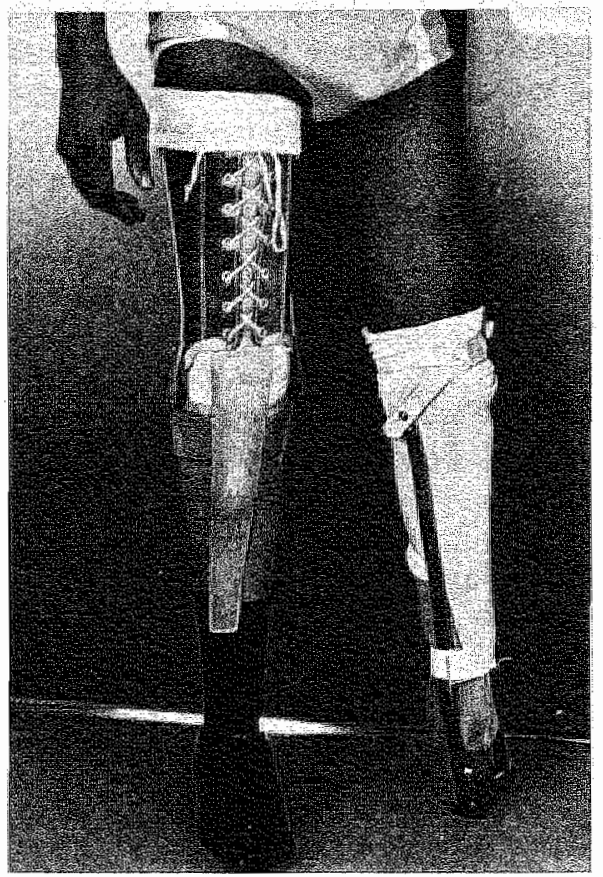

Fig. 42: Links: Provisorische

P.T.B.-belasting na

Syme-exarticulatie op basis

van $M$. Hansen.

Rechts: Conventionele

prothese bij

onderbeenamputatie, eveneens

t.g.v. lepra.

De hypoplasie van de fibula wordt bovendien meestal vergezeld door congenitale voetdeformiteiten, alsmede een instabiel enkelgewricht. Multipele operaties worden dan verricht om beenlengteverschil en instabiliteit van de enkel op te heffen. Desondanks is vaak nog cosmetisch niet fraai orthopaedisch schoeisel, al of niet gecombineerd met beugelapparatuur noodzakelijk om een redelijk looppatroon mogelijk te maken. Davidson (1975) deed bij deze congenitale afwijkingen een amputatie volgens Syme, waarbij de extensoren van de voet gehecht werden in de voetzoolhuidlap om migratie naar dorsaal te voorkomen. Daarna volgde een prothesevoorziening met partièel P.T.B.-opvang en partiele eindbelasting. De amputatie werd zo vroeg mogelijk verricht, dat wil zeggen op een tijdstip dat de prognose ten aanzien van de afwijking met zekerheid gesteld kon worden en het kind zelfstandig kon lopen. Het voordeel is dat het kind een aantal operaties en de daarmee gepaard gaande hospitalisatie bespaard blijven, terwijl het eindresultaat. cosmetisch gezien, fraaier is met een prothese dan met het abnormale schoeisel en beugelapparatuur.

Ook hier een illustratieve casus.

Een meisje. geboren in 1965. kwam op 9 jarige leeftid in september 1974 te vallen met alls gevolg een pürijike rechter enkel. Een röntgenfoto toonde geen bijzonderheden. Na enkele dagen steeg de temperatur tot $40^{\circ}$. Onder verdenking van osteomyelitis werd her kind in het ziekentuis opgenomen en verder lege art is behandeld. Wiar adan wankelijk geen röntgenologisehe afwijkingen te zien waren kon, eind ok taber 1974. de diagnose osteomyelitis gestek worden. Tenslotte gelukte hei dit proces min of meer tor stilstand te brengen. Desondanks nikkerde de afyclopen jaren deze osteomyelitis meerdere malen op. Vanaf 1975 dratge het meisje orthopaedisch schoeisel in verband met een beenlengteverschil ten nandele van links. De behandelend 
chirung werzocht opname in het Revalidatiecentrum in verband met algehele evaluatic. psychische begeleiding, vermagering en begeleiding ten anzien van het onderwils (VIA).

De bezinking bij opname alhier bedroeg $6 \mathrm{~mm}$ en bleef bij hertaling navenant. Hoewel ten gevolge van de vernietiging van de distale epiphysairschijf van het onderbeen door de osteomyelitis het rechter been korter was geworden, was dit in feite langer door de spitsvoetstand. die in het bovenste spronggewricht was opgetreden. (Fig. 43) De botstructur van nagenoeg de thele tibia en fibula is veranderd. Sclerosering van het skelet overweegt, met verspred min of meer vage ophelderingen. Distaal is supramalleolair een valgusstand in de tibia van $\pm 20^{\circ}$. Ter platse is ook een fibuladefect aanwezig. (Fig. 46) Het bovenste spronggewricht is wolledig geankyloseerd in een spitsvoetstand. (Fig. 45) Voor het meisje werd nieuw orthopaedisch schoeisel gemaakt. waardoor zowel subjectief als objectief het looppatroon verbeterde. Blift statn het cosmetische atspect van deze schoenen waarmee het meisje, dat nu haar puberteit is ingegan. toch wet moeilijkheden zou kunnen kriggen. (Fig. 44) Men kan overwegen of dan een amputatie volgens Syme verricht zou moeten worden, waarnat voor beide voeten weer nomal schoetsel mogelijk wordt.

Davidson (1975) en Arnold (1959) stellen dat bij het ziektebeeld „,congenitall abcense of the fibula" met de daarmee gepaard gaande ernstige verkorting van het been, een ventrale angulatie van de tibia, een equinovalgusstand van de voet en tenslotte het ontbreken van meerdere voetstralen, orthopaedisch schoeisel met de voet in equinusstand dan wel diverse typen van enkelarthrodesen inferieur waren aan de amputatie volgens Syme. Onder meer werd vaak een pijnlijke eindbelasting gezien. Door de verkorting van het been, zal bij een Syme-amputatie het knotsvormige stompuiteinde nagenoeg in het kuitdeel van de prothese komen te liggen, waardoor een cosmetisch acceptabele prothese mogelijk wordt. De discussie met betrekking tot de kans op opflikkering van de osteomyelitis bij elke operatieve ingreep is overigens nog niet gesloten bij de ziektegeschiedenis van bovengenoemde patiente.

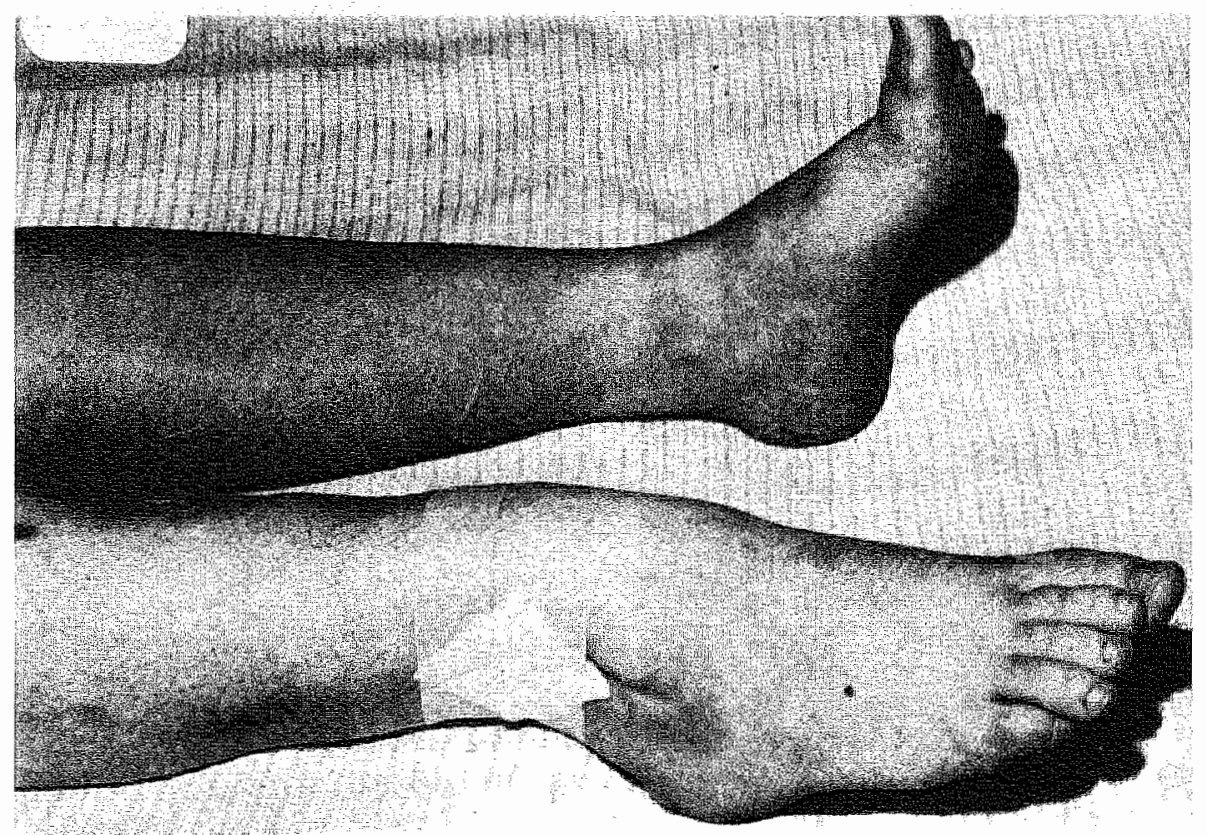

Fig. 43: Spitsvoetstand na osteomyelitis in het bovenste spronggewricht. 


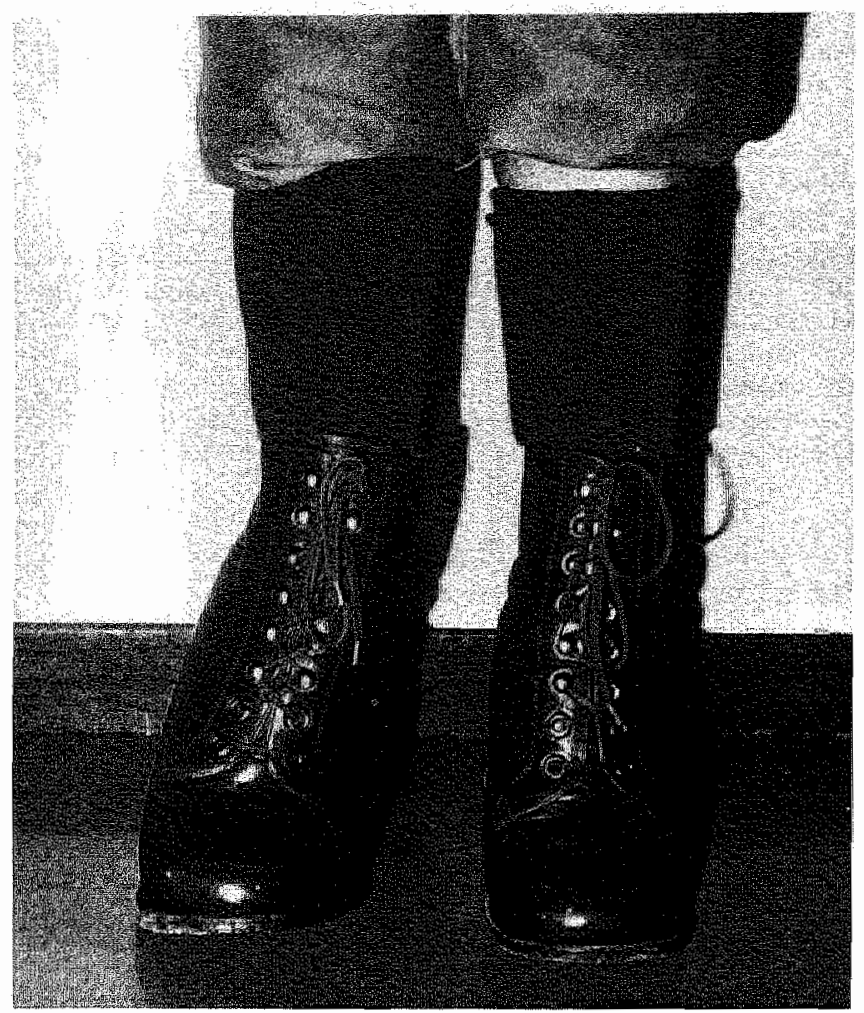

Fig. 44: Orthopaedisch schoeisel ter opvang van afwijking, genoemd in fig. 43.

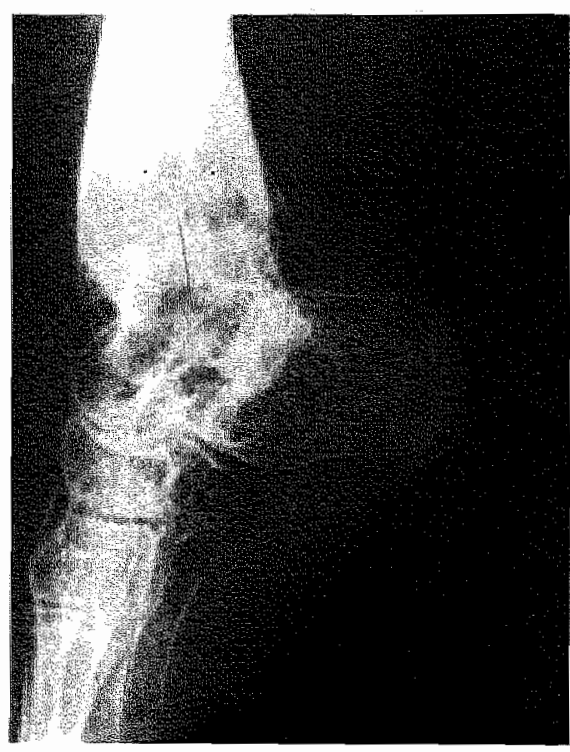

Fig. 45: Ankylose in spitsvoetstand.

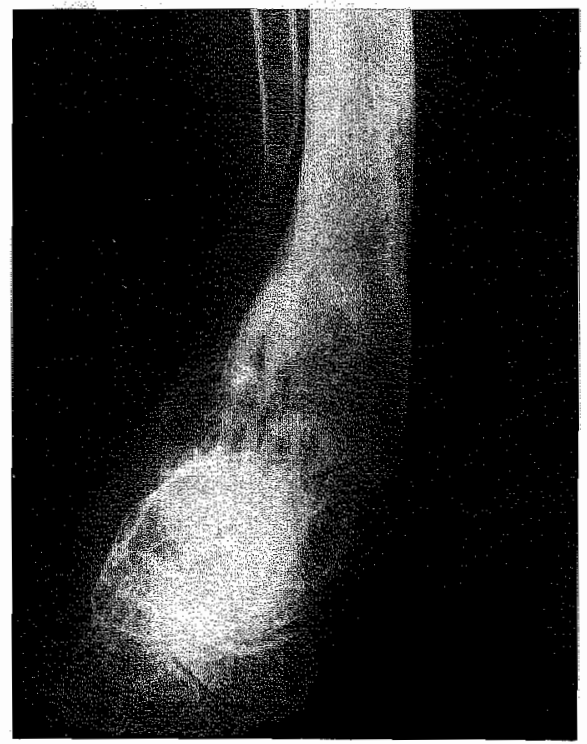

Fig. 46: Ankylose in bovenste spronggewricht en valgusstand in distale tibia. 
Vaatlijden als indicatie voor een amputatie volgens Syme moet apart vermeld worden.

Wanneer we strikt vasthouden aan de aanwijzigingen welke Syme gaf, zou een vaatlijden een contra-indicatie voor exarticulatie in het bovenste spronggewricht betekenen. Immers, Syme hecht bijzonder veel waarde aan een intakte arteria tibialis posterior evenals aan het intakt blijven van de plantaire vaten. Over het algemeen heerst ook in ons land de opvatting dat een Symeamputatie bij vaatlijden alleen maar de proloog is tot de voor de patiènt zo dramatische onderbeenamnutatie. Elders, en dan voornamelijk in Schotland en Canada wordt deze mening niet gedeeld. (Harris 1970, Goldberg 1973 en Gillis 1954.)

Harris heeft goede resultaten behaald zowel bij atherosclerosis als bij de ziekte van Buerger. De vraag is namelijk of de chirurgen, welke afwijzend staan tegenover een amputatie volgens Syme bij vaatlijden, bekend zijn met de correcte techniek.

Sinds 1843 is enige verwarring ontstaan omtrent de amputatie volgens Syme, welke in feite een licht gemodificeerde exarticulatie is met bijzondere aandacht voor de voetzoolhuidlap, zowel per- als postoperatief.

Men kan zich voorstellen dat bij opereren in weefsel met een marginale circulatie toch succes te behalen valt, wanneer alle kansen op mislukking consequent worden uitgesloten. Bezien in dit licht kan men de vraag stellen of vasculaire insufficiëntie een absolute contra-indicatie is voor een amputatie volgens Syme en of de slechte resultaten niet ten dele toegeschreven moeten worden aan een niet optimale techniek en postoperatieve verzorging.

Nog in 1977 wordt bericht uit Heidelberg, welke universiteit ter plaatse op het gebied van amputaties een wereldfaam heeft hoog te houden: ,,Mit der subcorticalen Kalkaneus-Ausschälung zur Erhaltung des Puffermechanismus der Fußsohle und zur abdeckelung der Tibia-Fibula-Osteotomiefläche haben wir noch keine eigene Erfahrung". (Neff 1977.)

Ook Sarmiento (1972) stelt dat, ondanks het unieke karakter van de eindbelasting volgens Syme, deze exarticulatie nergens ingang heeft gevonden. Hieraan zouden ebet zijn enerzijds de slechte resultaten wanneer de exarticulatie wordt toegepast bij vaatlijden, anderzijds het minder fraaie cosmetische aspect van de prothese.

Ten behoeve van dit cosmetische aspect voerde hij een modificatie in van de operatietechniek door $1 \mathrm{~cm}$ proximaal van het bovenste spronggewricht te amputeren, terwijl de beide malleoli nagenoeg volledig worden verwijderd. Uiteindelijk ontstaat er een amputatiestomp, welke nauwelijks groter in omvang is dan het dunste deel van het onderbeen. Dit is het uitgangspunt voor een nieuw prothesetype. Door gebruik te maken van schuimrubber net boven het iets dikkere stompuiteinde ontstaat een prothese, die het venster in de normaal te maken prothese na amputatie volgens Syme overbodig maakt. Dit komt zeker de cosmetiek ten goede. (Fig. 47)

Sarmiento propageerde de onderbeenamputatie bij vaatoperaties meer ingang te doen vinden ten koste van de ,zekere" bovenbeenamputatie. Met voorbijzien van de conditie van de grote beenvaten, afwezigheid van perifeer palpabele pulsaties, negatieve arteriografieën etc. werd de doorbloeding van huid en spieren ter hoogte van het amputatieniveau het belangrijkste crite- 
rium. Het succes dat Sarmiento hiermee ongetwijfeld behaalde, deed hem ook besluiten ditzelfde criterium bij de amputatie volgens Syme toe te passen.

Vanaf 1963 werden bij 53 patiënten zowel de gemodificeerde Symetechniek als de bovenbeschreven prothese gebruikt. $50 \%$ van deze patiënten ondergingen later op hoger niveau een re-amputatie. Sarmiento concludeert uit deze resultaten dat de Syme-techniek alleen toegepast mag worden bijeen doorgankelijke arteria tibialis posterior.

Dit lijkt toch een voorbarige conclusie en wel vanwege de volgende twee redenen. Bij amputatie door de tibia en fibula, ruim $1 \mathrm{~cm}$ boven het enkelgewricht, wordt zonder meer het benig draagvlak kleiner dan Syme bedoeld heeft. De grotere druk, welke de voetzoolhuidlap ten gevolge hiervan per vierkante centimeter moet doorstaan, mag men niet onderschatten, zeker niet wanneer het weefsel marginaal doorbloed wordt.

Een onderbeenprothese, niet voorzien van ventilatiemogelijkheden, vraagt om complicaties.

Ventilatie-openingen in de door Sarmiento ontworpen prothese doen afbreuk aan de functie van het schuimrubber, hetgeen juist bedoeld is om het op en neer schuiven van de taps toelopende stomp te voorkomen. Geen ventilatie betekent echter wel dat perspiratie en transpiratie gemakkelijk laceratie van de huid zullen oproepen, met alle gevolgen van dien bij marginaal doorbloed weefsel.

Ook Marquardt (pers. mededeling) is van mening dat een vaatlijden geen absolute contra-indicatie is om een exarticulatie volgens Syme te verrichten. Hij benadrukt eveneens de belangrijke per-en postoperatieve zorg. Als enige contra-indicatie ziet hij de ischaemische rustpijn.

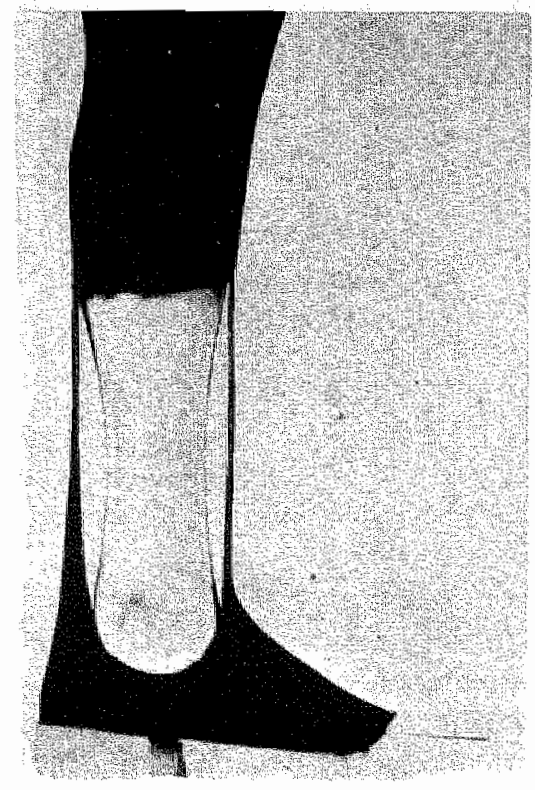

Fig. 47: Schema van prothese volgens Sarmiento na amputatie volgens „Syme”. 
Tenslotte is het mogelijk een Syme-amputatie in 2 tempi te doen zoals door Spittler (1954), Wagner (1977) en Burgess (1973) wordt verdedigd. Spittler en anderen (1954) stelden vast dat massieve infectie van de voorvoet ten gevolge van een trauma tot een amputatie op hoger niveau aanleiding gaf, wanneer primair een volledige Syme-amputatie werd verricht. Dezelfde ervaring had men opgedaan wanneer een Syme-amputatie in én tempo gedaan werd bij geïnfecteerde voeten van diabetici. Gezien de goede kwaliteiten van een gelukte Syme-amputatie werd in het Rancho Los Amigos Hospital te Californië een Syme-amputatiemethode in 2 tempi ontwikkeld. Aanvankelijk werd een $50 \%$ resultaat bereikt, zowel bij diabetici als bij vaatpatiënten. Door verfijning van de techniek en vooral door peroperatief van de "tourniquet bleeding reaction" gebruik te maken, later aangevuld door de Dopplermethode, steeg een positief operatieresultaat tot rond $95 \%$.

Bij amputaties welke niet voorafgegaan zijn door een recente vasoreconstructieve operatie wordt peroperatief de ,,tourniquet release bleeding reaction" gebruikt om een indruk te krijgen van de weefselcirculatie op het amputatieniveau. Als graadmeter dient een optredende bloeding, 3 minuten na losmaken van de tourniquet, aldus Wagner (1977).

Hij stelt dat sinds 1969 in bovengenoemd ziekenhuis ruim 300x deze Symemethodiek in 2 tempi toegepast werd met een gemiddeld succes in 70\% der gevallen. De leeftijd van de patiënten lag tussen 50 en 70 jaar. De indicaties voor deze operatie in 2 tempi waren:
a. de patiënt moet een potentiële prothesedrager zijn.
b. er mogen geen laesies zijn van de aan te wenden voetzoolhuidlap.
c. de systolische druk op enkelniveau, gemeten met de Dopplermethode moet minimaal $70 \mathrm{~mm} \mathrm{Hg}$ bedragen.
d. de verhouding tussen systolische druk aan de enkel vergeleken met de arm, gemeten volgens Doppler, hoort groter te zijn dan 0.45.
e. er mag geen ascenderende lymphangitis bestaan.
f. een infectie door gasvormende bacteriën moet afwezig zijn, vastgesteld door palpatie of door middel van een röntgenfoto.
g. een ,,tourniquet release bleeding reaction" hoort binnen 3 minuten op te treden.

\section{Eerste tempo.}

De incisie loopt parallel aan de klassieke incisie volgens Syme, maar is 1 tot $11 / 2 \mathrm{~cm}$ distaler gelokaliseerd. Verwijderen van malleoli en het kraakbeen van de tibia vindt niet plaats. Er wordt een spoeldrainagesysteem aangelegd ten behoeve van de gedurende 3 dagen toe te dienen antibiotica. De drain wordt uitgeleid via een incisie proximaal van de laterale malleolus. Bij verwijderen van de drain wordt opnieuw een kweek ingezet. De wond wordt, zoals gebruikelijk bij een Syme-exarticulatie gesloten, waarna een licht drukkend verband. Na 7 tot 10 dagen volgt het aanleggen van een gipsverband. Belasten wordt slechts bij uitzondering toegestaan. 


\section{Tweede tempo:}

$\mathrm{Na}$ ongeveer 6 weken volgt het verwijderen van de malleoli. Mediaal en lateraal worden incisies gemaakt over de dogears, waarna de beide malleoli worden verwijderd. Verwijderen wan het kraakbeen aan de onderzijde van de tibia vindt niet plaats. Wanneer na 7 tot 10 dagen de wond genezen is, krijgt de patient een loopgips. Meestal kan, 3 maanden na de eerste ingreep, prothesevoorziening plaatsvinden.

In alle opzichten, te weten snelheid, paslengte, cadans en zuurstofverbruik was deze groep patiënten de op hoger niveau geamputeerden verte de baas. (Wagner 1977, Burgess 1973.)

Het wekt toch op zijn minst enige bevreemding dat de techniek, zoals door Syme beschreven, zowel in zijn tijd als later, vaak zo onjuist werd geïnterpreteerd. Gyon-Roux-Elmslie en Pirogoff waren ervan overtuigd door hun modificaties betere operatieresultaten te verkrijgen. Hoe is het mogelijk dat in standaardwerken zoals van Kirk en Vasconselos dergelijke variaties van de Syme-techniek beschreven konden worden?

Dit is het gevolg van meerdere factoren.

Op de eerste plaats zijn de publicaties van Syme nogal vaag. Van hem werd gezegd: ,,He never wasted a drop of blood, never wasted a drop of ink and never wasted a word. (Harris 1970.)

Zijn publicaties laten slechts één en dan nog inadequate schets zien. (Fig. 48) We mogen echter niet vergeten dat primair Syme voor ogen stond: ,The risk of life will be smaller".

Toen decennia later de infectiekans als grootste probleem van Syme op de achtergrond raakte, lag het voor de hand dat menig chirurg probeerde de gevolgde techniek en de daaruit resulterende stomp te vervolmaken ten behoeve van een betere cosmetiek van stomp en prothese. Het staat zonder meer vast dat de toenmalige prothesemakers hierop hebben aangedrongen, waar dit ook nu nog steeds het geval is. Het is een zeldzaam voorbeeld in de geschiedenis van de chirurgie dat het rigoreus volgen van een operatietechniek, beschreven in een tijd waarin het begrip antisepsis zelfs onbekend was, zo watardevol bleek.

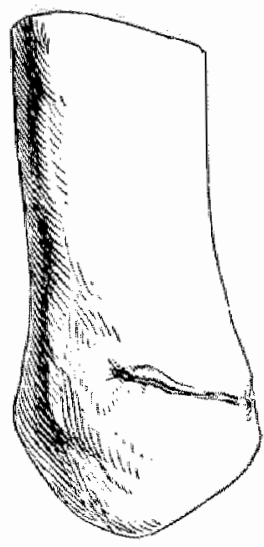

Fig. 48: Illustratie van Syme bij een van zijn artikelen. 
Nogmaals lijkt de slotzin uit de laatste publicatie van Syme op zijn plaats: ,The amputation is easily executed and proves in the highest degree satisfactory if done in accordance with certain principles which have been carefully explained, but is difficult and disastrous if performed incorrectly".

Zowel de exarticulatie volgens Syme, als het in het volgende hoofdstuk te beschrijven probleem van de knie-exarticulatie hebben in ons land, althans in de praktijk, niet de aandacht gekregen die andere landen hebben voor deze twee amputatieniveau"s.

Wanneer de berekeningen van het C.B.S.(1976) voor het jaar 2000 enige grond van waarheid bevatten, dan wordt het uitermate belangrijk ons te bezinnen op de problemen rond de amputatie bij de bejaarde mens.

De ,zekere" onderbeenamputatie en de vaak alleen op grond van een vaatonderzoek gestelde indicatie tot amputatie op bovenbeenniveau, geven rust aan de chirurg, die zeker is van een voorspoedige wondgenezing.

Dat deze rust en berusting pas veel later zijn bejaarde patiënt in het verpleeghuis ten deel vallen, moge voor elke operateur een reden zijn zich te bezinnen op zijn taak in deze. 


\section{De knie-exarticulatie.}

De knie-exarticulatie werd in de 18e eeuw beschreven. Dederich (1970) noemt Hildamus, Petit en vooral Brasdor, die in 1774 deze operatietechniek onder de aandacht bracht. Sindsdien heeft er in menig vaktijdschrift een polemiek plaats gevonden tussen voor-en tegenstanders van deze techniek.

Dederich (1970) geeft een opsomming van vooraanstaande chirurgen, die deze amputatie door het kniegewricht afwezen. Onder meer menen Lotsch, zur Verth, Böhm, Jottkowitz, Grasmann en von Renesse dat de exarticulatie door de knie: ,,einen ungünstigen Amputationsstumpf ergebe, dessen unteres Ende immer kolbig verdickt und hässlich sei".

Het gevolg hiervan is dat de protheseverzorging moeilijkheden oplevert. Er is geen plaats voor een protheseknie; alternatieve oplossingen zijn niet erg stabiel en geven de gebruiker alleen maar ongemak.

In Nederland heeft deze operatietechniek en dit amputatieniveau weinig aandacht gekregen.

Breslau (1956) vermeldt in 1956 op 732 beenamputaties slechts 17 knieexarticulaties $(2,3 \%)$. Een jaar later stelt Bär (1957) daarentegen: , De exarticulatie in de knie is zeer bruikbaar. Hiervoor kan men een prothese maken, die solide is, lang meegaat en waarop de patiënt zeer behoorlijk kan lopen, mede door de lange hefboomwerking van de lange stomp. De exarticulatie in de knie is van belang bij oudere mensen en bij belangrijke trauma"s, waarbij shock bestaat of kan ontstaan; immers het trauma van de exarticulatie is veel geringer dan dat van amputatie van het bovenbeen. Men krijgt dus een goed steunvlak voor de eindbelasting en wel met een bedekkende huid, die de druk goed kan verdragen".

Desondanks moet Bakker (1973) vaststellen dat op 935 amputaties van de onderste extremiteit, verricht in 1969 in geheel Nederland, slechts 5 knieexarticulaties $(0,5 \%)$ werden uitgevoerd. Mogelijk hangt dit samen met het feit dat de Nederlandse chirurg in het algemeen de afgelopen decennia weinig interesse toonde voor amputatietechnieken, een klein deelgebied van zijn werkzaamheden, echter met ver strekkende gevolgen voor de patiënt.

Zo werd enkele jaren geleden door het bestuur van de Nederlandse afdeling van I.S.P.O (International Society for Prosthetics and Orthotics) een bekend Nederlands chirurg uitgenodigd om een voordracht te houden over amputatietechnieken. In het antwoord, waarin de chirurg bericht niet in te kunnen gaan op de uitnodiging, wordt letterlijk gesteld: , Bovendien moet ik u zeggen 
dat het hoofdstuk amputatietechnieken mij nooit heeft gelegen, aangezien ik als chirurg een aversie heb van destructieve ingrepen".

Ofschoon deze stellingname niet de reden is geweest voor het schrijven van dit hoofdstuk, is het wel een goed uitgangspunt. In het tweede hoofdstuk werd getracht duidelijk te maken dat de operateur een essentiële plaats inneemt in de gehele revalidatieketen. Ook in andere hoofdstukken kwam dit telkens weer terug. Uit de volgende twee voórbeelden moge echter blijken dat het amputatieniveau, vastgesteld door de chirurg, niet altijd het resultaat is van een weloverwogen keuze.

Eind 1978 werd in het R.C.H. een patiënte opgenomen met de volgende ziektegeschiedenis.

Een 68 -jarige vrouw, sinds 25 jaar bekend met diabetes mellitus, wendde zich enkele maanden geleden tot een chirurg i.v.m. enkele kleine ulcera aan haar rechter voet. Deze werden deels conservatief behandeld, deels geattaqueerd middels necrotomieën. Genezing trad niet in.

Uiteindelijk werd bij deze patiënte, die alleen zeer distaal gelokaliseerde klachten had, een arteriografie verricht.

,De uitslag gaf een indicatie voor een bovenbeenamputatie rechts, een handbreed boven de knie."

Aldus geschiedde.

Een ander voorbeeld, waaruit blijkt hoe weinig een operateur op de hoogte kan zijn van moderne amputatietechnieken, blijkt uit het relaas van Reiner (1975):

,,Ein 17-jähriger Patient hatte sich bei einem Motorradunfall im August 1974 einen schweren offenen Oberschenkel- und Unterschenkelbruch links zugezogen, bei dem auch der Nervus ischiadicus verletzt worden war. Nach einem Erhaltungsversuch musste das Bein im Kniegelenk exartikuliert werden, weil der Oberschenkelbruch mit einem Marknagel versorgt worden war, der zum Zeitpunkt der Amputation noch im Oberschenkelmarkraum lag. Der operierende Chirurg plante nach festwerden des Oberschenkelbruches die Amputation proximal der Oberschenkelkondylen".

Meer oudere mensen dan vroeger ondergaan een amputatie op grond van vaatlijden. Revalidatie is bij bejaarden vaak een moeizame procedure, ondat andere manifestaties van het atherosclerotische proces belemmerend kunnen werken.

Ook in Engeland en Amerika heeft men, op grond van deze overweging, de laatste jaren weer belangstelling gekregen voor de exarticulatie door de knie bij arteriosclerotisch gangreen. (Newcombe 1972.)

Newcombe stelt, evenals Harding (1969), dat bij bejaarde mensen de standaard onderbeenamputie in rond $30 \%$ der gevallen een re-amputatie op bovenbeenniveau noodzakelijk zou maken, gezien de complicaties veroorzaakt door de vasculaire insufficiëntie. De meeste chirurgen prefereren dan een amputatie op bovenbeenniveau, wanneer er ook maar enige twijfel bestaat omtrent het te verwachten resultaat t.a.v. de wondgenezing. Men dient echter te bedenken dat na een bovenbeenamputatie, zeker wanneer deze niet wordt uitgevoerd volgens de moderne principes zoals onder meer door Karthaus (1973) en Dederich (1970) zijn beschreven, het gehele spierevenwicht 
verstoord dreigt te raken. Het gevolg van een dergelijke bovenbeenamputatie is dan ook dat, zeker de bejaarde patiënt, nooit een goed looppatroion zal bereiken. De vooral in de Eerste Wereldoorlog toegepaste amputatie volgens Gritti-Stokes is in principe een goed alternatief, vergeleken met de bovenbeenamputatie $12-15 \mathrm{~cm}$ boven het kniegewricht. Bij deze amputatiemethodiek worden de beide femurcondylen verwijderd, waarna de patella, na verwijdering van het kraakbeen aan de dorsale zijde, tegen het femuruiteinde wordt geplaatst.

De fixatie van de patella en aansluitend hieraan de consolidatie met het femuruiteinde is geen gemakkelijke zaak. Dederich (1970) adviseert de patella te fixeren middels 2 gekruiste Kirschnerdraden. Hij zegt: ,,Ebenso wichtig wie die Versorgung des Knochens ist aber beim Gritti-Stumpf die Herstellung funktionstüchtiger Muskelzüge".

Het niet juist fixeren van de patella aan het femuruiteinde, alsmede het niet correct behandelen van de resterende musculatuur na amputatie, is volgens Dederich (1970) vaak de reden geweest, waarom de amputatie volgens GrittiStokes niet voldeed aan de gestelde verwachtingen. De patella migreert ten gevolge van de tractie van de quadricepsmusculatuur en de stompvorm wordt konisch ten gevolge van de atrofie der bovenbeenspieren.

Deze amputatiestomp is dan niet meer geschikt voor eindbelasting; de patiënt heeft toch behoefte aan een tuberzit en hij is niet veel beter af dan na een gewone bovenbeenamputatie.

Knoche (1975) maakt melding van 6 patiënten, waarbij een vaatlijden de indicatie was tot een knie-exarticulatie, waarbij de operatietechniek volgens Baumgartner gebruikt werd. Baumgartner fixeert bij een tot $90^{\circ}$ geflecteerde knie de patella door middel van $2 \mathrm{AO}$-schroeven aan het femur. Het doel hiervan is te voorkomen dat de musculus quadriceps femoris tractie kan uitoefenen op de verbinding tussen het ligamentum patellae en de kruisbanden. Op te merken valt ook dat Baumgartner de incisie zodanig kiest dat het operatielitteken sagittaal verloopt, d.w.z. tussen de femurcondylen komt te liggen en dientengevolge buiten de belastingzône.

Knoche stelt dat de 6 bejaarde mensen de ingreep beter verdroegen, dan wanneer de amputatie verricht zou zijn door de femurdiaphyse. Bij de knieexarticulatie zijn alleen huid, subcutis, enkele ligamenten en de vaatzenuwstreng bij de amputatieprocedure betrokken. De gevolgen van een amputatie op hoger niveau door musculatuur en femurdiaphyse met het openen van de mergholte worden vermeden.

Oedeem in een amputatiestomp is bijna niet te vermijden als resultaat van de veranderde fysiologische verhoudingen, opgeroepen door de amputatie. Gebrek aan musculaire activiteit, inhaerent aan een langdurige bedlegerigheid bij een bejaarde patiënt, kan al het zogenaamde inactiviteitsoedeem veroorzaken.

Na een beenamputatie is de resterende stompmusculatuur zelden optimaal actief. De veneuze terugvloed in de extremiteiten, vooral wanneer deze moet gebeuren tegen de zwaartekracht in, hangt voor een groot deel af van de pompwerking der musculatuur. De doorsneden spieren ondergaan na een amputatie veranderingen, die deze veneuze spierpompwerking doen verminderen, zeker wanneer geen sprake is van correct behandelen van de muscu- 
latuur. Over de behandeling van resterende spieren na amputatie is zeer veel gepubliceerd. (Weiss 1960, 1973, Burgess 1971, 1973, Murdoch 1977. Dederich 1970, Karthaus 1973.)

De myodese en myofasciale plastiek heeft in de praktijk, zowel bij de eerste amputatie als bij een re-amputatie zijn nut bewezen. Door juiste behandeling van de musculatuur wordt de circulatie in de amputatiestomp verbeterd, hetgeen het functioneren met een prothese alleen maar ten goede kan komen.

Dederich (1970) maakte arteriogrammen vóór en ná een re-amputatie: , Die Vorteile der besseren Durchblutung des Stumpfes bei einer myoplastischen Operation lassen sich auch im Arteriogramm nachweisen. Man erkennt die schlechte Durchblutung des Stumpfspitzengebietes und den teilweise rückwärtsgerichteten Verlauf der Gefässe. Nach der Stumpfkorrektur (mit Knochenkürzung) erkennt man die wesentlich bessere Durchblutung des gesamten Stumpfes, weil die Stumpfmuskeln wieder funktionelle Arbeit leisten und mehr arteriellen Zufluss erhalten. Auch im Stumpfspitzengebiet sieht man jetzt dargestellte Gefässe ". (Fig. 49)
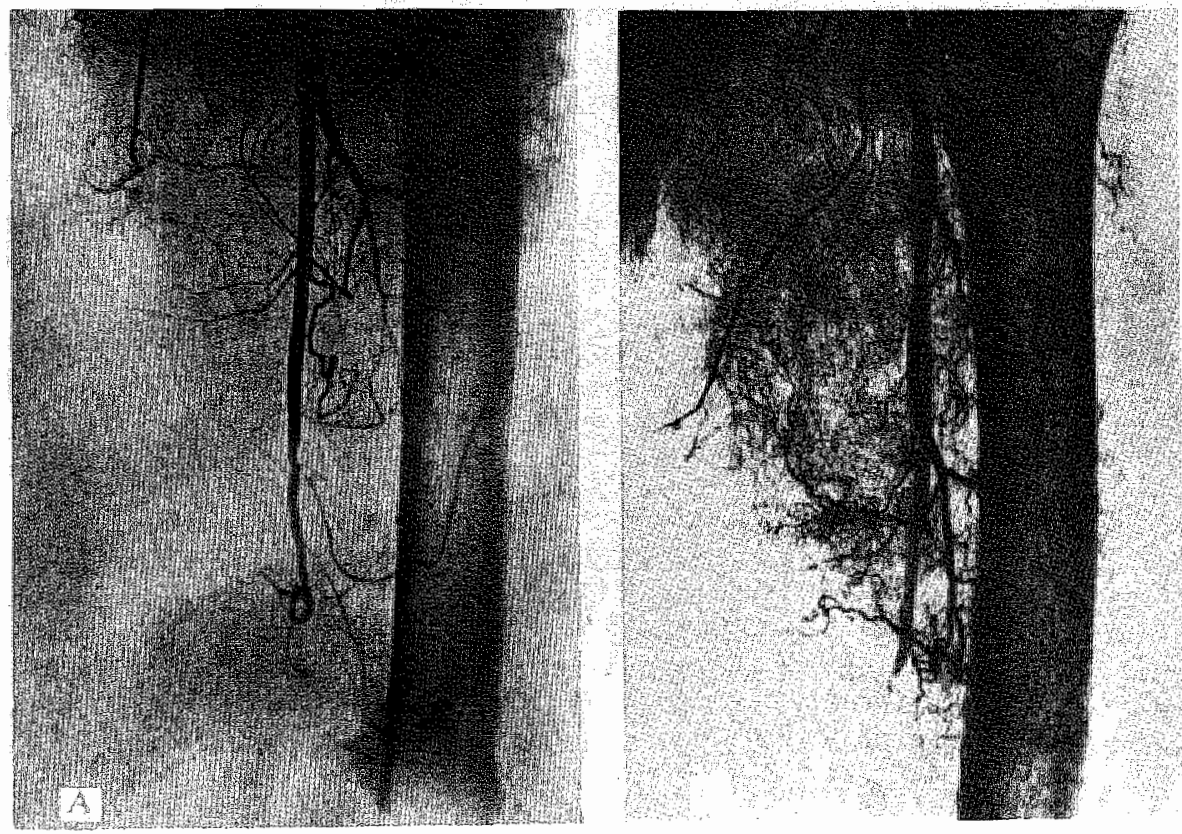

Fig. 49: Arteriogram a.) vóór en b.) ná myoplastische stompcorrectie.

Wanneer na amputatie de resterende musculatuur geen optimale behandeling ondergaat, wordt een barrière opgeworpen tegen een veneuze afvloed van bloed en weefselvocht, die door de amputatie ontstaat. Het hoeft geen betoog dat deze veneuze terugvloed bij een vaatlijden, al of niet gecombineerd met diabetes mellitus, al gestoord was door de lange bedlegerigheid van de patiënt.

Een amputatie waarbij de mergholte geopend wordt, heeft ook effect op de veneuze terugvloed binnen het bot. 
Loon (1960) injiceerde radio-opaque materiaal in de mergholte na amputatie door de femurdiaphyse. Daarna werden intraossale venogrammen gemaakt en vergeleken met het intraossale venogram van het niet geamputeerde been. Loon kwam, op grond van dit vergelijkend onderzoek, tot de volgende conclusie:

a. De intraossale veneuze afvloed is na amputatie significant trager geworden.

b. De intramedullaire sinus zijn gedilateerd en getordeerd.

c. Er blijven resten achter van radio-opaque materiaal.

d. Het diepe veneuze systeem wordt niet zichtbaar door radio-opaque materiaal.

Wanneer na amputatie de mergholte gesloten werd, b.v. door een periostlap, liet bovengenoemd onderzoek nagenoeg normale waarden zien. Loon concludeert hieruit dat:

a. een gesloten systeem kennelijk noodzakelijk is voor een normale intraossale druk.

b. een normaal druksysteem noodzakelijk is voor de normale intraossale veneuze drainage.

Hij adviseert dan ook, na de amputatie, de mergholte middels een botplug dan wel periostlap te sluiten. (Fig. 50)
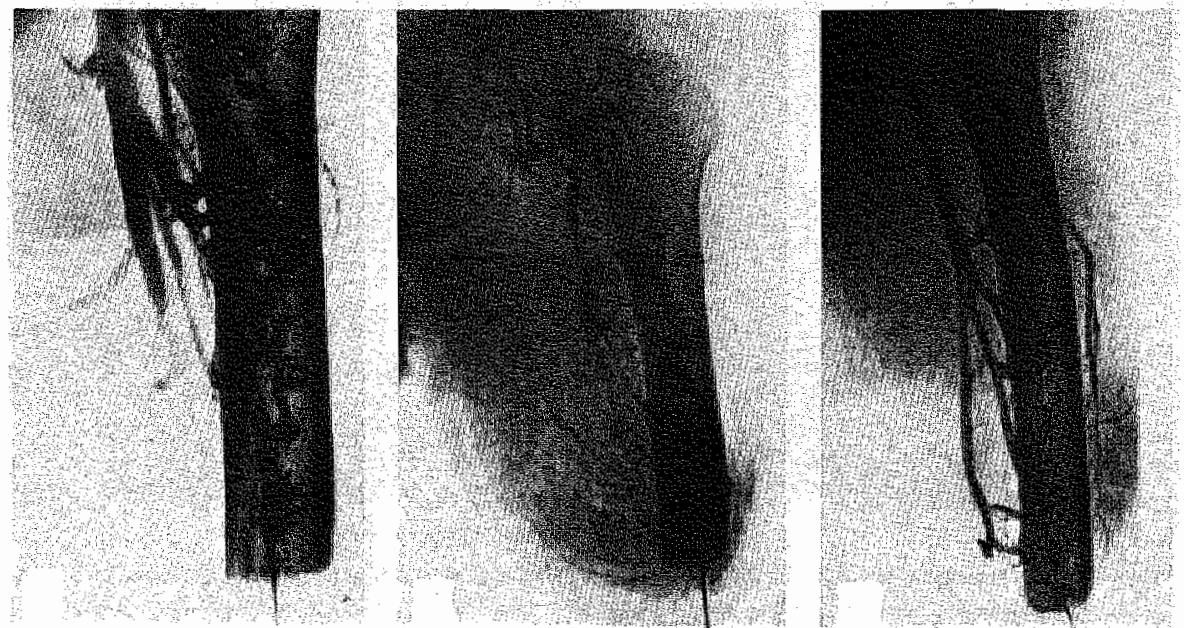

Fig. 50: Intra-ossale venogrammen na amputatie.

a. Bijeen niet osteoplastisch verzorgde stomp.

b. 3 maanden na osteoplastische en myoplastische stompverzarging.

c. 4 maanden na correcte verzorging van bot en weke delen.

Bij b. en c. wordt, in tegenstelling lot a., de contraststof terminaal al afgevoerd wia de distale vv. perforantes.

Er is slechts weinig contraststof proximaal aanwezig, nu in de gesloten merghoite een lichte overdruk aanwezig is. 
Ook Dederich $(1970,1973)$ is van mening dat het niet sluiten van de mergholte mede verantwoordelijk gesteld kan worden voor postoperatief optredende stomppijnen door de gestoorde veneuze afvloed en de daarmee op te roepen oedeemvorming. Karthaus (1973) stelt:, ,Bij vasculaire amputaties is het periost te dun om daarmee een goede mergholtesluiting te kunnen verkrijgen".

Overigens is hij van mening dat na myodese en myoplastiek een voldoende afsluiting van de mergholte wordt verkregen. Eenmaal zag Karthaus (1973) na overlijden van een van zijn patiënten bij obductie een stevige bindweefselplaat, welke de mergholte afsloot.

Het zal duidelijk zijn dat bij een knie-exarticulatie de problemen van gestoorde veneuze afvloed, het al of niet noodzakelijk zijn van het slluiten der mergholte, het correct behandelen van de musculatuur met inhaerent hieraan het al of niet achterwege blijven van oedeem en stomppijn, van geen belang zijn en eens te meer een argument vormen om in voorkomende gevallen een knie-exarticulatie te overwegen.

Dan rijzen de volgende vragen:

a. Wat zijn de voordelen van de knie-exarticulatie?

b. Wanneer is er een indicatie tot knie-exarticulatie?

c. Welke operatietechniek dient te worden toegepast?

\section{Ad. c. Operatietechniek}

Karthaus (1973), Dederich (1970), Jansen (1960), Murdoch (1967), Baumgartner (1978), Newcombe (1972) en Harding (1969) en vele anderen beschrijven uitgebreid de te volgen operatietechniek. De taak van de ,prosthetic surgeon" is, om in voorkomende gevallen met de operateur te overleggen, gezien de prothesevoorziening en revalidatie welke de patiënt nog resten na amputatie . Dan zou de boven beschreven 68-jarige vrouw, welke al een reeks van jaren leed aan diabetes mellitus, een amputatie op bovenbeenniveau bespaard zijn gebleven. Had een onderbeenamputatie al niet meer tot de mogelijkheden behoord, dan was een knie-exarticulatie te overwegen geweest. Harding schreef al in 1969: ,,Some years ago it was observed that a femoral or popliteal vascullar block leaves viable skin flaps long enough to cover the femoral condyles in a kneedisarticulation but too short for a below-kneeamputation".

\section{Ad. b. Indicatiestelling}

Murdoch (1967) stelt: De indicaties voor een bovenbeenamputatie hebben zich ontwikkeld: , against a background of crude and inaccurate methods of assessing tissue viability, 'conventional' amputation surgery performed by relatively junior surgeons, primary wound healing as the sole criterion of the success of the operation, and finally a total disregard for the patient "s needs".

De vergrijzing van de bevolking en het daarmee stijgend aantal amputaties 
heeft mede er toe bijgedragen dat in meerdere centra naarstig gezocht werd naar parameters om beter het meest distale amputatieniveau te kunnen bepallen. Murdoch (1977) komt tot de conclusie dat in een bepaald gebied van Schotland het percentage geamputeerden op grond van een vaatlijden $86 \%$ bedraagt.

Mazet e.a. (1959) zegt dat 20 jaar geleden ongeveer $90 \%$ van de bejaarde vaatpatiënten een bovenbeenamputatie ondergingen.

Momenteel kan men beschikken over arteriografie, metingen d.m.v. Dopplertechnieken, elektronische oscillografie, scintigrafie, thermografie, etc. om informatie te verkrijgen omtrent het te kiezen amputatieniveau.

Burgess (1971) stelt: ,W While the systolic bloodpressure in the limb and the results of thermography, Doppler bloodflow quantitation, radio-active isotope studies, and fluorescein photometry all may add information about the circulation of the limb, the condition of the skin at the level of the prospective amputation has proved to be the major guideline'.

Alle operateurs, met grote kennis van zaken op het terrein van de amputatieproblematiek, huldigen deze opvatting.

Vaucher (1978) zegt met betrekking tot de arteriografie: ,, Unsere Erfahrungen haben gezeigt, dass die arteriographische Untersuchung das genaue Amputationsniveau nicht bestimmen kann, denn das mikrovasculäre Netz, das sich auf den Röntgenfilmen nicht darstellt, ist manchmal in der Lage, die Gewebsversorgung auf einem distaleren Niveau zu ermöglichen. Wir haben daher verzichtet, die Arteriografie systematisch einzusetzen. Wir reservieren diese Methode für Patiënten, denen möglicherweise durch einen gefässchirurgische Eingriff geholfen werden könnte".

Vaucher is het echter niet volledig eens met Burgess. Hij stelt n.1:: ,,Das Ausmass der Blutung während der Operation gibt keinen sicheren Anhaltspunkt, da die heutigen gebräuchlichen Narkose- und Analgesietechniken manchmal doppelseitige chemisch bedingte Sympathektomien vortäuschen können".

Ook Murdoch (1977) is van mening dat aan arteriografie geen grote waarde moet worden toegekend, wanneer de vraag naar het amputatieniveau aan de orde is:

,The clinical appearances of the limb remain important providing information about peripheral pulses, frank gangrene or partial ischaemia and particularly the state of the skin. The surgeon need not be put off the lower levels of amputation by hairless, thin, inelastic skin, but he will certainly have doubts where there are frank ischaemic ulcers or a severe temperature drop is noted."

Hij stelt verder:, ,For a number of years a variety of ancillary methods of investigation have been available and all provide information of value although, even at this date, one cannot make categorical decisions on the basis of any single technique. In summary, the level of amputation selected, should be based on as much information as possible, bearing in mind the vallue of the knee joint in the rehabilitation of the patient and in the quality of his life there-after".

Burgess (197I) maakt melding van 193 amputaties, die op grond van vasculaire insufficiëntie verricht werden bij 177 patiënten. De gemiddelde leeftijd 
yan hen die leden aan diabetes mellitus was 65 jaar; de groep waarbij diabetes mellitus geen rol speelde was gemiddeld 61 jaar. 15 Patienten waren ouder dan 80 jaar. 4 Patiënten waren jonger dan 40 jaar. Met betrekking tot de arteriografie, wanneer deze verricht was, stelt Burgess: Analysis of the patients who' had arteriograms in this series demonstrated no consistent relationship between the severity of vascular insufficiency and the failure of a below-the-knee amputation to heal. Similarly there was no correlation between the demonstrated location of the obstruction and the failure to heal. This evidence supports Murdoch's assertion that arteriography demonstrates the true vascular picture at a disadvantage, and Warren's observation that arteriography demonstrates the pattern of collateral circulation but does not quantitate it. If arteriography had been used in this series for selecting the level of amputation many patients would have had above-the-knee amputations, yet in most of them (145, waarvan 2 bilateraal en 4 Syme-amputaties, waarvan 2 bilateraal) a satisfactory below-the-knee stump was obtained".

Ofschoon in Limburg in 1978 de tendens bestond meer op onderbeenniveau te amputeren, althans gezien de in dat jaar in het R.C.H. opgenomen patiènten, zijn de bovenvermelde citaten van Vaucher, Murdoch en Burgess nog zeker op zijn plaats. Nog te vaak wordt bij de overdracht van een patient vanuit het ziekenhuis naar het $R$.C.H. gesteld dat, gezien de arteriografische bevindingen, een bovenbeenamputatie geïndiceerd was.

Het toenemend aantal amputaties op grond van een vaatlijden maakt een citaat van Pedersen (1968) actueler dan ooit:, It is apparent that the current problem of the geriatric amputee is not primarily one of the prosthetic components, prosthetic design, fitting and alignment, or gait training. The current problem of the geriatric amputee is the preservation of the kneejoint".

Aangezien in de Limburgse ziekenhuizen van de bovenvermelde parameters alleen de arteriografie gebruikt wordt en misschien zeer sporadisch de andere mogelijke informatiebronnen om tot een betere beoordeling van het te kiezen amputatieniveau te komen, lijkt het juister meer de nadruk te leggen op de klinische bevindingen, zoals, gesteld door Burgess (1971) en Murdoch (1977).

Waar ook in Nederland rond $80 \%$ van de amputaties plaats vindt op basis van vasculaire insufficiëntie en het merendeel van deze groep bejaard is, moet de indicatie tot knie-exarticulatie gesteld worden als, ,preservation of the knee-joint" niet meer mogelijk is.

In het verleden werd wel gesteld dat de chirurg de knie-exarticulatie niet verrichtte, omdat hij door zulks te doen de prothesemaker voor onoplosbare problemen plaatste. Overigens was toen de chirurg maar al te vaak niet geïnteresseerd in het lot van zijn patiënt na goede wondgenezing.

Juist in Nederland was de knie-exarticulatie als zeer goed amputatieniveau nauwelijks bekend zoals de eerder genoemde percentages van Breslau (1956) en Bakker (1969) onomstotelijk aangaven. Degene die de cosmetiek van de knie-exarticulatieprothese aanvoert om dit amputatieniveau te negeren, zal er rekening mee moeten houden dat elke vaatpatiënt helaas kans maakt om het nog resterende been te moeten opofferen. Een combinatie van onder- 
beenamputatie en knie-exarticulatie geeft de patiënt nog een mogelijkheid om ambulant te worden. De kans hierop is bij een combinatie van onderbeenbovenbeenamputatie, zeker bij een bejaarde patiēnt, nauwelijks meer aanwezig.

De patient die in het ziekenhuis wacht op de beslissing van de chrirurg, wordt geobsedeerd door andere problemen dan het cosmetisch aspect van zijn toekomstige prothese. Voor hem geldt de alles overheersende vraag: „Is in de toekomst gaan en staan nog mogelijk?".

De chirurg is ook de man die de verantwoording draagt wanneer het gaat om heupcontracturen te voorkomen, die een contra-indicatie kunnen vormen tot knie-exarticulatie. De toch in elk ziekenhuis aanwezige fysiotherapeut dient na een vaatoperatie, waarvan het uiteindelijk resultaat nog niet bekend is, ingeschakeld te worden. Rekening houdend met de nog verse wonden moet hij in staat worden geacht het ontstaan van heupflexiecontracturen te voorkomen. Mutatis mutandis geldt dit ook voor de internist, die een patiënt met een ontregelde diabetes mellitus en met, tengevolge hiervan, aanwezige defecten aan de extremiteit behandelt. De internist dient zich te realiseren dat ook boven het bed van deze patiënt, als het zwaard van Damocles, de amputatie dreigend aanwezig is. De tijd, verlopend tussen opname van deze patiènt op de interne afdeling en de overname door de chirurg is vaak lang. Immers, de pijn van de patiënt bepaalt vaak het moment van de amputatie. Juist deze pijn veroorzaakt dan een bedlegerigheid, die heupcontracturen tot gevolg kan hebben.

\section{Ad. a. Voordelen van de knie-exarticulatie}

Breslau ( 1956) noemt als belangrijkste voordelen van de knie-exarticulatie:

1. ,Er ontstaat een groot, voor eindbelasting geschikt vlak.

2. De huid van de knie en het botuiteinde kunnen goed druk verdragen.

3. Er is een goede hefboomwerking.

4. Schouderbevestiging of bekkenbevestiging is niet noodzakelijk voor fixatie van de prothese.

5. De vascularisatie van het weefsel is goed, mits men de arteria poplitea afbindt beneden de plaats waar de arteria genu superior medialis en lateralis ontspringen.

6. Het trauma van de operatie is minder dan bij amputatie boven de knie".

Men kan hier nog aan toevoegen dat, tengevolge van het geringe operatietrauma en het nagenoeg achterwege blijven van postoperatieve oedeemvorming, de patiënt sneller gemobiliseerd kan worden vergeleken met een bovenbeengeamputeerde. Daarnaast heeft de lange stomp een betere mediaal-lateraalstabiliteit (doordat de bovenbeenmusculatuur volledig bewaard is gebleven), waardoor gaan en staan en het hierbij te bewaren evenwicht van groot belang zijn, zeker voor de bejaarde mens waarvan de visus al of niet tengevolge van een mogelijke diabetische retinopathie soms sterk achteruit gegaan is. 
Ook Baumann (1978) breekt een lans voor de knie-exarticulatie wanneer hij stelt:

, ,Nach der Knie-exartikulation ist eine wesentlich bessere Stabilisierung der Prothese am Stumpf gewährleistet als bei der Amputation in Oberschenkelschaft. Der lange Hebelarm, die Belastbarkeit des Stumpfendes und die Verminderung der Pseudarthrosenwirkung zwischen Stumpf und Prothese ermöglichen gute Gehsicherheit, weil die seitlichen Schwankungen des Prothesenschaftes am Stumpf weitgehend vermieden werden können?.

Tenslotte is het geringere gewicht van de prothese na knie-exarticulatie, vergeleken met een bovenbeenprothese eens te meer een argument om bij twijfel tussen een amputatie op onderbeen- dan wel bovenbeenniveau, aan de exarticulatie in het kniegewricht te denken. De chirurg dient rekening te houden met het toekomstig functioneren van zijn patiënt. Dit functioneren met een prothese hangt voor een niet gering deel af van de door de operateur gegeven stompkwaliteiten.

Overigens geldt dit laatste bijzonder voor kinderen en adolescenten, zoals in Hoofdstuk IV beschreven werd. Breslau (1956) zegt dat de knie-exarticulatie bij een kind een goede amputatie-keuze kan zijn: ,, omdat men de distale epiphysairlijn spaart en het bot dus normaal kan uitgroeien, hetgeen van groot belang is".

Dit is niet geheel juist. Baumgartner (1977) stelt: ,Gerade beim Kind hat aber die Exartikulation im Kniegelenk eminente Vorteile, die die Nachteile der durchaus möglichen, aber etwas unüblichen Protheseversorgung überwiegen". Hij noemt dan onder meer: „Die Epiphysenlinie am distalen Femurende, die zu $80 \%$ für das Längenwachstum verantwortlich sind, bleibt erhalten".

Desondanks treedt op de duur een verminderde lengtegroei op. Na exarticulatie in het kniegewricht op een leeftijd van 3 jaar, was, ondanks het behouden blijven van de groeischijf, op de leeftijd van 11 jaar al een groeiachterstand van $71 / 2 \mathrm{~cm}$ ontstaan. (Baumgartner 1977.) (Fig. 51)

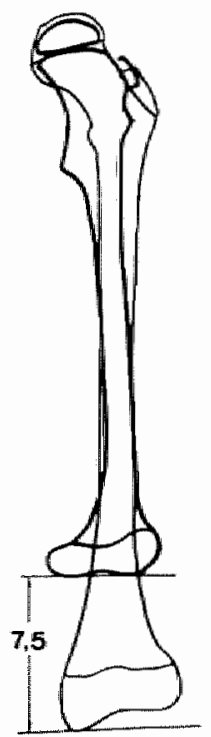

Fig. 51: Retardatie van lengtegroei in femur, 8 jaar na knie-exarticulatie op 3-jarige leefijd. 
Weiner (1978) geeft hiervoor een werklaring.

Intermitterende druk, optredend in een gewricht is een essentieel fysiologisch fenomeen. Deze intermitterende druk is niet alleen noodzakelijk voor een juiste diffusie van voedingsstoffen naar het kraakbenig gewrichtsoppervlak, maar ook belangrijk als prikkel voor epifhysairschijven met betrekking. tot hun bijdrage aan de lengtegroei van het bot. Weiner zegt., ,Retardation of longitudinal bone growth is almost an inevitable concomitant in limbs deprived of normal forces acting across a joint containing adjacent growth plates. In humans the forces delivered to articular joint surfaces and to epiphyseal growth plates are derived from muscle contraction, gravity, loading, or weightbearing".

Ten aanzien van maligne tumoren van de onderste extremiteit stell Murdoch (1977): "Much of the emphasis on chemotherapy is based on the view that the time interval between diagnosis of osteosarcoma and the appearance of lung metastases on radiological examination does not represent spread of the disease but rather the unveiling of the disease, which is already present".

Gezien dit gegeven, kan men zich afvragen of chirurgische therapie met betrekking tot de amputatie zo agressief moet zijn. Wanneer de patholooganatoom na onderzoek van een biopsie een osteosarcoom op onderbeenniveau vaststelt, betekent dit voor de patiënt meestal een amputatie transfemoraal. Knie-exarticulatie zou dan bij deze, meestal, jonge patiënten een goed alternatief kunnen zijn. Zowel gelet op de groeiproblemen, de betere mogelijkheden van prothesevoorziening, alsmede het beter functioneren, vooral, waar deze jonge mens nog een levensverwachting van tientallen jaren heeft, vooropgesteld dat de ziekte niet infaust verloopt. 9 Kinderen en adolescenten werden aan het R.C.H. overgedragen met een bovenbeenamputatie wegens een maligne tumor van het onderbeen. 5 Patiënten leven nog; bij twee van hen werd de amputatie langer dan 5 jaar geleden verricht.

Mazet (1966) wijzigde in 1966 de tot dan toe gangbare amputatietechnieken door een modelleren van de femurcondylen en het verwijderen van de patella, zodat het femuruiteinde met de omringende weke delen niet meer knotsvormig eindigt. (Fig. 52) Door het R.C.H. werd deze procedure, overigens niet op de hoogte van de modificatie volgens Mazet, in 1973 en later toegepast in overleg met de chirurg. Ook Burgess past, volgens Mazet (1978) deze modificatie toe.

Ook onder de chirurgen, die de waarde yan de knie-exarticulatie onderkennen als keuzemogelijkheid, is er nog een controverse, gelegen in de moeilijkheden bij de prothesevoorziening. De biomechanische voordelen, ontstaan uit de bij de knie-exarticulatie gegeven eindbelasting, gaan de mogelijkheden van een amputatie op bovenbeeniveau verre te boven.

Deze problemen bij de prothesevoorziening zijn:

a. Het gemis aan ruimte onder het stompuiteinde, nodig voor het inbouwen van een conventionele dan wel een blokkerende knie.

b. De brede femurcondylen, welke de cosmetiek van de prothese geweld aandoen.

Bij de conventionele knie-exarticulatie, waarbij femurcondylen en patella 


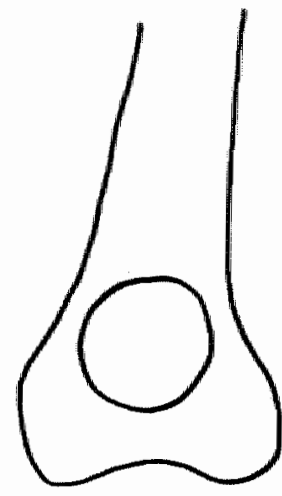

KNIE-EXARTIKULATION

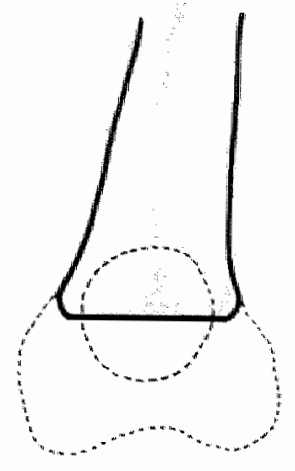

SLOCUM

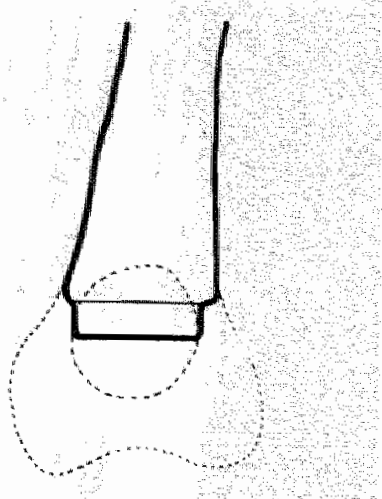

GRITTI
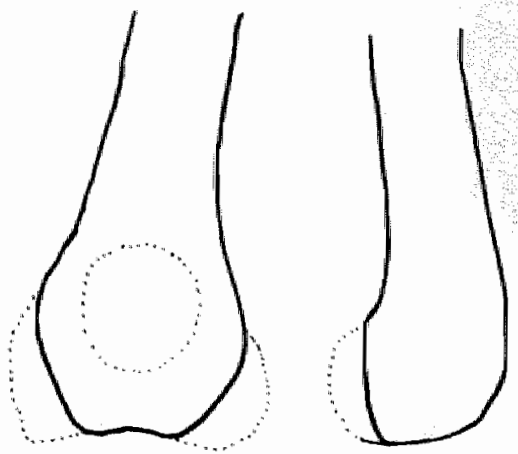

Fig. 52: Conventionele knie-exarticulatie en diverse modificaties.

MAZET

intact worden gelaten, vereist de vorm van de stomp het gebruik van een lederen koker met een ventrale veterbandsluiting of een gietharskoker met een partieel flexibel dan wel open gedeelte boven het supracond ylaire gebied, om het stompuiteinde dit nauwe gebied te kunnen laten passeren. De lederen koker heeft als nadeel dat de flexibiliteit ervan niet altijd constant blijft, terwijl correctie van deze flexibiliteit middels veterband de atrofie van de bovenbeenmusculatuur in de hand werkt. De harde gietharskoker wint aan populariteit, mede vanwege de hygiënische voordelen welke dit materiaal biedt. Het vervaardigen ervan vooronderstelt well grote ervaring, wil de pasvorm uiteindelijk niet te wensen overlaten.

Welke prothese-uitvoering men ook kiest, het cosmetisch aspect is niet fraai en met name vrouwen zijn er niet enthousiast over. (Fig. 53) Door de modificatie, zoals beschreven door Mazet (1966), toe te passen wordt de stomp min of meer konisch waardoor niet alleen het cosmetisch aspect aanzienlijk verbetert, maar ook het toepassen van een zuigkoker mogelijk wordt, waardoor andere bevestigingsmechanismen zoals bekkengordel of schouderbandage overbodig worden. Een nadeel van de modificatie van Mazet is gelegen in het feit dat bij niet gelukken van een zuigkoker, een kokertype met bandage gemaakt moet worden. Immers, dan kan de fitting 


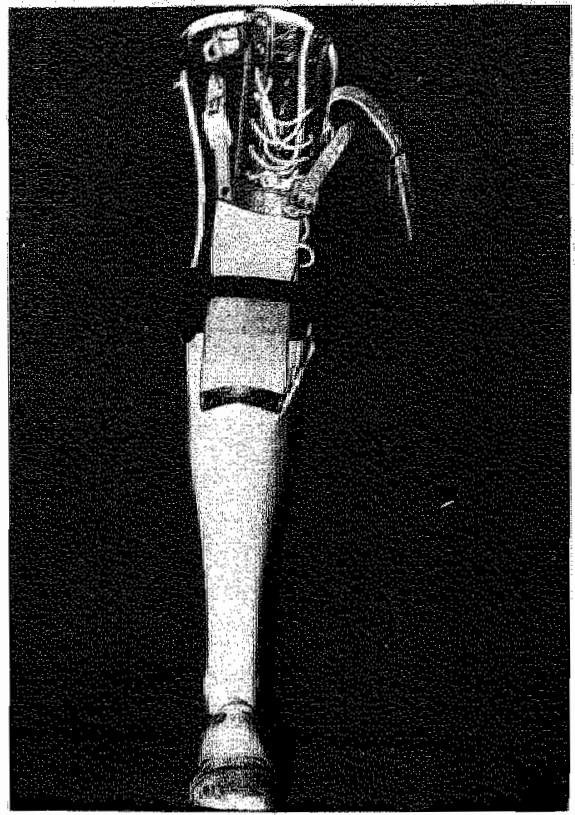

Fig. 53: Prothesebouwna
conventionele
knie-exarticulatie.

niet meer plaats vinden rond de femurcondylen. In onze overigens kleine ervaring, hebben wij dit theoretisch mogelijk nadeel nog niet ondervonden.

De tegenstanders van de modificatie van Mazet, o.a. Bar (1977) wijzen erop dat de eindbelasting door partieel trimmen van de femurcondylen geweld wordt aangedaan. Als tegenargument kan men wijzen op een uitspraak van Dederich (1970): ,Ich habe eine ganze Reihe von Gritti-Stümpfen aus dem Ersten Weltkrieg nachoperiert. Die Patienten waren meist 40 Jahre und länger mit ihren Stümpfen zufrieden gewesen, bis dann im höheren Lebensalter durch zusätzliche Gefäßschäden Beschwerden auftraten, die eine Nachoperation im Sinne einer Muskelplastiek erfordern. Ich finde daß man Stumpfformen die 40 Jahre und länger beschwerdenfrei ihren Dienst versahen, als wirklich gut bezeichnen muB".

Toch is nota bene het draagvlak van een goede Gritti-Stokes amputatie wezenlijk kleiner, vergeleken met het partieel trimmen van de femurcondylen volgens Mazet (1966).

Laatstgenoemdle auteur volgde een reeks patiënten, waarbij in 1966 bericht werd over 8 volwassenen en 6 kinderen. Nogmaals volgde een follow-up in 1977. Van de 8 volwassenen was intussen I persoon overleden aan een osteogeen sarcoom.. ,None of the surviving patients have had any trouble with the stump or with the prostheses that they have been using, and all have led active lives in the interval between the previous report and the presentone"'. (Mazet 1978.)

Van de 6 kinderen konden er 3 , overigens slechts ten dele, gevolgd worden. Van deze 3 stierf één kind aan een hersentumor; de beide andere waren bij de laatste controle resp. 13 en 21 jaar oud en ,, all were doing weill". De andere 3 kinderen, van wie én met een bilaterale knie-exarticulatie: ,, were doing well at the time of writing when they were twenty-one to twenty-four years 
old and were walking well with prostheses. They had no significant problems with the prostheses or with their stumps". (Mazet 1978.)

Sedert 1966 werd een andere groep, bestaande uit 19 kinderen en $27 \mathrm{vol}$ wassenen gevolgd na een hetzij gedeeltelijke hetzij volledige knie-exarticulatie volgens Mazet (1978).

De amputatieleeftijd van 16 kinderen lag tussen 1 week en 14 jaar. De 3 andere kinderen waren geboren met een congenitaal gemis van onderbeen en voet en een konische congenitale beenstomp en werden ook van knieexarticulatieprothesen voorzien.

De indicatie tot exarticulatie bij de 16 kinderen was:

9 t.g.v. een congenitaal defect

2 t.g. $v$. een osteogeen sarcoom

l t.g.v. een synoviaal sarcoom

l t.g.v. metastase van een Wilm"s tumor

3 t.g.v. een trauma

Ook Mazet meldt een verminderde lengtegroei van het femur na exarticulatie in het kniegewricht, alsmede een vermindering van de breedte der epiphysairschijf. Het grootste verschil in lengte bij de onderzochte groep kinderen bedroeg $6,4 \mathrm{~cm}$ vergeleken met het andere been. Gemiddeld was het verschil $4,57 \mathrm{~cm}$.

Van de 27 volwassenen was de indicatie tot knie-exarticulatie:

18 t.g.v. trauma, gecombineerd met infectie

2 t.g.v. arteriosclerosis

I t.g.v. Morbus Buerger

2 t.g.v. diabetes mellitus

2 t.g.v. osteosarcoom

2 t.g.v. infectie.

Van deze 27 volwassenen hadden 14 personen aanvankelijk een onderbeenamputatie ondergaan.

De re-amputatie (knie-exarticulatie) vond plaats 2 maanden tot 12 jaar later. Van deze 27 volwassenen waren 17 patiënten geopereerd volgens de modificatie van Mazet. Van deze 17 patiënten moesten 2 patiënten later wegens ontsteking van de amputatiestomp alsnog een bovenbeenamputatie ondergaan. 2 Anderen weigerden, na aanvankelijk geslaagde prothesevoorziening en looptraining, van hun prothese gebruik te maken. De 27 volwassenen hadden een gemiddelde leeftijd van 35,5 jaar ( $\min .19-\max _{\text {. }} 61$ jaar).

In dezelfde periode ondergingen een aantal andere volwassenen een bovenbeenamputatie. Hierbij was de gemiddelde leeftijd 47 jaar (min. 21 max. 73 jaar).

De tijd tussen operatie en prothesevoorziening bij de 27 personen bedroeg gemiddeld 1,7 maand. De tijd tussen amputatie en ontslag uit het ziekenhuis was 2,8 maanden.

Voor de groep met de bovenbeenamputatie waren deze tijden respectievelijk 5,3 en 11,3 maanden, terwijl niet alle personen ambulant werden.

Alhoewel het verschil in beide groepen mede bepaald werd door grotere 
vasculaire insufficièntie en combinatie met andere degeneratieve ziekten, is het verschil in revalidatieduur wel opmerkelijk.

Mazet (1978) maakt voor de genoemde reeks patiënten gebruik van 2 typen prothesen, waarmee het R.C.H. tot nu toe geen ervaring heeft. De reeds eerder vermelde problemen bij de prothesevoorziening na knie-exarticulatie hebben entoe geleid dat een groot aantal prothesetypen op de markt zijn gebracht om de bezwaren, ook op cosmetisch terrein, zo klein mogelijk te maken. Ook nu, nu zoveel geavanceerde prothesetypen competitief om voor rang roepen en de ,medical engineer" ook bij de prothesebouw zijn intrede heeft gedaan, blijft het R.C.H. steeds de , simpelste " oplossing zoeken voor elke geamputeerde met inachtneming van andere parameters. De reden hiervan is dat, hoe meer technische snufjes gebruikt worden bij prothesebouw, hoe groter de kans op averij. De tweede reden is dat ook bewust rekening gehouden wordt met de kostenfactor.

De orthopaedische werkplaats, welke deel uitmaakt van het R.T.H. werkt nauw samen met het amputatieteam van het R.C.H. De orthopaedische werkplaats maakt bij een knie-exarticulatie gebruik van een koker van gewalkt leer dan wel van giethars. Door het trimmen van de femurcondylen kan het zuigprincipe worden toegepast. Op de bodem van de koker rust een klein plastazote kussentje dat, samen met een der ventielsoorten een onderdruk levert, voldoende voor fixatie aan het lichaam. De verbinding met het prothese-onderbeen wordt verzorgd middels 2 eénassige, driedelige scharnieren, die na afwerking van de prothese nagenoeg onzichtbaar zijn en zo tegemoet komen aan de cosmetische wensen van de patiënt.

De SACH-voet (Solid Ankle Cushioned Heel) completeert het geheel. Overigens werd in 1977 deze voet meerdere malen in gewijzigde vorm gebruikt. Naast de standaard ingebouwde plantairflexie werd een elastische dorsaalflexie aangebracht middels een rubber plug. Door keuze naar consistentie van deze plug ontstaat een variabele mogelijkheid tot dorsalflexie. De continuiteit van het loopproces wordt zo bevorderd met een te aanvaarden verlies aan stabiliteit. Overigens is dit procedé, zij het op een andere manier uitgevoerd, eerder op de markt gebracht, echter wel duurder dan de zogenaamde Combi-voet van het R.T.H.

Deze door het R.C.H. gebruikte prothese-uitvoering bij een knie-exarticulatie werd vergeleken met de zogenaamde ,pneumatic supracondylar suspension for knee-disarticulation prostheses", beschreven door Bar (1977). Hierbij wordt. na conventionele amputatie in het kniegewricht. gebruik gemaakt van een gietharskoker met een inwendige flexibele en een uitwendige starre gietharskoker. 2 Opblaasbare rubberen zakjes bevinden zich tussen beide kokers ter plaatse van het supracondylaire gebied. De patiënt trekt de prothese aan, hetgeen gemakkelijk gaat, omdat de uitwendige gietharskoker konisch gevormd is. Daarna worden de rubberen zakjes door de patient opgeblazen middels een slangensysteem dat boven de protheserand afgesloten kan worden door middel van een ventiel, wanneer de door de patiënt gewenste druk ter fixatie van de prothese aan het lichaam bereikt is. De rubber ballon, afkomstig van een standaard bloeddrukmeter, wordt daarna verwijderd. (Fig. 54)

De voordelen van deze pneumatische ophanging zijn volgens Bar (1977): 

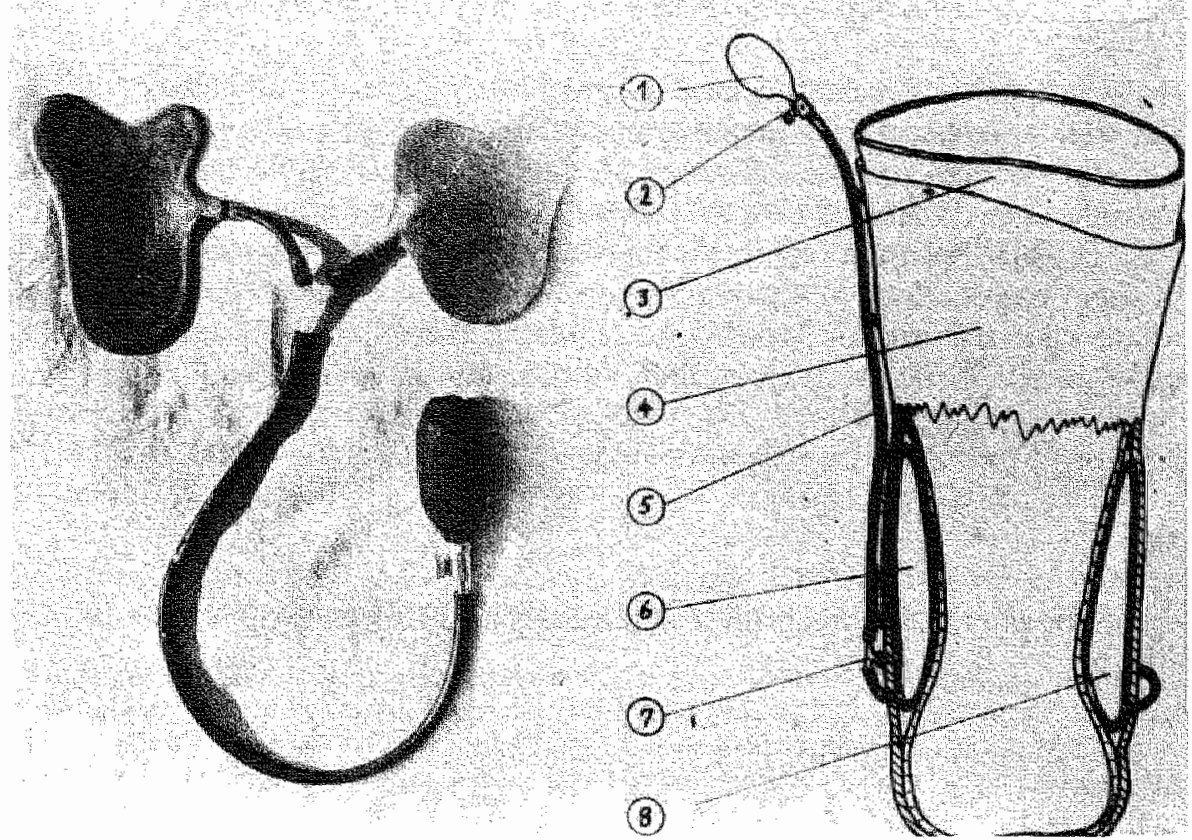

Fig. 54: Prothesekokerbouw bij: ,pneumatic supracondylar suspension for knee-disarticulation" volgens Bar.

a. Een goede ,,grip" van de koker op de stomp, waardoor het op en neer schuiven van de koker rond de stomp verminderd wordt. (reduced ,"piston" action).

b. Gemakkelijke en snelle montage.

c. Een mogelijkheid tot aanpassing van de druk aan variaties in het stompvolume, opgeroepen door klimatologische veranderingen, variaties in gewicht en optreden van oedeem.

d. Gelijke drukverdeling in de omgeving van de rubberen zakjes en daardoor eliminatie van een drukconcentratie op de weke delen.

e. De mogelijkheid om tijdens langdurig zitten de druk te laten zakken en het contact met de stomp aangenamer te maken, zonder dat te dien einde de gehele prothese uitgetrokken hoeft te worden.

Ad. a.

Een goede "grip" van de koker op de stomp is bij de door het R.T.H. toegepaste prothese eveneens aanwezig, hetgeen zal blijken uit de later volgende mededelingen.

Ad. b.

De veel eenvoudiger R.T.H. prothese zal in snelheid en gemak van montage zeker niet onderdoen voor de ,,pneumatic suspension prosthesis"; integendeel! 
Ad.

Bij een goede begeleiding van een prothesedrager mag een gewichtsvariatie, Welke een laakbare stompomvangtoename oproept niet voorkomen. Optredend oedeem, door welke oorzaak ook, dient de arts te bestrijden. De variatie in luchtdruk, welke de patient kan toepassen om de hinder, opgeroepen door het oedeem, te nivelleren laat de arts onwetend omtrent het bestaan van oedeem. Klimatologische veranderingen, met als gevolg meestal hinderlijke transpiratie wordt niet te niet gedaan door een pneumatische ophanging; de rubber zakjes zullen bij daarvoor gevoelige patiënten eerder een nadeel $z i j n$.

Ad. d.

De door het R.T.H. gebruikte prothese is juist bedoeld voor eindbelasting alleen.

Ad. e.

Dit is in tegenspraak met het door Bar (1977) gestelde: ,, The pressure in the bags can be adjusted by the amputee and once the desired pressure has been reached the valve can be locked and the bulb removed".

Het losdraaien van het ventiel, ook in minder huiselijke omgeving, kan bij de R.T.H. prothese-uitvoering geschieden ,,door de kleding heen". De patiënt van Bar zal zich, gezien zijn opmerking ,,and the bulb removed" toch moeten afzonderen, zo dit al mogelijk is bij het afwezig zijn van de benodigde luchtdruk ter fixatie van de prothese aan het lichaam.

3 Nadelen van de ,,pneumatic suspension prothesis" zijn bovendien:

a. het gebruik van meer materialen en arbeidsuren, waardoor de prothese duurder wordt.

b. De kans op plotseling defect raken van een onderdeel van het gehele pneumatische systeem. Deze kans is groter vergeleken met de R.T.H. prothese, aangezien het ophangsysteem uitgebreider is.

c. De verleiding om de druk groter te maken dan noodzakelijk is, een ervaringsfeit bij bejaarde mensen. De omstandigheid dat deze druk niet objectief te controleren is, maar alleen subjectief is te bepalen, kan onaangename gevolgen hebben. (Awater pers. mededeling.)

De door het R.T.H. gebezigde ventielen bij een zuigprothese kunnen afgesteld worden, zonder dat de prothesedrager hier enige invloed op kan uitoefenen.

Tenslotte een laatste opmerking van Bar (1977), die de waakzaamheid van de prosthetic surgeon niet mag doen verslappen: ,,The study was conducted at the Department of Bio-Medical Engeneering in the Technion-Israel Insti- 
tute of Technology and the Biomechanics unit of the Loewenstein Rehabilitation Hospital".

De techniek kan de medicus hier goede diensten bewijzen, maar de patiënt mag nooit ondergeschikt gemaakt worden aan technische vindingen, waardoor de mens, de patiënt, in dienst staat van de techniek. Overigens werd deze ,,pneumatic suspension prosthesis" slechts éénmaal bij een 38 -jarige patiënt toegepast, waarna publicatie volgde. Hier staat tegenover de rapportage van Mazet (1978) omtrent in totaal 60 patiënten, welke follow-up zich over een groter aantal jaren uitstrekt.

Het R.C.H. heeft slechts een beperkte ervaring met patiënten, waarbij de knie-exarticulatie ten dele dan wel geheel volgens Mazet (1966) werd verricht. De betreffende casuistiek is wel illustratief voor de problematiek rond dit amputatieniveau.

A. Een Congolees meisje, geboren in 1954, was medio 1973 betrokken bij een verkeersongeval, als gevolg waarwan zij een tibiaplateaufractum links opliep alsmede een fractura cruris links.

Aanvankelijk werd zij conservatief behandeld. Er ontstonden echter circulatiestoomissen. waardoor een amputatie van het linker onderbeen in september 1973 noodzakelijk werd. Aange zien in Brazzaville geen prothesevoorziening en fooptraining kon plaats vinden, werd via de organisatie, "Terres des Hommes" aan het R.C.H. gevraagd de revalidatie van dit meisje over te willen nemen.

De eerste moeilijkheid, waarmee wij geconfronteerd werden, was het feit dat de tibiaplateaufractuur geen adequate prothesevoorziening zou toelaten. (Fig. 55)

De röntgenfoto liet overduidelijk zien dat op zeer korte termijn arthrot ische veranderingen zouden ontstaan met als gevolg een pijnlijke en niet bruikbare kniefunctie. Met de patiènte en een chirurg werd overleg gepleegd om ower te gaan tot een knie-exarticulatie volgens Mazet (1966). (Fig. 56) Een voorstel tot reamputatie wordt niet gemakkelijk geaccepteerd door een patiënt. maar in dit geval was het onvermijdelijk en konden wij voldoende argumenten aandragen om ook haar van de noodzaak ervan te overtuigen. Na de operatie zou dan een nog groter probleem opgelost moeten worden; immers wanneer in Brazzaville en volgens onze inlichtingen nergens in Congo een orthopaedische instrumentmakerij gevestigd was, dan moest woor dit meisje een zeer eenvoudige prothese gemakt worden, waar nagenoeg niets aan stuk zou kunnen gaan. In elk geval zouden geen mankementen mogen optreden, die alleen maar hersteld zouden kunnen worden door een ervaren instrumentmaker in een goed geoutilleerde orthopaedische instrumentmakerij.

Tenslotte bestond van de kant van de jonge vrouw de begrijpelijke wens naat een cosmetisch frataie prothese.

Bij een conventionele knie-exarticulatie is de dan te maken prothese tan het stompuiteinde knotsvormig door de atanwezigheid van de femurcondylen. Aantrekken gelukt alleen met een geopende koker dan de voorzijde, terwijl daarna de veterband voor de nodige fixatie zorg moet dragen. Wanneer het looptempo van de patient nog redelijk is, moet aan de voorzijde een elastische band a tangebracht worden on de zwaaifase bij het naar voren brengen wan het prothese-onderbeen te verkorten.

Bij cen onderbeengeamputeerde, die een conventionele prothese met lederen dijbeenschacht draagt, treedt wrij snel atrofie op van de bovenbeenmusculatuar. Immers, de dijbeenschach neemt ten dete de taak wan de bovenbeenmusculattur over. Dat door deze atrofie de circulatie niet bevorderd wordt is duidelijk. (Nachbaur 1976.)

Een zelfde gebeuren zien wij bij een conventionele knie-exarticulatie, voorzien wan de eerder beschreven open kaker, gefit rond de femurcondylen en gesloten door middel van veterband. Deze atrofie met kans op circulatievermindering, leidt bij de bejaarde patiën dan op de duur tol witbreiding van de prothese, aangezien de atrofische musculatuur de prothese nilet meer nata behoren kan bedienen. Uitbreiding wan de probese houdt dan in een tuberzit alsmede een bekkenbandage. Al met al is deze conventionele prothese niet direct het summum van elegance.

Anders is dit bij de door het R.T.H. gemaakte zuigprothese, nat trimmen van de condylen 


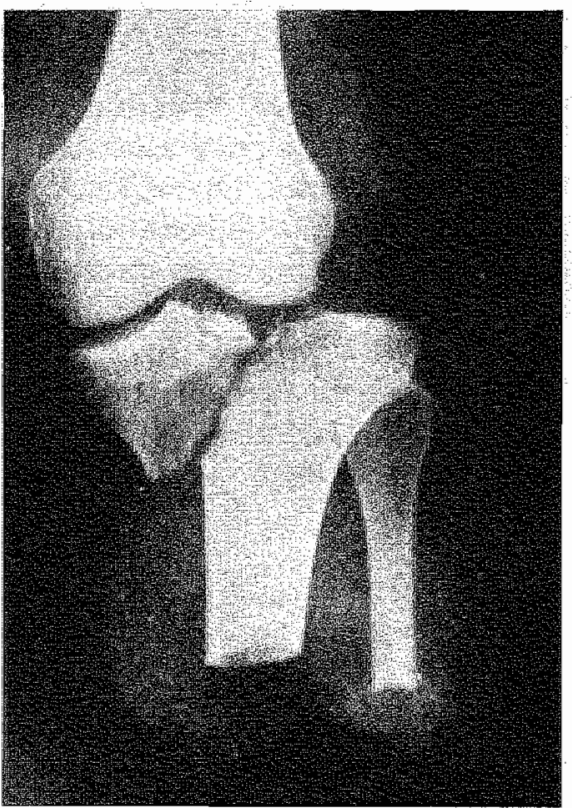

Fig. 55: Niet correcte onderbeenamputatie en tibia-plateaufractuur.

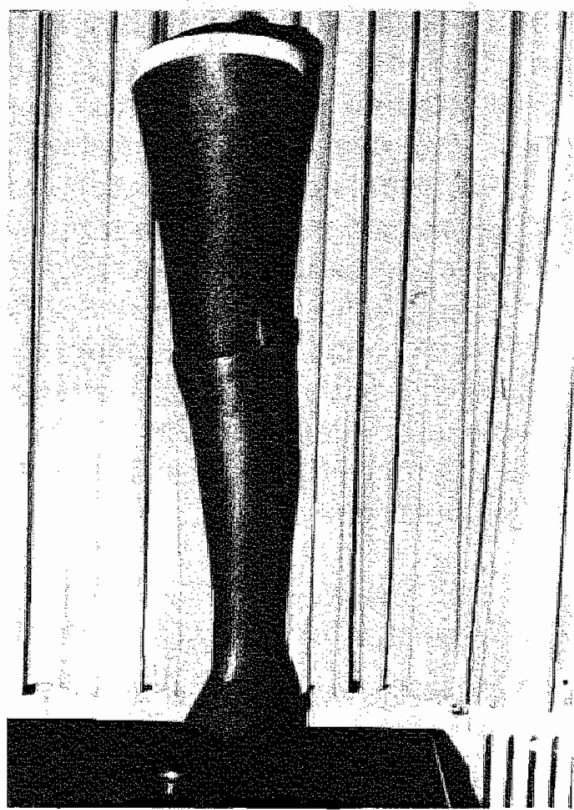

Fig. 57: Zuigprothese na

knie-exarticulatie volgens Mazet.

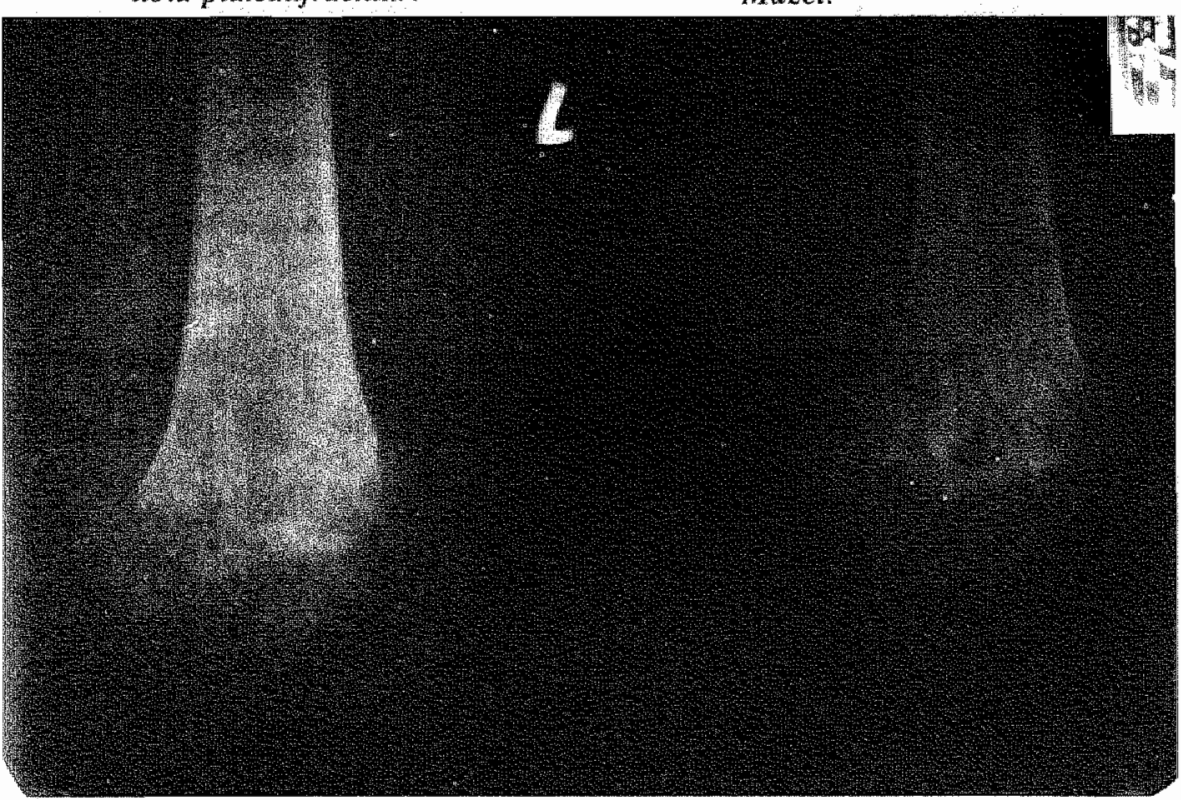

Fig. 56: Knie-exarticulatie volgens Mazet.

volgens Maret. De zuigprothese dwingt de patiënt bij gaan en staan meer zijn bovenbeenmusculatuur te gebruiken, watardoor de optredende atrofie minimaal is en het uiteindelijke, stakerige aspect van het femur, bedekt door geatrofieerde weke delen, achterwege bliff. Dit komt de .cosmetiek" van de stomp. door vrouwen extra gewaardeerd, ten goede. Gevolg is bovendien dat, ook op langere termijn. tuberzit en bekkengordel achterwege kunnen blijven. 
Bij de betreffende patiënte werd de zuigprothese, zoals, eerder beschreven, uitgevoen in giethars. Het geheel werd overtrokken met leer, hetgeen onze jongedame, passend bij hatar huidskleur zelf kon uitzoeken. Het resultaat was een cosmetisch fraai ogende prothese, watran bijna niets stuk kon gaan, behalwe slijtage van leer, heigeen in Congo wel hersteld zal kunnent worden. (Fig. 57)

B. In 1974 werd een man opgenomen, geboren in 1914. Sinds 1969 leed hij atan claudicatio intermittens van beide benen, waarvoor hij in dat jaar diverse vaatoperaties onderging. $\mathrm{Na}$ aanvankelijke verbetering van de klachten namen deze in 1973 beiderzijds weer toe. In februan 1974 vond opnieuw aan beide benen een vasoreconstructieve ingreep plaats. Het rechter been herstelde; links verliep de woorwoetnecrose progressief. In september 1974 volgde een onderbeenamputatie links met myodese en myoplastiek, waarna opname in het R.C.H.

De anamnese vermeldde een passagère hemiparese links in 1965. In 1969 was hij wegens cardiale klachten diverse malen op een interne afdeling opgenomen geweest. De man was werkzaam geweest als sleepbootkaptein, tot hij in 1969 een uitkering kreeg krachtens W. A.O.

Het linker onderbeen was geamputeerd $18 \mathrm{~cm}$ onder de mediale gewrichtsspleet van de knie. Het litteken was goed genezen en er bestond een goede weke delen bedekking. Het kniegew richt vertoonde geen contractuur.

Het distale deel van het rechter onderbeen liet een glimmende, gladde hutid zien. Kalknagels en een cyanotische se teen completeerden het beeld. De arteria tibialis posterior was dubietss palpabel.

Het E.C.G. toonde verscheidene supraventriculaire extrasystolen, alsmedle een oud infarct van de achter-onderwand. Bij cardiotelemetrisch onderzoek, waarbij de patient hinkte in de loopbrug, bleek de coronaire circulatie mee te wallen.

Bij de looptraining met een conventionele onderbeenprothese reageerde de amputatiestomp minder gunstig. Dit betekende dat het trainingsprogramma regelmatig onderbroken moesi worden om de optredende defecten te laten genezen. De indruk bestond dat de pasworm van de prothese niet veel bijdroeg tot het ontstaan van deze defecten. Op een gege wen moment kwam de man te vallen, waarbij een diffuus haematoom in de stomp ont stond. Ten gevolge hiervan. samen met de insufficiënte circulatie in de stomp, ontstond aan de mediale zijde van het litteken een flinke dehiscentie. Er was een slechte genezingstendens en langzaam uitbreiding van het defect. Besloten werd tot re-amputatie. Op ons verzoek werd in april 1975 een knie-exarticulatie volgens Mazell (1966) verricht. (Fig. 58 en 59)
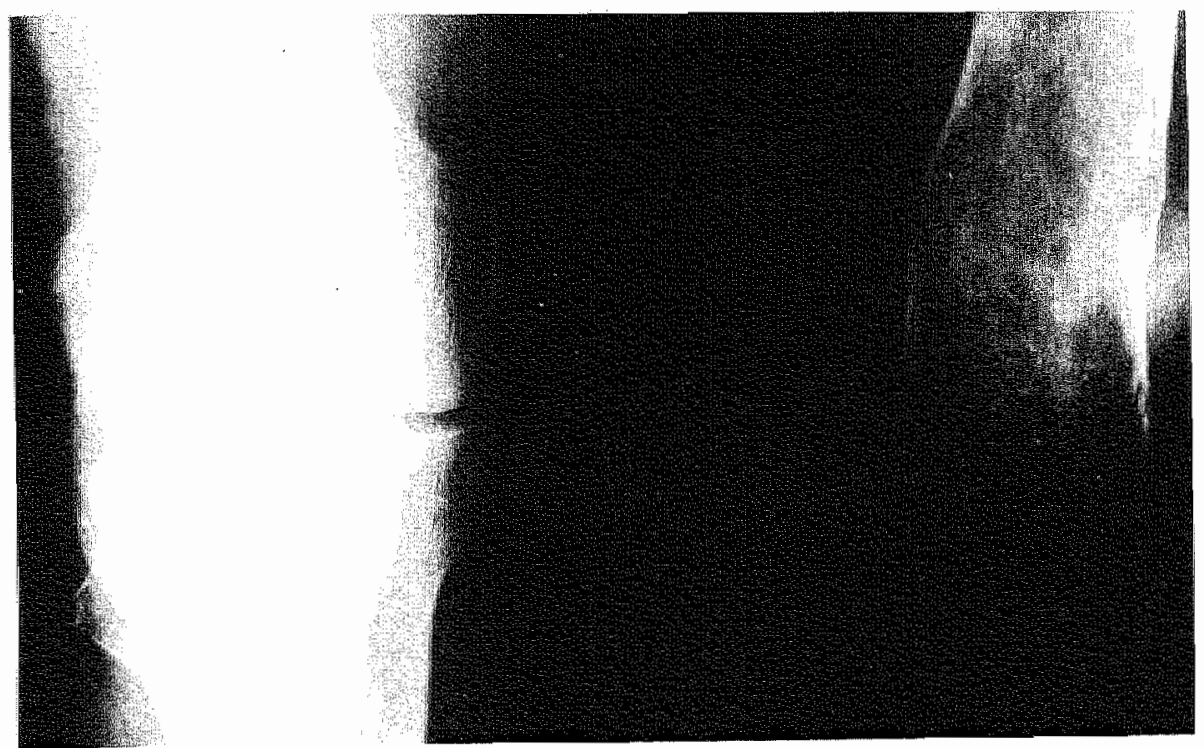

Fig. 58: Knie-exarticulatie volgens Mazet. 


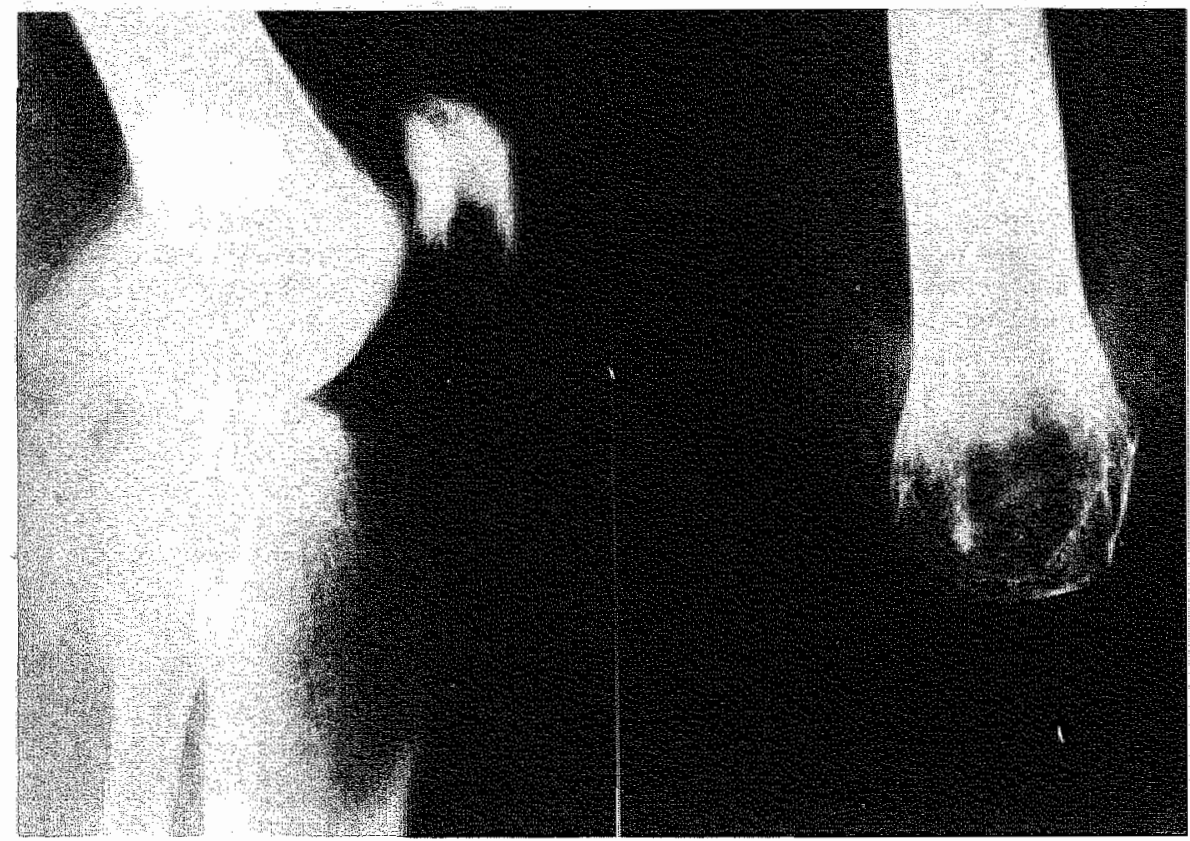

Fig. 59: Knie-exarticulatie volgens Mazet.

Beide Rö-foto's laten duidelijk de omvang-afname zien van het distale femuruiteinde, waardoor toepassen van een zuigkoker mogelijk wordt.

Na heropname in het R.C.H. waren de cardiale bevindingen gelijk geblewen. Na woorzien te zijn van een giethars zuigprothese verliep de verdere revallidatie vlot. Bijontslag liep de man met I stok.

Na ontslag zagen wij hem regelmatig terug op het prothesespreekuur. Van lieverlede hoefde hij de stok niet meer te gebruiken. Aangezien hij als oud-sleepbootkapitein toch een hang naar het wattel had, ging hij vaker mee op reis met zijn zoon. sleepbootkapitein op de binnenwateren. Het lopen in hel gangboord gaf, 20 vertelde hij, geen problemen. Dit zou wel het geval zijn geweest na. bovenbeenamputatie, gezien thet daarbij meestal optredende symptoom van Trendelenburg. hetgeen bejaude mensen noopt tot het gebruik maken van minstens 1 stok. Bij de laatste controlle in april 1978 deelde hij mee dat hij voor een carawanvakantie 3 weken naar Frankrijk vertrok. Op de lerugreis hiervan overleed hij an een hartinfarct. 3 Jaar lang had hij een leven geleid zoals hij zich dat nog kon wensen en dat ook gezien vanuit het mens-machine-milieusysleem als optimstal in de gegeven omstandigheden kan worden gekenschetst.

C. Een vrouw geboren in 1918 , lijdt sinds 1956 aan een ernstige rheumatoide arthritis. Datarenboven kreeg zij in 1969 pijnklachten in het rechter onderbeen, welke op vatsculaire insulficiëntie bleken te berusten.

In 1970 wend beiderzijds een lumbale sympathectomie verricht. Hiena had zij gedurende 2 jaar minder klachten. Intussen volgde regelmatig controle en behandeling door de theumatoloog.

Er ontstonden rugklachten, welke bleken te berusten op compressiefracturen van Thoracale $X$ XI en XII. alsmede van enkele lumbale wervels. De oorzak thiervan moest in de medicamen. teuze therapie met corticosteroiden gezoch worden.

In juli $\| 973$ ontstond een geringe necrose wan de 4e teen rechts, gevolgd door een vaatoperatie wetke in september van dat jaar platats vond. Jammer genoeg breidde het necrotische proces zich langzazm wit. Op advies van de revalidatie-arts in het ziekenhuis werd een kniemexarticulatie rechts verricht. Whatbij ook de patella werd geextirpeerd. (Fig. 60 en 61 ) De wondgenezing was vertragd, zoals te verwachten whts. 


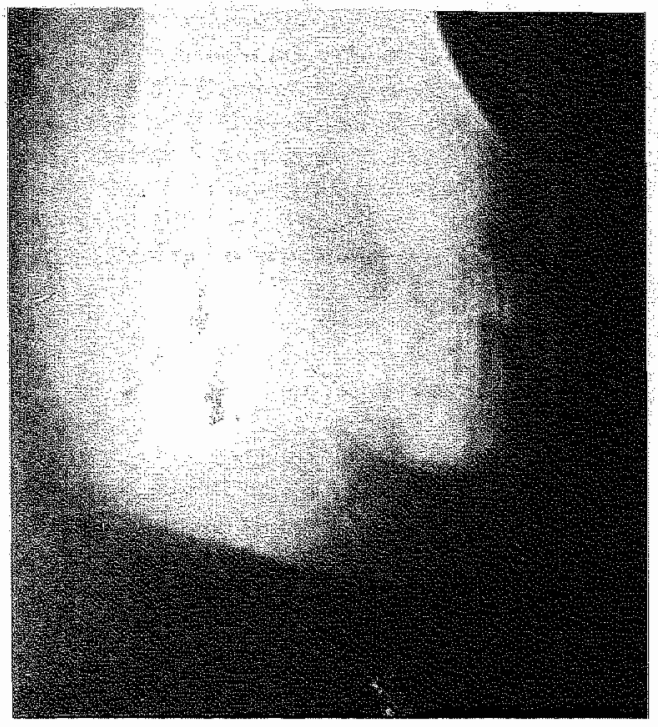

Fig. 60: Knie-exarticulatie rechts volgens Mazet.

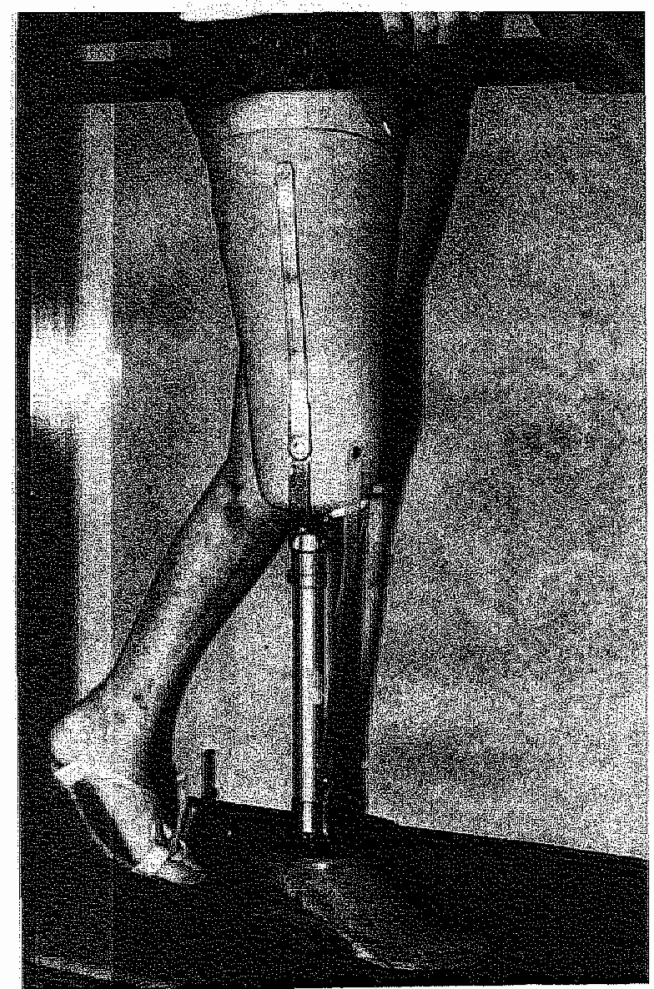

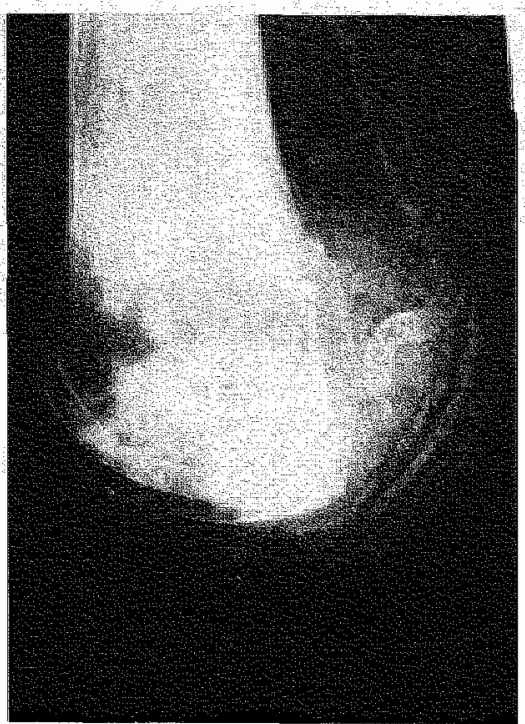

Fug. 61: Knie-exarticulatie rechts volgens Mazet.

Fig. 62: Looptraining met giethars-zuigprothese in het loopbad ter ontlasting van de bovenste extremiteiten. 
Zij werd opgenomen in het R.C.H. woor prothesevooniening en verdere revalidatie.

Def functiebeperkingen op basis wan de the umatorde arthritis waren woomamelijk aanwezig in de bovenste extremiteiten. Bij cardiotelemetrisch onderzoek concludeerde de functie-arts dat er spriake was van een sterk verhoogd nisico bij eventuele looptraining na prothesevoorziening. Gelukkig was de hartfunctie medicamenteus goed te beinvloeden en bij cardiotelemetrisch onderzoek, 1t:2 maand later. kon zowel subjectief als objectief van een frati resultat gesproken worden.

De vrouw werd in het R.C.H. vanaf het begin begeleid door de rheumatologe van het R.C.H. Har conclusie, na onderzoek bij opname, luidde:

a. Rheumatoide arthritis, woornamelijk actief in handen, polsen en rechter elleboog.

b. Myalgièn wan de schoudergordel zonder duideljike arthritis.

c. Osteoporose en spontaan fracturen.

De rheumatologe adviseerde de vrouw te gaan mobiliseren zonder veel belasting wan de bovenste extremiteiten. Van meet af aan worden echter bij een looptraining na prothesevoorziening de beide armen ingeschakeld.

Begonnen werd met oefeningen in het wlinderbad en fango voor de schoudermusculatuur. Hierdoor verbeterde de bestaande functiebeperking in de diverse gewrichten. In verband met het advies van de theumatologe vond de daarop volgende looptraining met de prothese plaats in het loopbad met dallend waterniveau. Hierdoor kon de patiënte zich een looptechniek eigen maken zonder de bovenste extremiteiten te belasten. (Fig. 62)

Bij dalend waternivealu werd zeer gedoseerd de belasting van de armen opgevoerd en $2 \mathrm{l} / 2$ maand na opname liep zij in de loopbrug. 1//2 Maand later kon zij goed lopen met tricepskrukken. 2 Maanden later liep zij zonder gebruik te maken van een handsteun. De vrouw was erg enthousiast en moest regelmatig afgerend worden, aangezien het theumatische proces duidelijk de indicatie hiervoor gaf.

Enkele maanden na ontslag ontstond een lichte necrose van de linker grote teen, welke progressief was. Een amputatie werd noodzakelijk en op ons verzoek werd een poging gedaan de linker knie te behouden door een onderbeenamputatie te verrichten. Dit gelukte ondanks de uitgesproken watwand veranderingen. (Fig. 63 en 64)

Weer werd zij in het R.C.H. opgenomen. Dank zij haar wiskractht, zo men wil motivatie, kwam zij. Ondarlks deze bilaterale amputatie op grond van een uitgebreid vaatlijden naast een ernstig rheumatisch proces tot lopen, waarbij zij gebruik maakte van 2 tricepskrukken. Van een electrische rolstoel wordt ook binnenshuis slechts matig gebruik gemaakt.

Alleen afgaande op de bestaande watwandveranderingen, zichtbaar bij arteriografisch onderzoek, zou voorheen beiderzijds een bovenbeenamputatie zijn verricht, omdat op grond van het ernstige rheumatische proces de kans op looptraining en revalidatie nihil zou zijn geacht. . Few if any areas of major surgery present the challenge currently offered by amputations".

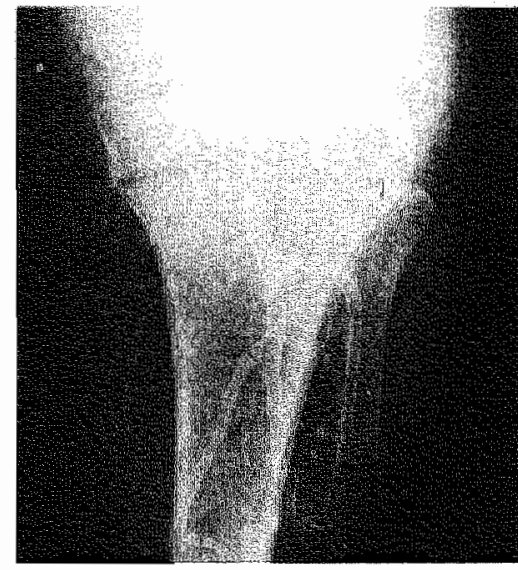

Fig. 63: Onderbenamputatie links.

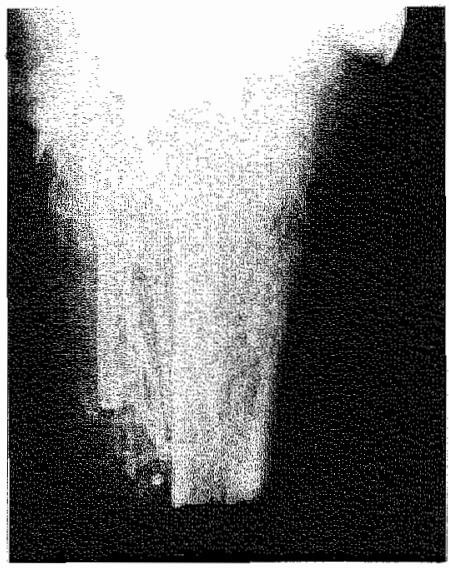

Fig. 64. Onderbeenamputatie links. 
D. De laatste ziektegeschiedenis handelt over een jongeman, geboren in 1953 . In Januari 1972 was hij betrokken bij een auto-ongeval. Ondermeer thep hij hierbij een gecompliceende onderbeenfractur links op. Na aanvankelijke conservatieve behandeling moest I maand later tot een hoge onderbeenamputatie worden overgegatn.

Na genezing van de andere letsels werd hij in april 1972 lopend met krukken ontslagen.

Bij controle in juni 1972 door de revalidatie-arts was de slechts $4 \mathrm{~cm}$ lange onderbeenstomp matig drukpijnlijk. Gezien de fraaie kniefunctie werd toch besloten tot een conventionele prothesevoorziening.

De jongeman leerde redelijk lopen, zij het met behulp van 2 krukken. In september 1972 ontstonden huiddefecten en was het lopen uiterst pijnlijk. Wijzigingen wan de prothesekoker gaven geen verlichting van de klachten. De eerst behandelende chirurg stelde uiteindelijk re-simputatie op bovenbeenniveau voor. Dit werd echter halsstarrig afgewezen door de geleidelijk wat depressief geworden patient. Zijn beroep kon hij niel meer uitoefenen en uiteindelijk werd hij te werk gesteld bij de ZOL-bedrijven. (ZOL: W.S. W. Werkplaats Zuid-Oost-Limburg.) Regelmatig moest hij ook hier zijn werk neerleggen vanwege pijnlijke stompklachten.

In 1975 werd hij de eerste maal gezien op het prothesespreekuur. Nogmaals werden enkele prothesekokerwijzigingen geprobeerd, die geen verbetering oplevenden. Tenstotte werd met de jongeman gesproken over een re-amputatie, hetgeen dan een knie-exarticulatie zou betekenen. Uiteindelijk kon de patiënt hiermede accoord gaan, warma in april 1978 de knie-exarticulatie werd verricht.

Tijdens de operatie werd een uitgebreide verbindweefseling vastgesteld. Daannast waren er een groot aantal draadgranulomen, een groot neuroom dat in een afgekapseld abces bleek to liggen en tenslotte een grote bursa onder de pes anserinus. Nadat de condylen zijdelings bijgetrimd waren, werden de dorsale en ventrale structuren aan de kruisbanden gehecht. Er werd afgezien van patellectomie.

De bevindingen van de patholoog-anatoom waren conform het operatieverslag. Het postoperatieve beloop was ongestoord.

Prothesevoorziening volgde middels een giethars zuigprothese. Binnen zeer korte tijd kwam de jongeman tot een fraai looppatroon, zonder hulpmiddel, dat voorheen altijd noodzakelijk was.

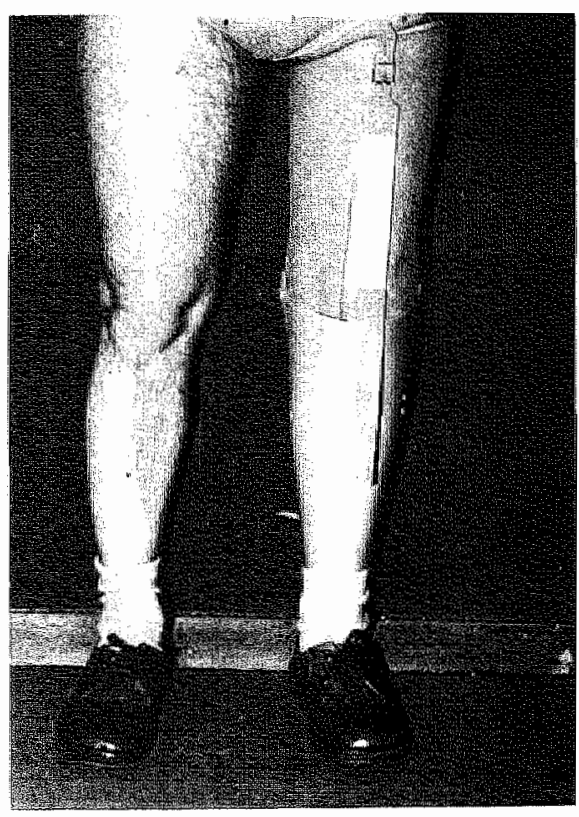

Fig. 65: R.T.H.-knieexarticulatieprothese. (vooraanzicht)

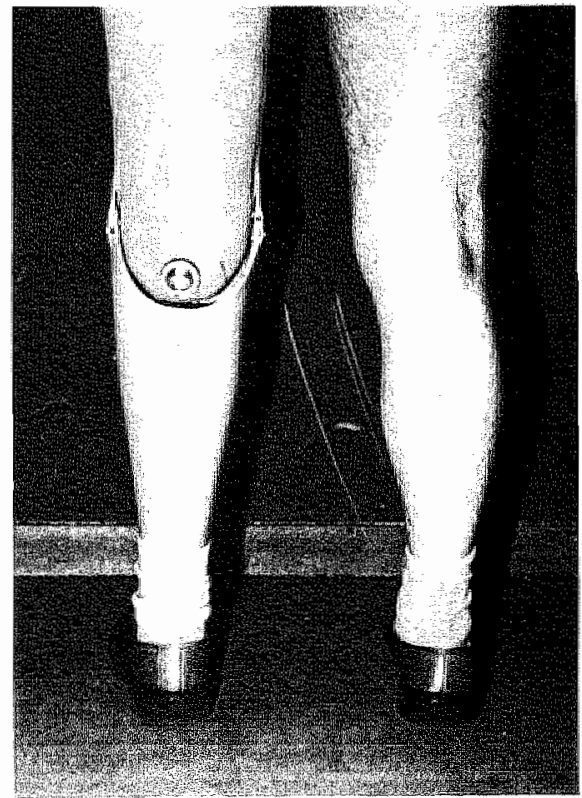

Fig. 66: R, T.H.-knieexarticulatieprothese. (achteraanzicht) 


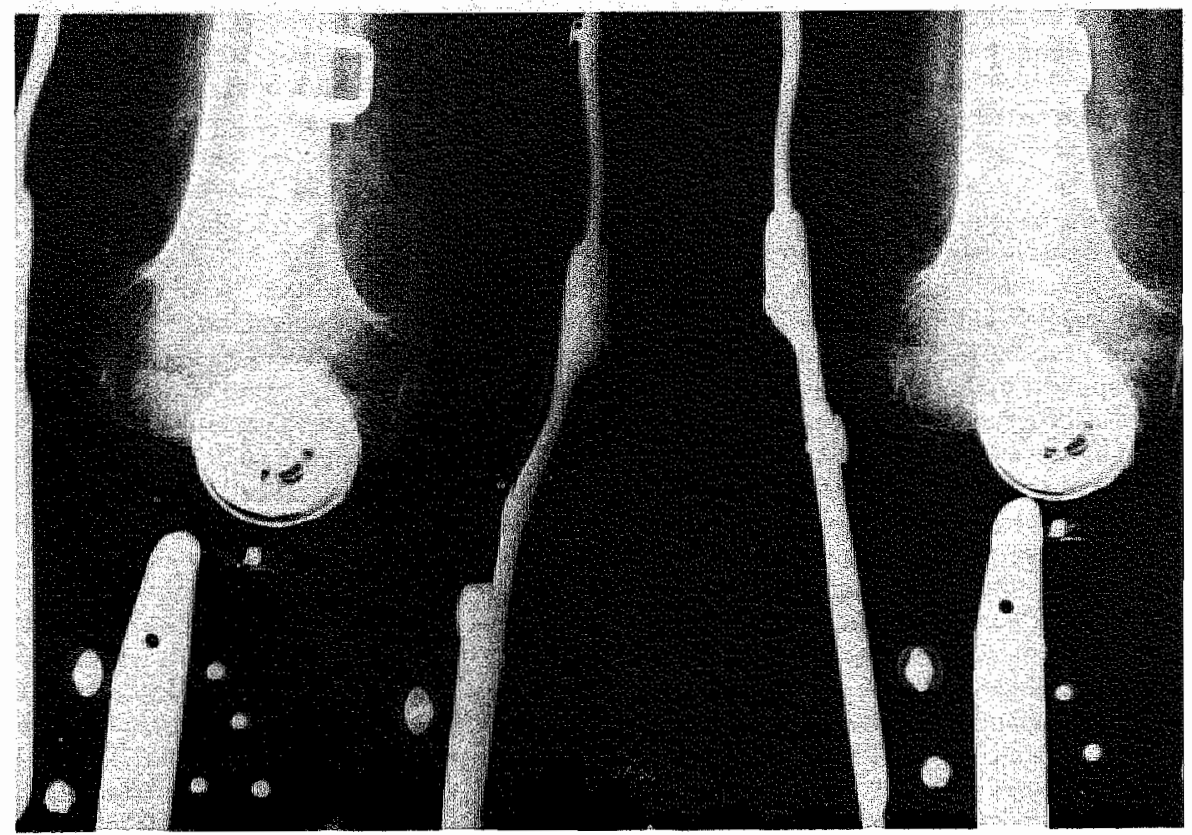

Fig. 67: Rö-foto van onbelaste (links) en belaste (rechts) prothese.

Desgevraagd gaf hij aan dat niet alleen de pijn volledig verdwenen was, maar dat hij ook beter kon lopen dan hij werwacht had. De $4 \mathrm{~cm}$ lange stomp was om meerdere redenen volslagen nutteloos gebleken, (Fig. 65 en 66)

De jongeman is een kandidaat voor het Centrum Beroepsopleidingen .,Hoensbroeck“" hetgeen als de affonding van een geslaagd revalidatieproces kin worden aangemerkt.

Epicrise betreffende de voor deze jongeman vervaardigde prothese. vergeleken met de , pneumatic suspension prosthesis" van Bar (1977):

Bar onderzocht de verplaatsing van de amputatiestomp t.o.v. de koker tijdens lopen, dat wil zeggen tijdens gaan en staan. Anders gezegd, de verplaatsing van de amputaties tomp in de koker. gemeten in onbelaste en belaste toestand, hetgeen röntgenologisch werd vastgelegd. Bar vindt dan bij de conwentionele knie-exarticulatieprothese een verplaatsing van $42 \mathrm{~mm}$. De .,pneumatic suspension" deed deze röntgenologisch gemeten verplaatsing datem tot $23 \mathrm{~mm}$.

Conform onze kritick op de ,pneumatic suspension" hebben wij ook dit gemeten bij de R.T.H.-prothese voor knie-exarticulatie na amputatie volgens Mazet (1966). Rekening houdend met een vergrolingsfactor van $11,5 \%$, welke ontstond door het röntgenologisch vastleggen van deze verplatsing, vonden wij bij deze patiënt een minimale verplaatsing van $2,5 \mathrm{~mm}$. (Fig. 67)

De knie-exarticulatie zal zijn nut in Nederland nog moeten bewijzen. Moge dit hoofdstuk ertoe bijdragen. 


\section{De toekomst, drogbeeld of realiteit?}

"It is now clear that the rehabilitation of the amputee does not depend solely on the operating theatre and the prosthetist's shop, but that a team approach is necessary if the amputee is to be returned to his home and work, integrated with his prosthesis and the community" (G. Murdoch, 1977).

Uit een door Bakker (1973) gepubliceerd onderzoek kan men afleiden dat in Nederland in 1969 het aantal op grond van vasculaire insufficiëntie verrichte amputaties 743 bedroeg. Dit is $79.4 \%$ van het totaal. Van deze 935 patiënten ondergingen 600 een bovenbeenamputatie. Slechts $55 \%$ van de 600 bovenbeengeamputeerden werd van een prothese voorzien. De overige $45 \%$ ofwel 270 patiënten bleven hiervan verstoken. Het merendeel van de op grond van een vaatlijden geamputeerden was 70 jaar en ouder.

Bakker vermeldt niet wat het lot was van deze 270 personen. Is het gewaagd te veronderstellen dat deze geamputeerden, gezien eigen ervaring in de zestiger jaren, voor het merendeel hun laatste dagen sleten in een verpleeghuis, veelal zonder hun eventuele partner die nog geen verpleging behoefde en waarvoor dús geen plaats was in het verpleeghuis? Zelfs in 1979 is het nog steeds geen voor de hand liggende zaak een geamputeerde, die, om welke reden dan ook, geen functionele prothesedrager kan worden en gedoemd is zijn verdere leven zittend in een rolstoel door te brengen, te huisvesten in een bejaardenhuis. Niet onwil, maar gebrek aan plaatsingsmogelijkheden en tekort aan (deskundig) personeel is de reden.

Men zou veronderstellenderwijs kunnen tegenwerpen dat in Nederland sinds 1969 meer op onderbeenniveau wordt geamputeerd, waardoor revalidatie en huisvesting een gemakkelijker zaak zouden zijn geworden. De cijfers verstrekt door de S.M.R. (Stichting Medische Registratie) ontnemen elke grond aan deze veronderstelling (tabel 34). In 1969 werden in Nederland 600 bovenbeenamputaties verricht tegenover 335 onderbeenamputaties. Bakker (1973). In 1977 waren deze cijfers respectievelijk 1086 en 796 (tabel 34 en tabel 37). Dit betekent dat in $196964.1 \%$ van de geamputeerden op bovenbeenniveau hun mutilatie ondergingen; in 1977 was dit $57.7 \%$. Deze daling van amputaties op bovenbeenniveau moge tot optimisme stemmen, echter een verdere daling heeft sinds 1971 niet meer plaatsgevonden (tabel 34). De daling van $64 \%$ naar $57 \%$ hangt mogelijk samen met een hernieuwde belangstelling voor te amputeren patiënten in de tweede helft van de zestiger jaren. Deze hernieuwde belangstelling is te zien als een gevolg van uitgebreide publicaties met betrekking tot myodese, myoplastiek en immediate fitting. 
Uitermate belangrijk en zorgwekkend is wel dat, bijeen sinds 1971 nagenoeg gelijkblijwend percentage amputaties op bovenbeenniveau, zich andere ontwikkelingen hebben voorgedaan, welke samenhangen met een veranderende bevolkingsopbouw in Nederland.

Dit is af te leiden uit de door de S.M.R. verstrekte gegevens omtrent ingrepen, betrekking hebbend op amputaties van de onderste extremiteit in Nederland en Limburg (tabel 34).

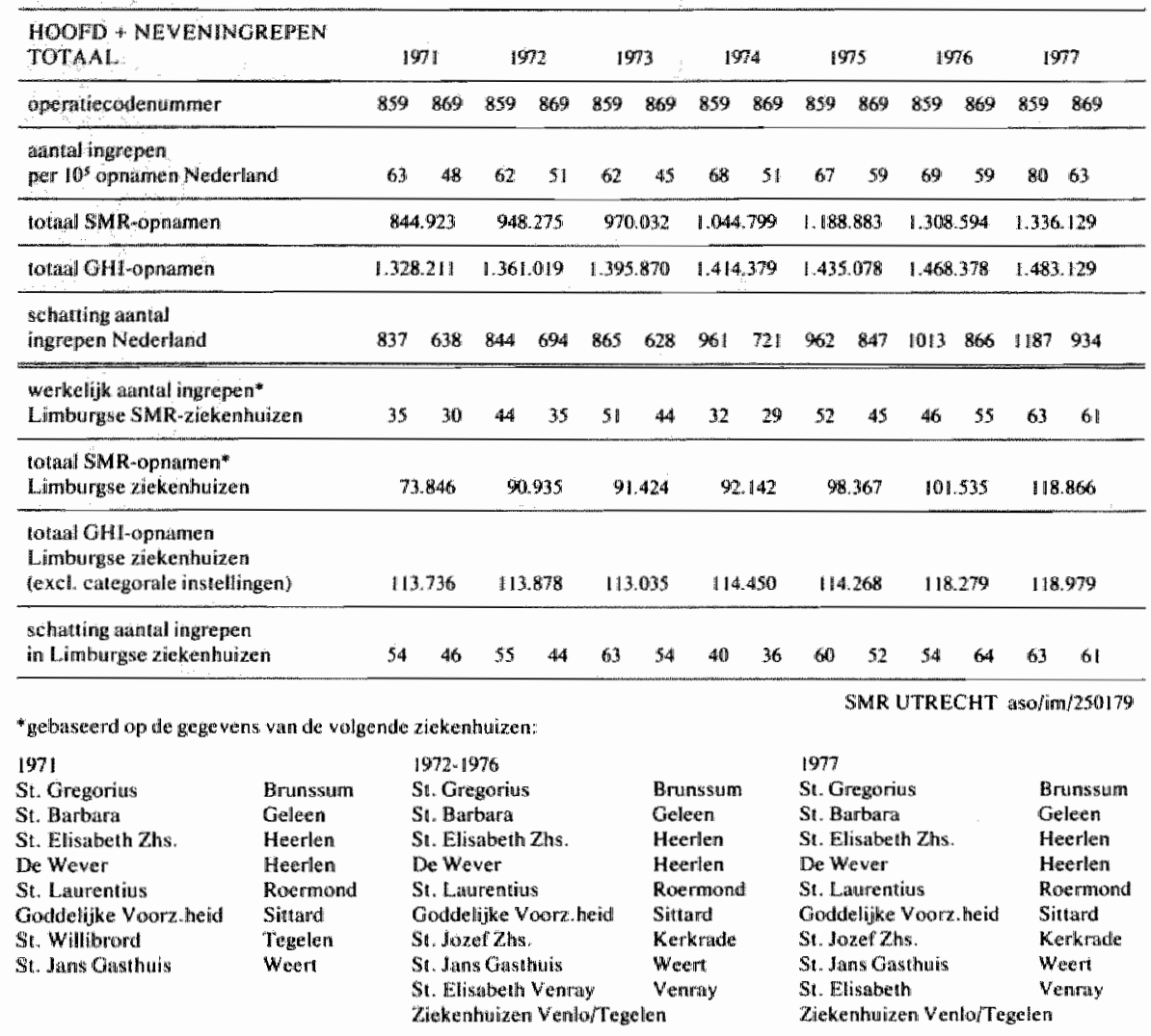

Tabel 34: Hoofd-en neveningrepen, horend tot de codegroepen 859 en 869 van de classificaties wan operaties, zoals geregistreerd in alle bij de S.M.R. aangesloten ziekenhwizen en in die, welke gelegen zijn in de provincie Limburg, betrekking hebbend op de jaren 1971-1977.

Tabel 34 geeft aan hoe met behulp van enerzijds het aantal ziekenhuisopnamen, zoals geregistreerd door de S.M.R. en anderzijds het totaal aantal volgens opgave van de Geneeskundige Hoofdinspectie (G.H.I.), schattingen gemaakt werden voor Nederland respectievelijk Limburg van het aantal ingrepen. Terwille van de duidelijkheid zij vermeld dat het totaal aantal S.M.R.opnamen werd berekend voor algemene en/of academische ziekenhuizen; categorale instellingen werden buiten beschouwing gelaten. De cijfers van de Geneeskundige Hoofdinspectie werden door de S.M.R. op analoge wijze aangepast.

Voor Nederland heeft een omrekening plaats gehad "per $10^{5}$ opnamen" zoals uit tabel 35 blijkt. 
De tussen haakjes genoemde afgeronde getallen stemmen overeen met die van tabel 34 onder rubriek "aantal ingrepen per $10^{5}$ opnamen Nederland".

Uitgaande van bovengenoemde aantallen per $10^{5}$ opnamen en het totaal aantal G.H.I.*-opnamen is het geschat aantal ingrepen in geheel Nederland te berekenen, welke vallen onder operatiecode no. 859 en no. 869 respectievelijk

\begin{tabular}{lccc}
\hline jaar & $\begin{array}{c}(1) \\
\text { SMR-aantal } \\
\text { operatiecode 859 }\end{array}$ & $\begin{array}{c}(2) \\
\text { total aantal } \\
\text { SMR }\end{array}$ & $\begin{array}{c}(3) \\
\text { SMR-aantal } \\
\text { code 859 per 105 opnamen }\end{array}$ \\
\hline 1971 & 530 & 844.923 & $62.7(=63)$ \\
1972 & 587 & 948.275 & $61,9(=62)$ \\
1973 & 602 & 970.032 & $62,1(=62)$ \\
1974 & 715 & 1.044 .799 & $68.4(=68)$ \\
1975 & 802 & 1.188 .883 & $47.4(=67)$ \\
1976 & 905 & 1.308 .594 & $69,1(=69)$ \\
1977 & 1073 & 1.336 .129 & $80,3(=80)$ \\
\hline
\end{tabular}

Tabel 35: Berekening S.M.R. aantal code 859 per 10s opnamen.

"amputatie en exarticulatie van het bovenbeen" en "amputatie en exarticulatie en opnieuw aanzetten van knie of onderbeen". De 3-cijferige codenummers hebben dus betrekking op meer ingrepen dan amputaties alleen (tabel 36 ).

\section{AMPUTATIE EN EXARTICULATIE VAN HET BOVENBEEN 859.0 AMPUTATIE VAN HET BOVENBEEN 859.1 EXARTICULATIE VAN HET HEUPGEWRICHT 859.2 HEMIPELVECTOMIE \\ 859.3 VERBETEREN VAN EEN AMPUTATIESTOMP VAN HET BOVENBEEN}

869 AMPUTATIE, EXARTICULATIE EN OPNIEUW AANZETTEN VAN KNIE EN ONDERBEEN

\subsection{AMPUTATIE VAN HET ONDERBEEN \\ 869.1 EXARTICULATIE VAN HET ONDERBEEN (KNIEGE- WRICHT) \\ 869.2 OPNIEUW AANZETTEN VAN ONDERBEEN \\ 869.3 VERBETEREN VAN EEN AMPUTATIESTOMP VAN HET ONDERBEEN}

Tabel 36. Operatiecodenummers volgens de "Classificaties van Operaties" betrekking hebbend op beenampuraties, zaals gehanteerd door de S.M.R. en aangestoten ziekeminizen.

Het betreft dus ingrepen, onafhankelijk of deze als hoofd-c.q. primaire dan well als neven- c.q. secundaire operatie werden verricht.

Onder hoofdingreep c.q. primaire operatie wordt verstaan een ingreep, die primair een amputatie ten doel had. Neveningreep c.q. secundaire operatie betekent dat de amputatie een secundair gevolg was van een andere (primaire) ingreep.

Uit tabel 37 blijkt dat een differentiatie van amputaties als deel van de ingrepen alleen voor Nederland werd opgegeven (859.0 en 869.0). Het gevolg

*G.H.I.: Geneeskundige Hoofdinspectie. 


\begin{tabular}{ccc}
\hline jaar & 859.0 & 869.0 \\
\hline 1971 & 91,51 & 85,12 \\
1972 & 91,31 & 84,23 \\
1973 & 91,86 & 87,04 \\
1974 & 89,37 & 83,90 \\
1975 & 90,90 & 84,48 \\
1976 & 92,04 & 84,19 \\
1977 & 91,52 & 85,33 \\
\hline
\end{tabular}

SMR UTRECHT aso/im/250179

Tabel 37: Aandeel code 859.0 respectievelijk 869.0 in het geheel van 859 c.q. 869 (hoofd + nevenoperaties, totaal Nederland).

hiervan is dat cijfers met betrekking tot aantallen boven- en onderbeenamputaties alleen voor Nederland als totaal in grafiek gebracht kunnen worden. Alle Limburgse cijfers hebben betrekking op de 3-cijferige codenummers 859 en 869 , zonder verdere differentiatie in decimalen.

Elke vergelijking van Limburg ten opzichte van Nederland in de nu volgende grafieken heeft dus betrekking op ingrepen (tabel 34). Ten overvloede zij vermeld dat in alle grafieken de stijgingen zijn berekend over 1971 tot en met 1977 in procenten van 1971.

Bij sommige van de hierna volgende grafieken en berekeningen lijkt ogenschijnlijk geen correlatie te bestaan tussen de gemeten grootheden. Dit zou de indruk kunnen wekken dat er gelijksoortigheid van vergelijkingspunten onderling gesuggereerd wordt, die er in feite niet is. Het beschrijven van het ontstaan van een dergelijke grafiek leek een mogelijkheid om te voorkomen dat deze onjuiste indruk gewekt zou kunnen worden.

In enkele van de grafieken worden op de linker en rechter schaal twee grootheden met elkaar vergeleken in de tijd. Wanneer deze grootheden betrekking hebben op bijvoorbeeld het aantal beenamputaties in Nederland resp. in Limburg dan verhouden deze gegeven grootheden zich overeenkomstig de totalle populatie van Nederland t.o.v. de totale populatie van Limburg op dat moment.

\begin{tabular}{llll}
\hline & & Nederland & Limburg \\
\hline a. Bevolking & 1975 & $13.5 \times 10^{6}$ & $1.038 \times 10^{6}$ \\
b. Leeftijd 65+(relatief) & 1975 & $10.7 \%$ & $8.6 \%$ \\
c. Leeftijd 65+(absoluut) & 1975 & $1.44 \times 10^{6}$ & $0.089 \times 10^{6}$ \\
d. Amputaties $(859.0+869.0)$ & 1975 & 1589 & 98 \\
\hline
\end{tabular}

Tabel 38: Bevolking, relatiete en absolute aantal bejaarden, ouder dan 65 jaar en het totcal aantal beenamputaties $(859.0+869.0)$ van Nederland, resp. Limburg in 1975.

De gegevens vermeld onder a., b. en c. werden ontleend aan het C.B.S. (1976). De gegevens vermeld onder d. zijn af te leiden uit tabel 34 en tabel 37.

Uit deze gegevens volgt dat voor 1975 gold:

De verhouding $\begin{gathered}65 \text {-jarigen en ouder in Nederland } \\ 65 \text {-jarigen en ouder in Limburg }\end{gathered}=\frac{1.44}{0.089}=16.17$. 
Bovenstaande berekende verhoudingsfactor uit tabel 38 werd bepaald woor het jaar 1975. Deze berekening zou voor elk der jaren, in de tijdschaal van de hierna volgende grafieken opgenomen, uitgevoerd kunnen worden. De veranderingen in de verhouding 65 -jarigen en ouder in Nederland $t, 0 . v$ de 65 -jarigen en ouder in Limburg zijn echter verwaarloosbaar klein in het onderzochte tijdvak 1971-1977, waardoor een constante verhoudingsfactor gehandhaafd mag worden voor elk der jaren $1971 \mathrm{t} / \mathrm{m} 1977$.

Dit betekent dat in een grafiek, waarin het totale aantal beenamputaties in Nederland t.o.v. dat in Limburg vergeleken wordt, deze verhoudingsfactor steeds aanwezig is tussen de beide onderzochte populaties.

Uit de gegevens van tabel 34 en tabel $37 \mathrm{kan}$ voor 1975 berekend worden:

\begin{tabular}{llc}
\hline & Nederland & Limburg \\
\hline Aantal beeningrepen $(859+869)$ & 1809 & 112 \\
Aantal beenamputaties $(859.0+869.0)$ & 1589 & 98 \\
\hline
\end{tabular}

Hieruit volgt:

$\begin{aligned} & \text { Aantal beenamputaties }(859.0+869.0) \text { Nederland } \\ & \text { Aantal beenamputaties }(859.0+869.0) \text { Limburg }\end{aligned}=\underset{98}{1589}=16.21$.

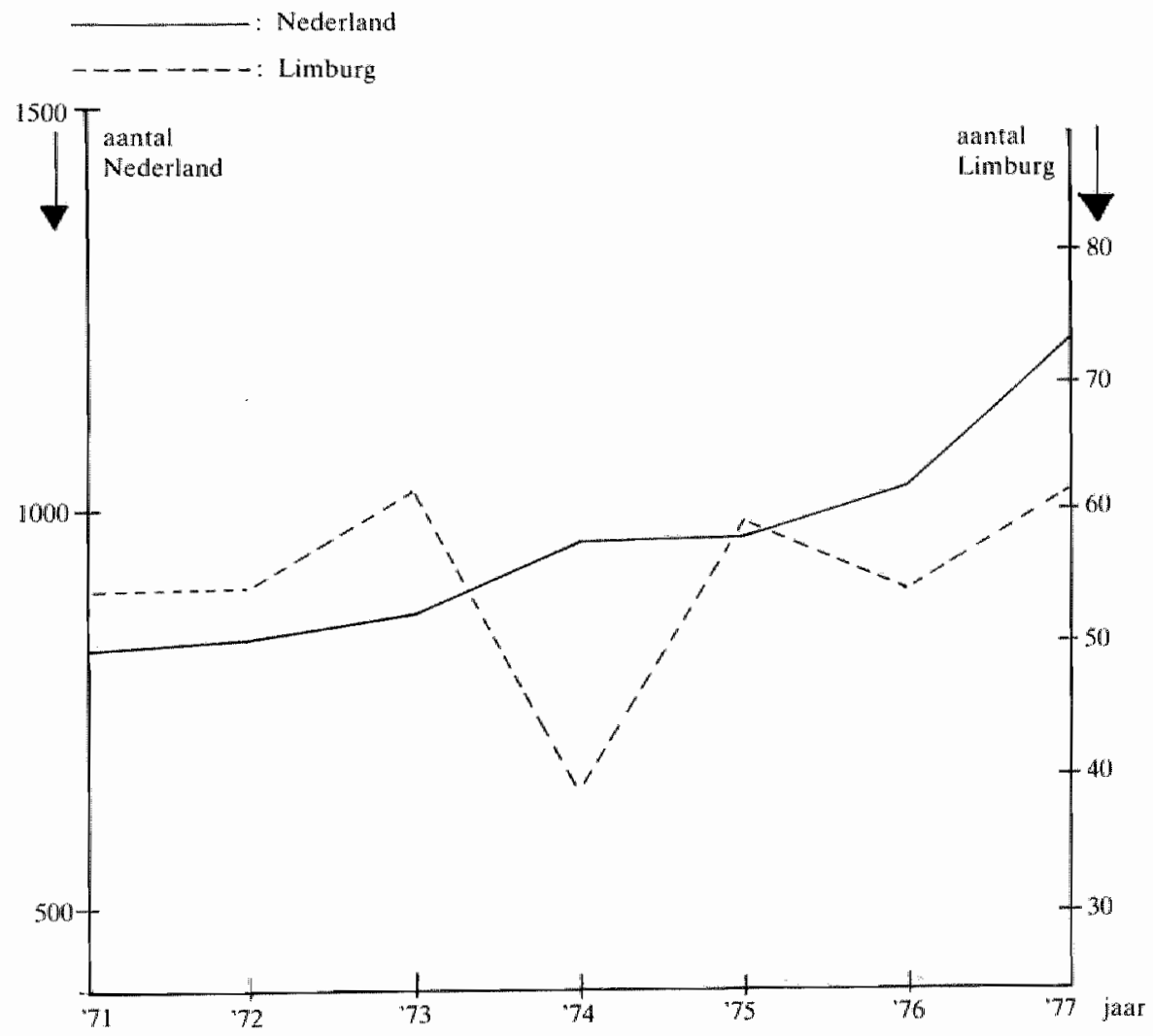

Grafiek 2: Hes relatiene verloop van de frequentie per fatar wan de bouenbeningrepen (859) in Limburg en Nederland. 
Deze verhoudingsfactor correspondeert met de berekende verhouding van 16.17 op grond van de aantallen 65-jarigen en ouder van resp. Nederland en Limburg in 1975.

Grafiek 2 laat het verloop zien van het asantal ingrepen met betrekking tot het bovenbeenniveau in Limburg en Nederind. De doorgetrokken lijn correspondeert met de linker schaalverdeling en geeft het verloop voor Nederland aan. De stippellijn heeft betrekking op de rechter schaalverdeling en geeft het verloop voor Limburg weer.

Men kan vaststellen hoe in de loop van de jaren 1971-1977 voor Nederland een regelmatige stijging optrad, welke in $197742 \%$ hoger lag, vergeleken met 1971. Limburg daarentegen toont een grillig verloop.

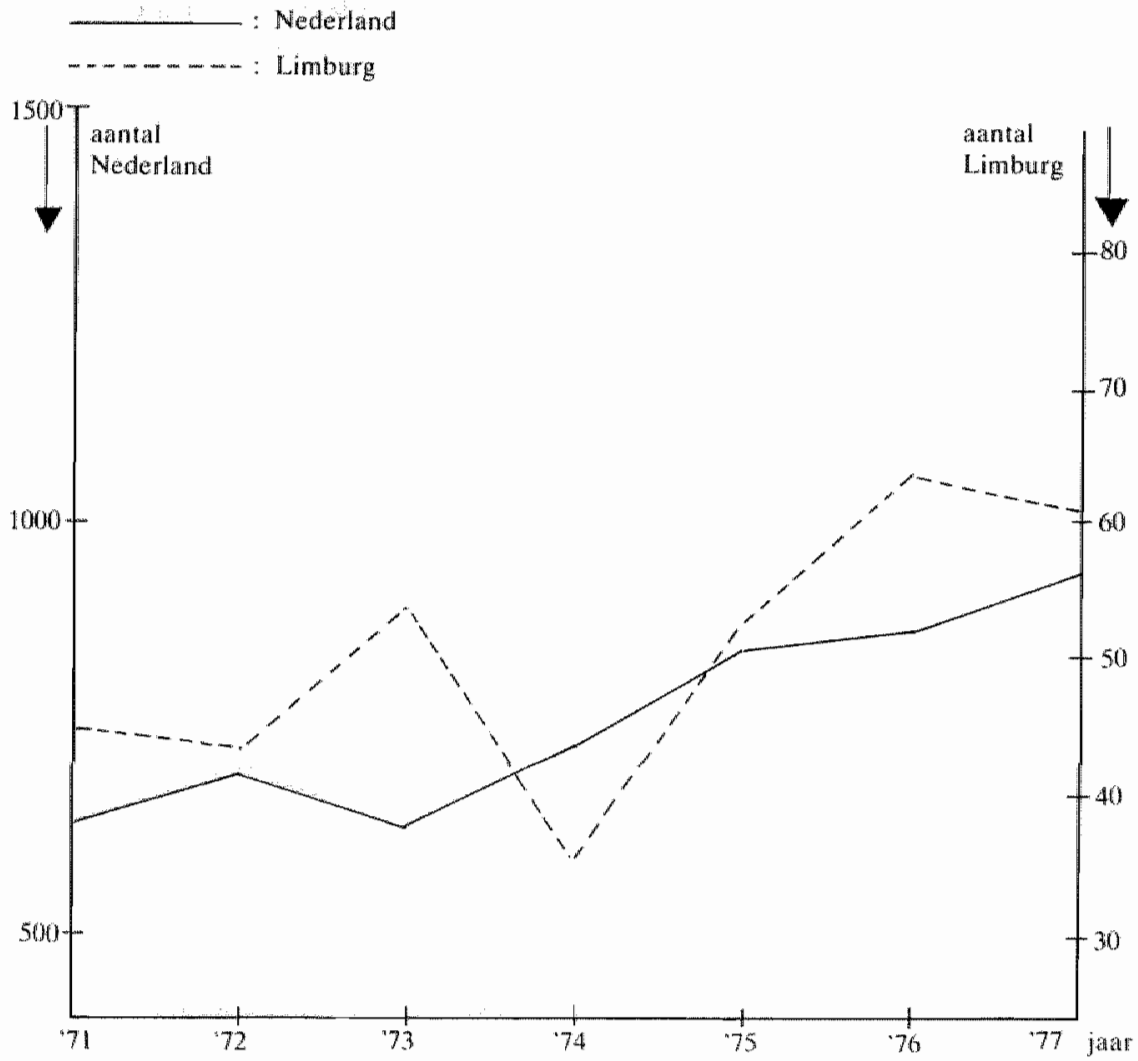

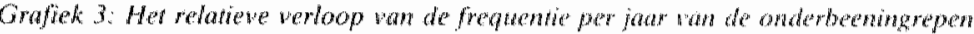
ro60) in Limburg en Nederland.

Grafiek 3 laat het verloop zien van de ingrepen op onderbeenniveau, zowel voor Nederland als Limburg in de jaren 1971-1977. Ook hier correspondeert de doorgetrokken lijn met de linker schaal en de stippellijn met de rechter schaalverdeling, respectievelijk het verloop voor Nederland en Limburg aangevend.

De stijging voor Nederland blijkt regelmatig te zijn en in $197746 \%$ hoger te liggen vergeleken met 1971 . Ook hier weer een grillig verloop van de ingrepen op onderbeenniveau in Limburg. 


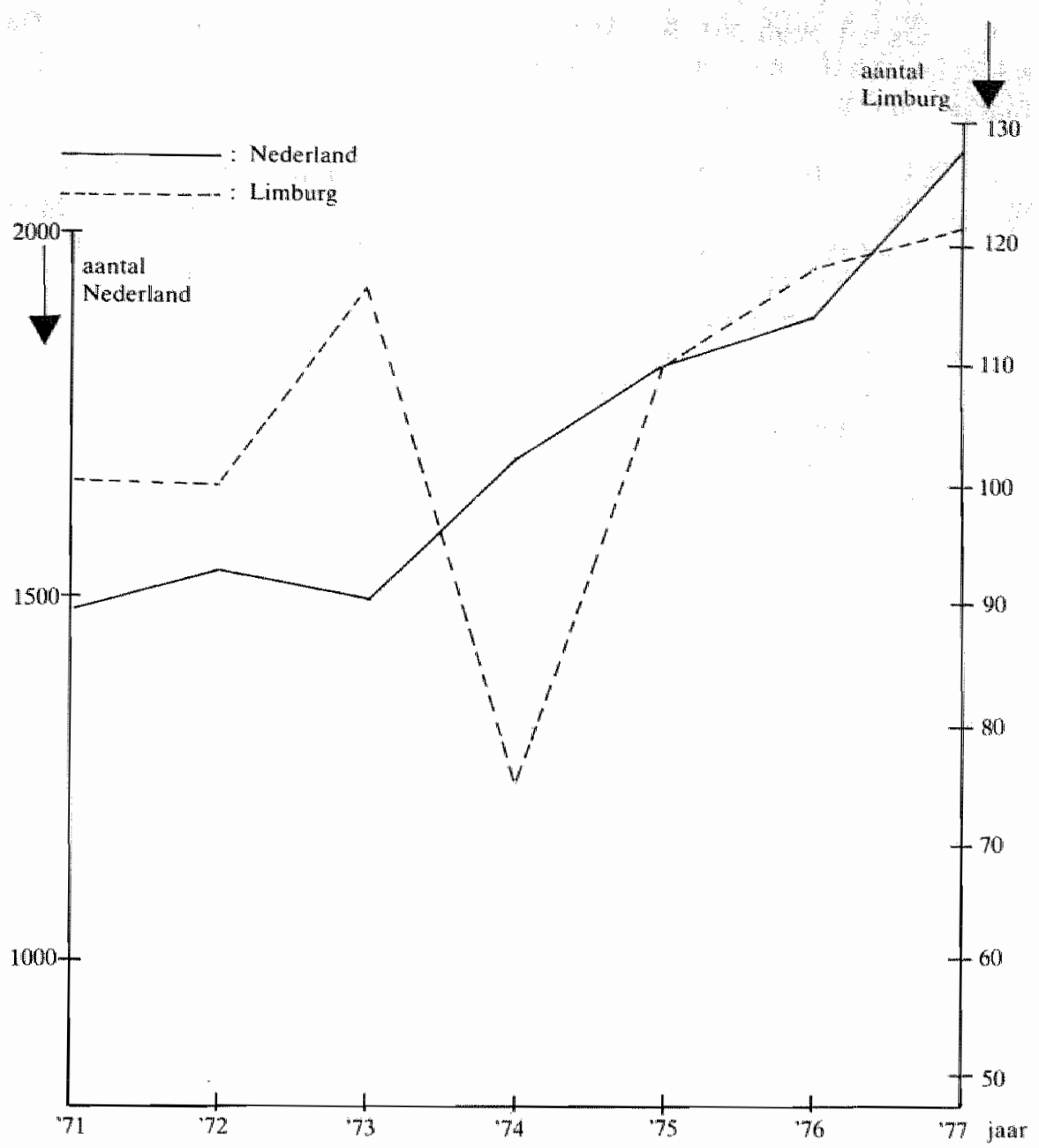

Grafiek 4: Onderbeen en bovenbeenimgrepen $(859+869 \mathrm{j}$ in Limburg en Nederland.

Grafiek 4 is ontstaan door optelling van grafiek 2 en 3 en geeft dus weer het totaal aantal ingrepen op boven- en onderbeenniveau voor Nederland en Limburg in de periode 1971-1977. Evenals in de grafieken 2 en 3 verhouden de beide schalen zich overeenkomstig de totale populatie van Limburg t.o.v. Nederland in 1975.

Dan blijkt dat Nederland een regelmatige stijging laat zien met betrekking tot het totale aantal ingrepen van $43 \%$. Dit is iets lager dan het gemiddelde van de som der stijgingspercentages uit de grafieken 2 en 3 , omdat de inbreng van de ingrepen op bovenbeenniveau groter was in de onderzochte periode.

Limburg laat, zoals te verwachten was uit de grafieken 2 en 3, een grillig verloop zien, vooral ten gevolge van de jaren 1973 en 1974. De merkwaardige inzinking in 1974 blijkt volgens gegevens van de S.M.R. op nationaal ziekenhuisniveau een overeenkomstige beweging te tonen (persoonlijke mededeling S.M.R.); met name in de grotere Limburgse ziekenhuizen zou deze goed waarneembaar zijn. 
Evenals wij, heeft ook de S.M.R. geen verklaring voor dit verschijnsel. Na middelen van de jaren 1973-1974 ontstaat echter ook voor Limburg een regelmatige stijging.

Grafiek 5 geeft de verdeling aan van bovenbeeningrepen en beeningrepen in het algemeen. Zoals reeds geconcludeerd werd uit de vorige grafieken, was er een regelmatige stijging voor zowel boven-als onderbeeningrepen aanwezig.

Het aantal van de bovenbeeningrepen blijft voor Nederland vrij constant rond $56 \%$ van het totaal aantal beeningrepen schommelen. Wat Limburg betreft wordt de conclusie van grafiek 4 bevestigd: ondanks het grillig verloop blijft de verhouding van onderbeen- t.o.v. beeningrepen in het algemeen vrijwel constant. In relatie tot Nederland mag gesteld worden dat het aantal bovenbeeningrepen in Limburg in elk van de jaren onder het Nederlandse gemiddelde blijft.

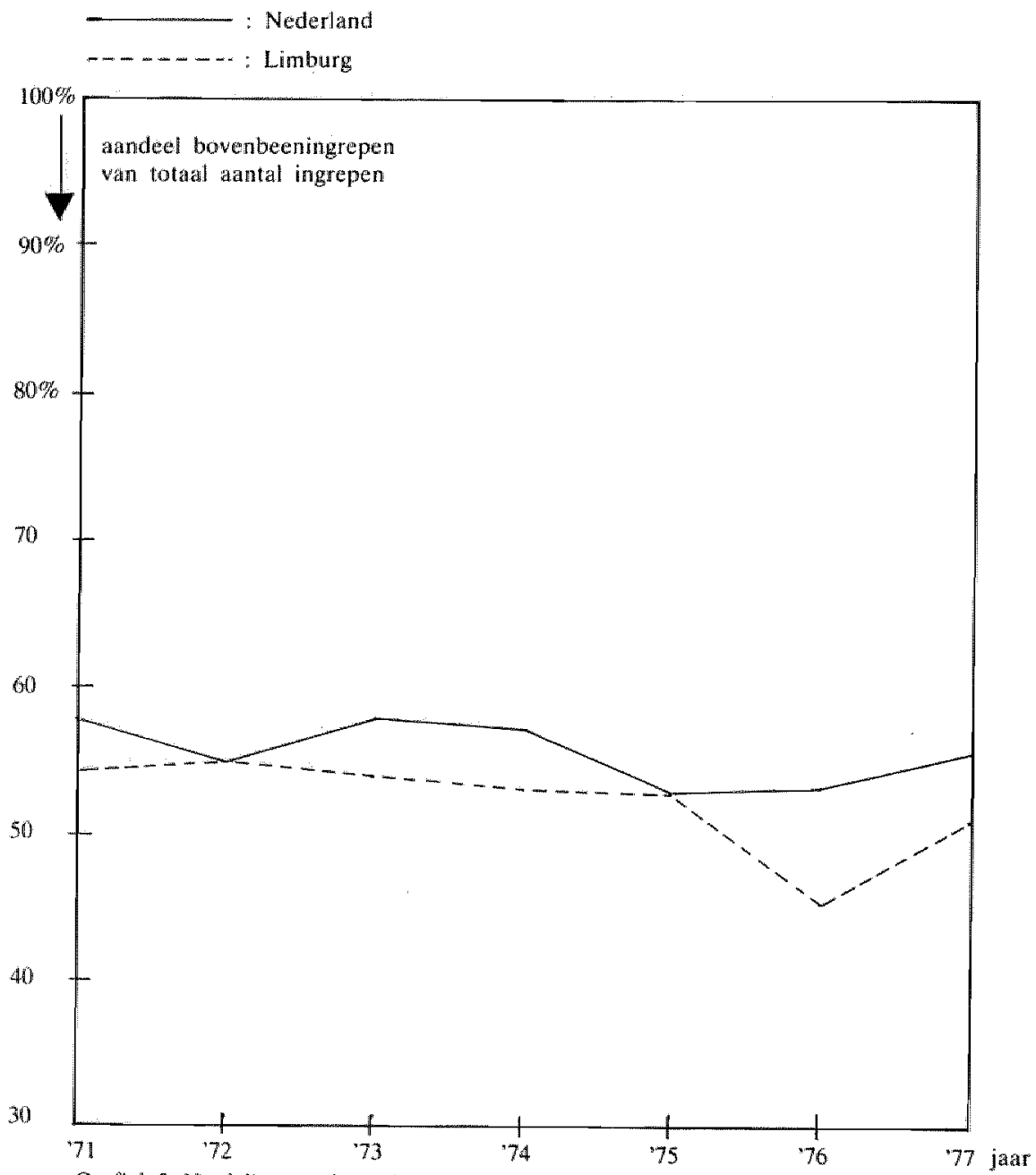

Grafiek 5: Verdeling van bovenbeeningrepen en beeningrepen $(859$ t.ov. $859+869)$ in Limburg en Nederland. 


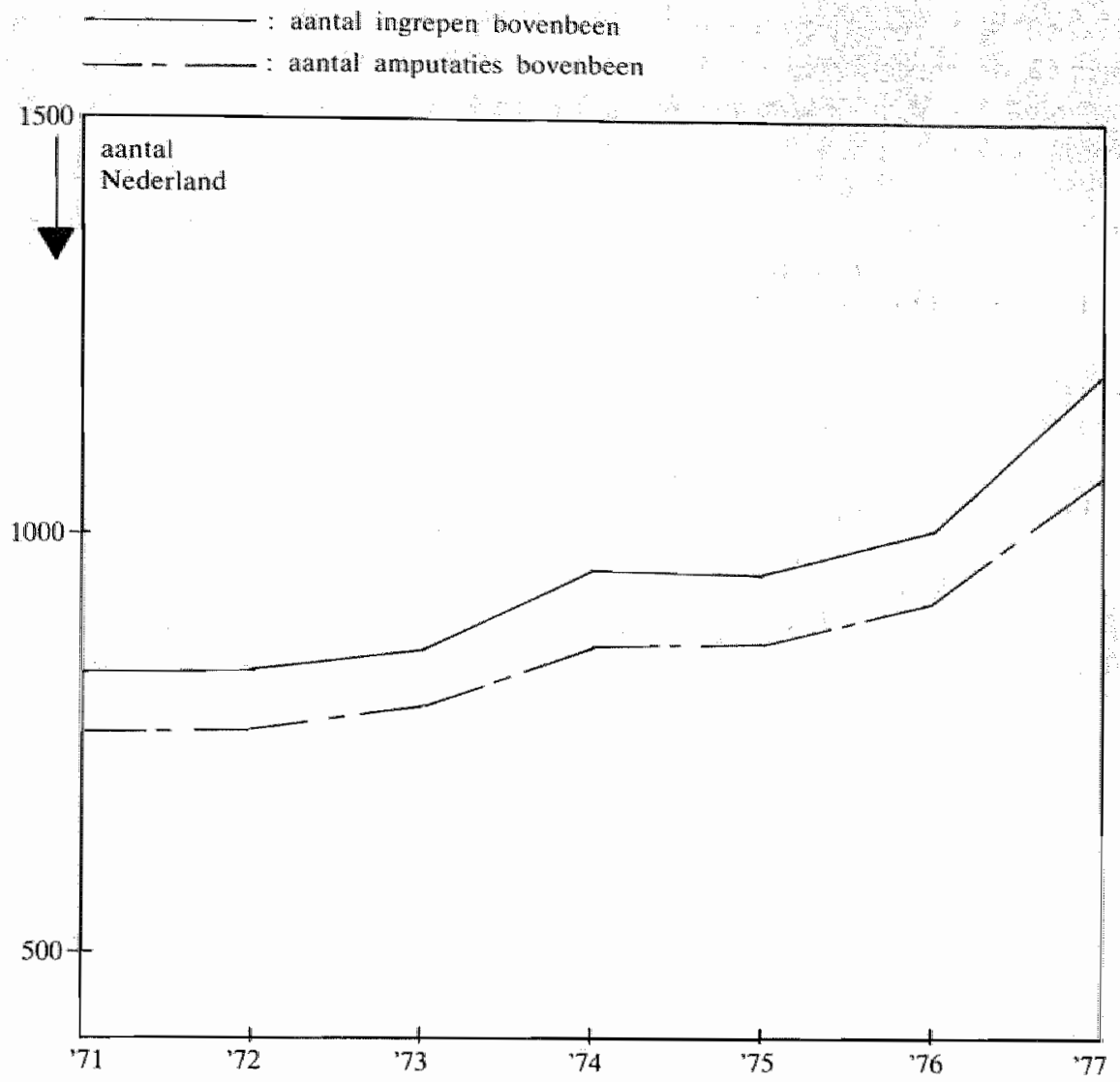

Grafiek 6: Bowenbeeningrepen (859) en boverbeenamputaties (859.0) in Nederland.

De grafieken $6 \mathrm{t} / \mathrm{m} 8$ tonen de relatie tussen ingrepen en amputaties. Duidelijk komt de nauwe wederzijdse betrekking tussen beide tot uitdrukking. Zoals uit tabel 37 is af te leiden is er een relatief gelijkblijvende verhouding tussen ingrepen en amputaties aanwezig van de volgende grootte:

Onderbeeningrepen : onderbeenamputaties $=0.849$

Bovenbeeningrepen: bovenbeenamputaties $=0.912$

Totaal ingrepen : totaal amputaties $=0.880$

Uit het feit dat de relatieve afwijkingen tussen ingrepen en amputaties nagenoeg constant zijn, is het waarschijnlijk dat tendenzen en vergelijkingen, geldende voor aantallen ingrepen, qua aard ook toepasbaar zijn op aantallen amputaties.

Dat wil zeggen dat in de periode van 1971-1977:

- de stijging van bovenbeenamputaties $42 \%$ bedroeg.

- de stijging van onderbeenamputaties $47 \%$ bedroeg.

- de stijging van het totaal aantal amputaties $44 \%$ bedroeg. 
Grafiek 9: Ter controle van het gestelde bij de grafieken $6 \mathrm{t} / \mathrm{m} 8$ is in deze grafiek de verdeling tussen bovenbeen- en beenamputaties in het algemeen aangegeven, Vergelijking met dezelfde grafiek voor ingrepen (grafiek 5) levert, zoals verwacht, geen nieuwe gezichtspunten.

Het is te verwachten dat de stijging van het aantal amputaties volgens grafiek 8 ten volle voor rekening komt van de groep bejaarden (65 jaar en ouder) van de Nederlandse bevolking.

Uit een publicatie van Rouwens (1978) volgt voor bovenbeenamputaties:

1971: $75.3 \%$ van het totaal aantal beenamputaties betrof bejaarden. 1975: 78.5\% van het totaal aantal beenamputaties betrof bejaarden.

De laatste jaren tenderen publicaties in de Westerse wereld naar $80 \%$ of meer. (Murdoch 1977).

Voor de veiligheid wordt het aandeel van de bejaarden in de hierna komende berekeningen en grafieken constant verondersteld op $75 \%$. Het aantal bejaarden stijgt overigens zowel in absolutie zin alsmede als aandeel van de totale Nederlandse bevolking.

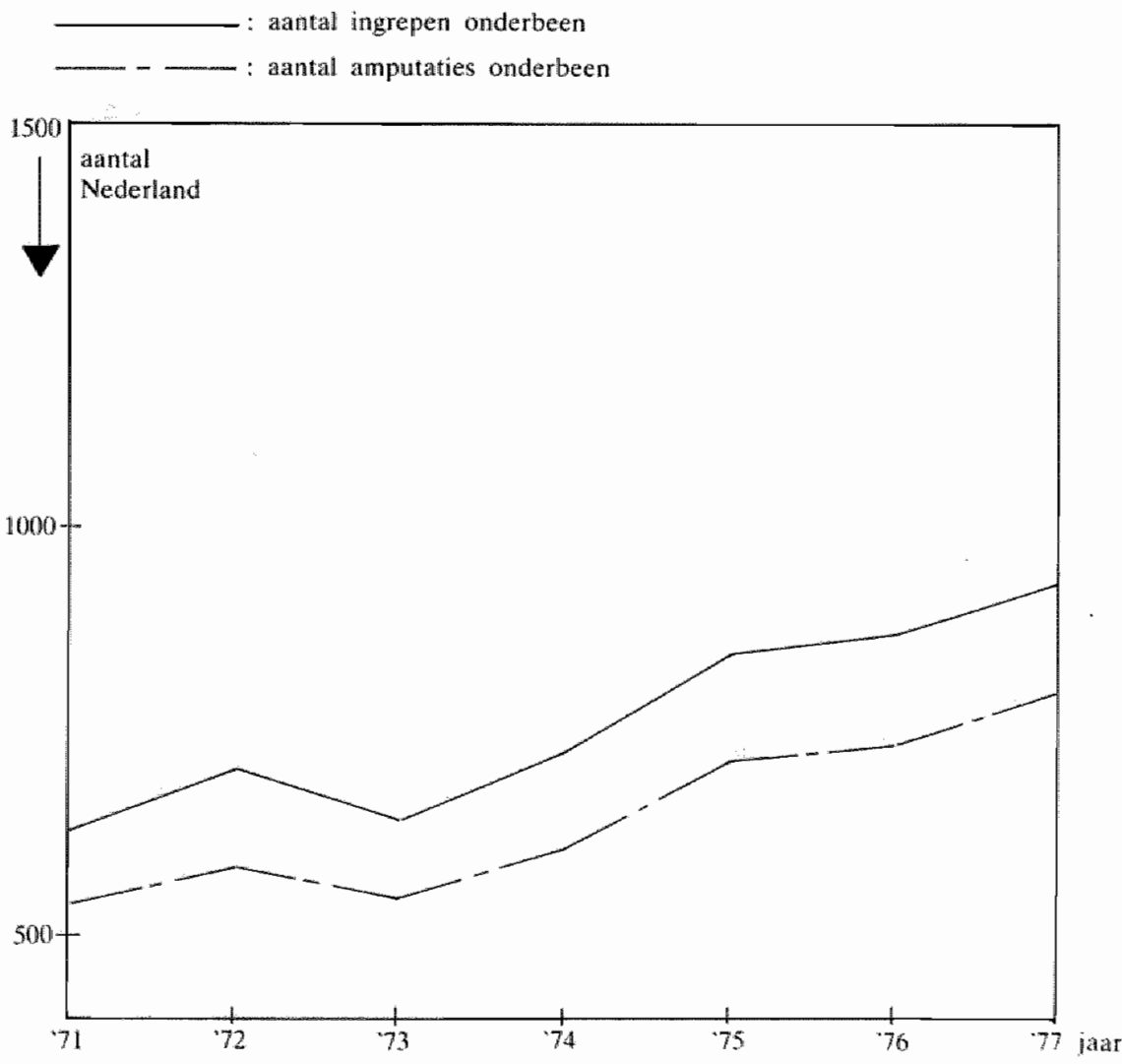

Grafek 7: Onderbeeningrepen (869) en anderbeenamputaties 1869.0 in Nedertand 


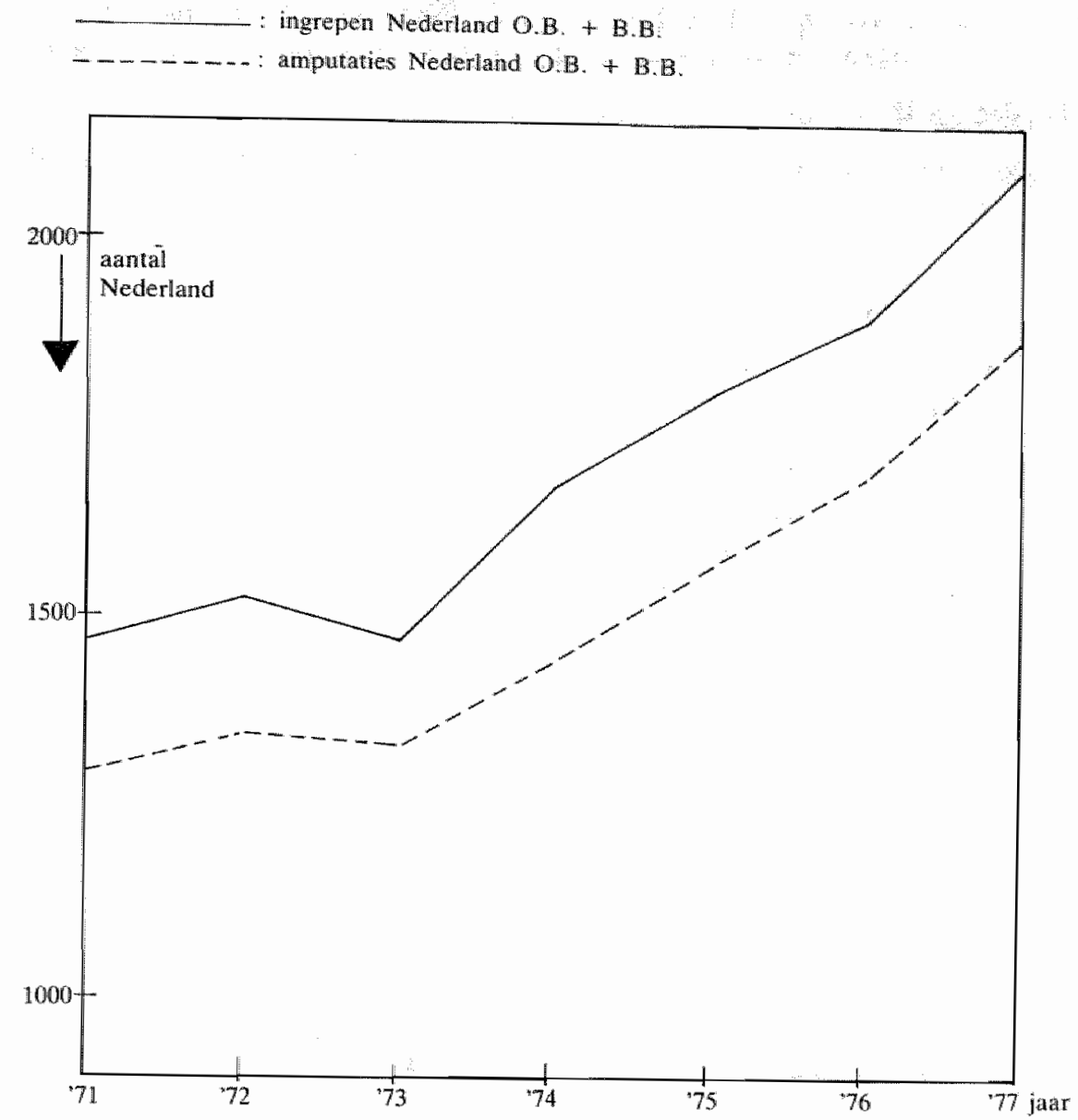

Graftek 8: Boven-en onderberningrepen $(859+869)$ en boven-en onderbeenamputaties $(859.0+809.0)$ in Nedertand.

\begin{tabular}{|c|c|c|c|c|}
\hline & $\begin{array}{l}\text { A. Adntal 6.5-jarigen } \\
\text { en ouder }\end{array}$ & $\begin{array}{l}\text { b. Aantal beethamputaties. } \\
(859.0+869.0) \\
\text { un Nederland }\end{array}$ & 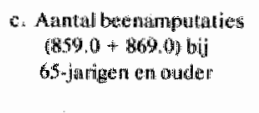 & 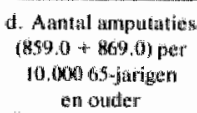 \\
\hline 1971 & 1.339 .620 & 1309 & 982 & 7.3 \\
\hline 1972 & 1.370 .750 & 1355 & 1016 & 7.4 \\
\hline 1973 & 1.395 .269 & $|34|$ & 1000 & 72 \\
\hline 1974 & 1.421 .953 & 1464 & 1098 & 7.7 \\
\hline 1975 & 1.445 .103 & 1589 & 1193 & 8.2 \\
\hline 1976 & 1.490 .209 & 1661 & 1246 & 8.4 \\
\hline 1977 & 1.502 .342 & 1883 & 1412 & 9.4 \\
\hline
\end{tabular}

Tabel 39: Aantal 65-jarigen en ouder, totaal aantal beemamputaties $(859.0+869.0)$. aantal beenamputaties $(859.0+869.0)$ bij 65 -jarigen en ouder en aantal beenamputaties $(859.0+$ 869.0) per 10.000 65-jarigen en ouder in Nederland over het tijdvak 1971-1977.

In tabel 39 worden getallen, betrekking hebbend op diverse grootheden, weergegeven.

De getallen uit kolom a. zijn af te leiden uit de cijfers van het C.B.S. (1976) vermeld in tabel 1. De getallen uit kolom $b$. kunnen berekend worden uit de SMR-gegevens, vermeld in tabel 34 en 37 . Grafiek 8 geeft deze getallen 
grafisch weer. De cijfers in kolom c., zijnde $75 \%$ van de cijfers uit kolom b, worden in grafiek 10 weergegeven. De cijfers uit kolom d. volgen uit de formule ${ }_{\mathrm{a}}^{\mathrm{c}} \times 10^{4}$.

De toename yan het aantal bejaarden in 1977 , vergeleken met 1971 , bedraagt $1.502 .342-1.339 .620=162.722$.

Dit betekent een stijging van $\frac{162.722}{1.339 .620} \times 100=12.14 \%$.

De toename van het aantal beenamputaties $(859.0+869.0)$ bij 65 -jarigen en ouder in 1977, vergeleken met 1971, bedraagt $1412-982=430$.

Dit betekent een stijging van $430 \times 100=43.8 \%$.

Deze verschillende stijgingspercentages worden weergegeven in grafiek 10 .

Grafiek 10 geeft het verloop aan van het aantal bejaarden langs de linker schaal en het verloop van het aantal amputaties bij bejaarden (gesteld op 75\% van het totaal aantal amputaties) langs de rechter schaal. In verband met onderlinge vergelijking zijn de beide schalen zodanig aangebracht dat de beide lijnen in 1971 op gelijk niveau beginnen.

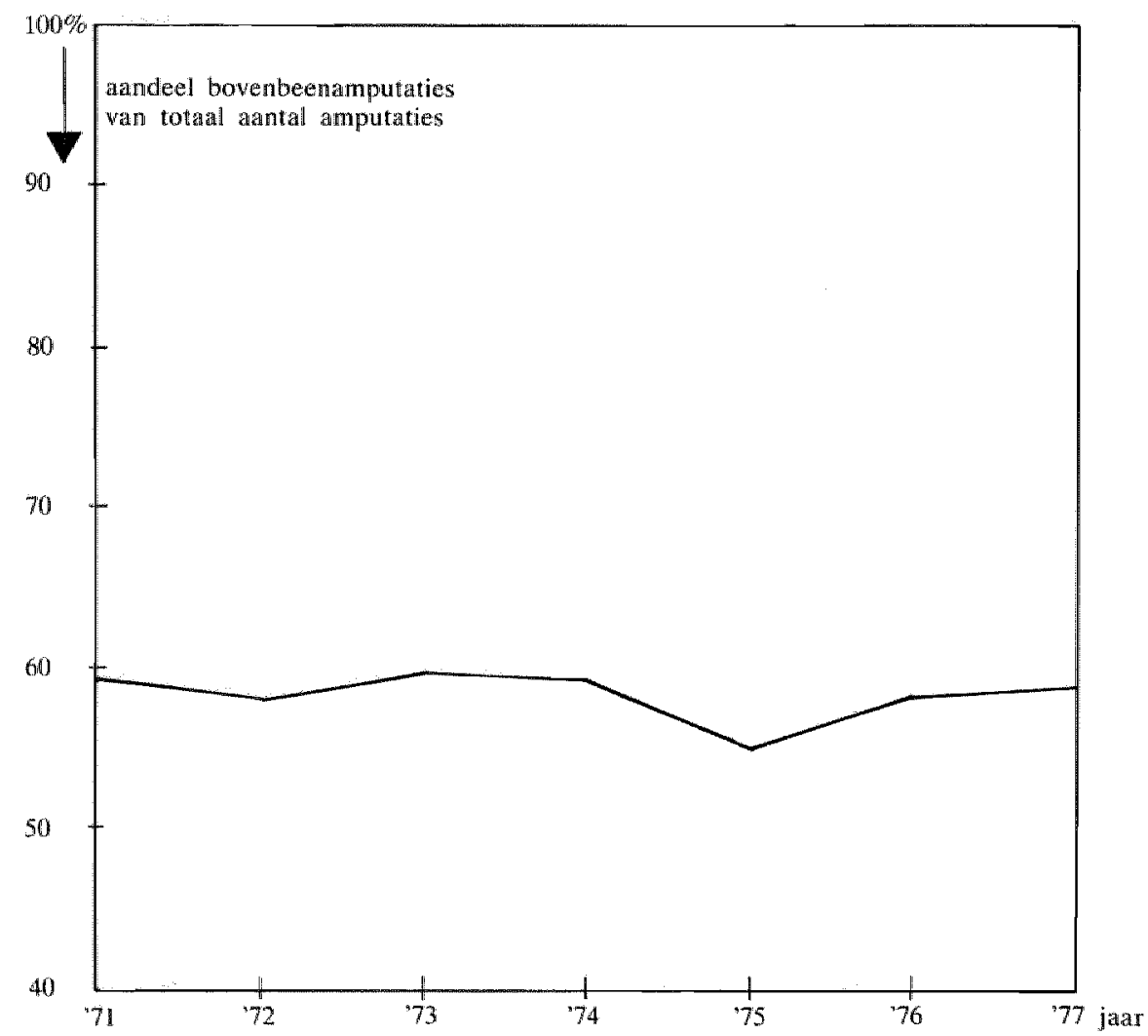

Grafiek 9: Verdeling bovenbeen-ert beenamputaties in her algemeen $(859.0$ r.0.4. 859.0

+869.07 in Nederland. 


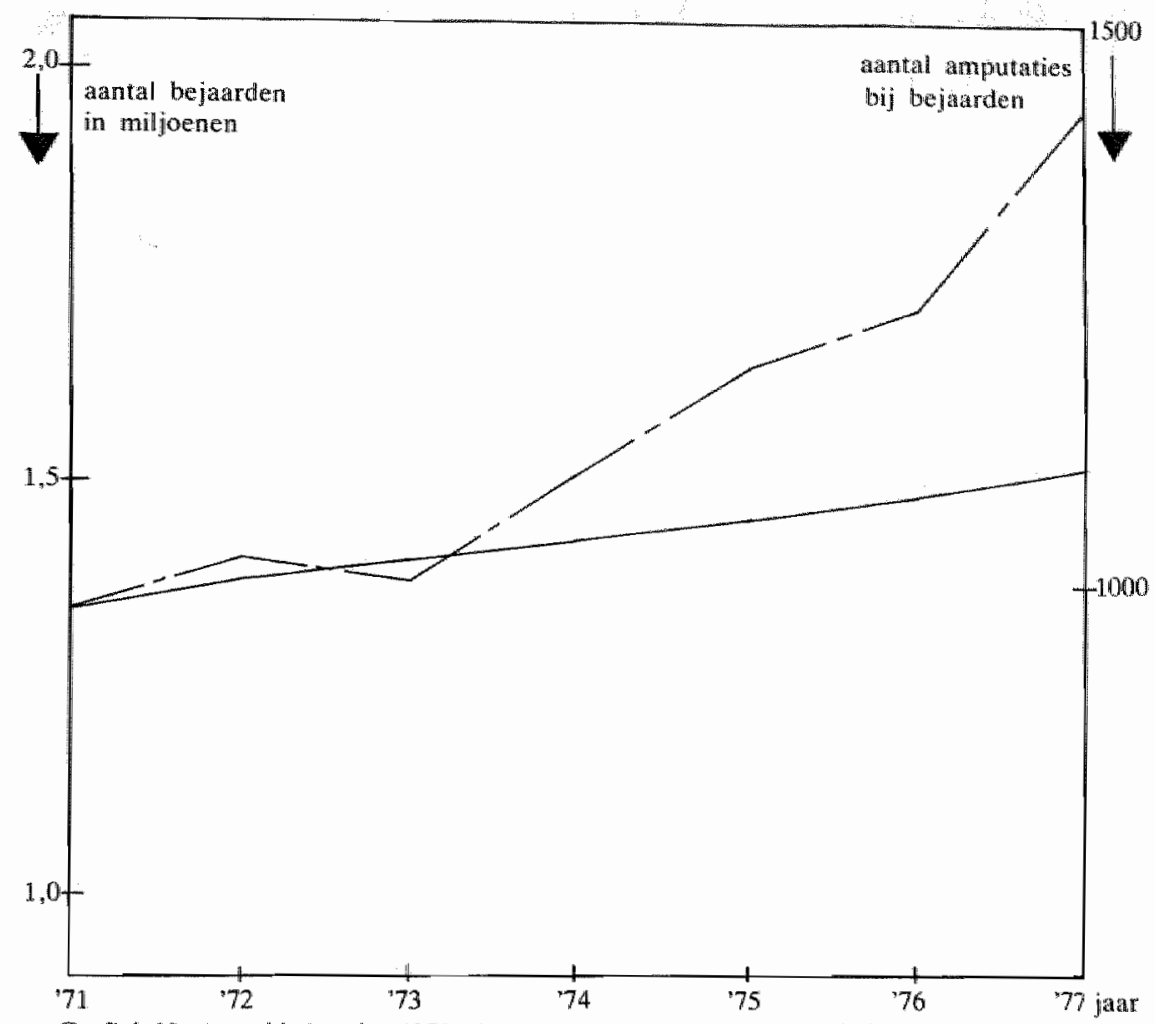

Grafiek 10: Aantal bejaarden 1971-1977 en antal bovenbeen-en onderbeenamputaties $(859.0+869.0)$ bij bejaarden in Nederdand.

Uit deze grafiek blijkt dat sinds 1971 het aantal bejaarden steeg met $12.14 \%$, terwijl het aantal amputaties bij bejaarden steeg met $43.8 \%$. Het aantal amputaties steeg dus relatief beduidend meer dan het aantal bejaarden.

Uitgaande van de veronderstelling dat de komende jaren de gemiddelde levensverwachting van de Nederlandse bevolking weinig zal veranderen, betekent dit dat het risico op een beenamputatie ten gevolge van een degeneratieve ziekte een steeds grotere rol gaat spelen bij de bejaarden.

Om de consequenties van deze discrepantie over langere termijn te tonen, is in grafiek 11 een C.B.S.-voorspelling uit 1976 aangegeven met betrekking tot het aantal bejaarden. van Oosterwijk - Bruyn (1977). Langs de rechter schaal is het aantal amputaties bij bejaarden opgenomen uit grafiek 10 .

Hoogendoorn (1979) stelt: "'Het Centraal Bureau voor de Statistiek (1976) heeft een prognose gemaakt voor de leeftijdsverdeling van de Nederlandse bevolking per 1 januari van het jaar 2000. Aangezien mag worden aangenomen dat het overgrote deel van de dan verwachte bevolking thans reeds leeft, is er, bijzondere invloeden buiten beschouwing gelaten, reden aan deze voorspelling 
praktische betekenis toe te kennen, hoewel enige onzekerheid blift bestaan over het geboortencijfer tussen nu en het jaar 2000 ".

Men kan uit grafiek 11 concluderen dat de stijging van de amputatie-aantallen dermate is dat een voorspelling op lange termijn, uitgaande van het aantal bejaarden, niet mogelijk is.

Om een inzicht te verkrijgen in de bijdrage aan de stijging van het aantal amputaties is in grafiek 12 uitgezet het aantal amputaties per 10.000 bejaarden.

De gegevens, waaruit deze grafiek is samengesteld, kan men terugvinden in tabel 39 , kolom d. Vastgesteld kan worden dat per 10.000 Nederlandse bejaarden de toename van het aantal beenamputaties $(859.0+869.0)$ bij 65 -jarigen en ouder in 1977, vergeleken met 1971 , bedraagt: $\begin{gathered}9,4-7,3 \\ 7,3\end{gathered} \times 100=29 \%$.

De conclusies uit de grafieken 10,11 en 12 zijn belangrijk, wanneer we deze relateren aan de situatie in Limburg.

Het Provinciaal Orgaan Welzijnsbevordering Limburg (P.O.W.L. 1978) bericht in november 1978 dat het aantal bejaarden in Limburg tussen 1977 en 1992 met 40.000 zal toenemen, d.w.z. een stijging van 95.000 naar ca. 135.000 bejaarden.

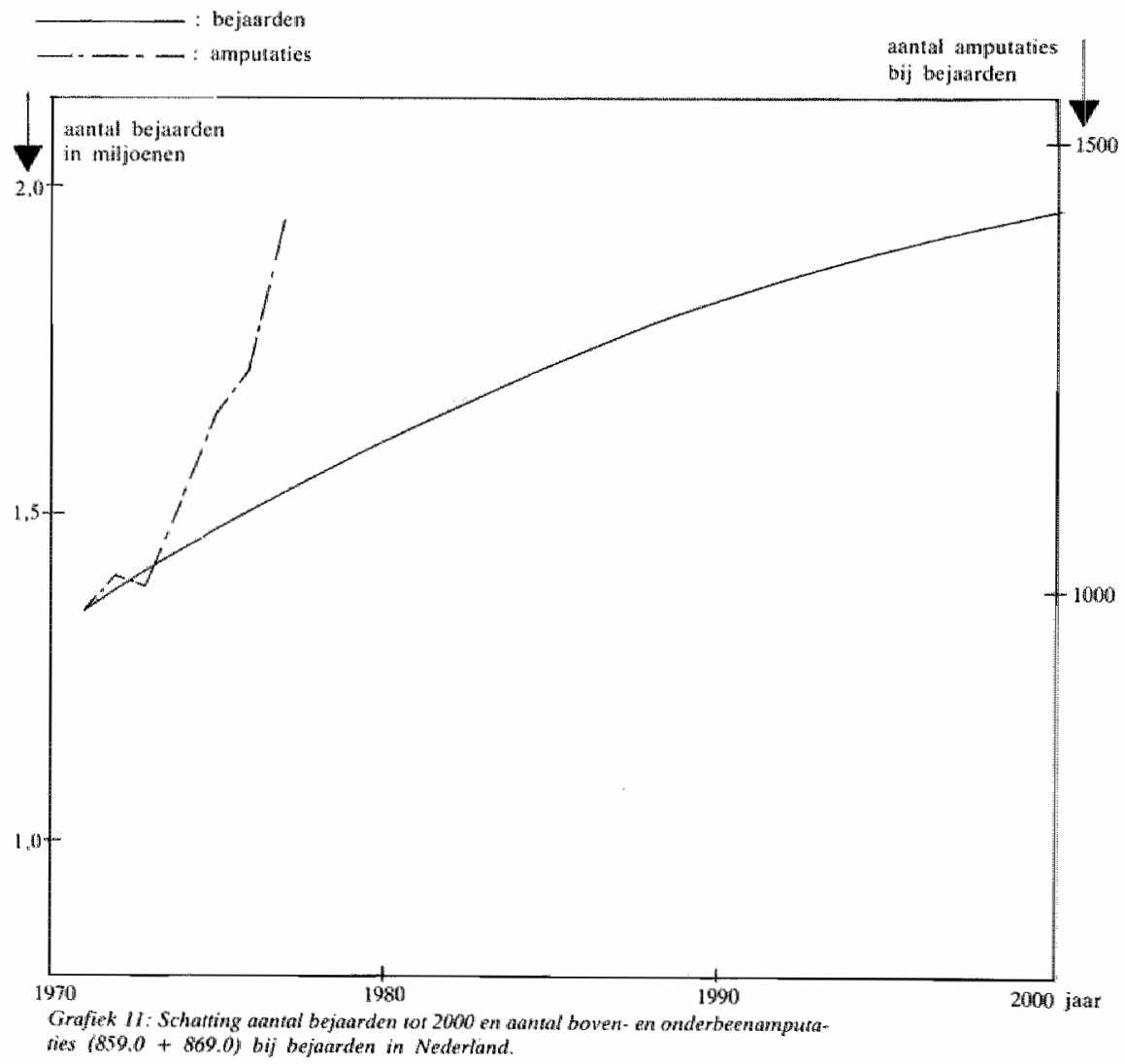


7 antal amputaties

per 10.000 bejarardery

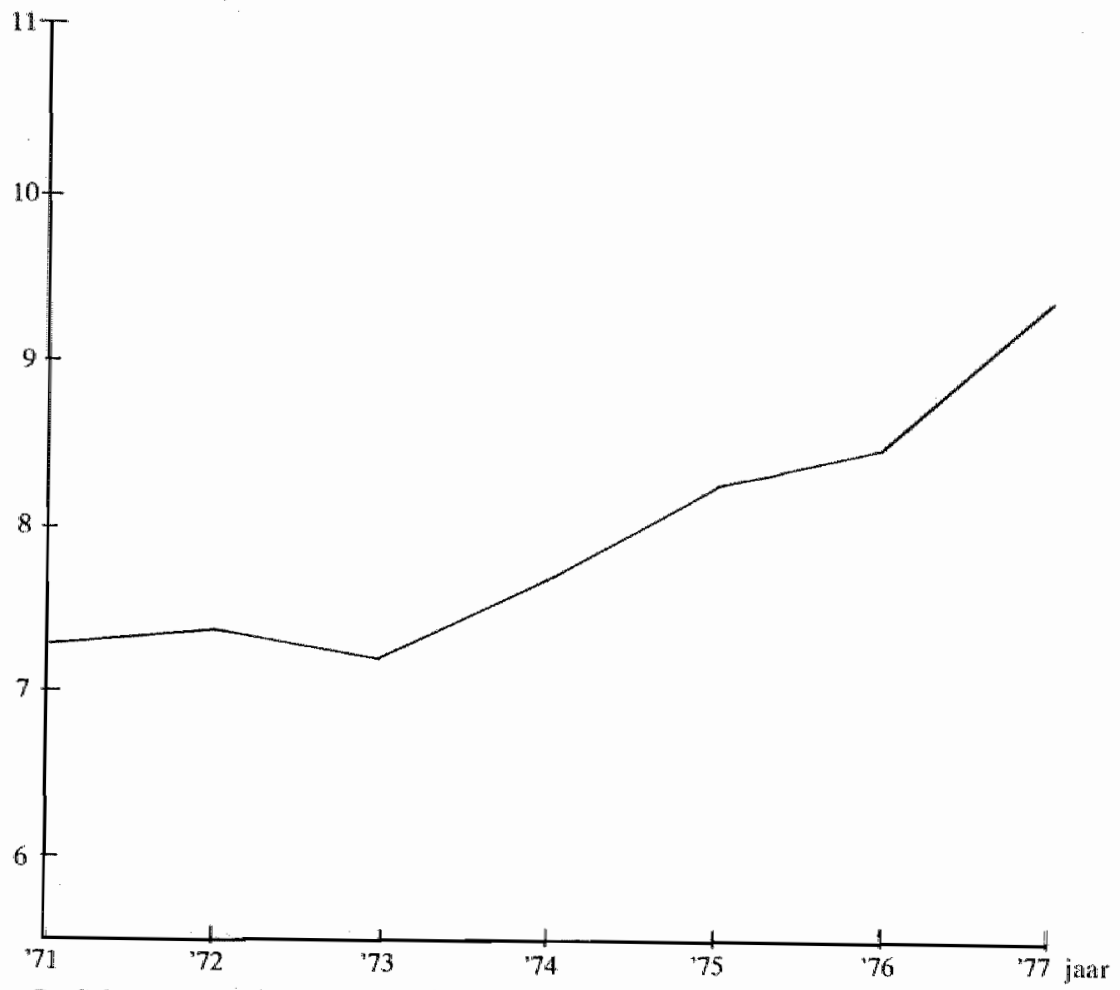

Grafiek 12: Aantal bowen en onderbenamputaties $1859.0+860.0)$ pex 10.000

Nederlandse bejaarden.

"'In de Limburgse mijnstreek is sprake van een wat afwijkende leeftijdsopbouw als gevolg van de met mijnvestigingen samenhangende concentratie van bevolking hoofdzakelijk in de leeftijdsgroep van 20-40-jarigen, en van de gezinsvorming van deze mijnbevolking. Deze afwijkende leeftijdsopbouw werkt reeds enige tijd door in de hoogste leeftijdsgroepen en zal dit ook in de komende tijd nog doen, het is eén van de factoren waardoor de toename van het aantal bejaarden in Limburg in de komende vijftien jaar tweemaal zo groot zal zijn dan in Nederland als geheel". (P.O.W.L. 1978).

\begin{tabular}{lcc}
\hline & $\begin{array}{c}\text { Personen van 65 jaar e.0. } \\
\text { toename in \% 1977.1992 }\end{array}$ & $\begin{array}{c}\text { Personen wan 75 jaar e.0. } \\
\text { toename in } \% \% ~ 1977-1992\end{array}$ \\
\hline Nederland & 21 & 28 \\
Provincie Limburg & 42 & 52 \\
Limburgse Mijnstreek & 55 & 64 \\
\hline
\end{tabular}

Tabel 40: De procentuele toename van het aantal bejaarden en wan het aantal hoog-bejaarden in de periode 1977-1992, voor Nederland, de provincie Limburg en de Limburgse Mimstreek (Oost en West). 
Tabel 40 laat zien dat de toename van het aantal bejaarden, ouder dan 75 jaar, in de periode 1977-1992 voor Nederland 28\% bedraagt, voor Limburg als geheel $52 \%$ en voor de Limburgse mijnstreek zelfs $64 \%$. Het P.O.W.L. heeft deze gegevens gebaseerd op een publicatie van het C.B.S. ("Sterftetafels voor Nederland, afgeleid uit waarnemingen over de periode 1971-1975").

De rijksoverheid beoogt het terugdringen respectievelijk beperkt houden van het aantal bejaarden verblijvend in een verzorgingstehuis. Sedert 1975 wordt van rijkswege als werknorm gehanteerd dat $7 \%$ van de bejaarden aangewezen is op een plaats in een verzorgingstehuis. In werkelijkheid verbleef eind 1974 in Nederland $8.7 \%$ van de bejaarden in een verzorgingstehuis. Voor de provincie Limburg was dit $7.5 \%$. Het P.O.W.L. hanteert niet de werknorm of beter gezegd de streefnorm van de rijksoverheid, maar de behoeftenorm. Een goed houvast daartoe biedt het feitelijk in een verzorgingstehuis verblijvend aantal bejaarden, gespecificeerd naar leeftijd en geslacht in Limburg, einde 1974. Het P.O.W.L. gaat dan voor de berekening van het toekomstig aantal benodigde plaatsen in verzorgingstehuizen uit van de veronderstelling, dat in 1992 een zelfde behoefte aan verzorgingsplaatsen voor bejaarden in tehuizen zal bestaan als de geconstateerde behoefte eind 1974 .

\begin{tabular}{lrrrc}
\hline & & & \multicolumn{2}{c}{ Toename $1977-1922$} \\
\hline Leeftijdsgroepen & 1977 & 1992 & absoluut & $\begin{array}{c}\text { relatief } \\
\text { (in \%) }\end{array}$ \\
\hline 65-69 jaar & 35.101 & 48.823 & 13.722 & 39 \\
$70-74$ jaar & 26.808 & 36.343 & 9.535 & 36 \\
$75-79$ jaar & 17.878 & 25.787 & 7.909 & 44 \\
80-84 jaar & 9.934 & 15.203 & 5.269 & 53 \\
85 jaar e.o. & 5.235 & 9.122 & 3.887 & 74 \\
\hline Totaal 65+ jaar & 94.956 & 135.278 & 40.322 & 42 \\
\hline
\end{tabular}

Tabel 4I: Het aantal bejaarden, onderverdeeld naar leeftijdsgroep, per l januari 1977 en per I januari 1992, in de provincie Limburg.

Tabel 41: Per 1 januari 1992 rekent men voor Limburg op 135.278 bejaarden. Volgens de werknorm van de overheid betekent dit 9.470 verzorgingsplaatsen of wel 7\% van 135.278. Per 1 januari 1978 waren er in Limburg 7.853 plaatsen in verzorgingstehuizen. Tot 1992, d.w.z. binnen 15 jaar dienen er dus 1617 verzorgingsplaatsen bij te komen. Uitgaande van een globaal gemiddelde van 100 plaatsen per verzorgingstehuis, betekent dit dat er tot 199216 nieuwe tehuizen gebouwd moeten worden. De behoefte aan 11.000 verzorgingsplaatsen voor bejaarden in 1992 is $8.14 \%$ van het aantal bejaarden in 1992. De verhoging van $7.5 \%$ feitelijk in 1974 naar $8.14 \%$, berekend in 1992 is vooral het gevolg van de extra toename van de groep hoog-bejaarden. De benodigde 11.000 verzorgingsplaatsen in 1992 betekenen een uitbreiding ten opzichte van 1978 met ruim 3.100 verzorgingsplaatsen of de bouw binnen 15 jaar van 31 nieuwe tehuizen. Het verschil tussen 16 dan wel 31 nieuwe tehuizen wordt veroorzaakt doordat men in het ene geval rekent met een werknorm van $7 \%$ en in het andere geval met een behoeftenorm van $8.14 \%$. Reeds een verschil van 
$1 \%$ betekent ( $1 \%$ van 135.278 bejaarden in 1992) 1.353 verzorgingsplaatsen, dit. is 13 tehuizen meer.

Het P.O.W.L. is bij dit cijfermateriaal, leidend tot prognoses en doelstellingen, bij de haalbaarheid waarvan een vraagteken gezet kan worden, uitgegaan van de bezetting van bejaardenhuizen in de zeventiger jaren in de provincie Limburg. De toename van het aantal bejaarden was de basis van deze berekeningen. Toename, welke de komende jaren in Limburg tweemaal to groot zal zijn vergeleken met de globale toename in Nederland.

Men mag veronderstellen dat bij deze berekeningen het P.O.W.L. niet bekend was met de conclusies uit de grafieken 10, 11 en 12 .

De discrepantie tussen de prognose van het P.O.W.L. en de feitelijke stijging van het aantal geamputeerden in de jaren 1972-1977, waarmee het P.O.W.L. geen rekening heeft kunnen houden, zijn de reden geweest om op een andere plaats in deze studie te stellen dat we een keuze dienen te maken tussen het bouwen van steeds meer bejaarden- en verpleeghuizen of het streven naar een regionale, andere behandeling c.q. revalidatie van geamputeerden.

Deze cijfers onderstrepen op macroniveau het belang van de ontwikkeling, waarbij de chirurg, die in het verleden zich nauwelijks bewust was van de problemen rond een geamputeerde, nu zeer nadrukkelijk uitgenodigd wordt de eerste schakel te willen zijn in de revalidatieketen van een te amputeren patiënt (Amputation can and should be regarded as part of a rehabilitation process).

Voorts onderstrepen deze cijfers op macroniveau eveneens de consequenties van een optimaal beenamputatiebeleid bij bejaarden waartoe kan bijdragen de met opzet uitgebreide behandeling van de Syme-exarticulatie en de exarticulatie door het kniegewricht.

Voor- en nazorg krijgen in het licht van bovenvermeld cijfermateriaal een apart karakter.

Zelfs in revalidatiekringen werd en wordt revalidatie van geamputeerden soms nog gezien als iets dat nauwelijks meer is dan een prothesetechnische zaak.

Fundamenteel wetenschappelijk onderzoek van de problemen rond een geamputeerde medemens, uitbreiding van bestaande orthopaedische werkplaatsen, opleiding van meer deskundig personeel in andere disciplines zoals fysiotherapie, ergotherapie en maatschappelijk werk, zijn uitermate urgent geworden.

Irrelevant is de vraag wie kan of mag amputeren. Irrelevant is eveneens de claim van hen, die revalidatie van geamputeerden als horend tot hun vakgebied opeisen.

Relevant is alleen het willen verstaan van deze problemen en het consequent hiernaar willen handelen, ongeacht de professie van hen die zich tot de revalidatie van geamputeerden geroepen voelen, vooropgesteld het functioneren als een effectief multidisplinair amputatieteam. 


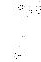




\section{Epiloog}

De geschiedenis met betrekking tot de amputatie van de onderste extremiteit laat zien hoe, door de eeuwen heen, steeds andere aspecten aandacht kregen, afhankelijk van nieuw verworven inzichten of andere doelstellingen. Aanvankelijk bedoeld om leven te redden bleek amputatie vaak een letale procedure ten gevolge van sepsis of exitus door bloedverlies. Zolang men onkundig was omtrent het bestaan van micro-organismen, werd de snelheid waarmee een amputatie plaatsvond maatgevend voor een mogelijk succes. Paré en Larrey zijn exponenten van dit tijdvak.

In de 19 de eeuw ging men de haemostasis beter beheersen. Nadat asepsis en antisepsis het terrein van wereldwijde onderzoekmethoden waren geworden raakte de chirurg steeds meer vertrouwd met een aseptische werkwijze. De moderne anaesthesie, geboren in dezelfde eeuw, maakte snel opereren minder noodzakelijk. Hierdoor onstond de mogelijkheid nieuwe operatietechnieken te ontwikkelen met meer aandacht voor het bewaren van vitaal weefsel. Lister en Syme mogen voor deze volslagen andere benadering als pioniers worden genoemd.

Mogelijk in medische kring minder opgemerkt, maar daarom zeker zo belangrijk was het onstaan van "gelede prothesen". Ambroise Paré heeft hier veel aan bijgedragen. Verbeterde prothesetechnieken hebben langzaam de combinatie amputatiestomp - prothese als functionele entiteit naar voren gebracht. Ten nauwste hangt hiermee samen de aandacht voor amputatieniveau's en amputatietechnieken.

Het doorbreken van een oud stramien was niet altijd eenvoudig. Illustratief hiervoor is de legerorder voor de Duitse Geneeskundige Dienst in de Tweede Wereldoorlog, die, op aandringen van Kirschner, het klakkeloos toepassen van de schemata van Zur Verth c.s. ongedaan moest maken. Alleen de "emergency case" geeft de chirurg de plicht te opereren "An der Stelle der Not", wanneer andere operatieve maatregelen geen soulaas meer bieden." An der Stelle der Wahl" opereren is dan niet geindiceerd, omdat een correcte amputatietechniek, met de daarvoor noodzakelijk langere narcoseduur ongewild kan bijdragen tot een infauste afloop.

Terecht zij opgemerkt dat deze uit oorlogsomstandigheden geboren zegswijzen, ook gelden voor het groeiend individu. De chirurg die dan ook het "An der Stelle der Not" principe hanteert, mag zich verzekerd weten van de waardering van een amputatieteam en de dankbaarheid van de patiënt. De chirurg, zulks doende, heeft blijk gegeven zich bewust te zijn van zijn grote verantwoordelijkheid die hij draagt als eerste man in een revalidatieproces.

Chirurgen als Berlemont, Burgess, Murdoch, Marquardt, Jansen, Vitalie en Dederich hebben in de zestiger jaren een ommekeer teweeggebracht in amputatietechnieken en prothesiologie. Hefboomvraagstukken werden verdrongen door circulatiefysiologie van de amputatiestomp, anticiperend op het te verwachten functioneren van het mens-machine systeem. 
Rond $80 \%$ van alle amputaties vindt momenteel in de Westerse wereld plaats op grond van een vaatlijden, d.w.z. op grond van een degeneratieve ziekte, die in de meeste gevallen de bejaarde mens als slachtoffer heeft. In verband daarmee werd in deze studie aan het mens-machine systeem de milieufactor toegevoegd. Waardering, respect voor de bejaarde, omschreven in de Latijnse Caritas, vechten om voorrang waar tevens economische motieven, verantwoorde gezondheidszorg of betere efficiency van de binnen deze gezondheidszorg na te streven maatregelen, aan deze competitie hun aandeel leveren.

Binnen dit mens-machine-milieu systeem blijkt elke geamputeerde, afhankelijk van zijn leeftijd, geconfronteerd te worden met bepaalde problemen.

Revalidatie van geamputeerden is niet een prothesetechnische zaak alleen. Revalidatie van een geamputeerde is te ordenen naar de drie pijlers van het mens-machine-milieu systeem, die op elkaar afgestemd dienen te worden en die niet los van elkaar mogen worden gezien. Dit is te realiseren in een multidisciplinaire benadering, waar frequente en intensieve interdisciplinaire contacten bestaan. Administratief-organisatorisch gescheiden van het R.C.H.-amputatieteam, maar nauw ermee samenwerkend ten behoeve van het mens-machine-milieu systeem is in de afgelopen jaren het R.T.H. gerealiseerd. De technici van het R.T.H., met aan het hoofd een werktuigbouwkundig ingenieur, stellen kennis en kunde inzake technische en mechanische problemen, materialen, vormgeving, electronica en computertechniek in dienst van de revalidatiegeneeskunde. De technicus, zo men wil de medisch ingenieur, heeft de know-how met betrekking tot de fabricage van hulpmiddelen en aanpassingen voor gehandicapten. Zo kan hij, werkend binnen de Lucasstichting voor Revalidatie, inspelen op de problemen waarop het amputatieteam van het R.C.H. stuit bij het realiseren van aanpassingen, individudan wel milieugebonden. Na realisering van hulpmiddelen kan evaluatie plaatsvinden door het amputatieteam. Deze teamgebonden benadering waardoor de technicus "gevoed" wordt met gegevens vanuit de kliniek en vanuit het milieu van de geamputeerde, kan alleen maar ten goede komen aan de in het revalidatiecentrum opgenomen patiënten.

Dit geldt evenzeer voor centra als het A.C.H. of L.C.H., de V.I.A. of het C.B.H., welke jongste loot van de Lucasstichting (althans op dit moment) nog zijn nut zal bewijzen.

In deze studie werd verantwoording afgelegd omtrent de behandeling van 125 patiënten, die aansluitend aan de amputatie van een of twee der onderste extremiteiten voor revalidatie in het Revalidatiecentrum "Hoensbroeck" werden opgenomen in de periode van juni 1972 - juni 1977.

De gemiddelde leeftijd van deze groep patiënten was 54.6 jaar; de gemiddelde leeftijd van de mannelijke patiënten was 46.9 jaar, van de vrouwelijke patiënten was deze 62.4 jaar. De verhouding tussen mannen en vrouwen was ongeveer $2: 1$, hetgeen overeenkomt met de verhouding zoals deze momenteel in de Westerse wereld bestaat met betrekking tot geamputeerden van de onderste extremiteit.

De opname vond plaats zonder selectie van de kant van het R.C.H., behalve wanneer er sprake was van dementie, welke reeds bestond voordat de ziekte, welke tot amputatie voerde, manifest werd. Indien revalidatie een leerproces 
is, dan is dit een te zware opgave voor een demente patiënt. Afgezien van deze absolute contra-indicatie, gaat het amputatieteam van het R.C.H. uit van de premisse, dat elke te revalideren patiënt na amputatie de kans moet krijgen; om zelf aan den lijve te ervaren of revalidatie, welke streeft naar een hoger functioneel niveau, all of niet mogelijk is. Wanneer tijdens de revalidatie mogelijke contra-indicaties aan het licht komen, dan zal het gehele team deze beoordelen. De arts, die geamputeerden behandelt, is niet alléen in staat tot oordelen, waar contra-indicaties kunnen bestaan op een terrein, waar zijn specifieke deskundigheid te kort schiet.

Voordat de opname in het R.C.H. plaatsvond, was er nooit rechtstreeks contakt met de patiënt, behalve in die gevallen waarbij immediate fitting werd toegepast.

Diverse facetten van de revalidatie bij beengeamputeerden worden nader toegelicht, zoals indicatie tot amputatie, prothesekeuze, opnameduur etc. uitmondend in de resultaten met betrekking tot het functioneren als prothesedrager alsmede de huisvesting na ontslag uit het R.C.H.

Op de taak van het maatschappelijk werk, de psychologische dienst en de ergotherapie wordt uitgebreid ingegaan, waarbij de functie van genoemde disciplines in het revalidatieproces wordt aangeduid.

Afzonderlijk werd de groep van 100, op grond van vasculaire insufficiëntie, geamputeerden belicht met als doelstelling het funktioneren met de prothese en de huisvesting na ontslag.

Tenslotte werd voor de gehele groep van 125 patiënten een onderzoek verricht in maart - april 1978 met betrekking tot het functioneren als prothesedrager op dat moment.

20 personen, betrokken bij het onderzoek gedaan in de jaren 1972-1977, waren intussen overleden. Van de nog resterende 105 ex-revalidanten werd vastgesteld dat $84.7 \%$ nog steeds geclassificeerd kon worden als ', gunstig", d.w.z. in de categorie $3 \mathrm{t} / \mathrm{m} 6$ van Vaucher.

Gelet op het feit dat $80 \%$ der revalidanten ouder was dan 50 jaar en ruim $31 \%$ ouder dan 70 jaar, moge duidelijk zijn dat revalideren van geamputeerden een effectvolle zaak kan zijn. De conclusie lijkt gerechtvaardigd dat revalidatie van geamputeerden, met name ook van ouderen boven de 65 jaar, een proces is dat moet worden begeleid door een zodanig gespecialiseerd team van deskundige artsen, psychologen, para-medici en technici, dat dit alleen verantwoord kan gebeuren door concentratie van deze geamputeerden in een daarop ingesteld revalidatiecentrum. Prothesevoorziening en verdere revalidatie kan niet verantwoord gebeuren in de verpleeghuizen, die daarvoor kennis, gespecialiseerde mankracht en outillage ontberen.

Optimale revalidatie naar het mens-machine-milieu systeem is echter alleen mogelijk, wanneer revalidatie niet gezien wordt als een geïsoleerd gebeuren in een revalidatiecentrum. Contacten met het eerste en tweede echelon van de gezondheidszorg zijn onmisbaar gebleken. Revalidatie van een geamputeerde dient aan te vangen vóór de amputatie een feit wordt. De chirurg is de eerste schakell in de gehele revalidatieketen. Samen met de revalidatie-arts in het ziekenhuis dient hij de heelkunde te beoefenen bij te amputeren patiënten, ook wanneer helen niet meer mogelijk is. Een amputatie is weliswaar een destructieve ingreep, maarkan werkelijk desastreus worden voor de patiënt, wanneer 
de chirurg de amputatie alleen maar ziet als het tragische einde van een chirurgisch onhaalbare zaak, en hij nog luistert naar het wachtwoord , haut et tôt!".

Ook ten aanzien van het eerste echelon en het basis-echelon, met name ten aanzien van de kruissverenigingen, zijn de bakens verzet binnen het kader van wijkverpleegkundige zorg woor de geamputeerde.

In Limburg lijkt de wacht afgelost en daarmee het wachtwoord veranderd. Naast de ommekeer van de "haut en tôt " amputatie op bovenbeenniveau naar de onderbeenamputatie met als enig doel ",preservation of the knee joint" (the current problem of the geriatric amputee) zijn ook belangrijk andere amputatieniveau's, die in tegenstelling met het buitenland, in ons land nog te weinig worden gewaardeerd. Hoofdstuk VI en VII behandelden daarom de Symeexarticulatie en de exarticulatie door het kniegewricht, niet alleen als mogelijk amputatieniveau bij bejaarden, maar tevens met belangrijke voordelen, indien toegepast bij adolescenten en volwassenen.

De gevolgen van een veranderende bevolkingsopbouw met de daaruit voortvloeiende problematiek voor geamputeerden werden beschreven in Hoofdstuk VIII. Regilonaal deze problemen het hoofd te bieden lijkt geboden, nu een groot maatschappelijk probleem dreigt te ontstaan. Regionalisatie kan op gang komen wanneer ziekenhuisbesturen, directies en medische staven volledig aan de realisering hun bijdrage willen leveren. Daartoe is het noodzakelijk dat in elk ziekenhuis een revalidatie-arts deel uitmaakt van de medische staf. De rol van deze revalidatie-arts en de onderlinge taakverdeling binnen de medische staf met betrekking tot te revalideren patiënten in het algemeen, dient te worden vastgelegd. Dit geldt ook voor samenwerkingsprocedures met regionale revalidatiecentra.

De problemen, waarmee de geamputeerde geconfronteerd wordt en de hieruit volgende consequenties voor de Nederlandse Gezondheidszorg, vereisen een verandering in therapeutisch handelen, bij een niet te voorkomen verschuiving in de percentages van de leeftijdsgroepen in ons land.

Dat „Hoensbroeck" in dienst van de Limburgse gezondheidszorg al een ,,sterke Huisinghe" zou zijn waarop gepreludeerd werd in Hoofdstuk I, is zeer zeker" een premature uitspraak en zou alleen maar van zelfoverschatting getuigen. De wil en de daadkracht om dit in de toekomst te realiseren zijn wél aanwezig. 


\section{Epilogue}

The history in the development of amputation techniques of the lower extremities clearly indicates how, through the ages, again and again some new aspect claimed the attention, sometimes arising from a newly acquired insight, sometimes from a newly set objective.

If designed to save lives, amputation only too often proved to be a lethal procedure as a result of septicaemia or of loss of blood. As scientists were still ignorant of the existence of micro-organisms, the speed at which an operation could be carried out became the principal measure for success. The surgeons Paré and Larrey are exponents of this period.

In the nineteenth century, the knowledge on haemostasis widened and gradually asepsis and antisepsis became the fields of worldwide scientific research. Surgeons became better informed of and more familiar with the aseptic working method. A new and better anaestesia technique, developed in the same period, made the speed factor a lower necessity in surgery. This offered the possibility to design new amputation techniques with greater emphasis on the conservation of vital tissues. Pioneers of this totally new approach were the surgeons Lister and Syme.

Another very fortunate development, perhaps less noticed in the medical world, was the creation of the articulated limb. The surgeon Paré has played an important part in the development of these aids. Improved techniques in the making of the artificial limb have gradually brought to light the interrelation of amputation stump and technical device and their combined value as one functional entity. The present scientific interest in amputation levels and amputation techniques resulted from this new awareness.

Breaking away from an old pattern was not always easy however. Dederich refers in this respect to a Second World War ordinance issued to the German army hospitals at the express insistence of Kirschner. This ordinance was to put an end to the gratuitous application of the schemata of Zur Verth c.s. and ordered that only emergency cases where all other operative measures could no longer bring a solution, wartanted a surgical intervention ,, An der Stelle der Not". In such a case an intervention ,"An der Stelle der Wahl" would not be indicated as a correct technique with its implicit longer period of anaestesia might well contribute to an infaust outcome.

It may justly be observed that these wartime expressions are still valid today and are applicable in the case of any growing individual. Therefore, the surgeon who holds the principle of ",An der Stelle der Not" will earn the respect of the amputation team and the gratitude of the patient, and gives proof of his awareness of the large responsibility he carries as the first man in a rehabilitation process. 
Surgeons as Berlemont, Burgess, Murdoch, Marquardt, Jansen, Vitalie and Dederich have brought about in the sixties a revolution in the field of amputation techniques and the art of making artificial limbs. Leverage problems were replaced by a physiology based on the blood circulation in the amputation stump, this in anticipation of the becoming functional of the man-machine system.

About eighty per cent of amputation at present carried out in the Western world are caused by vascular deficiencies. In other words, they are caused by a degenerative disease, the victims of which are mostly found among the elderly. And this is where a third factor, the environment, was added to the material of the research on the man-machine system. Acknowledgement of and esteem for the elderly, as recommended in the Latin document "Caritas", rival for priority with other objectives as economic motives, responsible health care and efficiency in health care.

It has become apparent that within the context of the man-machine-millieu system, each amputee is faced with his own particular problems, mostly dependent on his advancement in age. Rehabilitation of the amputee is not a purely technical affair of the artificial limb only. Rehabilitation of the amputee rests on the above-mentioned three pillars which should be attuned to and considered in connection with one another. Such a process demands a multidisciplinary approach and frequent contacts between the different disciplines.

In the Lucas Institute for Rehabilitation a serious attempt is being made to achieve optimal rehabilitation by means of the man-machine-milieu system. Next to the R.C.H. amputation team of longer standing was in recent years introduced the R.T.H. technical team. Both teams are organisationally distinctly separate entities, but they work closely with one another, are mutually supportive and work along the same principles. The specialists of the R.T.H. technical team, headed by a mechanical engineer, put their combined knowhow and experience of mechanical problems, materials, structure, electronics, and computer techniques, in the use of scientific medical rehabilitation. The technical specialist, or in this specific issue, the medical engineer, possesses the know-how related to the manufacturing of medical aids and adjustments for the disabled. He maintains close contacts with the polytechnic schools. His vast resources permit him to apply a high degree of flexibility in his search for the right technical solution to any problem of adjustment, concerning either the individual or the environment, which comes in the way of the R.C.H. amputation team. When the solution has been found and appliances have been put into place, the follow-up and the evaluation rests with the amputation team. The feed-back of their findings to the technical team is of incalculable value and will permit this team to constantly improve their ability for the benefit of all the patients in the Institute. In the meantime other fruitful cooperation patterns have been set up with centres as A.C.H., L.C.H., V.I.A. and C.B.H.

C. B.H., as latest scion of the Lucas Institute will soon become operational.

In this study account was rendered of the treatment of 125 patients, who, 
after the amputation of one or two of the lower extremities were admitted for rehabilitation into Rehabilitation Centre "Hoensbroeck" in the period of June 1972 - June 1977.

The average age of this group of patients was 54.6 years; the average age of the male patients was 46.9 years, of the female patients 62.4 years. The ratio of men to women was about 2 to 1 , which corresponds with the ratio as it exists in the Western World at the moment.

Admittance occurred without selection on the part of R.C.H., except in case of dementia already existing before the disease leading to amputation became manifest. If rehabilitation is a learning process, then it is an unsurmountable task for a demented patient. Apart from this absolute counterindication, the R.C.H. amputation team starts from the premiss that every patient to be rehabilitated must have a chance after amputation to experience if rehabilitation, aspiring to a higher functional level, will be possible or not. When during the rehabilitation process possible counter-indications come to light, then the whole team will appraise them. The doctor who treats amputees, cannot judge on his own where counter-indications can excist in a field in which his specific expertness is lacking.

Before admittance into R.C.H. there was never direct contact with the patient, except in those cases in which immediate fitting was applied.

Various facets of the rehabilitation of leg-amputees are further explained, such as indication of amputation, choice of prosthesis, duration of admission etc., ending up in the results with regard to their functioning as prosthesiswearers as well as their housing after dismissal from R.C.H.

The task of social work, psychological service and ergotherapeutics is elaborately dwelt on, thereby clearly revealing how there are tangent planes among the disciplines mentioned.

The group of 100 amputees on account of vascular insufficiency was separately thrown light upon, with the aim of determining their functioning with their prostheses and their housing after dismissal.

Finally a survey among the whole group of 125 patients was carried out in March - April 1978 with regard to their functioning as prosthesis-wearers at that point in time.

Twenty people, involved in the survey carried out between $1972-1977$, had died in the meantime. Of the remaining 105 ex-rehabilitated persons it could be established that $84.7 \%$ could still be classified in the categories 3 to 6 of Vaucher.

Bearing in mind the fact that $80 \%$ of the rehabilitated persons were over 50 years of age, and over $31 \%$ over 70 years of age, it will be obvious that rehabilitation of amputees can be significant. The conclusion seems justified that rehabilitation of amputees, particullarly of elderly people over 65, is a process which has to be accompanied by such a specialized team of expert doctors, medical assistants and technicians, that it can only be carried out in a responsible way by concentrating these amputees in a specially established rehabilitation centre. Provision of prostheses and further rehabilitation cannot take place in a responsible way in nursing-homes which lack the necesarry knowledge, specialized personnel and equipment. 
However, optimal rehabilitation by means of the man-machine-milieu system is only possible if the rehabilitation process is not looked upon as an isolated activity, confined to a rehabilitation hospital. Regular contacts with the first and second levels of the general health service are indispensable. The actual rehabilitation of the amputee must start before and not after the amputation takes place. The amputator is the first link in the chain of rehabilitation activities. With the rehabilitation physician he should be involved in the care administered to the patient; he must take part in the healing of the patient even if the cure of the ailment is beyond hope. If of necessity a destructive intervention, an amputation may well turn out to be disastrous for the patient if the surgeon sees the amputation only as a tragic end to a complicated surgical problem, and if he still listens to the pass-word "haut et tôt".

Fortunately we may safely state that for the province of Limburg the old guard has been relieved and the pass-word changed. It must be observed however that next to the radical change from the "haut et tôt" amputation at the upper leg level to the lower extremity with as sole objective the preservation of the knee joint (current problem of the geriatric amputee), there are in many countries new and further developments of other levels of amputation, which certainly do not receive sufficient attention in our country. Chapters VI and VII therefore deal with the Syme exarticulation and the exarticulation through the knee joint. These methods are not only considered with regard to the elderly but are also highly recommended for treatment of adolescents and adults.

A distinct aspect of environment is the district nursing care for the discharged amputee and it is certain that viewpoints in health care management and in particular in the boards of medical aid societies have greatlly changed in favour of the amputee.

The consequences of a changing population structure and the specific problems resulting from these changes for the amputee have been described in chapter VIII. As these difficulties tend to grow into grave social problems, it seems indicated to attack them at the regional level. Regionalization is an organizational structure in which all functional entities working in a same and related fields, and in a same region, decide to consult together and to attune their plans and the implementation of these plans to one another. In this their mutual aim should be to achieve optimal results before quantitative results.

In the medical world successful regionalization can be achieved if hospital boards, hospital managements and medical staff are ready to give their full cooperation. For this it is necessary that in each of the hospitals concerned the interrelated functions and tasks be clearly defined, and also that the policy of the attribution of tasks is built up more or less along the same lines. In particular the medical staff will have to develop cooperation patterns and procedures which will make it possible for any medical staff member involved in a rehabilitation process, to give his full contribution, also if he does not belong to the particular hospital in which this process is taking place.

The problems which the amputee is confronted with and their consequences to Dutch Medical Care, require a change in therapeutic treatment, what with an inevitable shift in the percentages of the age-groups in our country. 
Be it allowed to refer here to the remark in chapter I in which it is suggested that "Hoensbroeck" consitutes already a stronghold in the health care of the province of Limburg. To affirm this would certainly be premature and would border upon conceitedness. However, the will and the energy to make the Institute into such a stronghold certainly do exist: 


\section{Epilog}

Die Geschichte der Amputation der unteren Extremitäten zeigt, wie im Laufe der Jahrhunderte immer wieder andere Gesichtspunkte, bedingt durch neu erworbene Erkentnisse oder andere Zielsetzungen, im Mittelpunkt des Interesses standen. Der Zweck der Amputation war zwar, das Leben zu retten, aber trotzdem zeigte sich oft, dass sie eine Behandlungsweise mit tödlichen Folgen durch Sepsis war oder dass sie Exitus durch Blutverlust zur Folge hatte. Da die Existenz der Mikroorganismen noch nicht bekannt war, hing ein möglicher Erfolg in entscheidender Weise von der Geschwindigkeit ab, mit der eine Amputation durchgeführt wurde. Paré und Larrey gelten als hervorstechende Vertreter dieser Periode.

Im 19. Jahrhundert beherrschte man die Hämostasis besser, Asepsis und Antisepsis wurden allmählich zum Feld weltweiter Forschungsmethoden. Der Chirurg wurde immer mehr vertraut mit einer aseptischen Arbeitsmethode. Dank der modernen Anästhesie, die aus dem gleichen Jahrhundert stammt, war schnelles Operieren nicht mehr so wichtig. So entstand die Möglichkeit, neue Operationstechniken zu entwicklen und der Konservierung vitalen Gewebes grössere Beachtung zu schenken. Lister und Syme können als Pioniere dieser völlig andersartigen Auffassung bezeilchnet werden.

Vielleicht im Medizinerkreisen weniger beachtet, aber mindestens ebenso wichtig war die Entstehung von "'gegliederten Prothesen" . Ambroise Paré hat auf diesem Gebiet einen wesentlichen Beitrag geleistet. Verbesserte Prothesetechniken haben allmählich die Kombination AmputationsstumpfProthese zu einer funktionellen Einheit gemacht. Engstens hiermit verbunden ist das Interesse für Amputationsniveaus und für Amputationstechniken.

Es war nicht immer leicht, das alte Muster zu durchbrechen. Bezeichnend hierfür ist der Heeresbefehl an das deutsche Gesundheitsamt im 2. Weltkrieg, das auf Drängen Kirschners der gedankenlosen Anwendung der Schemata von Zur Verth c.s. ein Ende bereiten sollte. Nur der Ernstfall macht dem Chirurgen die Operation "an der Stelle der Not" zur Pflicht, wenn andere operative Massnahmen keine Linderung mehr verschaffen. "An der Stelle der Wahl" zu operieren, ist in dem Fall nicht indiziert, weil eine korrekte Amputationstechnik mit der dafür erforderlichen langen Narkosedauer ungewollt zu einem aussichtlosen Ausgang beitragen kann.

Mit Recht darf behauptet werden, dass diese aus Kriegsverhältnissen stammenden Redensarten auch für das wachsende Individuum gelten. Der Chirurg, der nach dem "an der Stelle der Not"'-Prinzip handelt, kann der Anerkannung eines Amputationsteams und der Dankbarkeit des Patienten gewiss sein. Wenn der Chirurg nach diesem Prinzip handelt, zeigt er, dass er sich der grossen Verantwortung bewusst ist, die er als erster Mann in einem Rehabilitationsprozess trägt.

Chirurgen wie Berlemont, Burgess, Murdoch, Marquardt, Jansen, Vitalie und Dederich haben in den sechziger Jahren eine Wende auf dem Gebiet der Amputationstechniken und der Prothesiologie herbeigeführt. Vorgreifend auf das zu erwartende Funktioneren des Mensch-Maschine-Systems wurden 
Hebelprobleme durch Zirkulationsphysiologie des Amputationsstumpfes in den Hintergrund gedrängt.

Rund $80 \%$ aller Amputationen sind heute notwendig in der westlichen Welt infolge einer Gefässkrankheit, d.h. einer degenerativen Krankheit, deren Opfer in den meisten Fällen ältere Personen sind. Diese Tatsache zeigt, warum in dieser Untersuchung der Faktor "Umwelt" dem MenschMaschine-System hinzugefügt wurde. Anerkennung, Achtung für das Alter wie in der lateinischen Caritas umschrieben, streiten um den Vorrang, wo immer sich auch wirtschaftliche Motive, verantwortliche Gesundheitspflege oder bessere "effiency" der innerhalb dieser Gesundheitspflege erstrebenswerten Massnahmen hineinmischen.

Es hat sich herausgestellt, dass jeder Amputierte, je nach Alter, innerhalb dieses Mensch-Machine-Umwelt-Systems mit bestimmten Problemen konfrontiert wird.

Rehabilitation von Amputierten ist keine rein prothesentechnischen Angelegenheit. Die Rehabilitation eines Amputierten stützt sich auf die obengenannten drei Pfeiler, die aufeinander abgestimmt werden müssen und nicht als Einzelfaktoren betrachtet werden dürfen. Dies ist nur möglich, wenn man von einem fachübergreifenden Standpunkt ausgeht und wenn häufige und intensive interdisziplinäre Kontakte bestehen. In den vergangenen Jahren wurde das R.T.H. gegründet, das zwar auf verwaltungs - organisatorischem Gebiet vom R.C.H. - Amputationsteam getrennt ist, jedoch auf dem Gebiet des Mensch-Machine-Umwelt-Systems eng mit ihm zusammenarbeitet. Die R.T.H.-Techniker unter Leitung eines Machinenbauingenieurs stellen ihr Wissen und Können in bezug auf technische und mechanische Probleme, Materialien, Formgebung, Elektronik und Komputertechnik der Rehabilitationsmedizin zur Verfügung. Der Techniker, so man will, der "medizinische Ingenieur" hat das "know-how" in bezug auf die Herstellung von prothetischen Hilfsmitteln und auf ihre Anpassungen für Körperbehinderte. Er hat enge Verbindungen zu technischen Hochschulen. So kann er, wenn er in der "Lucasstichting voor Revalidatie" arbeitet, auf jene Probleme eingehen, auf die das Amputationsteam des R.C.H. bei der Verwirklichung von Anpassungen stösst, ob sie nun das Individuum oder die Umwelt betreffen. Nach Fertigstellung der Hilfsmittel kann das Amputationsteam diese prüfen. Diese teamgebundene Arbeitsmethode, bei der der Techniker mit Daten aus der Klinik und aus der Umwelt des Amputierten "gespeist" wird, kann den im Rehabilitationszentrum aufgenommenen Patienten nur zugute kommen.

Das gleiche gilt für Zentren wie das A.C.H. oder das L.C.H., die Abteilung V.I.A., oder das C.B.H., die jüngste Gründung (zumindest zu diesem Zeitpunkt) der Lucasstichting, der seinen Nutzen noch unter Beweis stellen muss.

In dieser Untersuchung wurde Rechenschaft abgelegt über die Behandlung von 125 Patienten, die im Anschluss an die Amputation einer oder zwei der untersten Extremitäten zwecks Rehabilitation im Rehabilitationszentrum "Hoensbroeck" in der Periode Juni 1972 - juni 1977 aufgenommen wurden.

Das Durchschnittsalter dieser Patientengruppe betrug 54.6 Jahre; das Durchschnittsalter der männlichen Patienten war 46.9 Jahre, das der weiblichen Patienten 62.4 Jahre. Das VerhätInis von Männern zu Frauen betrug etwa $2: 1$, was mit dem heutigen Verhältnis in der westlichen Welt übereinstimmt. 
Die Aufnahme fand ohne Auswahl seitens des R.C.H. statt, es sei denn, es lag Unzurechnungsfähigkeit vor, bevor die Krankheit, die die Amputation notwendig machte, erkannt wurde. Wenn man davon ausgeht, dass die Rehabilitation ein Lernprozess ist, so ist sie für einen dementen Patienten eine zu schwere Aufgabe. Mit Ausnahme von dieser absoluten Kontraindikation geht das Amputationsteam des R.C.H. von der Premisse aus, dass jedem rehabilitationsbedürftigen Patienten die Möglichkeit gegeben werden muss, selbst am Leibe zu erfahren, ob Rehabilitation zwecks Erreichung eines höheren funktionellen Niveaus möglich ist oder nicht. Treten während der Rehabilitation mögliche Kontraindikationen zutage, wird das vollständige Team sie beurteilen. Der Arzt, der Amputierten behandelt, ist nich fähig, allein zu beurteilen, ob Kontraindikationen auf einem Gebiet bestehen können, auf dem seine spezifischen Kentnisse unzulänglich sind.

Bevor die Aufnahme im R.C.H. stattfand, gab es nie einen direkten Kontakt mit dem Patienten, es sei denn, es wurde 'immediate fitting" angewandt.

Verschiedene Aspekte der Rehabilitation bei Beinamputierten werden näher beleuchtet, wie die Indikation zur Amputation, die Prothesewahl, die Aufnahmedauer u.s.w. Zum Schluss erfolgen die Ergebnisse, die die Leistungsfähigkeit des Protheseträgers sowie seine Unterbringung nach Entlassung aus dem R.C.H. betreffen.

Ausführlich wird die Aufgabe der sozialen Fürsorge, des psychologischen Dienstes und der Ergotherapie erläutert, wobei deutlich hervortritt, wie sehr sich die genannten Disziplinen tangieren.

Gesondert wurde eine Gruppe von 100 Patienten untersucht, die wegen vaskularischer Insuffizienz amputiert wurden, mit der Zielsetzung, die Leistungsfähigkeit mit der Prothese und die Unterbringung nach der Entlassung zu verdeutlichen.

Schlliesslich wurde für die gesamte Gruppe von 125 Patienten im März April 1978 eine Untersuchung in bezug auf die Leistungsfähigkeit als Protheseträger zu jenem Zeitpunkt durchgeführt.

20 Personen, die an der Untersuchung in den Jahren 1972 - 1977 beteiligt waren, waren inzwischen gestorben. Beiden übrigen 105 ehemaligen Rehabilitanden wurde festgestellt, das $84.7 \%$ noch immer in die Vaucher - Kategorie 3 bis einschliesslich 6 eingestuft werden konnten.

Wenn man berücksichtigt, dass $80 \%$ der Rehabilitanden über 50 Jahre und mehr als $31 \%$ über 70 Jahre waren, ist es einleuchtend, dass die Rehabilitation von Amputierten eine sinnvolle Sache sein kann. Eine durchaus berechtigte Forderung scheint deshalb zu sein, dass die Rehabilitation von Amputierten, namentlich auch von älteren Personen über 65 Jahre, ein Prozess ist, der von einem derartig spezialisierten Team, bestehend aus Fachärzten, Psychologen, Paramedizinern und Technikern, begleitet werden muss und dass dies in verantwortlicher Weise nur möglich ist, wenn die Amputierten in einem hierauf eingerichteten Rehabilitationszentrum zusammengebracht werden. Protheseversorgung und weitere Rehabilitation kann nicht in ausreichender Weise in den Pflegeheimen erfolgen, wo Kenntnisse, Fachkräfte und Ausrüstung fehlen.

Eine optimale Rehabilitation des Mensch-Maschine-Umwelt-Systems innerhalb der Struktur der Lucasstichting ist jedoch nur möglich, wenn die 
Rehabilitation nicht als ein isoliertes Geschehen in einem Rehabilitationszentrum betrachtet wird. Es hat sich herausgestellit, dass Kontakte mit der ersten und zweiten Stufe der Gesundheitsfürsorge unentbehrlich sind. Die Rehabilitation eines Amputierten muss bereits beginnen, bevor die Amputation erfolgt ist. Der Chirurg ist das erste Glied in der gesamten Rehabilitationskette. Zusammen mit dem Rehabilitationsarzt im Krankenhaus muss er die Heilkunde bei Patienten, die amputiert werden, ausüben, auch wenn Heilung nicht mehr möglich ist. Eine Amputation is zwar ein destruktiver Eingriff; sie kann für den Patienten sogar katastrophal werden, wenn der Chirurg die Amputation nur als das tragische Ende einer chirurgisch verlorenen Sache betrachtet, und wenn für ihn noch die Parole "haut et tôt" gilt!

Auch in Hinblik auf die erste Stufe (der Rehabilitation) und namentlich in Hinblick auf die sg. Kreuzvereine hat dass Blatt sich innerhalb des Rahmens der Amputiertenfürsorge durch die Gemeindeschwestern gewendet.

In der Provinz Limburg scheint die Wache abgelöst und damit die Parole verändert worden zu sein. Abgesehen von der grundlegenden Veränderung von der "haut et tôt"-Amputation auf Oberschenkelniveau zur Unterbeinamputation mit dem alleinigen Ziel "preservation of the knee joint" (the current problem of the geriatric amputee), gibt es auch andere wichtige Amputationsniveaus, die im Gegensatz zum Ausland in unserem Land noch zu wenig Beachtung finden. In den Kapiteln VI und VII wurden deshalb die SymeExartikulation und die Exartikulation durch das Kniegelenk behandelt und zwar nicht nur, weil sie ein mögliches Amputationsniveau für ältere Personen sind, sondern auch, weil sie bei Anwendung bei Adoleszenten und Erwachsenen wichtige Vorteile haben.

Die Folgen einer sich ändernden Bevölkerungsstruktur mit der sich daraus ergebenden Problematik für Amputierte wurde in Kapitel VIII beschrieben. Eine regionale Lösung dieser Probleme erscheint ratsam, da ein grosses soziales Problem zu entstehen droht. Eine regionale Inangriffnahme dieser Probleme ist möglich, wenn Krankenhausverwaltungen, Direktionen und Stäbe medizinischer Mitarbeiter ihre volle Mitarbeit an der Verwirklichung zusagen wollen. Dafür ist erforderlich, dass ein Rehabilitationsarzt in jedem Krankenhaus dem medizinischen Stab angehört. Die Rolle dieses Rehabilitationsarztes und die Abgrenzung der gegenseitigen Aufgabenbereiche innerhalb des medizinischer Stabes in bezug auf die rehalibitationsbedürftigen Patienten im allgemeinen müssen festgelegt werden. Dies gilt ebenso für Formen von Zusammenarbeit mit regionalen Rehabilitationszentren.

Die Probleme, mit denen der Amputierte konfrontiert wird, und die sich daraus ergebenden Folgen für die niederländische Gesundheitsfürsorge fordern eine Veränderung im therapeutischen Handeln bei einer nicht zu verhindernden Prozentsatzverschiebung des Altersgefüges in userem Land.

Dass "Hoensbroeck" im Dienste der limburgischen Gesundheitsfürsorge bereits eine "starke Huisinghe" wäre - siehe Kapitel I - wäre sicherlich eine voreilige Feststellung und würde nur von Selbstüberschätzung zeugen. Der Wille und die Tatkraft, solches in Zukunft zu verwirklichen, sind jedoch ganz bestimmt vorhanden. 


\section{Epiloque}

L'histoire par rapport à l'amputation des extrémités inférieures montre comment, à travers les siècles d'autres aspects eurent toujours l'attention, dépendant de notions nouvellement acquises ou d'autres objectifs. L'amputation, visée au début à sauver la vie, se trouvait être une procédure létale par suite d'infection ou d"expiration par perte de sang. Ignorant l'existence des micro-organismes, la viltesse avec laquelle une amputation eut lieu, fut déterminant pour un succès éventuel. Paré et Larrey sont des exposants de cette époque.

Au $19 \mathrm{e}$ siècle on dominait mieux l'hémostase; l'asepsie et l'anti-asepsie devinrent peu à peu le terrain de méthode d"investigation mondiale. De plus en plus le chirurgien connut la méthode aseptique. L'anesthésie moderne, née dans le même siècle, rendit l'operation immédiate moins nécessaire. Par ceci il y eut la possibilité de développer des techniques opératoires avec plus d'attention pour la surveillance de tissu vital. On peut dire que Lister et Syme ont été les pionniers de cette manière d'approche complètement différente.

C'est possible qu'au cercle médical, la naissance des prothèses articulées, qui était sans aucun doute plus importante, fut peu remarquée. C'est Ambroise Paré qui y a beaucoup contribué. Des techniques prothétiques améloirées ont peu à peu mis en avant la combinaison de moignon-prothèse comme entité fonctionelle. L'attention pour les niveaux d'amputation et pour les techniques des amputations y est très minitieusement liée.

La rupture d'une vieille trame n'était pas toujours simple. Une illustration pour ceci est l'ordre donné à l'armée pour le Service Médical allemand pendant la deuxième geurre mondiale, qui, sur les instances de Kirschner, devait annuler l'application sans motif des schémas de Zur Verth c.s.

Seulement l,"'emergency case" oblige le chirurgien d'opérer "An der Stelle der Not" "quand d'autres mesures opératoires n'offrent plus de soulagement. Alors l'opération "An der Stelle der Wahl" n'est pas indiquée, parce qu'une technique d'amputation correcte, avec une longue durée de narcose qui est nécessaire, peut contribuer à une fin défavorable.

A juste titre on peut remarquer, que ces expressions, qui sont nées dans des circonstances guerrières, passent aussi pour l'individu en développement. Aussi le chirurgien, qui manie le principe de l' "An der Stelle der Not" peut être assuré de l'appréciation de l'équipe d'amputation et de la reconnaissance du malade. Le chirurgien qui fait cela, fait preuve d'avoir conscience de sa grande responsabilité, comme premier homme dans le procès de réadaptation.

Dans les années soixante les chirurgiens comme Berlemont, Burgess, Murdoch, Marquardt, Jansen, Vitalie et Dederich ont provoqué une révolution dans les techniques d'amputation et dans la prothésiologie. Les problèmes du lévier étaient évincés par la physiologie du système circulaire du moignon, anticipant sur le fonctionnement à attendre du système homme-machine.

Dans le Monde Occidental $80 \%$ environ des amputations actuelles ont lieu à cause d'une maladie dégénérative, dont la plupart des victimes sont des personnes âgées. Alors l'idée se manifeste pourquoi dans ces études l'élément de l'environnement fut ajouté au système homme-machine. L'estimation et le respect pour la personne âgée, déterminés dans la Charité latine se battent 
alors pour la priorité, où en même temps des motifs économiques, l'hygiène motivée ou une meilleure efficacité des mesures à poursuivie dans l'hygiène, ont part à cette compétition.

Dans ce système de l'homme-sa machine-son environmement; il parait que chaque personne amputẻe, dépendant de son âge, est confrontée par des problèmes spéciaux.

La réadaptation des personnes amputées n'est pas seulement une question de technique prothétique. La réadaptation d'une personne amputée repose sur les trois piliers nommés ci-dessus, qui doivent être réglés les uns sur les autres, et qu"on ne peut pas voir chacun sur soi. On peut réaliser cela dans une approche multidisciplinaire, où il $\mathrm{y}$ a des fréquents contacts intensifs interdisciplinaires. Ces dernières années le R.T.H., séparé de l'équipe d'amputation R.C.H. quant à l'administration et l'organisation, mais travaillant d'une manière très intime avec cette équipe, au profit du système de l'homme-machine-environnement, a été réalisé. Les techniciens du R.T.H., avec à la tête un ingénieur mécanicien, mettent en service de la médicine de réadaptation leur science et savoir en matière de problèmes techniques et mécaniques, des matériaux de l'esthétique industrielle, de l'électronique et de la technique d'ordinateur. Le technicien, si l'on vent l'ingénieur médical a le 'know-how'" par rapport à la fabrication des moyens et des adaptations pour les handicapés. Il a des relations intimes avec des facultés techniques. C'est ainsi qu'il peut, en travaillant dans la Fondation pour Réadaptation Lucas, répondre aux problèmes auxquels l'équipe d'amputation du R.C.H. se heurte, en réalisant des adaptations individuelles ou bien de l'environnement. Après la réalisation des moyens, l'évaluation par l'équipe d'amputation peut avoir lieu. Cette approche liée à l'équipe, par laquelle le technicien est "alimenté" en donnés de la clinique et du milieu de l'amputé, ne peut qu'être utile aux malades hospitalisés au centre de réadaptation.

Il en est de même pour les centres comme le A.C.H. ou le L.C.H., le V.I.A. ou le C.B.H., ce dernier, qui est le plus jeune rejeton de la Fondation Lucas (au moins pour le moment) prouvera encore son utilité.

Dans cette étude on a rendu ses comptes concernant le traitement de 125 malades qui comme suite de l'amputation d'une ou des deux extrémités inférieures ont été hospitalisés pour réadaptation dans le centre de réadaptation "Hoensbroeck" dans la période de juin 1972 - juin 1977.

L'âge moyen de ce groupe de malades était de 54.6 ans, l'âge moyen des malades masculins était de 46.9 ans, celui des malades féminines était de 62.4 ans. La proportion entre les hommes et les femmes était de $2: \mathbb{1}$, ce qui correspond à la proportion qui existe à ce moment dans le Monde Occidental.

L'hospitalisation eut lieu sans sélection du côté du R.C.H., sauf en cas de démenti qui existait déjà awant que la maladie, qui portait à l'amputation, fut manifeste. Si la réadaptation est un procès d'apprentissage, ceci est un exercie trop lourd pour un malade dément. Sans parler de cette contre-indication absolute, l'équipe d'amputation du R.C.H. sort de la prémisse que chaque malade à réadapter doit avoir l'occasion après l'amputation, d'éprouver à son propre corps, si la réadaptation laquelle tend à un niveau fonctionnel plus élevé, est oui ou non possible. Quand pendant la réadaptation des contre-indications possibles se rélèvent, toute l'équipe les critiquera. Le médecin qui 
träte des personnes amputées, n'est pas capable à lui seul de juger des contre-indications qui se présentent dans un domaine ou sa compétence spécifique fait défaut.

Avant que l'hospitalisation dans le R.C.H. eût lieu, il n"y avait jamais de contact direct awec le malade, sauf dans les cas où l'on mit l'." "immediate fitting " en application.

Des diverses facettes de la réadaptation auprès des personnes qui ont une amputation d'une jambe sont précisées, comme l'indiation à l'amputation, le choix de la prothèse, la durée de l'hospitalisation etc. qui débouchent dans des rêsultats par rapport au fonctionnement, comme porteur d'une prothèse, ainsi que le logement après la démission du R.C.H.

On est entré dans le détail quant à la tẩche du travail social, le service psychologique et l'ergothérapie; il devient évident quels sont les points de contact entre les disciplines nommées ci-dessus.

A cause d'insuffisance vasculaire, un groupe de 100 personnes amputées fut précisé, avec comme objectif le fonctionnement avec la prothèse et le logement après la démission.

Enfin on fit une investigation pout tout le groupe de 125 malades en mars avril 1978 en rapport avec le fonctionnement comme porteur de prothèse à ce moment-là:

Vingt personnes, dont il s'agissait auprès de la recherche faite dans les années 1972 - 1977, étaitent décedées sur ces entrefaites. Des 105 personnes ex-réadaptés on put constater que $84.7 \%$ pouvait toujours être classé dans la catégorie de Vaucher 3 jusqu'à 6 inclusivement.

Eu égard au fait que $80 \%$ des réadaptés était plus âgé que 50 ans et plus de $31 \%$ était plus âgé que 70 ans, il peut être clair que la réadaptation des personnes amputées peut être un objet significatif. La conclusion paraît justifée que la réadaptation de personnes amputées, notamment des âgés aussi de plus de 65 ans est un procès, qui doit être accompagné par une équipe de médecins compétents par des paramédecins et des techniciens tellement spécialisés, que ceci peut seulement être réalisé par la concentration de ces personnes amputées dans un centre de réadaptation équipé pour cela. L'approvisionnement en prothèses et une réadaptation supplémentaire ne peut pas se passer d'une manière motivée dans les établissements hospitaliers, qui manquent de savoir, de force physique spécialisée et d'équipement.

La réadaptation optimale du système homme-machine-environnement dans la structure de la Fondation Lucas est seulement possible, quand la réadaptation n'est pas seulement vue comme un fait isolé dans un centre de réadaptation. Des contacts avec le premier et le deuxième échelon de l'hygiène ont semblé être indispensables. La réadaptation d'une personne amputée doit commencer avant que l'amputation soit un fait. Le chirurgien est le premier maillon de la chaîne de réadaptation. En commun avec le médecin de réadaptation dans l'hôpital, il doit exercer la chirurgie auprès des malades à amputer, aussi quand la guérison n'est plus possible. Il est vrai qu'une amputation est une intervention destructive, mais elle peut devenir vraiment désastreuse pour le malade quand le chirurgien voit l'amputation seulement comme une fin tragique d'une affaire chirurgicale infaisable et qu'il écoute encore le mot d'ordre "'haut et tôt". 
A l'égard aussi du premier échelon et des associations comme la Croix Verte, etc. les choses ont changé de face dans le cadre des soins de l'infirmière de l'assistance médicale à domicile pour la personne amputée.

Au Limbourg on a relevé la garde et par cela le mot d'ordre a changé. A côté du changement de l'amputation "haut et tôt'" au niveau de la cuisse, à l'amputation de la jambe inferieure avec comme seul but "preservation of the knee joint" (the current problem of the geriatric amputee) il y a aussi d'autres niveaux d'amputation importants qui par opposition à l'étranger sont encore trop peu appréciés. C'était pourquoi les chapitres VI et VII traitaient l'articulation Syme et l'ex-articulation du genou, pas seulement comme niveau d'amputation possible auprès des personnes âgées, mais en même temps avec des avantages importants, si on l'applique auprès des adolescents et des adultes.

Les conséquences de la structure de la population changée étaient décrites dans le chapitre VIII. Maintenant qu'un grand problème social se prépare, il semble nécessaire de tenir tête à ces problèmes par région. La régionalisation peut se mettre en train quand les directions des hôpitaux, les directions et les cadres mëdicaux veulent contribuer intégralement à la réalisation. Pour cela il est nécessaire que dans chaque hôpital un médecin de réadaptation fasse partie des cadres médicaux. Il faut que le rôle de ce médecin de réadaptation et la répartition mutuelle des tâches dans les cadres médicaux par rapport aux malades à réadapter en général, soit fixé. Il en est de même pour les procédures de collaboration avec les centres régionaux de réadaptation.

Les problèmes avec lesquels la personne amputée est confrontée et les conséquences pour l'Hygiène néerlandaise qui en résultent, exigent une transformation dans le traitement thérapeutique, avec un décalage dans les pourcentages des groupes d'âge qui n'est pas à empêcher.

Ce seraient des paroles prématurées de dire qu" "Hoensbroeck" aux service de l'Hygiène limbourgeoise serait dêjà une "sterke Huisinghe", on y avait préludé dans le chapitre I et cela ne ferait que preuve de présomption. La volonté et l'énergie pour la réalisation à l'avenir sont bien présents. 



\section{Samenvatting.}

Het doel van deze studie was te onderzoeken of de resultaten, behaald door de revalidatie van beengeamputeerden, in een organisatiestructuur zoals deze aanwezig is binnen de Lucasstichting voor Revalidatie, beantwoorden aan de definitie van het begrip revalidatie, gegeven door de W.H.O. in 1968.

De W.H.O. streeft in haar definitie van het begrip revalidatie naar "the highest possible level of functional ability".

Om dit streven zo goed mogelijk gestalte te geven moet worden voldaan aan enkele voorwaarden. Deze worden in de hoofdstukken I $t / \mathrm{m} \mathrm{IV}$ omschreven.

Hoofdstuk I geeft een beschrijving van de centra, gesitueerd binnen de structuur van de Lucasstichting als setting waarin deze evaluatieve studie plaats vond. Deze beschrijving brengt ook centra voor het voetlicht, welke in eerste instantie weinig te maken lijken te hebben met de revalidatie van beengeamputeerden. Bij nadere beschouwing blijkt echter dat de Lucasstichting streeft naar een coördinatie en concentratie van deskundigheid en voorzieningen, waarop regelmatig een beroep kan worden gedaan, indien de noodzaak hiertoe zich voordoet tijdens het revalidatieproces.

Hoofdstuk II stelt als een schril contrast tegenover elkaar de behandeling van geamputeerden in vroeger eeuwen en optimale revalidatiemogelijkheden, zoals gegeven binnen een modern revalidatiecentrum.

Optimale revalidatie van beengeamputeerden wordt beschreven als die revalidatie, die de geamputeerde de geborgenheid biedt van een team van deskundigen en disciplines op medisch, psychologisch, paramedisch en sociaal terrein. Voor deze interdisciplinaire organisatie, in dit amputatieteam, is geen duidelijke hierarchie in het algemeen aan te geven. De te volgen gedragslijn in het revalidatieproces dient gestuurd te worden door die discipline, welke het beste in kan spelen op de behoefte van de revalidant op dat moment, zodat de vorderingen van diens revalidatieproces niet belemmerd worden.

Een revalidatieproces is echter geen geïsoleerd gebeuren in een revalidatie centrum, dat pas aanvangt wanneer een revalidant voor dit doel wordt "aangeboden " door een ander, eerstbehandelend echelon in de gezondheidszorg of eindigt wanneer een revalidatieproces zijn beslag heeft gevonden.

Daarom werd in hoofstuk III uitgebreid ingegaan op de voor- en nazorg. Intensieve contacten met extramurale werkers, voor en na het revalidatieproces, blijken een onmisbare voorwaarde. De begeleiding van de mens die een mutilerende ingreep moet ondergaan dient te beginnen voor de amputatie een feit is, hetgeen betekent dat ook de chirurg en revalidatie-arts in het ziekenhuis deel uitmaken van de revalidatieketen. Na beëindigen van het revalidatieproces vormen de wijkverplegenden de schakel naar het weer funktioneren in de samenleving.

Op de laatste voorwaarde, maar in prioriteit zeker op de eerste plaats, wordt ingegaan in hoofdstuk IV, dat het "mens-machine-milieu systeem" tot onderwerp heeft. 
De revalidatie van een geamputeerde is te vergelijken met het ontwikkelen en goed laten functioneren van een mens-machine systeem. Dit mens-machine systeem, dit mens-prothese systeem moet teruggeplaatst worden in het mensmilieu systeem, dat al of niet rekening houdt met de machinefactor, de prothese. Het systeem mens-milieu is in voortdurende interactie. Binnen bepaalde grenzen kan de mens zich handhaven en functioneren in zijn milieu. Het systeem mens-milieu be reikt echter een kritische grens, wanneer bepaalde fysiologische grenzen worden overschreden. Deze grens wordt overschreden door een vergaande mutilatie waartoe amputatie van een extremiteit zeker gerekend moet worden. Door een amputatie wordt het somatische, psychische en sociale functioneren op elke leeftijd verstoord. Dit mens-machine-milieu systeem wordt dan in hoofstuk IV gedifferentieerd naar drie categoriën, elk met hun eigen specifieke problemen: bejaarden, volwassenen, kinderen en adolescenten.

Nadat deze basisprincipes, welke kunnen voeren tot een zo goed mogelijke revalidatie van beengeamputeerden zijn omschreven, worden deze in hoofdstuk $\mathrm{V}$ getoetst aan de revalidatie van 125 patiënten, opgenomen tussen juni 1972 - juni 1977.

De gemiddelde leeftijd van deze groep patiënten was 54.6 jaar. De gemiddelde leeftijd van de mannelijke patiënten was 46.9 jaar, van de vrouwelijke patiënten was deze 62.4 jaar. De verhouding tussen mannen en vrouwen was ongeveer $2: 1$.

De opname vond plaats zonder selectie van de kant van het revalidatie centrum, behalve wanneer er sprake was van dementie, welke reeds bestond voordat de ziekte, welke tot amputatie voerde, manifest werd. Contact met de patiënt vòòr opname in het revalidatie centrum plaats vond, bestond alleen in die gevallen waarbij immediate fittig werd toegepast.

Diverse facetten van de revalidatie bij beengeamputeerden worden nader toegelicht, zoals indicatie tot amputatie, prothesekeuze, opnameduur etc., uitmondend in resultaten met betrekking tot het functioneren als prothesedrager alsmede de huisvesting na ontslag uit het revalidatiecentrum.

Op de taak van de psycholoog, de maatschappelijk werkende en de ergotherapeut wordt uitgebreid ingegaan, waarbij hun functie in het revalidatieproces van beengeamputeerden wordt aangeduid.

Afzonderlijk werd de groep van 100, op grond van vasculaire insufficiëntie, geamputeerden belicht met als doelstelling hun functioneren met de prothese en de huisvesting na ontslag. Tenslotte werd voor de gehele groep van 125 patiënten een onderzoek verricht in maart/april 1978 met betrekking tot het functioneren als prothesedrager. Van de op dat moment nog resterende 105 ex-revalidanten werd vastgesteld dat $84.7 \%$ nog steeds goed functioneerden. De conclusie lijkt gerechtvaardigd dat revalidatie van geamputeerden, met name ook van ouderen boven 65 jaar, een proces is dat moet worden begeleid door een zodanig gespecialiseerd team van deskundige artsen, psychologen, paramedici en technici dat dit alleen verantwoord kan gebeuren door een concentratie van deze geamputeerden in een daarop ingesteld revalidatie centrum.

Hoofdstuk VI en VII gaan in op de problematiek rond de amputatie in voeten voetwortel en de knie-exarticulatie. De Syme-exarticulatie is nog steeds een 
goed amputatieniveau, hetgeen eveneens geldt voor de knie-exarticulatie. Beargumenteerd wordt dat deze 2 amputatieniveau's in Nederland niet de aandacht gekregen hebben die ze verdienen, gezien de resultaten hiermede behaald in andere landen van de westerse wereld. Beide amputatieniveau's zijn niet alleen van belang bij bejaarden, maar bieden tevens belangrijke voordelen, indien toegepast bij adolescenten en volwassenen.

Hoofdstuk VIII gaat in op de te verwachten veranderende bevolkingsopbouw in Nederland met de daaruit voortvloeiende problematiek voor geamputeerden. Met name wordt gewezen op het feit dat de stijging van het aantal amputaties bij bejaarden groter is dan op grond van de vergrijzing van deze bevolkingsgroep verwacht mag worden.

Aangezien rond $80 \%$ van de amputaties in West-Europa verricht wordt bij bejaarden, wacht onze samenleving een groot probleem, tenzij er een verandering komt in therapeutisch handelen, bij een niet te voorkomen verschuiving in de percentages van de leeftijdsgroepen in ons land. 
$\therefore: \quad:$ 


\section{SUMMARY}

This study was made to examine whether the results obtained with the rehabilitation of leg amputees - within an organization structure such as existing in the Lucas Institute - approach the conception of rehabilitation as given by the W.H.O. in 1968 .

In its definition of rehabilitation the W.H.O. reaches to "the highest possible level of functional ability".

To create an optimal situation in which this aim can be realized, certain conditions must be fulfilled. These conditions have been elaborated in chapters I to IV.

Chapter I gives a description of the centres which operate within the organization structure of the Lucas Institute, in the setting of which this evaluation study could take place. The description also comprises centres which, at first view, seem to bear little relation to the rehabilitation of a leg amputee. At closer view however it becomes clear that the Lucas Institute aims at coordinating and concentrating all those skills and facilities to which, in the course of the rehabilitation process, an appeal may have to be made at one moment or another.

Chapter II portrays the violent contrast between the treatment of amputees in earlier ages and the optimal facilities as presently available in a modern rehabilitation hospital.

Optimal rehabilitation of leg amputees is described as the rehabilitation which offers the amputee the security and protection of an expert team in which the medical, psychological, paramedical and social disciplines are represented. In general, such an interdisciplinary team will not work along hierarchic principles. The line of conduct to be followed at a certain stage of the rehabilitation process can best be set out by the one discipline which is best able to act on the need of the patient in that stage, so that the healing process of the patient may follow its course with least hindrance.

Rehabilitation however is no isolated effort taking place in a rehabilitation hospital. It does not start only at the moment that the patient is proposed for admission by a foregoing echelon in health care. Nor does it terminate when the treatment in the hospital is concluded.

Chapter III therefore deals extensively with the subjects of pre-care and after-care. Intensive contacts with extramural health care workers, before and after the actual rehabilitation process, have proved to be indispensable. The preparation of the individual who has to undergo a mutilating operation should start before the operation actually takes place, which means that the surgeon and the treating physician in the hospital are a part of the rehabilitation chain from the start. At the end of the actual rehabilitation process, it is the district nurse who forms the link between the patient and his functioning again in his community.

Chapter IV deals with the last-named condition, which in the order of priorities however certainly ranks first. The subject of this chapter is the "man-machine-milieu" system.

The rehabilitation of the amputee can be compared to the process of develo- 
ping and implementing a man-machine system. This man-machine system, this man-artificial limb system, must be relocated in the man-milieu system, which may or may not accept the machine factor. The man-milieu system is continuously subject to interactive influences. Within certain boundaries the individual is able to live and function in his milieu. A critical border is reached however when certain psychological limits are broken. A severe mutilation, such as the amputation of an extremity, is such a limit. The somatic, psychic and social functioning of the individual will be disturbed by an amputation, irrespective of age group. Furthermore, this man-machine-milieu system is differentiated in chapter IV into three categories, each with its own particular problems: the elderly, adults, children and adolescents.

Chapter V describes an evaluation process which was carried out to check rehabilitation results. The evaluation concerned a group of 125 amputees who had been patients of the Lucas Institute in the years between June 1972 and June 1977.

The average age of this group of patients was 54.6 years; for male patients this was 46.9 years, for woman patients 62.4 years. The ratio men - women was circa 2:1.

For admission of these patients no selection had taken place on the part of the Institute, except in cases of dementia which already existed before the disease leading to the amputation became manifest. Direct contact with a patient before his admission to the hospital had taken place only in those cases where immediate fitting was applied.

The chapter also deals with various facets of the rehabilitation of leg amputees, such as indication for surgery, choice of medical aid, length of hospitalization, and, finally, the functional ability of the aid users and their housing situation.

The chapter further elaborates on the tasks of the psychologist, the social worker and the ergo-therapeutic specialist and outlines their specific functions in the rehabilitation process of leg amputees.

Of the group of 125 studied, 100 had undergone amputation on the grounds of vascular deficiency. A special survey was made of these patients with focus on their functional ability after dismissal from the hospital and also on their housing situation.

Finally, in March/April 1978, a survey was carried out which covered the entire group of 125 patients and here again the functional ability with the artificial limb was the main subject. It was found that for $84.7 \%$ of the 105 ex-patients remaining at that moment the functional ability had remained satisfactory.

From the results of the survey it may justifiably be concluded that the rehabilitation of amputees, in particular of elderly people above 65 years of age, is a process which requires the attendance of a highly skilled team of physicians, psychologists, paramedical staff and technical staff. Such services can reasonably only be offered to groups of amputees centralized in a rehabilitation hospital.

Chapters VI and VII deal with the specific problems of foot and foot-tarsus amputation and of knee-exarticulation. The Syme exarticulation is still today an acceptable amputation level. This is also true of the knee-exarticulation. It 
is argued that the two last-named amputation levels do not receive in The Netherlands the attention which they deserve, which is all the more objectionable if one considers the positive results obtained in other countries of Western Europe. Both levels are of importance, not only for the elderly. They also hold considerable advantages for treatment of adolescents and adults.

Chapter VIII enlarges upon expectations which may be derived from the changing population structure in The Netherlands and on the implications as regards amputees. Strong emphasis is placed on the fact that already now the number of amputations in the most advanced age group is growing faster than the ageing of this population group would lead to expect.

Lastly, if one takes full account of the fact that around $80 \%$ of all amputations in Western Europe are carried out among the elderly, it cannot be ignored that a vast problem awaits our society, unless a new awareness brings about a fundamental change in therapeutic thinking and acting and heed is taken of the undeniable shifting of age groups in the population structure of our country. 


\section{REFERENTIES}

Arnold W:

Congental abscence of the fibula

Clinical Orthopatedics. 14. page 20-29. (1959).

Awater H.

Hoofd Orthopedische Instrumentmakerij R.T.H.

Pers. Mededeling.

Bakker H:

Onderzoek naar amputaties en prothesevoorziening in Nederland in 1969.

T. soc. Geneesk. 51. pag, 557-560. (1973).

Bär C.:

Amputaties en Prothesen.

Ned. T. Geneesk. 101. pag. 1725-1732. (1957).

Bar A., Seliktar R., Suzack Z:

Pneumatic supracondylar suspension for knee-disarticulation prostheses.

Orthotics and Prosthetics. Vol. 31. pag. 3-7. (1977).

Baudens J:

Nouvelle methode des amputations.

G. Bailliere Ed. Paris. (1842).

Baumann J., Ruepp R.:

Die Biomechanik der Beinprothesenversorgung im Alter.

Der Orthopäde. 7. pag. 106-109. (1978).

Baumgartner R.:

Amputation und Prothesenversorgung beim Kind.

Ferdinand Enke Verlag. Stuttgart. Bücherei des Orthopäden. 16. (1977).

Baumgartner $\mathbf{R}$ :

Allgemeine Probleme der Indikation und der operativen Technik der Amputation und Prothesenversorgung.

Der Orthopäde. pag. 94-98. (1978).

Bejaardenonderzoek Beek-Swalmen. Rijksuniversiteit Limburg 1977.

Berlemont M. , Weber R:

Appareillage provisoire des amputés du membre inferieur sur la table d'operations.

Acta Orthop. Belg. 32, pag. 662. (1966).

Bremer J.:

De ziekenhuispatiënt.

Dekker\& van de Vegt. Nijmegen. (1972).

Breslau W. J.:

Grote Amputaties en Revalidatie. Mededeling no. 5.

Uitgave van de Medische Dienst van de Soc. Verz. Bank. (1956).

Broca A., Ducroquet C.:

Ardificial Limbs. Military Medical Manuals. English ed.

Sir Alfred Keogh and R. C. Elnslie eds. pag. 77-78. (1918).

Burgess E. Romano R., Zettl J., Schrock R.:

Amputation of the leg for Peripheral Vascular Insufficiency.

J. Bone and Joint Surg. Vol. 53A. pag. 874-889. (1971).

Burgess E.: Amputation in vascular disorders.

1. Internationaler Kongress für Prothesentechnik und funktionelle Rehabilitation.

Wien, Österreich. Vol. 1. pag. 29-41. (1973).

Buytendijk F.:

Algemene theorie der menselijke houding en beweging.

C.B.S.:

Het Spectrum N.V. Utrecht/Antwerpen. (1964).

De toekomstige demografische ontwikkeling in Nederland na 1975.

"s-Gravenhage, Staatsuitgeverij. (1976).

Chi-Tsou Huang, Jackson J., Moore N., Fine Ph., Keith V., Kuhlemeier Phd., Traugh G., Saunders P.:

Amputation: Energy Cost of Ambulation.

Arch. Phys. Medical Rehrabil. Vol. 60. pag. 18-24. (1979). 
Commissie van de Europese Gemeenschappen:

Arbeidstraumatologie. Uitgangspunt van de Revalidatie bij de slachtoffers van ongevallen.

Luxemburg. (1973).

Davidson $\mathrm{H}$ : :

The Syme amputation in Children:

I. Bone and Joint Surg. Vol. 57A. pag. 905-909. (1975).

Dederich R.:

Amputationen der unteren Extremität.

G. Thieme Verllag. Stuttgart. (1970).

Dederich R.:

Die Muskelplastischen Stumfkorrekturen bei Amputationen der oberen und unteren

Extremitaten einschliesslich der prothetischen Sofortversorgung.

1. Internationaler Kongress für Prothesentechnik und funktionelle Rehabilitation.

Wien, Öterreich. Vol. 1. pag. 13-22. (1973).

Elmslie R:

Modern operative surgery, Carson.

Cassel \& Co. London. Vol. 1. pag. 132. (1924).

Festen H.:

Organisatie van de gezondheidszorgen invaliditeit.

T. soc. Geneesk. 48. pag. 117-125. (1970).

Festen H.:

Onze gezondheidszorg op het , werkeerde pad".

Metamedica 56. pag. 110-114. (1977).

Friedmann L. W.:

Amputation, Rehabilitation, and Civilization.

1. Internationaler Kongress für Prothesentechnik und funktionelleRehabilitation.

Wien, Österreich. Vol. 1. pag. 5-9. (1973).

Gerendas O.:

Models of Prosthetic Clinic Team Management.

Intercl. Inf. Bull. 12. pag. 1-5. (1973)..

Gillis L.:

Amputations.

William Heinemann Medical Books L. T. D. London. (1954).

Golldberg B., Baker G.:

A review of the Syme amputation.

1. Internationaler Kongress für Prothesentechnik und funktionelle Rehabilitation.

Wien, Osterreich. Vol. I. pag. 169-173. (1973).

Gyon F.:

Gazette des hospiteaux. pag. 514. (1868).

Harding $\mathrm{H}$.:

Knee Disarticulation and Syme's Amputation.

The yearbook of Orthopedics and Traumatic Surgery. pag. 311-312. (1969).

Harris R:

The History and Development of Syme's Amputation.

Selected Articles from Artificial Limbs.

Robert Krieger Publishing Co inc. Huntington. N.Y. (1970).

Harris R.:

Syme's Amputation. The technical details for success.

J. Bione and Joint Surg. Vol. 38B. pag. 614-632. (1956).

Hattinga - Verschure $J_{\text {.: }}$ :

Zelfzorg en mantelzorg voor gezondheid.

Metamedica 55. pag. 105-109. (1977).

w. d. Heul R.:

Biopsie van beentumoren.

Ned. T. Geneesk. 112. pag. 935-938. (1968).

Holzhauer $F_{* m} \vee$. Minden $J$.:

Psychologie. Theorie en Practijk.

Stenfert Kroese. Leiden. (1975). 
Hoogendoom D:

Enkele opmerkingen ower de betekenis van de veroudering van de bevolking voor de gezondheidszorg.

Ned. T. Geneesk 121 pag. 1639-1643. (1977).

Hoogendoorn D.:

Mededelingen Stichting Medische Registratie.

De invloed van de veroudering van de bevolking op de samenstelling van de klinisch behandelde patientenpopulatie, gerangschikt naar specialisme.

Ned. T. Geneesk. 123. pag. 141-144. (1979).

Homby R., Harris R.."

Syme's Amputation. Follow-up study of weight-bearing in sixty-eight Patients.

J. Bone and Joint Surg, Vol. 57A. pag. 346-349. (1975).

Huizinga J.:

Herfsttij der Middeleeuwen.

Tjeenk Willink \& Zn. Haarlem. (1957).

1.S.P.O.:

Constitution of the International Society for Prosthetics and Orthotics.

P.O. Box 42 DK. 2900 Hellerup, Denmark.

Jansen $\mathbb{K}$.:

Management of the Knee Disarticulation.

Prosthetics Iriternational. Copenhagen pag. 103-104. (1960).

Karthaus P.:

Amputatie van de onderste extremiteit. Diss. 1973.

Wolters - Noordhoff. Grafische Bedrijwen N.V. Groningen.

Kingma $\mathrm{M}$ :

Nederlands Leerboek der Orihopedie.

Bohn, Scheltema \& Holkema. (1977).

Kirk N.:

Amputations.

W. F. Prior Co, inc. Hagerstown. Maryland. (1942).

de Klerk J.:

Onderzoek naar speciale omscholingsfaciliteiten voor gehandicapten.

G.M.D. - R.I.M. Amsterdam. (1976).

Knoche W:

Knieexartikulations-Prothesen in Zukunft eine Standard-Versorgung?

Orthopädie Technik. 6. pag. 91-92. (1975).

Kortbeek L.:

Begeleiding.

Metamedica 55. pag. 238-240. (1976)

Kübler - Ross E:

Lessen voor levenden (gesprekken met stervenden).

Uitgeverij Ambo n.v. Bilthoven. (1971).

Langdale - Kelham R., Perkins G.:

Amputations and artificial limbs..

Oxford London. (1942).

Leering $\mathrm{C}$ : :

Het belang der zieken nog steeds de hoogste wet....?

Metamedica 55. pag. 197-202. (1976).

Lehman $\mathrm{H}$.:

Age and Achievement.

Princeton University Press. Princeton. (1953).

Loon H.:

Biological and Biomechanical Principles in Amputation Surgery.

Prosthetics International. Proceedings of the Second International Prosthetic Course.

Copenhagen. Denmark. pag. 41-58. (1960).

Marquardt E. Popplow K., Hillig A.:

Psychologische Probleme in Verbindung mit Amputationen.

Rehabilitation. 15, pag. 174-181, (1976). 
Marquardt E:

Pers. Mededeling.

Mazet R., Schiller F., Dunn O., Neufield A.:

Influence of prosthetic healing on the health of geriatric amputees.

Report of Project 431. Washington D.C. Office of Vocational Rehabilitation. (1959),

Mazet R., Hennesy C.

Knee Disarticulation. a New Technique and a New Knee-Joint Mechanism.

J. Bone and Joint Surg. Vol 48A. Pag. 126-139. (1966):

Mazet R., Schmitter E., Chupurdia R.:

Disarticulation of the Knee. a follow-up report.

J. Bone and Joint Jurg. Vol. 60A. pag. 675-678. (1978).

Mc.Kenzie D.:

Considerations on Amputations on the Child.

Prosthetics International. Copenhagen. pag. 119-120. (1960).

Mertens A.:

Nazorgdiensten.

T. soc. Geneesk. 51. pag. 541. (1973).

Molen N., Rozendal R., van Faassen $F_{\text {., }}$ Rijneveld $\mathrm{H}_{\text {: }}$ :

Problemen bij de beoordeling van de gang van onderbeenprothesediragers.

T. soc. Geneesk. 51. pag. 550-556. (1973).

de Moor R.:

Herfstij van de le vensloop. Beschouwingen over de ouderdom.

Het Spectrum. (1956).

Munnichs I.:

Herfsttij van de levensloop.

Het Spectrum. (1956).

Murdoch G.:

Amputation Surgery in the lower extremity. Pant 2.

Prosthetics and Orthotics International. Vol. I. pag. 183-192. (1977).

Murdoch G.:

Level of Amputations and Limiting Factors.

Ann. Roy. Coll. Surg 40. pag. 204-216. (1967).

Nachbaur E.:

Prothesenversorgung mit Oberschaft.

Orthopädie Technik. 3. pag. 29-30. (1976).

Neff G., Winkler $E_{\text {., Waigand }} \mathrm{H}_{\text {: }}$ :

Die modificierten Stumfformen nach Chopart, Pirogoff und Syme.

Orthopädie Technik. 1. pag. 1-4. (1977).

Newcombe J., Marcuson R:

Through-Knee Amputation.

Brit. J. Surg. 59. pag. 260-266. (1972).

Offerhaus L.:

De gevaren wan het gebruik van geneesmiddelen bij bejaarden - implicaties van de verwnderde farmacokinetiek en farmacodynamiek voor een juiste indicat tiestelling en dosering.

Ned. T. Geneesk. 121, pag. 1660-1661. (1977).

v. Oosterwijk - Bruyn J.:

De veranderde leeftijdsopbouw van de Nederlandse bevolking.

Ned. T. Geneesk. 121. pag, 1634-1638, (1977).

Pedersen $\mathrm{H}$ :

The Problem of the geriatric amputee.

Pirogoff N:

Artific. Limbs. 12 Autumn. (1968).

Osteoplastic elongation of the bones of the lower leg in conjunction with release of the foot from the ankle joint.

J. Military Med. St. Petersberg. 63:83. (1854).

v. ProosdijC.:

Normale en werstoorde bewegingspatronen in relatie tot leeftijd en ziekte.

Ned. T. Geneesk. 121. pag. 1677-1680. (1977). 
P.O.W.L.:

Provincialal orgaian Welzijnsbevordering Limburg. Roermond.

P.O.W.L. Bericht, nowember 1978.

Querido A.:

Ceneeskunst in Transcendentie.

Stenfert Kroese. Leiden. (1952)

Reiner E., Kathofer R.:

Bericht uber die Versorgung eines Kniegelenkexartikulierten mit der Kniegelenkkonstruklion des Forschungsinstitutes für Orthopaddie Technik. F.I.O.T. Wien.

Reyes R:

Orthopädie Techniek 5. pag. 81-82. (1975).

Eldery Patients with lower extremity amputations. Three years study in a rehabilitation setting.

Arch. Phys. Med. Rehabilitation. Vol. 58. pag. 116-123. (1977).

te Riele H:

Basisgedachten van het begrip "Revalidatie".

Metamedica 5. pag. 94-98. (1974).

Romme M.:

Medisch Maatschappelijk Werk in de intramurale zorg.

Metamedica 56. pag. 46-53. (1977).

Rouwens T:

Amputaties van het bovenbeen.

Roux J.:

Ned. T. Geneesk. 122. pag. 1.012-1015. (1978).

Annales de Therapeutique. Paris (1846), geciteerd door Farabeuf in Precis de manuel operatoire.

G. Masson ed. Paris. (1881).

Sarmiento A., McCollough N.:

The Orthopaedist and Rehabilitation.

Clinical Orthopaedics 41. pag. 111-115. (1965).

Sarmiento A., May B., Sinclair W., Newton C., MeCollough, Williams E.:

Lower extremity amputations.

Clinical Orthopaedics. 68. pag. 22-31. (1970).

Sarmiento A.:

a modified Surgical-Prosthetic approach to the Syme's Amputation. a follow-up report.

Clinical Orthopaedics. 85. pag. 11-15. (1972).

Schreinemachers L., Mever I., Kuypers P.:

Enige kanttekeningen bij de amputatio femoris.

Ned. T. Geneesk. I15. pag. 1991-1993. (1971).

Schreuder J.:

Revalidatie en geriatrie in het algemeen ziekenhuis.

Ned. T. Geneesk. 112. pag. 1787-1790. (1968).

Scottish Home and Health Department:

The future of the artificial Limb Service in Scotland.

Edinburgh. Her Majesty"s stationary office. (1970).

Sipsinat D.:

Oorzaken van geestelijk dysfunctioneren op oudere leeftijd.

Ned. T. Geneesk. 121. pag. 1666-1669. (1977).

Spittler A., Brennan J., Payne J.:

Syme amputation performed in two stages.

J. Bone and Joint Surg. Vol. 36A " pag. 37-42. (1954).

Strandness D. E., Bell J. W.

Peripheral vascular disease: diagnosis and objective evaluation using a mercury strain gatuge.

Ann. Surg. 161. pag. 3-35. (1965).

Strinivasan $\mathrm{H}$.:

Syme's anputation in insensitive feet.

J. Bone and Joint Surg. Vol. 55A. pag. 558-562. (1973). 
Syme J:

On amputation at the ankle joint.

London and Edinburgh Monthly Journal of Medical Science. Vol. 3. page 93 (1843). Syme J.:

Amputation at the ankle joint.

Syme J.:

London and Edinburgh Monthly Journal of Medical Science. Vol 4. pag 647 , (1848),

Amputation at the ankle joint.

Syme J.:

Clinical Orthopaedics and Related Research. 37. pag. 8-10. (1964).

Contributions to the pathology and practice of surgery.

Taks A.: Murray \& Gibb. Edinburgh. (1848).

De femoro-popliteale bypass en samengestelde ingrepen. Diss. 1978.

Drukkerij Missiehuis Sittard.

v. d. Tempel W.:

Prothesevoorziening van geamputeerde patiënten met vaataandoeningen.

Thomas L:

Protech Groningen (1978).

Verschuiving van de zorg.

Metamedica 56. pag. 92-97. (1977).

Tietze A.:

Über den Architektonischen Aufbau des Bindegewebes in der Menschlichen Fussohle.

Beitrage zur Klin. Chir. 123. pag, 493. (1921).

Treue W.:

Mit den Augen ïhrer Leibärzte.

Droste Verlag. Düsseldorf. (1956).

Vasconcelos E.

Modern methods of amputation. Department of War Medicine.

The Philosophical Library. New York. (1945).

Vaucher J.:

Bestimmung der Amputationshöhe durch Arteriografie, Druckmessung und Auskultation nach Doppler, elektronischer Oszillometrie und Isotopen Scanning.

Der Orthopäde. 7. pag, 86-90. (1978).

Vitalie M., Redhead R.:

The modem concept of the general management of amputee rehabilitation including immediate post-operative fitting.

Ann. Roy. Coll. Surg. Engl. 40. pag. 251. (1967).

V.R.I.N.:

Het Revalidatiecentrum. Een proeve van een typologie van het revalidatiecentrum als instituut voor de gezondheidszorg.

Secretariaat V.R.I.N. Utrecht, (1975).

Wagner $F$ :

Amputation of the foot and ankle.

Waters R.

Clinical Orthopaedics. 122. pag. 62-69. (1977).

Energy cost of walking of amputees: the influence of level of amputation.

J. Bone and Joint Surg. Vol 58A. pag. 42-45. (1976).

Weiner D.:

Prosthetic stimulation of femoral growth following knee disarticulation.

Excerpta Medica. Vol 21. pag. 267. (1978).

Weiss M.:

The results of the electromyografic tests carried out on patients after amputations.

Prosthetics International. Copenhagen. pag. 35-39. (1960).

Weiss M.

Myoplastic amputation, instant prosthesis ambulation using physiological biochemical conditions.

Konstancin institute of the Warsaw School of Medicine. (1967). 
Weiss M. Wirskil $J_{\text {.: }}$

Neurophysiology of the amputees.

1. Internationaler Kongress füi Prothesentechnik unid funktionelle Rehabilitation. Wien, Osterreich. Vol. 1. pag. 47-57. (1973).

Weiss M.:

Myoplastic Amputation, Immediate Prosithesis and early Ambulation.

U.S. Government Printing office, Washington D.C. (1971). 


\section{VERANTW OORDING VAN DE AFBEELDINGEN}

Fig. 2, 6, 49 en 50:

Dederich $\mathbb{R}_{*}$ : Amputationen der unteren Extremität.

Georg Thieme Verlag Stuttgart. (1970)

Fig. 3 en 9:

Jheronimus Bosch: Stichting Jeroen Biosch Expositie, 's Hertogenbosch, Nederland. (1967)

Fig. 5:

Treue W.: Mit den Augen ihrer Leibärtzte.

Droste Verlag Düsseldorf. (1956)

Tabel 1 en 2 en fig. 8 :

C.B.S.: De toekomstige demografische ontwikkeling in Nederland na 1975.

's Gravenhage, Staatsuitgeverij. (1976)

Tabel 3, fig. 10, 14, 51 en 52:

Baumgartner R.: Amputationen und Prothesenversorgung beim Kind.

Ferdinand Enke Verlag Stuttgart. (1977)

Fig. $22,24,25,30,31,32,33,35$ en 48 :

Harris R.: The history and development of Syme"s amputation. Selected articles from artificial limbs.

Robert Krieger Publishing Co.ine. Huntington N.Y. (1970)

Fig. 23, 26, 27, 28 en 29 :

Neff G.: Die modificierten Stumfformen nach Chopart, Pirogoff und Syme.

Orthopädie Techniek 1. (1977)

Fig. 34:

Netter F.: Amputation of the lower extremity.

Ciba Pharmaceutical Company. (1964)

Fig. 47 :

Sarmiento A.: A modified surgical - prosthetic approach to the Syme"s Amputation.

Clinical Orthopaedics 85. (1972)

Fig. 54:

Bar A.: Pneumatic sypracond ylar suspension for knee - disarticulation prostheses.

Orthotics and Prosthetics. Vol. 31. (1977)

Tabel 40 en 41:

Provinciaal Orgaan Welzijnsbevordering Limburg.

Roermond. (1978)

De: overige afbeeldingen, weergegeven in figuren, grafieken en tabellen, zijn afkomstig wan de anteur. 



\section{CURRICULUM VITAE.}

M.G.N. Poulssen, geboren 8-8-1932 te Geleen, behaalde in 1951 het Gymnasium-bèta diploma aan het St. Joseph College te Sittard. Vanaf 1953 studeerde hij medicijnen aan de R.K. Universiteit te Nijmegen; in 1961 werd het artsexamen afgellegd. Ruim 2 jaar was hij daarna werkzaam als militair arts op de vliegbasis. Volkel voor het vervullen van de militaire dienstplicht. In 1964 begon zijn opleiding tot chirurg in het ziekenhuis St. Annadal te Maastricht onder leiding van dr. H.A.J. Lemmens. Een zintuiglijke handicap maakte een algemene chirurgische praktijk onmogelijk.

Vanaf 1972 is hij werkzaam als afdelingshoofd in het Revalidatie-Centrum "Hoensbroeck", een onderdeel van de Lucas Stichting voor Revalidatie.

Naast de behandeling van geamputeerden en patiënten met diverse andere afwijkingen van het bewegingsapparaat, werd vooral de aandacht gericht op de organisatie van de zorg voor geamputeerden in de regio, met name met betrekking tot het eerste en tweede echelon van de gezondheidszorg.

Verantwoording afleggen van deze werkzaamheden leidde tot het schrijven van deze dissertatie. 